Prepared for the U.S. Department of Energy

under Contract DE-AC05-76RL01830

\title{
Hydrogeologic Model for the Gable Gap Area, Hanford Site
}

BN Bjornstad

PD Thorne

BA Williams

GV Last

September 2010
GS Thomas

MD Thompson

JL Ludwig

DC Lanigan 


\section{DISCIAAIMER}

This report was prepared as an account of work sponsored by an agency of the United States Government. Neither the United States Government nor any agency thereof, nor Battelle Memorial Institute, nor any of their employees, makes any warranty, express or implied, or assumes any legal liability or responsibility for the accuracy, completeness, or usefulness of any information, apparatus, product, or process disclosed, or represents that its use would not infringe privately owned rights. Reference herein to any specific commercial product, process, or service by trade name, trademark, manufacturer, or otherwise does not necessarily constitute or imply its endorsement, recommendation, or favoring by the United States Government or any agency thereof, or Battelle Memorial Institute. The views and opinions of authors expressed herein do not necessarily state or rellect those of the United States Government or any agency thereof.

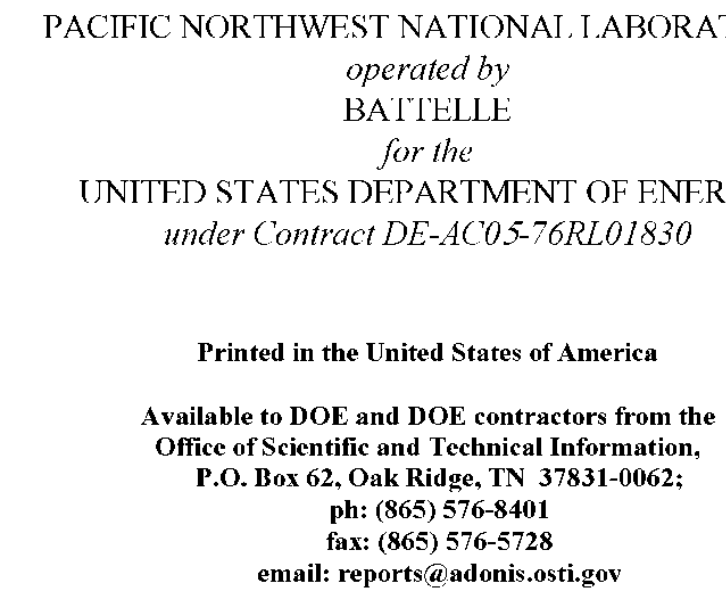

Available to the public from the National Technical Information Service, U.S. Department of Commerce, 5285 Port Royal Rd., Springfield, VA 22161 ph: (800) 553-6847 fax: (703) 605-6900 email: orders@ntis.fedworld.gov online ordering: http://www.ntis.gov/ordering.htm 


\title{
Hydrogeologic Model for the Gable Gap Area, Hanford Site
}

\author{
BN Bjornstad \\ PD Thorne \\ BA Williams ${ }^{1}$ \\ GV Last \\ GS Thomas ${ }^{1}$ \\ MD Thompson ${ }^{2}$ \\ JL Ludwig $^{3}$ \\ DC Lanigan \\ ${ }^{1}$ CH2M HILL Plateau Remediation Company \\ ${ }^{2}$ MDT Associates \\ ${ }^{3}$ Intera Inc.
}

September 2010

Prepared for

the U.S. Department of Energy

under Contract DE-AC05-76RL01830

Pacific Northwest National Laboratory

Richland, Washington 99352 


\section{Executive Summary}

Gable Gap is a structural and topographic depression between Gable Mountain and Gable Butte within the central Hanford Site. It has a long and complex geologic history, which includes tectonic uplift synchronous with erosional downcutting associated with the ancestral Columbia River during both Ringold and Cold Creek time intervals, and by the later Ice Age (mostly glacial Lake Missoula) floods. The gap was subsequently partially backfilled by mostly coarse-grained, Ice Age flood deposits (Hanford formation). Erosional remnants of both the Ringold Formation and Cold Creek unit locally underlie the high-energy flood deposits. A large window exists in the gap where confined basalt aquifers are in contact with the unconfined suprabasalt aquifer.

Multiple paleochannels, of both Hanford and Ringold formation age, were eroded into the deformed basalt bedrock across Gable Gap. Groundwater from the Central Plateau presently moves through Gable Gap via one or more of these paleochannels. As groundwater levels continue to decline in the region, most groundwater flow may eventually be diverted from flowing through Gable Gap. However, the base of the aquifer is poorly constrained in the area of the basalt divide; other unidentified buried channels may exist across the divide that could provide flow paths across Gable Gap for an indefinitely longer period.

An updated hydrogeologic conceptual model of the Gable Gap area is presented in this report. This model is based on analysis of the old and new geologic, hydrologic, and groundwater chemistry data needed to understand groundwater and contaminant movement through the Gap. Because of the sparse and uneven distribution of boreholes in portions of Gable Gap, uncertainties in the model still exist. Therefore, the model presented herein is subject to refinement with the inclusion of more data in the future. 


\section{Acknowledgments}

We appreciate the support of CH2M HILL Plateau Remediation Company and members of the Central Plateau Hydrogeology Working Group, including Pat Cabbage and Steve Airhart of Freestone Environmental Services, and Steve Miller. We also appreciate the helpful reviews of Virginia Rohay, John McDonald, Frank Spane, and Mickie Chamness. Lastly, we thank Steve Reidel and Karl Fecht for sharing their extensive knowledge on the structure and top of basalt within Gable Gap. 


\section{Acronyms and Abbreviations}

$\begin{array}{ll}\text { BP-5 } & \text { BP-5 Groundwater Operable Unit } \\ \text { BWIP } & \text { Basalt Waste Isolation Project } \\ \text { CCU } & \text { Cold Creek unit } \\ \text { CCUc } & \text { Cold Creek unit - caliche } \\ \text { CCUg } & \text { Cold Creek unit - gravel-dominated } \\ \text { CCUz } & \text { Cold Creek unit - silt-dominated } \\ \text { CRBG } & \text { Columbia River Basalt Group } \\ \text { H1 } & \text { Hanford formation unit 1 } \\ \text { H2 } & \text { Hanford formation unit 2 } \\ \text { H3 } & \text { Hanford formation unit 3 } \\ \text { HEIS } & \text { Hanford Environmental Information System } \\ \text { YFB } & \text { Yakima Fold Belt }\end{array}$




\section{Contents}

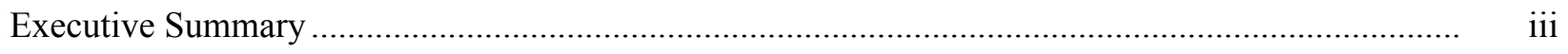

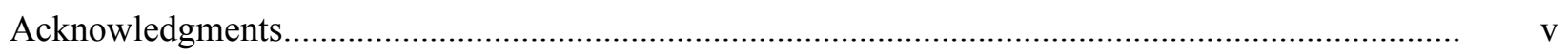

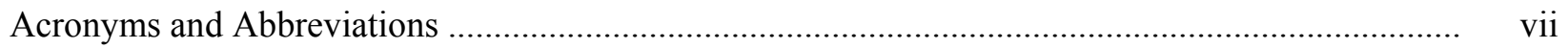

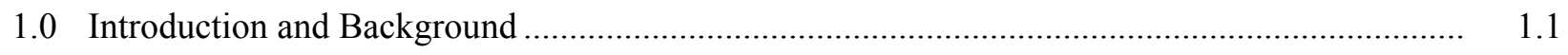

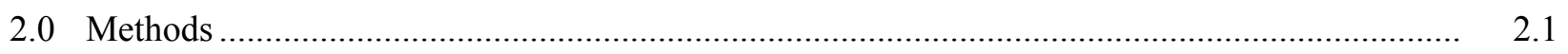

2.1 Borehole Data Used to Differentiate Lithologic/Stratigraphic Units ................................. 2.1

2.2 Quality Ranking of Boreholes................................................................................. 2.7

2.3 Development of Conceptual Hydrogeologic Model .................................................... 2.8

2.4 Integration of Geophysics Data ................................................................................. 2.8

3.0 Regional Geologic Setting ...................................................................................... 3.1

3.1 Columbia River Basalt Group and Ellensburg Formation ........................................... 3.2

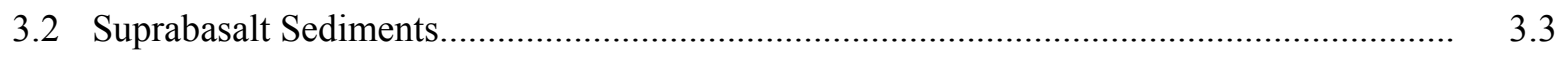

3.2.1 Ringold Formation ................................................................................. 3.3

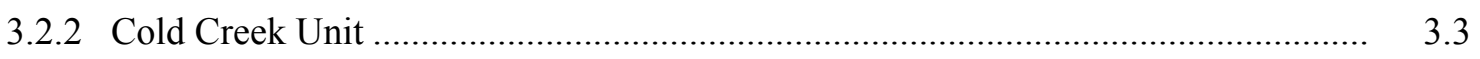

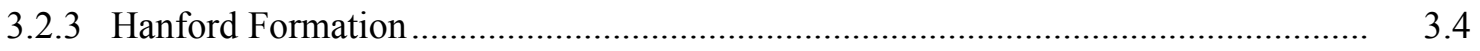

$4.0 \quad$ Stratigraphy and Lithology of Gable Gap ....................................................................... 4.1

4.1 Columbia River Basalt Group and Interbedded Sediments of the Ellensburg

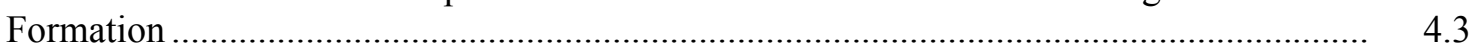

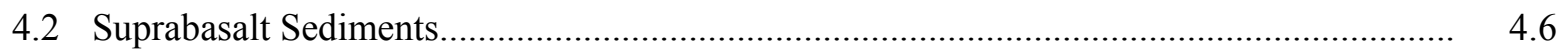

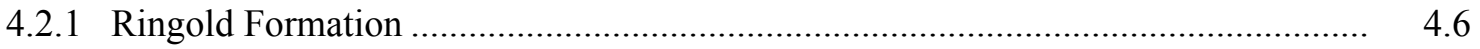

4.2.2 Cold Creek Unit ............................................................................... 4.7

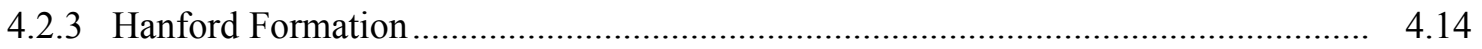

4.2.4 Holocene Deposits.................................................................................. 4.17

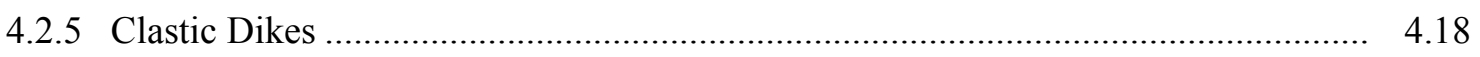

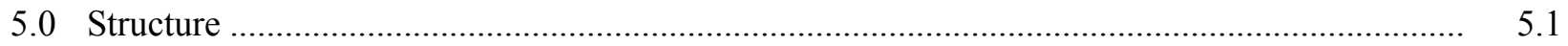

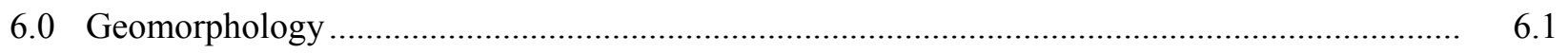

6.1 Late-Pleistocene Flood Channels and Bars ................................................................ 6.1

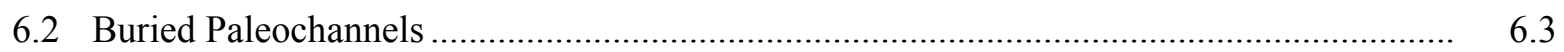

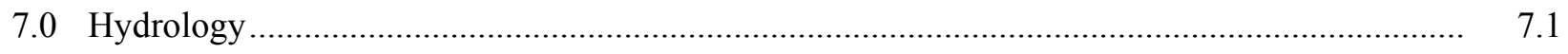

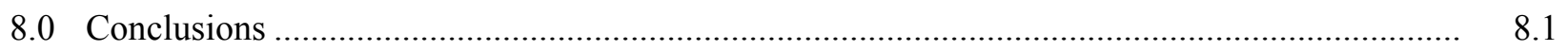

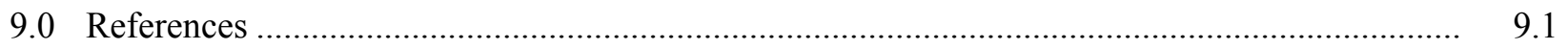

Appendix A - Hydrogeologic Cross Sections ........................................................................... A.1

Appendix B - Structure-Contour Maps Based on EarthVision ${ }^{\circledR}$ Model ........................................... B. 1

Appendix C - Isopach Maps Based on EarthVision ${ }^{\circledR}$ Model .................................................... C.1

Appendix D - Three-dimensional EarthVision ${ }^{\circledR}$ Model ........................................................... D. 1

Appendix E - Borehole Information and Tops of Stratigraphic Unit Contacts ................................ E. 1 


\section{Figures}

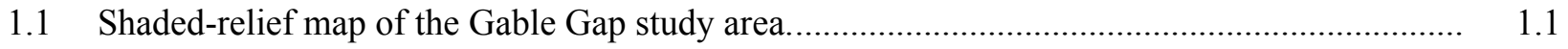

$2.1 \quad$ Borehole index map. .............................................................................................. 2.1

2.2 Example summary log for Gable Gap well 699-48-50B illustrating the various parameters

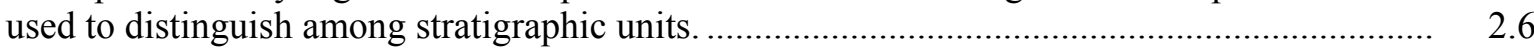

2.3 Quality ranking comparison of $\sim 150$ boreholes in the Gable Gap study area........................... 2.7

2.4 Locations of five hydrogeologic cross sections within the study area .................................. 2.9

2.5 Latest top of basalt interpretation based on borehole and seismic-reflection-survey data in the Gable Gap area.

3.1 Regional stratigraphy for the Pasco Basin and Hanford Site. Modified after DOE/RL (2010).

3.2 Stratigraphic nomenclature for the Columbia River Basalt Group.

3.3 Thickness and distribution of cataclysmic flood deposits (i.e., Hanford formation) within the central Pasco Basin ....

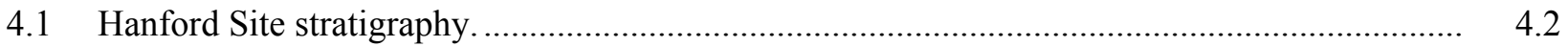

4.2 Stratigraphy in the vicinity of Gable Gap ........................................................................... 4.4

4.3 Example hydrogeologic cross section (A-A') for Gable Gap ................................................ 4.5

4.4 Erosional remnants of the Ringold Formation in Gable Gap well 699-48-50B (C5196).......... 4.6

4.5 Gravel-dominated facies of the Cold Creek unit (CCUg) from boreholes in the vicinity of

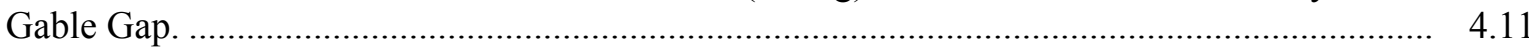

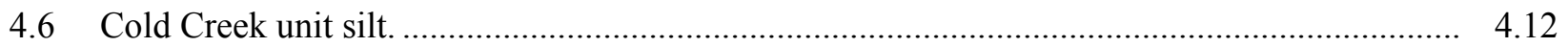

4.7 EarthVision ${ }^{\circledR}$ model showing the mound-like form of the Cold Creek silt (CCUz) subunit extending south from Gable Gap

4.8 Example of high-relief, streamlined and scarped hills of silty Palouse Formation located in the eastern Channeled Scabland.

4.9 Hanford formation $\mathrm{H} 2$ unit in 200 East Area.

4.10 Hanford formation H1 unit from the B-BX-BY Tank Farm, 200 East Area.

4.11 Outburst-flood deposits of the Hanford formation exposed along the north wall of the 218-E-12B Burial Ground located along the north flank of the Cold Creek Flood Bar

5.1 Geologic structures in the vicinity of Gable Gap.

5.2 Flood-swept, hogback ridge of western Gable Mountain, looking southeast.

6.1 EarthVision ${ }^{\circledR}$ model of the present-day surface topography within the Gable Gap study area.

6.2 Surface-geomorphic map of the Gable Gap study area..

6.3 Buried paleochannels within the Gable Gap area

6.4 Example of highly irregular topography eroded by Ice Age floods, Lower Grand Coulee, Channeled Scabland.

7.1 Location of window eroded through the upper flows of Columbia River Basalt Group within Gable Gap

7.2 Distribution of stratigraphic units encountered at the 2009 water table. 
7.3 Aquifer thickness (in meters) map in the vicinity of Gable Gap.

7.4 Selected hydrographs of Gable Gap wells open to the unconfined aquifer (Hanford formation)

7.5 Discharge history for the B Pond and the Gable Mountain Pond systems............................... 7.6

8.1 Late-Cenozoic history and evolution of paleodrainage in the vicinity of Gable Gap ................ 8.2

8.2 Ice Age floods in geologic time. The Ice Age, equivalent to the Pleistocene Epoch, lasted from 2.6 million years ago until about 15,000 years ago..........................................................

8.3 Areas of suspected groundwater flow through Gable Gap from the Central Plateau. ............... 8.5

\section{Tables}

2.1 Quality ranking of 160 boreholes, located in Figure 2.1, used in Gable Gap conceptual mode

4.1 Characteristics used to distinguish between suprabasalt stratigraphic units within Gable Gap 


\subsection{Introduction and Background}

Gable Gap refers to a topographic and structural saddle that lies between Gable Mountain and Gable Butte (Figure 1.1) in the north-central portion of the U.S. Department of Energy's Hanford Site. The Gable Gap area lies north of the Central Plateau and is superimposed on the Cold Creek Bar north of the 200 East and 200 West Areas. The Central Plateau is where much of the hazardous and nuclear liquid wastes from the Hanford Site were discharged to the subsurface through various tanks, cribs, and trenches. Groundwater beneath the 200 Areas flows east to southeast; however, some groundwater also appears to flow northwestward through Gable Gap (DOE/RL 2010). This pathway is indicated by groundwater-contaminant plumes (uranium and technetium-99) that extend northwestward from the presumed source in the 200 East Area (Serne et al. 2010). As such, Gable Gap may represent a potential flow path to the Columbia River for some groundwater contaminants on the Hanford Site.

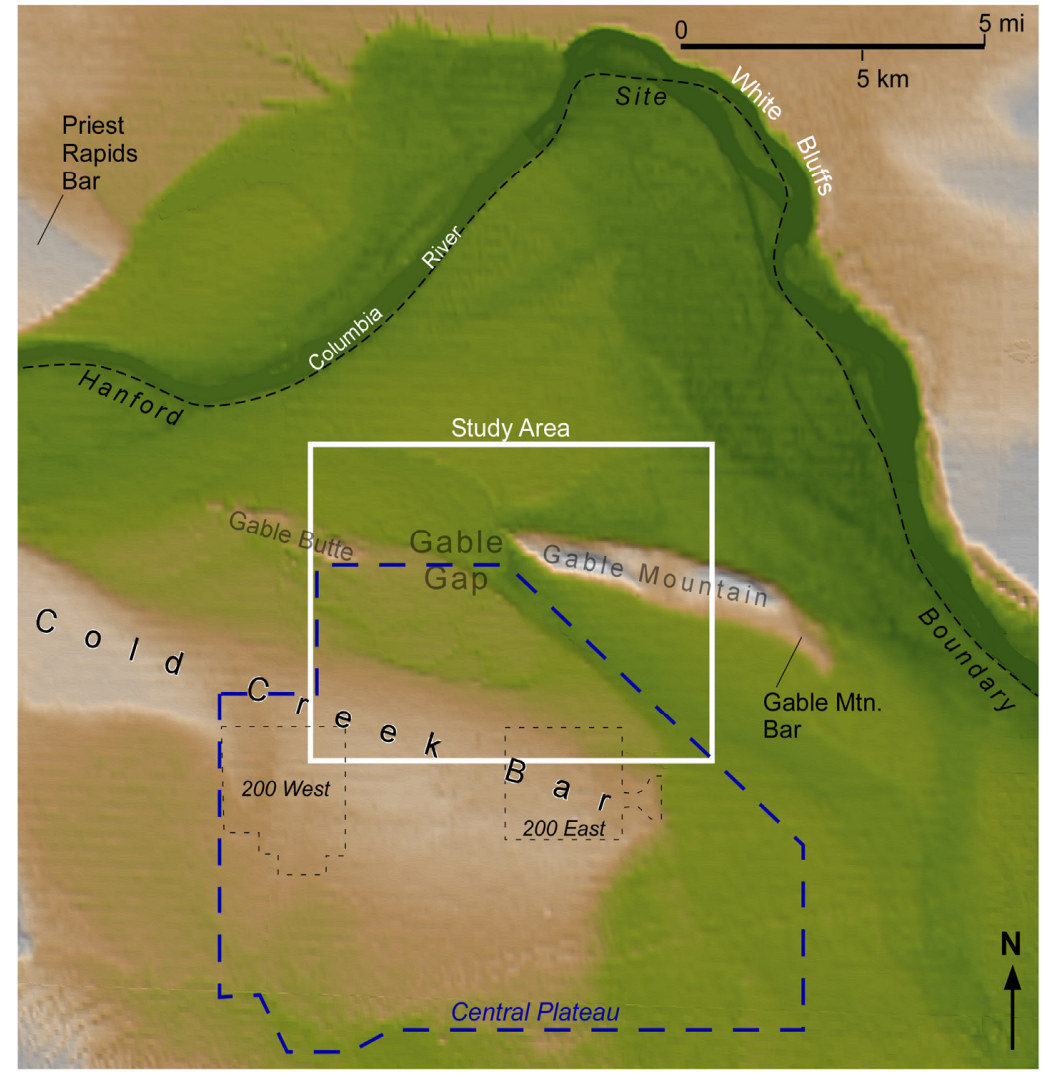

Figure 1.1. Shaded-relief map of the Gable Gap study area.

The purpose of this report is to present the latest hydrogeologic conceptual model for the area based on a comprehensive analysis of available stratigraphic, structural, geomorphic, and hydrologic information pertinent to understanding the groundwater flow and movement of contaminants within the Gable Gap region. Included are discussions of the stratigraphy and lithology of the various stratigraphic units and how these are used to interpret the geologic history of the central Pasco Basin. This information 
forms the basis for interpreting the complex erosional and tectonic history, as well as the geomorphology and hydrogeology of the Gable Gap area. Data used to support interpretations and conclusions are presented in five appendices:

- Appendix A - Five hydrogeologic cross sections

- Appendix B - EarthVision ${ }^{\circledR}-$ based structure contour maps

- Appendix C - EarthVision ${ }^{\circledR}$-based isopach maps.

- Appendix D - Three-dimensional EarthVision ${ }^{\circledR}$ Model

- Appendix E - Borehole Information and Tops of Stratigraphic Unit Contacts

Numerous studies describing the hydrogeology of the area create the foundation from which the conceptual model has evolved (e.g., Tallman et al. 1979; DOE 1988; Last et al. 1989; Hoffman et al. 1992; WHC 1992; Lindsey et al. 1992; Lindsey 1995; Williams et al. 2000; Wood et al. 2000; Reidel and Chamness 2007; and Serne et al. 2010). Previous investigations focusing more specifically on Gable Gap include surface geologic mapping (Fecht 1978; Myers et al. 1979), subsurface geophysical investigations (Holmes and Mitchell 1981; Ault 1981, Repasky et al. 2009), and aquifer intercommunication studies between the unconfined aquifer and the Rattlesnake Ridge interbed (Strait and Moore 1982; Graham et al. 1984; Jensen 1987; Spane and Webber 1995). All these previous studies established the foundation for the conceptual hydrogeologic model presented in this report. 


\subsection{Methods}

The present study included a re-evaluation of borehole data from $\sim 160$ boreholes drilled in the vicinity of Gable Gap since 1944 (Figure 2.1, Table 2.1), including a number of new borings drilled over the last few years. Data analyzed include all available drillers', geologists', and geophysical logs; archived sediment samples; and photographs, as well as field and laboratory characterization data. Aquifer-test results were also considered (Thorne et al. 2006) and in some cases were used in identifying the geologic formation exposed along the open intervals of monitoring wells. In addition, surface geophysical surveys were integrated to better define the surface of the top of basalt between boreholes. The uppermost basalt flow encountered in boreholes was interpreted based on chemical signatures for the different basalt flows using X-ray fluorescence reported in Graham et al. (1984) and Reidel and Fecht (unpublished data).

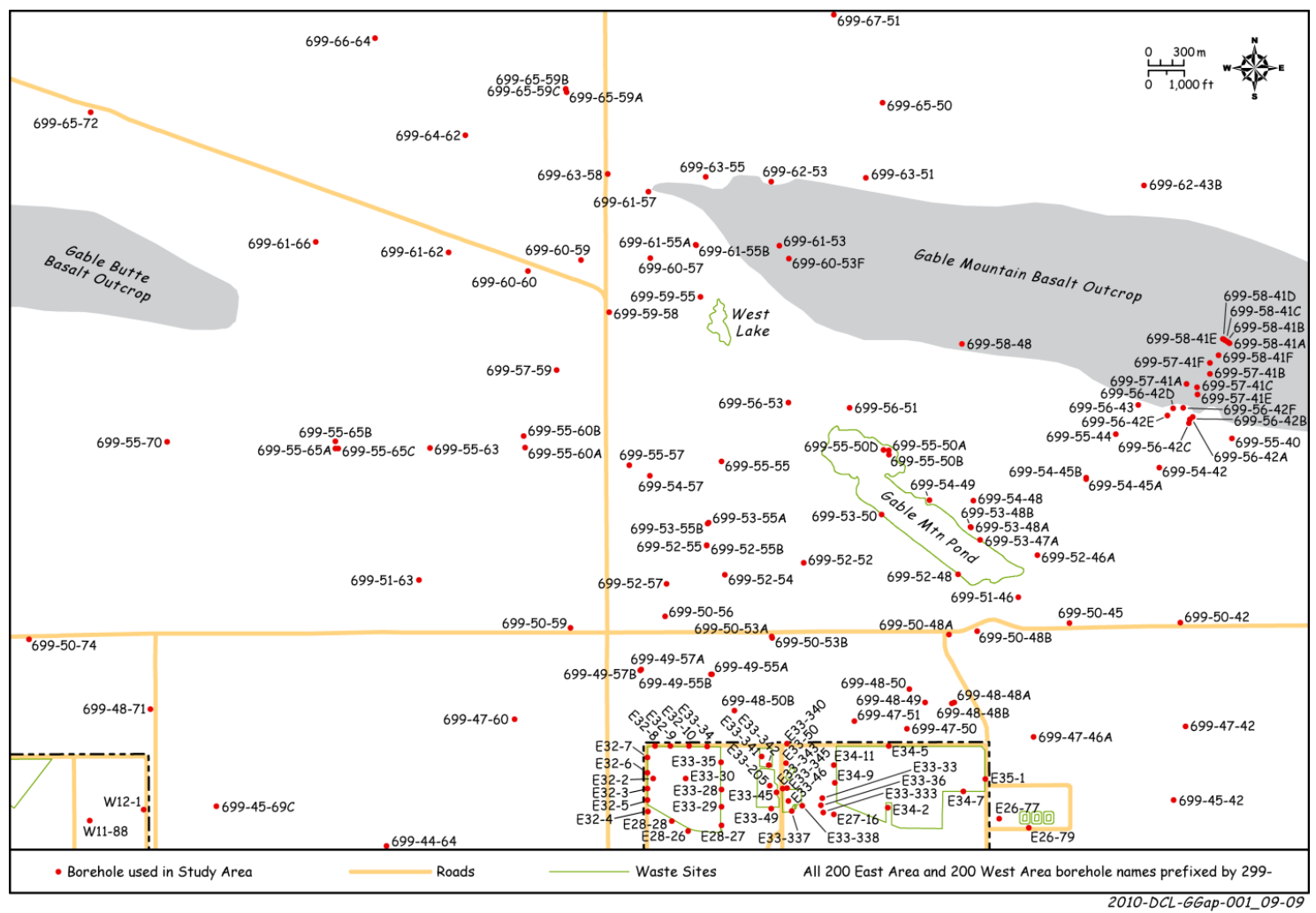

Figure 2.1. Borehole index map. Located are most of the $\sim 160$ boreholes used to construct the conceptual hydrogeologic model for the Gable Gap study area.

\subsection{Borehole Data Used to Differentiate Lithologic/Stratigraphic Units}

Common types of borehole data available to discriminate between lithologic and stratigraphic units include geologists' descriptions, drillers' descriptions, as-built diagrams, grain-size analyses, geophysical logs (i.e., natural gamma, spectral gamma, and/or neutron-moisture), sediment photographs, as well as drilling information (e.g., drill rate, ease of driving casing, open hole, heaving, etc.). These data were used to determine the lithologic and stratigraphic units present in each of the boreholes analyzed in the study area. Most boreholes are lacking in one or more of these datasets; many are lacking in all but one or two. 
Table 2.1. Quality ranking of 160 boreholes, located in Figure 2.1, used in Gable Gap conceptual model.

\begin{tabular}{|c|c|c|c|c|c|c|c|c|c|}
\hline Well Name & Well ID & $\begin{array}{l}\text { Total Depth } \\
\text { (ft) }\end{array}$ & Completed & $\begin{array}{c}\text { Data Quality } \\
\text { Ranking^^}\end{array}$ & Well Name & Well ID & $\begin{array}{l}\text { Total Depth } \\
\text { (ft) }\end{array}$ & Completed & $\begin{array}{c}\text { Data Quality } \\
\text { Ranking^^}\end{array}$ \\
\hline 299-E26-77 & C6455 & 224.8 & 2008 & 1 & 299-E33-205 & C5989 & 270.6 & 2008 & 1 \\
\hline 299-E26-79 & C6826 & 224.8 & 2008 & 1 & 299-E33-333 & B8079 & 254 & 1998 & 2 \\
\hline 299-E27-16 & A4814 & 269 & 1990 & 3 & 299-E33-337 & C3390 & 286 & 2001 & 2 \\
\hline 299-E28-26 & A4822 & 328.5 & 1987 & 2 & 299-E33-338 & C3391 & 275.8 & 2001 & 1 \\
\hline 299-E28-27 & A4823 & 301.5 & 1987 & 3 & 299-E33-340 & C5853 & 325.7 & 2008 & 1 \\
\hline 299-E28-28 & A4824 & 296 & 1990 & 3 & 299-E33-341 & C5856 & 237 & 2008 & 1 \\
\hline 299-E32-2 & A4830 & 289.2 & 1987 & 2 & 299-E33-342 & C5857 & 245.5 & 2008 & 1 \\
\hline 299-E32-3 & A4831 & 304 & 1987 & 2 & 299-E33-343 & C5858 & 263.8 & 2008 & 1 \\
\hline 299-E32-4 & A4832 & 311 & 1987 & 2 & 299-E33-345 & C6226 & 263.8 & 2008 & 1 \\
\hline 299-E32-5 & A4833 & 293.6 & 1989 & 2 & 299-E34-2 & A4877 & 241.5 & 1987 & 2 \\
\hline 299-E32-6 & A4834 & 278.8 & 1991 & 3 & 299-E34-5 & A4880 & 190.5 & 1987 & 2 \\
\hline 299-E32-7 & A4835 & 273.8 & 1991 & 2 & 299-E34-7 & A4882 & 205.5 & 1989 & 3 \\
\hline 299-E32-8 & A4836 & 256.7 & 1991 & 2 & 299-E34-9 & A4884 & 234.5 & 1991 & 2 \\
\hline 299-E32-9 & A4837 & 254.6 & 1991 & 2 & 299-E34-11 & A4876 & 219.3 & 1991 & 2 \\
\hline 299-E32-10 & A5432 & 245.8 & 1992 & 2 & 299-E35-1 & A4885 & 193.8 & 1989 & 2 \\
\hline 299-E33-28 & A4852 & 278.3 & 1987 & 3 & 299-W11-88 & C5572 & 490.2 & 2008 & 1 \\
\hline 299-E33-29 & A4853 & 290 & 1987 & 2 & 299-W12-1 & A4912 & 314 & 1956 & 4 \\
\hline 299-E33-30 & A4855 & 280.1 & 1987 & 2 & $699-44-64$ & A5188 & 452 & 1960 & 3 \\
\hline 299-E33-33 & A4858 & 252 & 1989 & 2 & $699-45-42$ & A5195 & 195 & 1948 & 4 \\
\hline 299-E33-34 & A4859 & 240 & 1990 & 2 & $699-45-69 C$ & C5574 & 455 & 2007 & 2 \\
\hline 299-E33-35 & A4860 & 250 & 1990 & 3 & $699-47-42$ & A8749 & 1971 & 1979 & 5 \\
\hline 299-E33-36 & A4861 & 264 & 1990 & 2 & $699-47-46 A$ & A5200 & 207 & 1961 & 3 \\
\hline 299-E33-45 & C3269 & 261 & 2001 & 1 & $699-47-50$ & A5201 & 295 & 1980 & 4 \\
\hline 299-E33-46 & C3360 & 264.4 & 2001 & 1 & $699-47-51$ & A8752 & 167 & 1959 & 4 \\
\hline 299-E33-49 & C4261 & 288.8 & 2004 & 1 & $699-47-60$ & A5202 & 287 & 1948 & 3 \\
\hline \multirow[t]{4}{*}{ 299-E33-50 } & C5195 & 381 & 2006 & 1 & $699-48-48 \mathrm{~A}$ & A8768 & 5661 & 1972 & 5 \\
\hline & & & & & $699-48-48 B$ & A8769 & 3374 & 1977 & 4 \\
\hline & & & & & $699-48-49$ & A 8770 & -- & -- & 5 \\
\hline & & & & & $699-48-50$ & A5212 & 197 & 1990 & 25 \\
\hline
\end{tabular}

$\wedge 1=$ best, $5=$ worst. 
Table 2.1. (contd)

\begin{tabular}{|c|c|c|c|c|c|c|c|c|c|}
\hline Well Name & Well ID & $\begin{array}{l}\text { Total Depth } \\
\text { (ft) }\end{array}$ & Completed & $\begin{array}{l}\text { Data Quality } \\
\text { Ranking^ }\end{array}$ & Well Name & Well ID & $\begin{array}{l}\text { Total Depth } \\
(\mathrm{ft})\end{array}$ & Completed & $\begin{array}{c}\text { Data Quality } \\
\text { Ranking^ }\end{array}$ \\
\hline 699-48-50B & C5196 & 215.2 & 2006 & 1 & $699-52-57$ & A5237 & 165.5 & 1991 & 2 \\
\hline $699-48-71$ & A5214 & 305 & 1956 & 4 & $699-53-47 \mathrm{~A}$ & A5239 & 41.5 & 1966 & 4 \\
\hline $699-49-55 \mathrm{~A}$ & A5217 & 149 & 1961 & 4 & $699-53-48 \mathrm{~A}$ & A5241 & 53 & 1984 & 4 \\
\hline $699-49-55 B$ & A5218 & 227 & 1982 & 4 & $699-53-48 B$ & A5242 & 44 & 1984 & 4 \\
\hline $699-49-57 \mathrm{~A}$ & A5219 & 168 & 1956 & 3 & $699-53-50$ & A5243 & 194 & 1980 & 3 \\
\hline 699-49-57B & A5220 & 230.4 & 1990 & 2 & $699-53-55 A$ & A5244 & 455 & 1961 & 4 \\
\hline 699-49-71 & A9918 & 30 & 1993 & 5 & $699-53-55 B$ & A5245 & 252 & 1975 & 4 \\
\hline $699-50-42$ & A5224 & 125 & 1955 & 3 & $699-54-42$ & A5250 & 210 & 1948 & 4 \\
\hline $699-50-45$ & A5225 & 178 & 1980 & 3 & $699-54-45 \mathrm{~A}$ & A5251 & 105 & 1971 & 3 \\
\hline $699-50-48 \mathrm{~A}$ & A8812 & 1,165 & $1955 / 1969$ & 3 & $699-54-45 B$ & A8862 & 314 & 1980 & 4 \\
\hline 699-50-48B & A5226 & 250 & 1980 & 3 & $699-54-48$ & A5252 & 101 & 1984 & 4 \\
\hline $699-50-53 \mathrm{~A}$ & A5227 & 185 & 1955 & 3 & $699-54-49$ & A8863 & 62 & 1984 & 3 \\
\hline $699-50-53 B$ & A5228 & 225 & 1990 & 2 & $699-54-57$ & A5253 & 321 & 1955,1982 & 3 \\
\hline $699-50-56$ & C5197 & 164.1 & 2006 & 1 & $699-55-40$ & A5255 & 145 & 1971 & 4 \\
\hline $699-50-59$ & C4882 & 173.2 & 2005 & 2 & $699-55-44$ & A5256 & 160 & 1971 & 4 \\
\hline $699-50-74$ & C4697 & 338.8 & 2005 & 2 & $699-55-50 A$ & A8865 & 110 & 1948 & 3 \\
\hline $699-51-46$ & A5230 & 168 & 1980 & 4 & 699-55-50D & A8867 & 100 & 1956 & 3 \\
\hline $699-51-63$ & A5231 & 184.5 & 1956 & 3 & $699-55-55$ & A5258 & 312 & 1990 & 2 \\
\hline $699-52-46 A$ & A5234 & 225 & 1980 & 3 & $699-55-57$ & A5259 & 180 & 1975 & 3 \\
\hline $699-52-46 B$ & A8841 & 44 & 1980 & 4 & $699-55-60 A$ & A8868 & 233 & 1943 & 4 \\
\hline $699-52-48$ & A5235 & 197 & 1980 & 3 & $699-55-60 B$ & A8869 & 288 & 1944 & 4 \\
\hline $699-52-52$ & A8842 & 903 & 1974 & 3 & $699-55-63$ & A8871 & 198 & 1944 & 4 \\
\hline $699-52-54$ & A5236 & 168.6 & 1990 & 2 & $699-55-65 A$ & A8872 & 136 & 1944 & 4 \\
\hline $699-52-55$ & C5861 & 183.3 & 2007 & 1 & $699-55-65 B$ & A8873 & 146 & 1944 & 4 \\
\hline \multirow[t]{2}{*}{ 699-52-55B } & C5862 & 292 & 2008 & 1 & $699-55-65 C$ & A8874 & 146 & 1944 & 5 \\
\hline & & & & & $699-55-70$ & A5260 & 205 & 1948 & 3 \\
\hline
\end{tabular}


Table 2.1. (contd)

\begin{tabular}{|c|c|c|c|c|c|c|c|c|c|}
\hline Well Name & Well ID & $\begin{array}{c}\text { Total Depth } \\
\text { (ft) }\end{array}$ & Completed & $\begin{array}{c}\text { Data Quality } \\
\text { Ranking }\end{array}$ & Well Name & Well ID & $\begin{array}{c}\text { Total Depth } \\
\text { (ft) }\end{array}$ & Completed & $\begin{array}{c}\text { Data Quality } \\
\text { Ranking^ }\end{array}$ \\
\hline $699-56-42 \mathrm{~A}$ & A8885 & 245 & 1981 & 2 & $699-60-60$ & A5282 & 133 & 1948 & 4 \\
\hline 699-56-42B & A8886 & 250 & 1981 & 2 & $699-61-53$ & A8932 & 385 & 1978 & 3 \\
\hline $699-56-42 \mathrm{C}$ & A8887 & 354 & 1981 & 2 & $699-61-55 \mathrm{~A}$ & A8933 & 249 & 1976 & 3 \\
\hline $699-56-42 \mathrm{D}$ & A8888 & 670 & 1981 & 3 & $699-61-55 B$ & A8934 & 327 & 1976 & 5 \\
\hline $699-56-42 E$ & A8889 & 700 & 1981 & 3 & $699-61-57$ & A8935 & 589 & 1977 & 3 \\
\hline $699-56-42 F$ & A8890 & 520 & 1981 & 3 & $699-61-62$ & A5285 & 188 & 1972 & 2 \\
\hline $699-56-43$ & A5264 & 155 & 1971 & 3 & $699-61-66$ & A5286 & 225 & 1955 & 3 \\
\hline $699-56-51$ & A8891 & 105 & 1984 & 3 & $699-62-43 B$ & A8940 & 68 & 1959 & 3 \\
\hline $699-56-53$ & A5265 & 270 & 1982 & 3 & $699-62-53$ & A8953 & 456 & 1977 & 3 \\
\hline $699-57-41 \mathrm{~A}$ & A8896 & 512 & 1981 & 3 & $699-63-51$ & A5290 & 36 & 1971 & 3 \\
\hline 699-57-41B & A8897 & 461 & 1981 & 3 & $699-63-55$ & A5291 & 121 & 1972 & 3 \\
\hline $699-57-41 \mathrm{C}$ & A8898 & 430 & 1981 & 3 & $699-63-58$ & A5292 & 133 & 1972 & 3 \\
\hline $699-57-41 E$ & A8900 & 554 & 1981 & 3 & $699-64-62$ & A5296 & 116 & 1972 & 3 \\
\hline $699-57-41 \mathrm{~F}$ & A8901 & 608 & 1981 & 2 & $699-65-50$ & A5300 & 585 & 1955 & 3 \\
\hline $699-57-59$ & A5269 & 190.5 & 1980 & 2 & $699-65-59 \mathrm{~A}$ & A5301 & 200 & 1958 & 4 \\
\hline 699-58-41A & A8908 & 274 & 1980 & 2 & 699-65-59B & A8960 & 200 & 1976 & 3 \\
\hline $699-58-41 B$ & A8909 & 225 & 1980 & 2 & $699-65-59 \mathrm{C}$ & A8961 & 140 & 1976 & 3 \\
\hline $699-58-41 \mathrm{C}$ & A8910 & 130 & 1980 & 3 & $699-65-72$ & A5302 & 216 & -- & 5 \\
\hline 699-58-41D & A8911 & 79 & 1980 & 2 & 699-66-64 & A5310 & 118 & 1972 & 4 \\
\hline $699-58-41 E$ & A8912 & 390 & 1981 & 3 & $699-67-51$ & A5312 & 250 & 1961 & 4 \\
\hline $699-58-41 F$ & A8913 & 600 & 1981 & 3 & 699-69-45 & A8967 & 300 & 1961 & 3 \\
\hline $699-58-48$ & A8914 & -- & -- & 5 & $699-70-68$ & A5319 & 149 & 1954 & 3 \\
\hline $699-59-55$ & A8918 & 145 & 1976 & 5 & $699-71-52$ & A5321 & 210 & 1954 & 3 \\
\hline $699-59-58$ & A5277 & 117 & 1972 & 3 & $699-72-73$ & A5323 & 200 & 1961 & 4 \\
\hline 699-60-53B & A8922 & 160 & 1980 & 5 & $699-73-61$ & A5327 & 150 & 1962 & 3 \\
\hline $699-60-53 \mathrm{C}$ & A8923 & 150 & 1980 & 5 & & & & & \\
\hline $699-60-53 F$ & A8926 & 290 & 1980 & 5 & & & & & \\
\hline $699-60-57$ & A5280 & 155 & 1972 & 3 & & & & & \\
\hline $699-60-59$ & A5281 & 1561 & 1986 & 2 & & & & & \\
\hline
\end{tabular}


Early boreholes drilled prior to 1980 generally have only drillers' logs and uncalibrated down-hole natural gamma geophysical logs, but were routinely analyzed for grain-size analysis and sometimes calcium-carbonate $\left(\mathrm{CaCO}_{3}\right)$ content (an indication of soil development). Drillers would collect sediment samples every $5 \mathrm{ft}(1.5 \mathrm{~m})$ and record general descriptions of the drill cuttings and other observations onto drilling-summary forms. Most of the archived sediment samples from these early (pre-1980) wells were subsequently analyzed in the laboratory for grain-size distribution and $\mathrm{CaCO}_{3}$ content; these results are maintained in a database located within the Hanford Virtual Library (http://vlprod.rl.gov/vlib/app/index).

The quality of the grain-size distribution data largely depends on the drilling method used. Before the 1990s, most wells were drilled using a cable-tool drill rig. Those intervals drilled with a hard tool tend to produce more fines because of the pulverizing action of the hard-tool bit. An alternative method is the drive-barrel, which preserves much of the original grain-size distribution and is far superior in producing representative geologic samples.

Sample retrieval is sometimes difficult and often does not permit a determination of the exact depth of contacts. The gross-gamma log is useful for more accurately determining contacts and depths of finegrained layers, especially those a meter or more thick. However, thin clay and/or silt layers often go undetected on gross-gamma logs due to volume averaging. Geophysical logs (e.g., gross-gamma ray), available for most of the boreholes, are useful for identifying some-but not all-stratigraphic contacts. Geophysical logs sometimes show lithologic differences because of differing amounts of natural gamma-ray emitters (most commonly ${ }^{40} \mathrm{~K}$ ). The proportion of ${ }^{40} \mathrm{~K}$ generally increases with decreasing grain size; therefore, clay and silt generally emit more natural-gamma rays.

Another data source useful for the interpretation of the lithology is moisture content either measured directly in the laboratory on geologic samples or remotely via down-hole neutron logs (Figure 2.2). Within the vadose zone, moisture content generally increases along interfaces between materials with highly contrasting grain size. This is particularly true where high-permeability material (gravel and/or sand) overlies lower-permeability material (sand and/or silt). However, moisture may also concentrate along interfaces where a fine-grained unit overlies a coarse sand or gravel and in fine-grained units themselves due to their greater water-retention capacity.

Using neutron-moisture logs, in combination with gross-gamma logs, further aids in the lithologic interpretation. For example, a sudden moderate increase in gamma-ray activity coincident with an increase in moisture may be indicative of a fine-grained bed. An increase in moisture without an increase in the gross-gamma log may signify a sedimentary interface without the presence of a measurable, lesspermeable fine-grained layer.

Most recent boreholes drilled after 1980 have overall better data (geologic descriptions recorded by field geologists, and calibrated geophysical logs) but generally lack any quantitative granulometric (grain size) information. Beginning in the mid-1980s samples were no longer routinely analyzed in the laboratory. Therefore, quantitative grain-size distribution and $\mathrm{CaCO}_{3}$ data are not available for most boreholes drilled since the mid-1980s; these parameters are provided, qualitatively, in geologists' logs. 


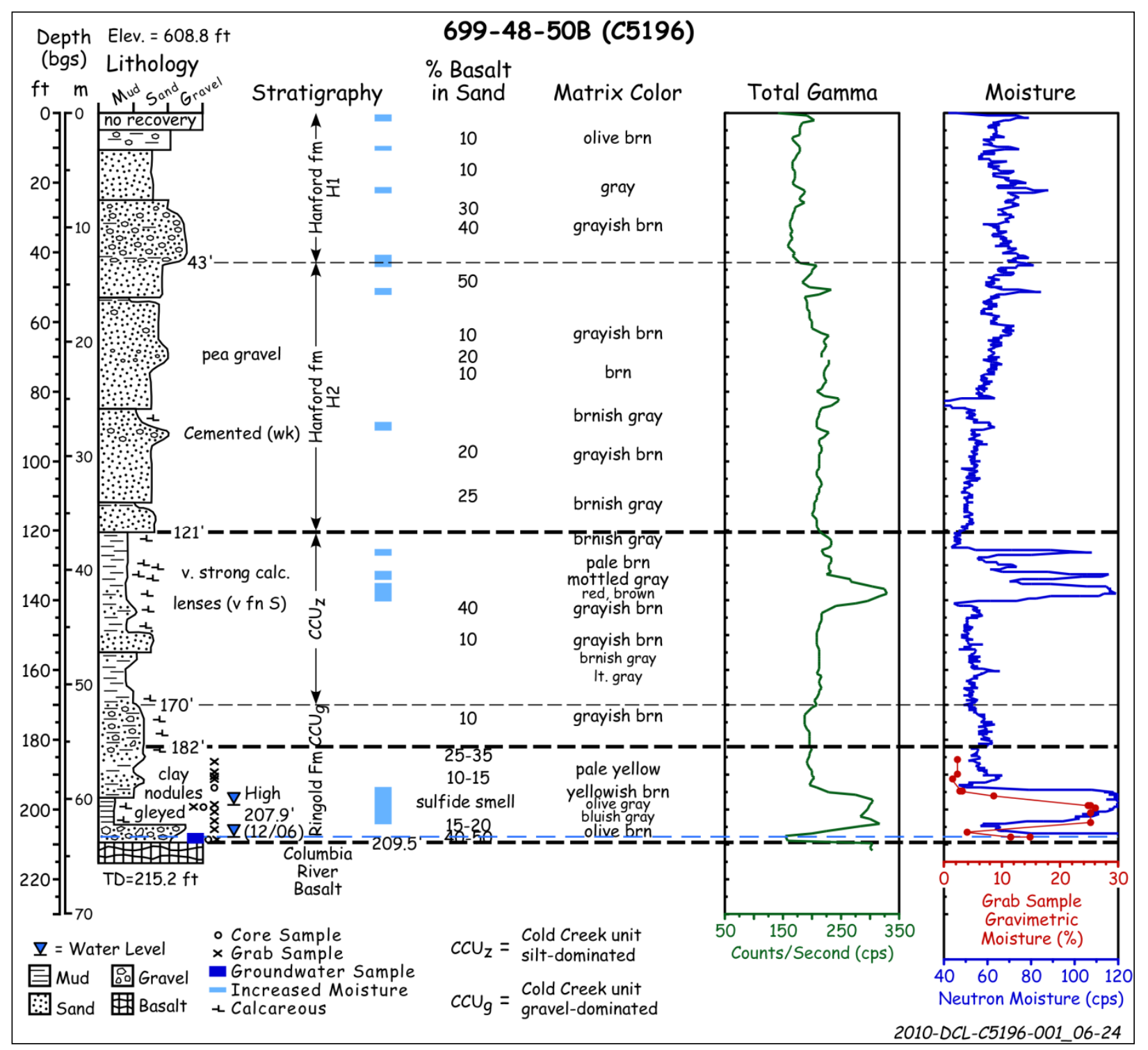

Figure 2.2. Example summary log for Gable Gap well 699-48-50B illustrating the various parameters used to distinguish among stratigraphic units.

Prior to the 1980s, many holes were at least partially drilled via the hard-tool (cable tool) method, which tended to pulverize sediment samples, especially those with high gravel content. Pulverization during drilling has the tendency to skew estimates of grain size and lithology by reducing the size of the coarse (gravel) sedimentary particles and artificially generating more fines. After 1980, there was an increased emphasis on collecting samples via the cable-tooled, core barrel (drive barrel) method, which provided samples that were less fragmented and more lithologically representative of the formation.

Since 2002, a small number of boreholes in the BP-5/Gable Gap area were characterized by collecting nearly continuous, intact sediment core via split-spoon, drive barrel, or direct-push methods. These core samples were described in detail within the laboratory to more accurately evaluate the types and vertical distribution of contaminants within the vadose zone (Brown et al. 2007; Lindenmeier et al. 2002, 2003; 
Serne et al. 2002, 2003, 2010). Much of what researchers know about the intact character of the postbasalt sediments was derived from these recent, more-detailed characterization studies.

\subsection{Quality Ranking of Boreholes}

Because of the wide range in quality of these data associated with the multitude of wells drilled over the past 60 years, each borehole was first examined for the relative quality of the data. Each borehole was assigned a data-quality rank from 1 to 5 , with $\# 1$ having the highest confidence and least uncertainty in the geologic interpretation (Table 2.1). Those boreholes ranked \#5 (least confidence and highest uncertainty) are associated with boreholes with only a driller's log available. In contrast, boreholes ranked \#1 (highest confidence and least uncertainty) may have geologist's logs accompanied by gamma and neutron-moisture logs, as well as grain-size, $\mathrm{CaCO} 3$, and/or other characterization data.

Boreholes with the highest ranking (\#1) include more recently drilled boreholes possessing the most and best quality of data. Ranking is also strongly affected by the drill method, which can alter the original character of the sediments used to distinguish one stratigraphic unit from another. Thus, those boreholes drilled using the open drive-barrel, split-spoon, or direct-push methods generally received a higher ranking than those drilled via the percussion-type, hard-tool method. Data from $36 \%$ of the boreholes are considered good quality, while $38 \%$ are considered of moderate quality, indicating that overall the data are usable for developing the Gable Gap conceptual model (Figure 2.3).

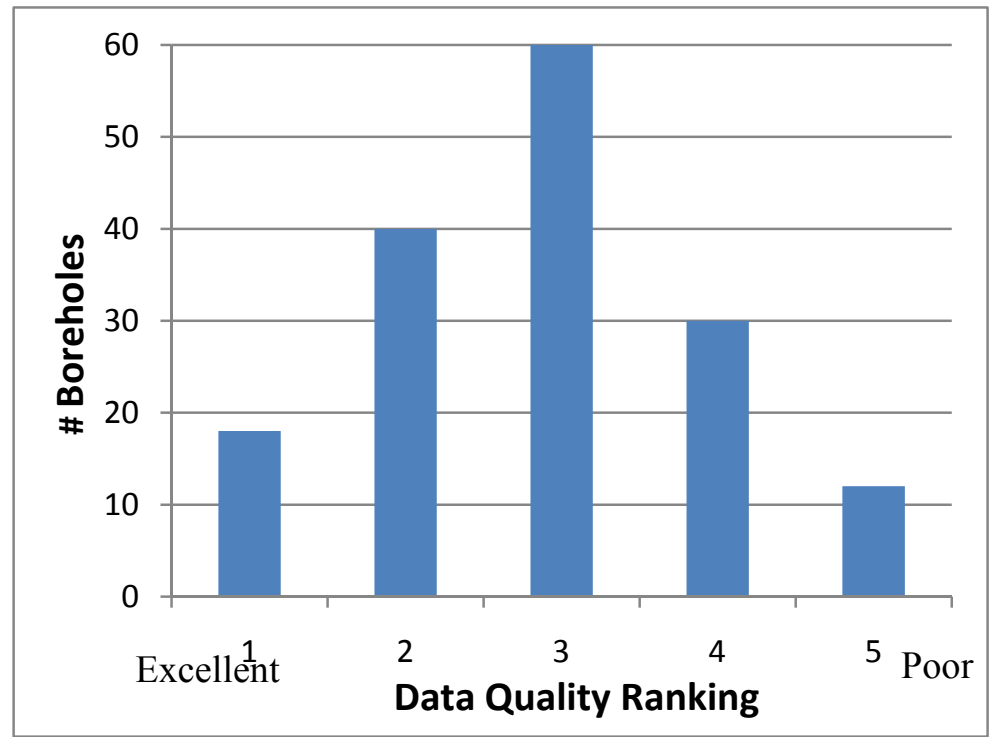

Figure 2.3. Quality ranking comparison of $\sim 150$ boreholes in the Gable Gap study area. $1=$ highest quality and $5=$ lowest quality. About $75 \%$ of the boreholes are considered to be of moderate to good quality. The remaining $25 \%$ are older boreholes with limited amounts of useful data for evaluating the hydrogeology of the study area.

Nearby boreholes frequently show conflicts in interpreted lithology and stratigraphy. In some cases, true differences may exist between the boreholes, but conflicts are often the result of comparing a sparse data set from an older well with a more robust data set from a modern well. The ranking system provides 
a way to resolve conflicts among wells; preference is simply given to the higher-ranking wells.

Interpretations are therefore justifiably biased in favor of the wells with the greatest quantity and highest quality of data.

\subsection{Development of Conceptual Hydrogeologic Model}

Defining contact picks for stratigraphic units (Appendix E) from borehole data is an iterative process. The process of building the model followed a series of investigative steps that were designed to honor the data and give preferential treatment to the higher-ranked boreholes. First, the main stratigraphic units and contacts were identified in boreholes ranked \#1 or \#2. This was done by comparing available data and picking depths to major lithologic contacts (i.e., units with roughly uniform grain size or geologic character). Elevations and thicknesses of the major stratigraphic contacts were then calculated from the depths. The same procedure was next performed on the lower-ranked boreholes.

The next step in building a geohydrologic model of the subsurface was to construct scaled cross sections linking boreholes together. A total of five cross sections (located in Figure 2.4) are presented in Appendix A (Figures A.2 to A.6).

Subsequently, elevations and thicknesses of these major units were spatially plotted onto structurecontour (Appendix B) and isopach (Appendix C) maps. These maps were used to evaluate if the contacts appear realistic and make sense geologically. If the contacts are chosen correctly, the data should plot as relatively smooth surfaces, transitioning from one borehole to another. Isolated, large, steep-gradient "bull eyes" on contour maps indicate the contact may be miscalculated; in these cases, boreholes would be re-evaluated and contacts adjusted as necessary. Structure contour and isopach maps were replotted and further evaluated to ensure the best possible picks were made for each stratigraphic unit. The final spreadsheet of stratigraphic picks used to construct contour maps for the different units is presented in Appendix E. These data are now managed and maintained in the Hanford Geologic Contacts Database at PNNL, with future accessibility through the Hanford Environmental Information System (HEIS).

Another step in developing the hydrogeologic model is to evaluate groundwater-contaminant plumes from nearby waste-management areas. Contaminants are a type of tracer, which conveniently provide a means to evaluate the rate and direction of groundwater flow. Figure 2.5 shows the distribution of two contaminant plumes (uranium and ${ }^{99} \mathrm{Tc}$ ) in the vicinity of Gable Gap. The plumes appear to emanate from waste facilities associated with the B-BX-BY Tank Farms (Serne et al. 2010), and move in a northwesterly direction via at least one paleochannel across a buried divide in the basalt bedrock.

\subsection{Integration of Geophysics Data}

Where available, surface-geophysical surveys (i.e., seismic-reflection profiles) were also used for interpolating the top of basalt between boreholes (Figure 2.5). These data were especially useful for estimating the top of basalt in hydrogeologic cross sections (Figure 2.3; Appendix A). One long and several shorter seismic-reflection lines collected in the late 1970s as part of the Basalt Waste Isolation Project (BWIP) (Holmes and Mitchell 1981; Ault 1981) were evaluated and reprocessed. These have been augmented with data from eight new shorter lines of seismic-reflection lines, totaling $11 \mathrm{~km}$ in length, via the Landstreamer device (Repasky et al. 2009). The uppermost reflector observed along seismic-reflection profiles is often interpreted as the top of basalt, which has significantly higher density 
than the overlying suprabasalt sediments. However, reflection surfaces and other anomalies on seismic profiles can be generated in many other ways, including erosional surfaces, lateral lithologic (i.e., facies) changes, unconformities, faults and folds, poor quality data, seismic-signal attenuation, and inconsistencies in data processing (Holmes and Mitchell 1981). Therefore, the uppermost seismicreflector may not always represent the top of basalt, and the seismic data need to be carefully evaluated with other reflection sources in mind. Lithologic data collected in boreholes should always be honored foremost, and where present, used to effectively constrain and calibrate the seismic data.

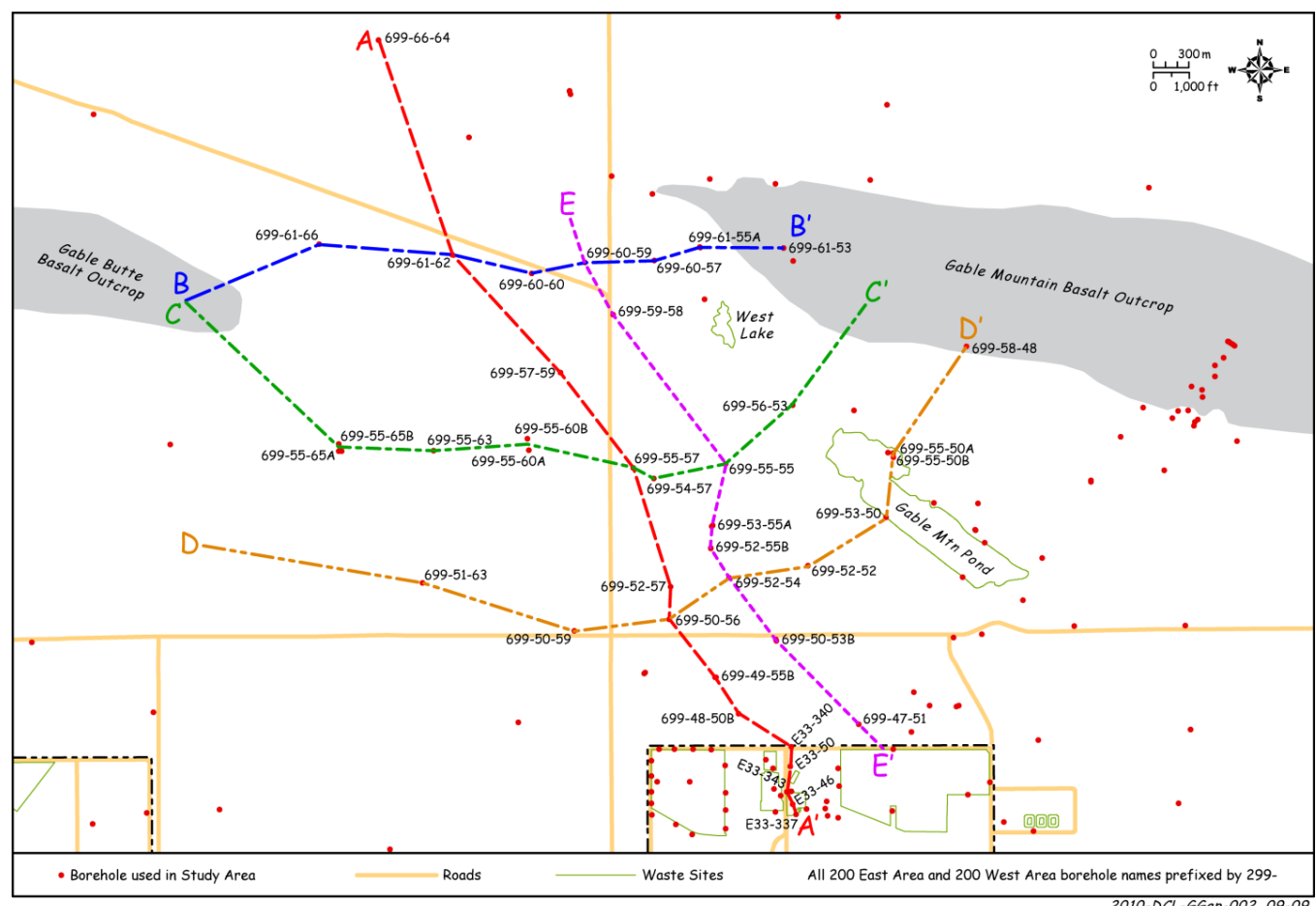

Figure 2.4. Locations of five hydrogeologic cross sections within the study area. See Appendix A for cross sections. 


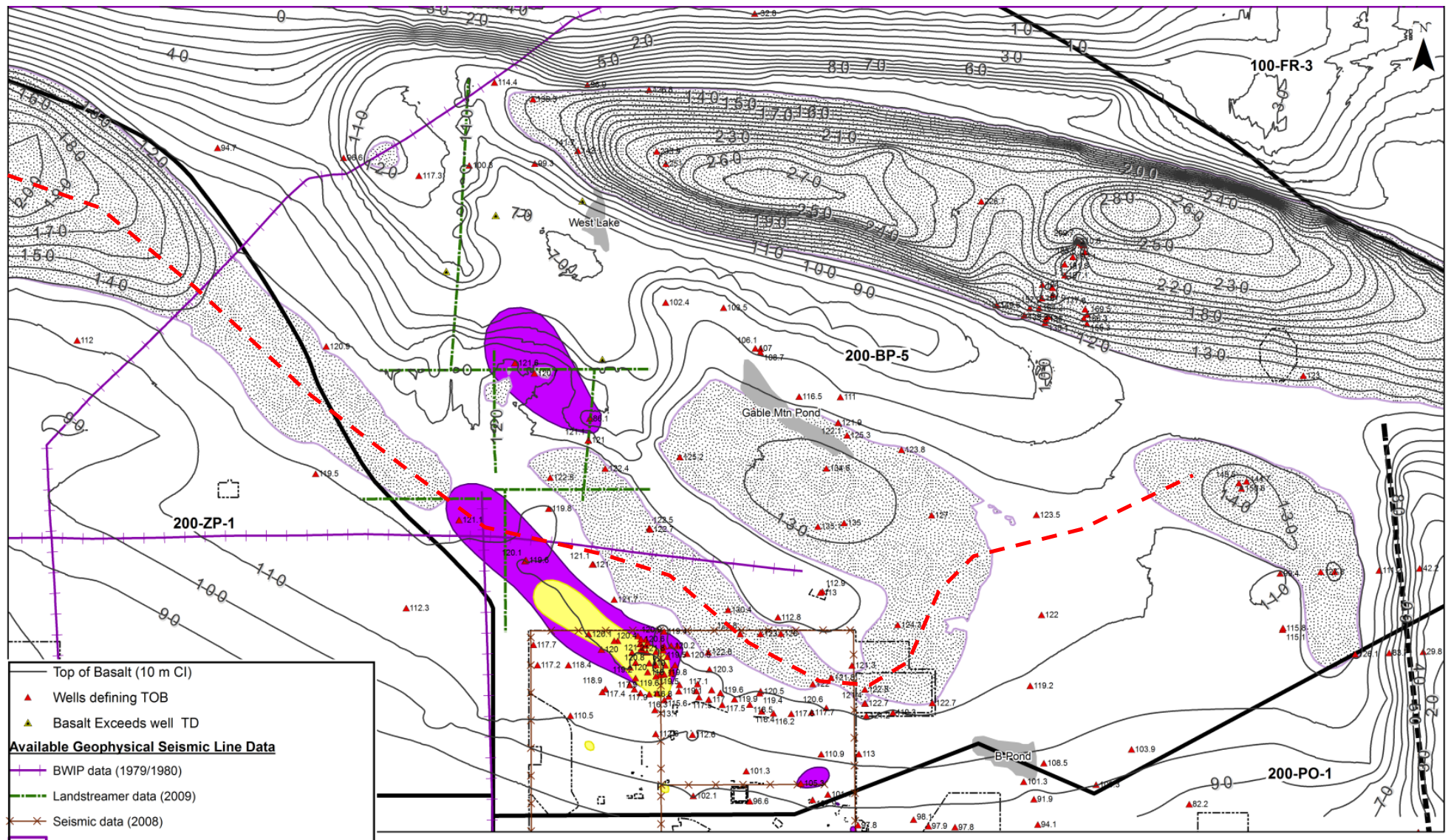

Top of Basalt Structure Map, BP-5 Operable Unit

Basalt Subcrop above 2009 WT within model Doma

Uranium 2009 (30 ug/L)

Technetium-99 2009 (900 pCil)

May Junction Faul

Figure 2.5. Latest top of basalt interpretation based on borehole and seismic-reflection-survey data in the Gable Gap area. Also shown are groundwater-contaminant plumes for uranium and ${ }^{99} \mathrm{Tc}$ in the vicinity of Gable Gap. Purple lines are seismic lines collected in 19791980 as part of the BWIP Project (Ault 1981); green lines show locations of Landstreamer seismic-reflection surveys (Repasky et al. 2009). Note: top of basalt contours are in meters. Dashed red line connects high points of basalt divide. 


\subsection{Regional Geologic Setting}

The Hanford Site and Pasco Basin lie within the Columbia Plateau of southeastern Washington State. This broad plain, situated between the Cascade Mountains to the west and the Rocky Mountains to the east, is underlain by a thick sequence of volcanic Columbia River basalt, which forms the basement rock for the region.

The generalized stratigraphy beneath the Hanford Site consists of, in ascending order, the Columbia River Basalt Group (CRBG) and intercalated sediments of the Ellensburg Formation, the Ringold Formation, the Cold Creek unit (formerly named the Plio-Pleistocene unit), and the Hanford formation (Figure 3.1). The Cold Creek unit and Hanford formation are both informal designations. Thin veneers of Holocene alluvium, colluvium, and/or eolian sediments discontinuously overlie these principle geologic units. The regional suprabasalt stratigraphy is described in more detail elsewhere (DOE 1988; Lindsey 1995, 1996; DOE/RL 2002).

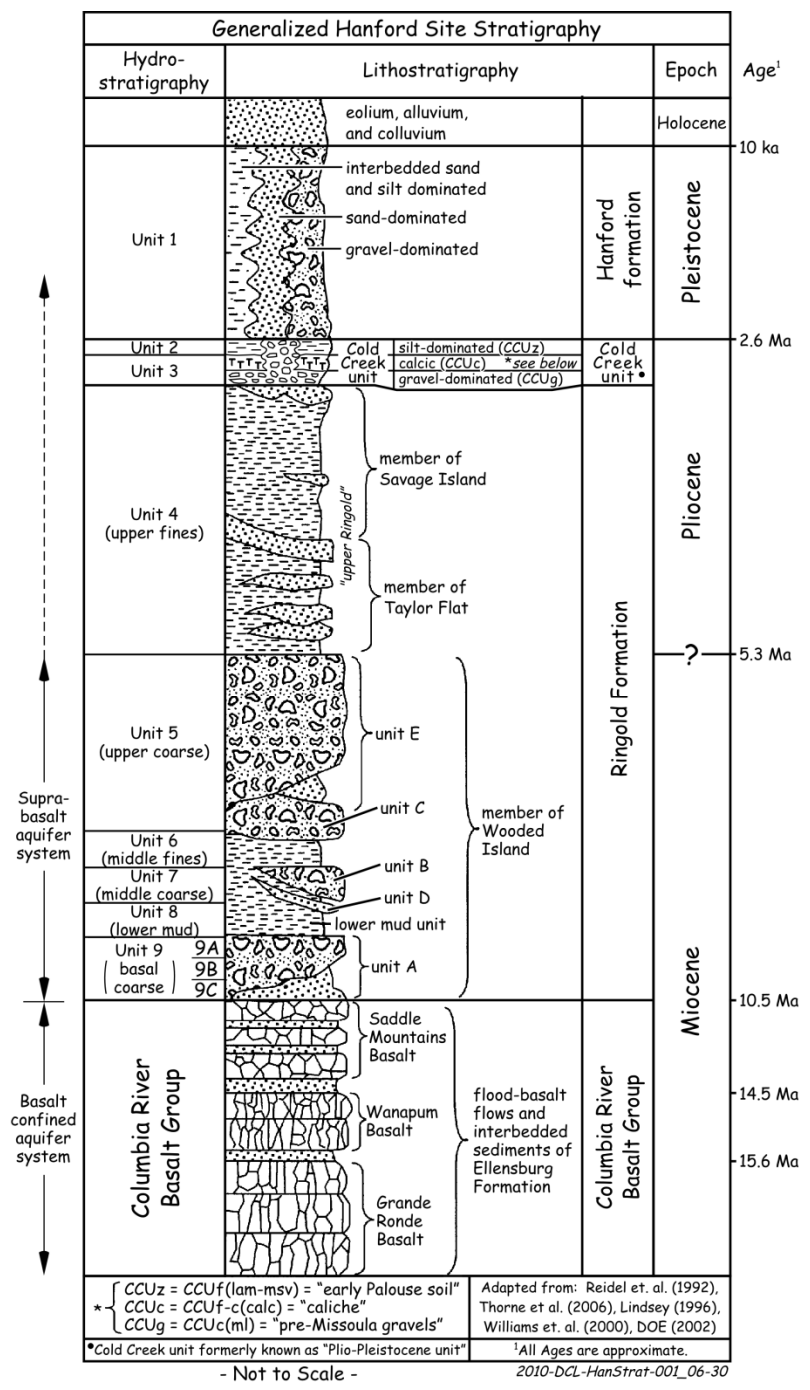

Figure 3.1. Regional stratigraphy for the Pasco Basin and Hanford Site. Modified after DOE/RL (2010). 


\subsection{Columbia River Basalt Group and Ellensburg Formation}

The CRBG in eastern Washington is divided into three formations: 1) Grand Ronde Basalt, 2) Wanapum Basalt, and 3) Saddle Mountains Basalt (Figure 3.2). About 300 separate flows have been identified; the basalt reaches its maximum thickness, $\sim 15,000 \mathrm{ft}(4570 \mathrm{~m})$, in the southern Pasco Basin. The last basalt flows to reach the Pasco Basin occurred between 8.5 to 10.5 million years ago (DOE 1988). The extrusion of volcanic basalt flows occurred very rapidly at first and then slowed down over time. More time between basalt eruptions allowed for more accumulation of sediments between the younger basalt flows (i.e., Saddle Mountains Basalt). The sedimentary interbeds of the Ellensburg Formation, along with the porous basalt flow tops and bottoms, form confined aquifers that may extend across the Pasco Basin (DOE 1988).

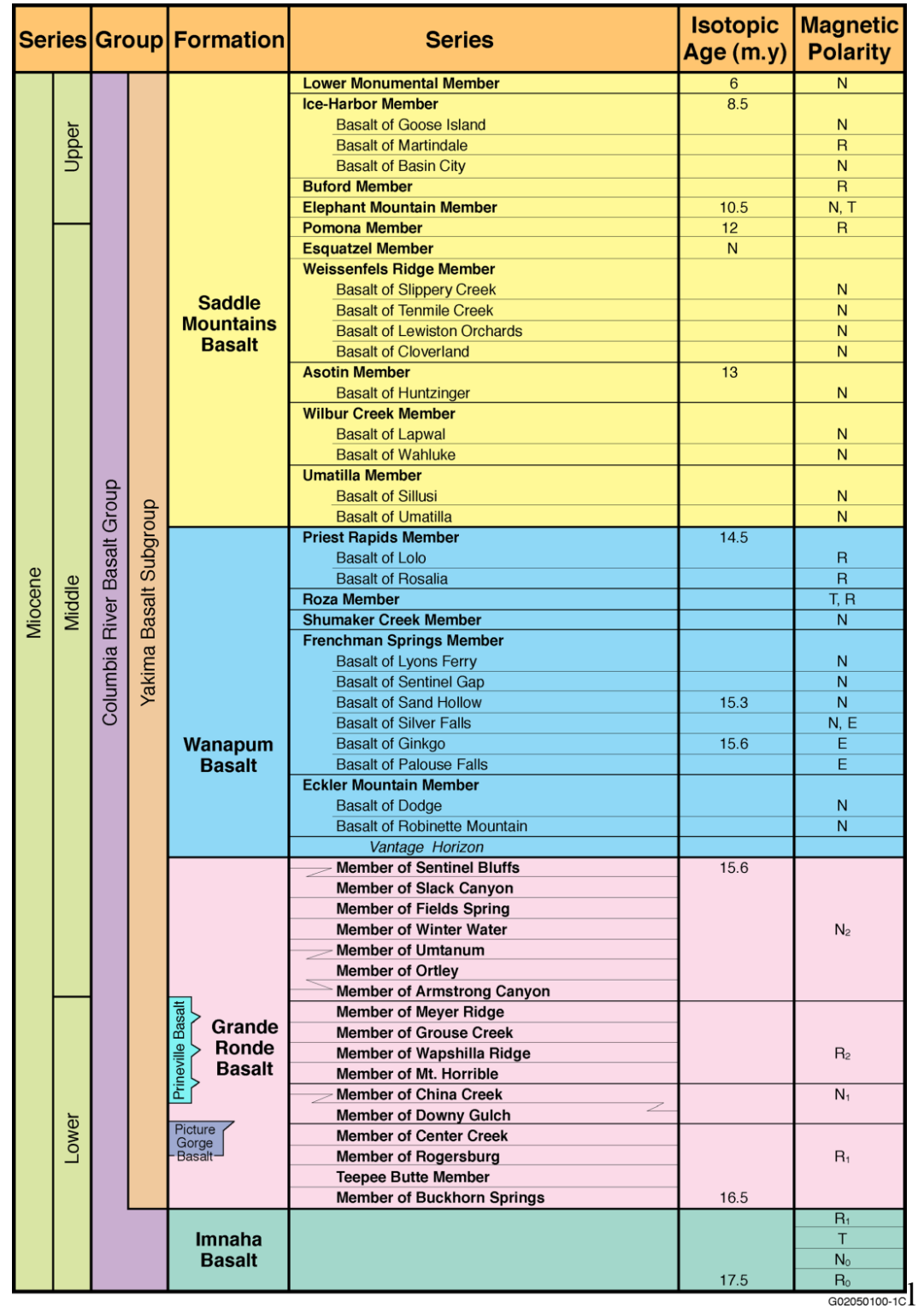

Figure 3.2. Stratigraphic nomenclature for the Columbia River Basalt Group. All basalt formations but the Imnaha Basalt are present in eastern Washington State. Source: Martin et al. (2005). 
The basalt flows and interbeds have been folded and faulted, creating broad structural and topographic lows, separated by tighter asymmetric anticlinal ridges. Tectonic folding and faulting, which began with extrusion of the CRBG, continues to the present day (Reidel 1984; DOE 1988). Sediments of late Miocene, Pliocene, and Pleistocene age have accumulated up to $1700 \mathrm{ft}(520 \mathrm{~m})$ thick in the Pasco Basin, one of the larger structural basins. The Pasco Basin is partially bisected by the first-order Umtanum Ridge-Gable Mountain anticline creating two subordinate synclinal basins (Cold Creek and Wahluke synclines).

\subsection{Suprabasalt Sediments}

\subsubsection{Ringold Formation}

The Ringold Formation records fluvial-lacustrine deposition associated with the ancestral Columbia River drainage system, following the last eruption of basalt at the Hanford Site (Tallman et al. 1981; DOE 1988; Lindsey 1995, 1996). Deformation of the Yakima folds, which began in the middle Miocene Epoch coincident with emplacement of the Columbia River basalt flows, continued into Ringold time so the centers of down-warped basins received more sediment than the margins. The Ringold Formation is up to $600 \mathrm{ft}(185 \mathrm{~m})$ thick in the center of the basin and pinches out against the basin-bounding basalt ridges.

The Ringold Formation consists of semi-indurated clay, silt, fine- to coarse-grained sand, and variably cemented, multilithic, granule to cobble gravel. Ringold Formation sediments have been classified into five sediment facies associations:

1. fluvial gravel

2. fluvial sand

3. overbank deposits

4. lacustrine deposits

5. alluvial fan deposits.

See Lindsey $(1995,1996)$ for more detailed descriptions of these facies.

\subsubsection{Cold Creek Unit}

After a period of post-Ringold incision, the eroded surface of the Ringold Formation was locally weathered and/or covered with accretionary deposits of the Cold Creek unit. These deposits consist of fluvial, eolian and/or colluvial sediment, often pedogenically altered (DOE/RL 2002). The Cold Creek unit includes those deposits formerly referred to as the "Plio-Pleistocene unit" and "Pre-Missoula Gravels," as well as the "early Palouse soil" and "caliche layer" within the 200 West Area. These deposits were renamed because of the uncertainty in their exact age, and to better reflect their geographic extent, which is generally confined to the boundaries of the Cold Creek syncline within the west-central Pasco Basin (DOE/RL 2002). 
Five different facies of the Cold Creek unit have been differentiated based on grain size, sedimentary structure, sorting, roundness, fabric, and mineralogic composition (DOE/RL 2002). These facies include the following:

1. fluvial-overbank and/or eolian (early Palouse soil)

2. calcic paleosol (caliche)

3. mainstream alluvium (Pre-Missoula Gravels)

4. colluvium

5. sidestream alluvium.

\subsubsection{Hanford Formation}

The Hanford formation is an informal name used within the Pasco Basin to describe Pleistocene-age cataclysmic flood deposits (Tallman et al. 1979, 1981; DOE 1988; DOE/RL 2002). Ice-Age floods originated from outbursts of glacial Lake Missoula, as well as other ice-dammed lakes (Baker and Bunker 1985), pluvial lake Bonneville (O’Connor 1993), or possible subglacial floods (Shaw et al. 1999) associated with the Cordilleran Ice Sheet. At least one flood also occurred from the draining of glacial Lake Columbia at the very end of the Ice Age (Bjornstad 2006). The Hanford formation may include some minor fluvial, colluvial, and/or eolian deposits interbedded with flood deposits.

As mentioned above, the Hanford formation consists predominantly of unconsolidated sediments that cover a wide range in grain size, from boulder-size gravel to sand, silty sand, and silt. The sorting ranges from poorly sorted (for gravel facies) to well sorted (for fine sand to silt facies). Traditionally, the Hanford formation has been subdivided into three lithofacies (gravel dominated, sand dominated, and interbedded sand and silt-dominated), which grade into one another both vertically and laterally (DOE/RL 2002).

The interbedded sand- and silt-dominated facies (DOE/RL 2002) occurs in backflooded, slackwater areas marginal to the Ice Age floods. As such, this facies is not present in the vicinity of Gable Gap due to extremely high-energy, turbulent flood flow through the Gap. Sand-dominated facies of the Hanford formation consist of relatively thick $(\geq 1 \mathrm{~m})$, predominantly horizontally laminated, loose, basalt-rich, fine- to coarse-grained sand, sometimes grading upward into a thinner sequence of ripple-laminated fine sand to silt. Typically, sand-dominated facies contain approximately equal amounts of mafic (i.e., basalt) and quartz-feldspar grains (Tallman et al. 1979); this composition gives the Hanford formation its characteristic "salt and pepper" appearance. Gravel-dominated facies consist of loose, massive to horizontal and large-scale, planar-tabular cross-bedded, poorly sorted mixtures of gravel, sand, and silt. Gravel clasts in flood gravels generally consist of 50\% to $75 \%$ subangular to subrounded basalt (DOE/RL 2002). Rounded rip-up clasts of caliche and/or semi-indurated silt and clay are common in the graveldominated facies.

Below an elevation of approximately 1,000 ft (300 m) within the central Pasco Basin, the Hanford formation unconformably overlies the Cold Creek unit, and where the unit is not present, lies directly on the Ringold Formation or Columbia River basalt. Within the central Pasco Basin buildup of flood deposits occurred along Priest Rapids, Cold Creek and Gable Mountain flood bars, which developed as the floods initially expanded into the Pasco Basin (Figure 3.3). The bulk of the vadose zone at the Hanford Site lies within Ice Age flood sediments of the Hanford formation. 
Ice-Age floods created the Cold Creek Bar, a giant, streamlined deposit of mostly gravel and sand that extends for 12 miles downstream of Umtanum Ridge (Figure 3.3). Gravel-dominated deposits, laid down under the strongest flood currents, are generally restricted to the north side of the bar. At the southern end of the bar, where flood currents were less vigorous, sand-dominated sediments were laid down. The Hanford formation reaches its maximum thickness ( $300 \mathrm{ft}[100 \mathrm{~m}])$ in the sand-dominated facies beneath the Cold Creek Bar just south of the study area.

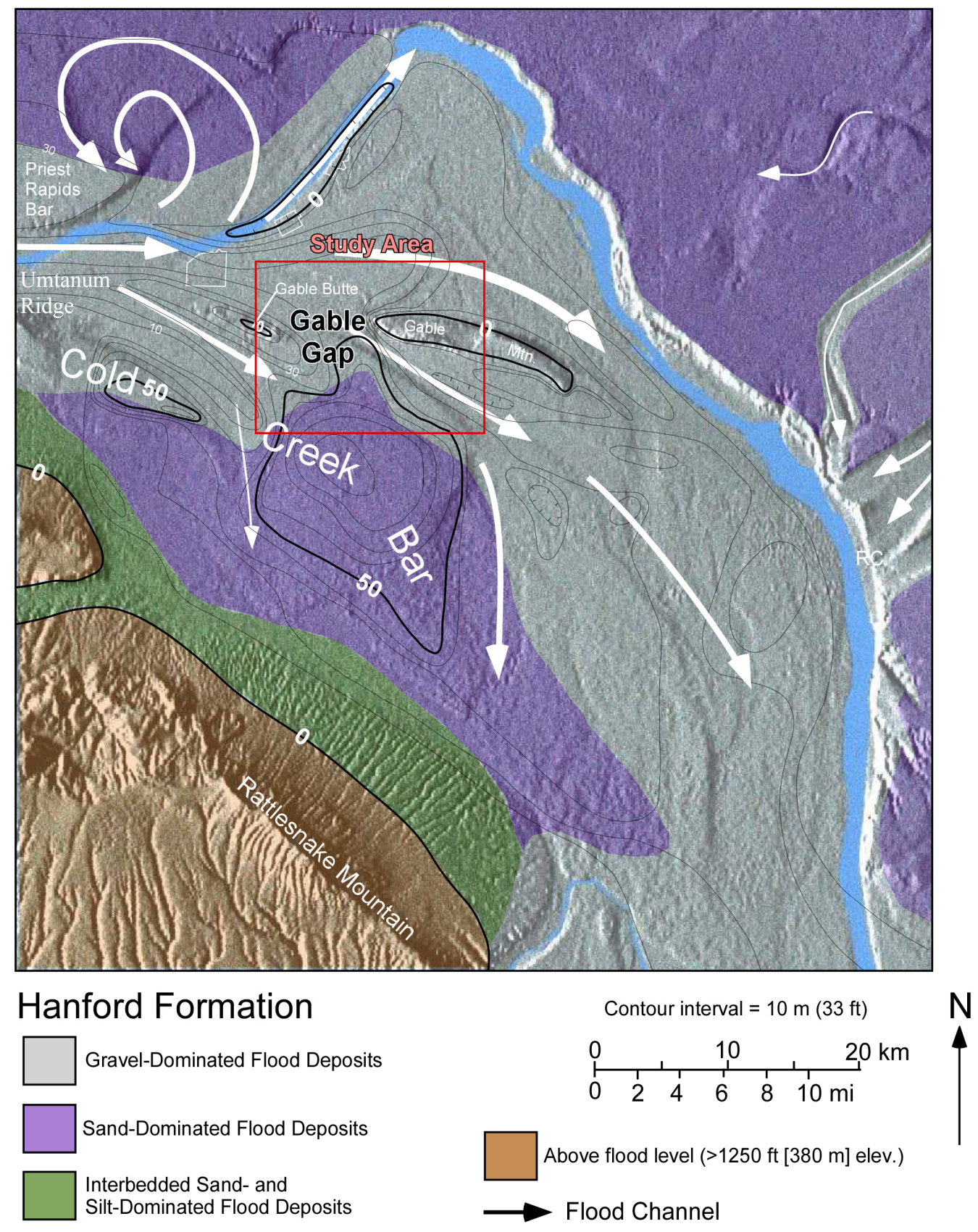

Figure 3.3. Thickness and distribution of cataclysmic flood deposits (i.e., Hanford formation) within the central Pasco Basin. Modified after DOE/RL (2002). 


\subsection{Stratigraphy and Lithology of Gable Gap}

The following discussion on the hydrogeology of Gable Gap presents background information on the stratigraphy, lithology, structure, paleogeomorphology, and hydrology, which forms the basis for the three-dimensional hydrogeologic model developed herein.

A total of nine stratigraphic units are recognized in the Gable Gap area (Figure 4.1).

- Recent eolian or backfill material

- Hanford formation - upper gravel-dominated sequence (H1 unit)

- Hanford formation - sand-dominated sequence (H2 unit)

- Hanford formation - lower gravel-dominated sequence (H3 unit)

- Cold Creek unit - silt-dominated subunit

- Cold Creek unit - gravel-dominated subunit

- Ringold Formation (undifferentiated)

- Columbia River Basalt Group (CRBG)

- Sedimentary interbeds between Columbia River basalt flows (Ellensburg Formation).

Stratigraphic relationships and images for these units are illustrated in Figures 4.1 and 4.2, and tabulated in Table 4.1. Hydrogeologic cross sections (e.g., Figure 4.2) displaying more of the stratigraphic and structural relationships among lithologic units are presented in Appendix A. Structurecontour and isopach maps for most of the units are also presented in Appendices B and C, respectively. As illustrated in these appendices, all but the Hanford formation $\mathrm{H} 1$ unit are discontinuous across the Gable Gap study area. More detailed discussions of each unit, beginning with the oldest unit, are presented in the following sections. 

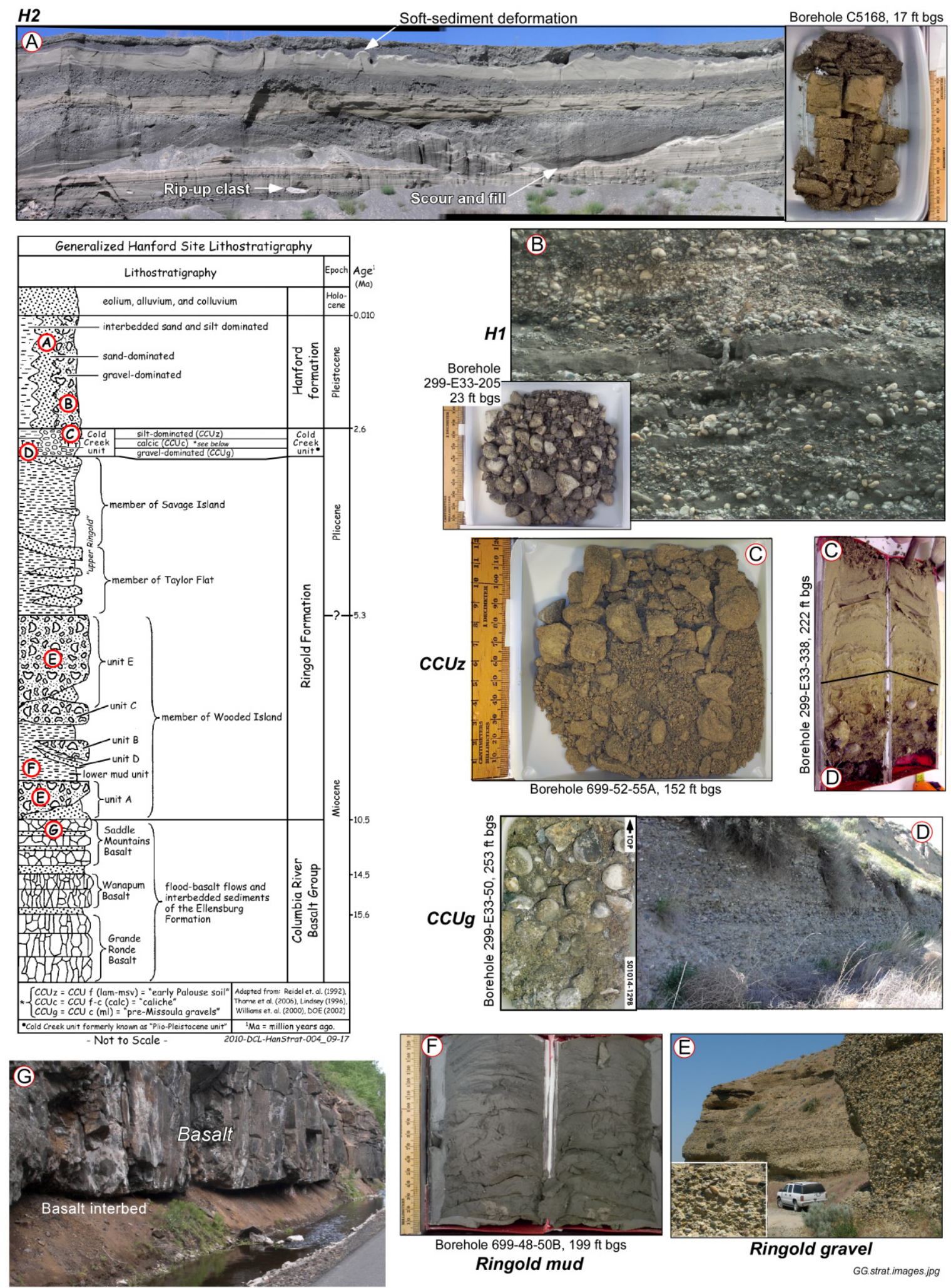

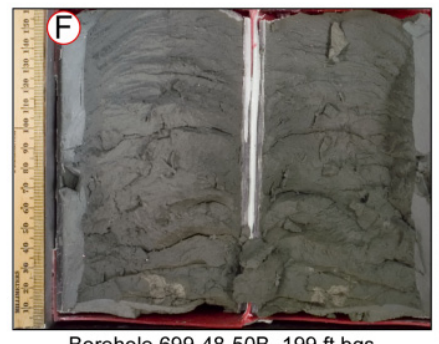

Borehole 699-48-50B, $199 \mathrm{ft}$ bgs Ringold mud

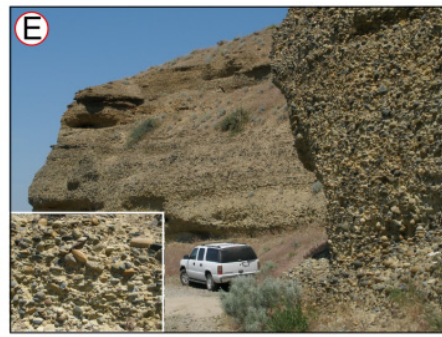

Ringold gravel

GG.strat.images.jpg

Figure 4.1. Hanford Site stratigraphy. Photos show examples of strata, both in drill core and outcrop, which are representative of the Gable Gap study area. Borehole number and depth of sample below ground surface (bgs) are shown where appropriate. 


\subsection{Columbia River Basalt Group and Interbedded Sediments of the Ellensburg Formation}

The surface of the volcanic CRBG forms the bedrock base beneath sedimentary deposits over the Hanford Site. Volcaniclastic sedimentary interbeds of the Ellensburg Formation accumulated between basalt flow eruptions. Sediments of the Ellensburg Formation commonly thin or disappear in adjacent anticlines that lay above the ancient valley floors.

The Elephant Mountain Member of the CRBG's Saddle Mountains Basalt (Figure 4.2) is the youngest basalt flow within the Gable Gap study area and where present forms the basement rock (Figure 4.3). The Elephant Mountain Member has been dated by the K-Ar method to be about $10.5 \mathrm{Ma}$ (McKee et al. 1977) and consists of two flows beneath the 200 East Area. However, within the northern portion of Gable Gap, the uppermost basalt flows that include the Elephant Mountain Member, were locally folded, faulted, and subsequently eroded by the ancestral Columbia River and Pleistocene Ice Age floods (Figures 4.3 and C.10). A large erosional window exists across a sizable portion of the gap where the Elephant Mountain Member was completely eroded, exposing older basalt flows and the Ellensburg Formation to the unconfined aquifer. Locally, this erosional window extends all the way down to the Umatilla Member of the CRBG. This deep cavity allows hydraulic communication between confined and unconfined aquifers in this area (Strait and Moore 1982; Graham et al. 1984; Jensen 1987). Both north and south of the anticlinal axis at Gable Gap, however, the basalt of the Elephant Mountain Member forms a continuous unit that dips uniformly into synclinal basins on either side.

The Ellensburg Formation consists mostly of fine-grained tuffaceous beds of clay and silt, interstratified with sandy layers (see Figures A.1, A.3, and A.5). No gravel facies are reported for the Ellensburg Formation within the study area, except locally within the uppermost interbed (Rattlesnake Ridge) along the basal contact with the Pomona Member (Jensen 1987). The Rattlesnake Ridge interbed is up to $60 \mathrm{ft}(18 \mathrm{~m})$ thick in the study area (see Figure C.10); however, it was totally removed by erosion associated with the ancestral Columbia River and/or Ice Age floods within Gable Gap where it crosses the axis of the Umtanum Ridge-Gable Mountain anticline. 


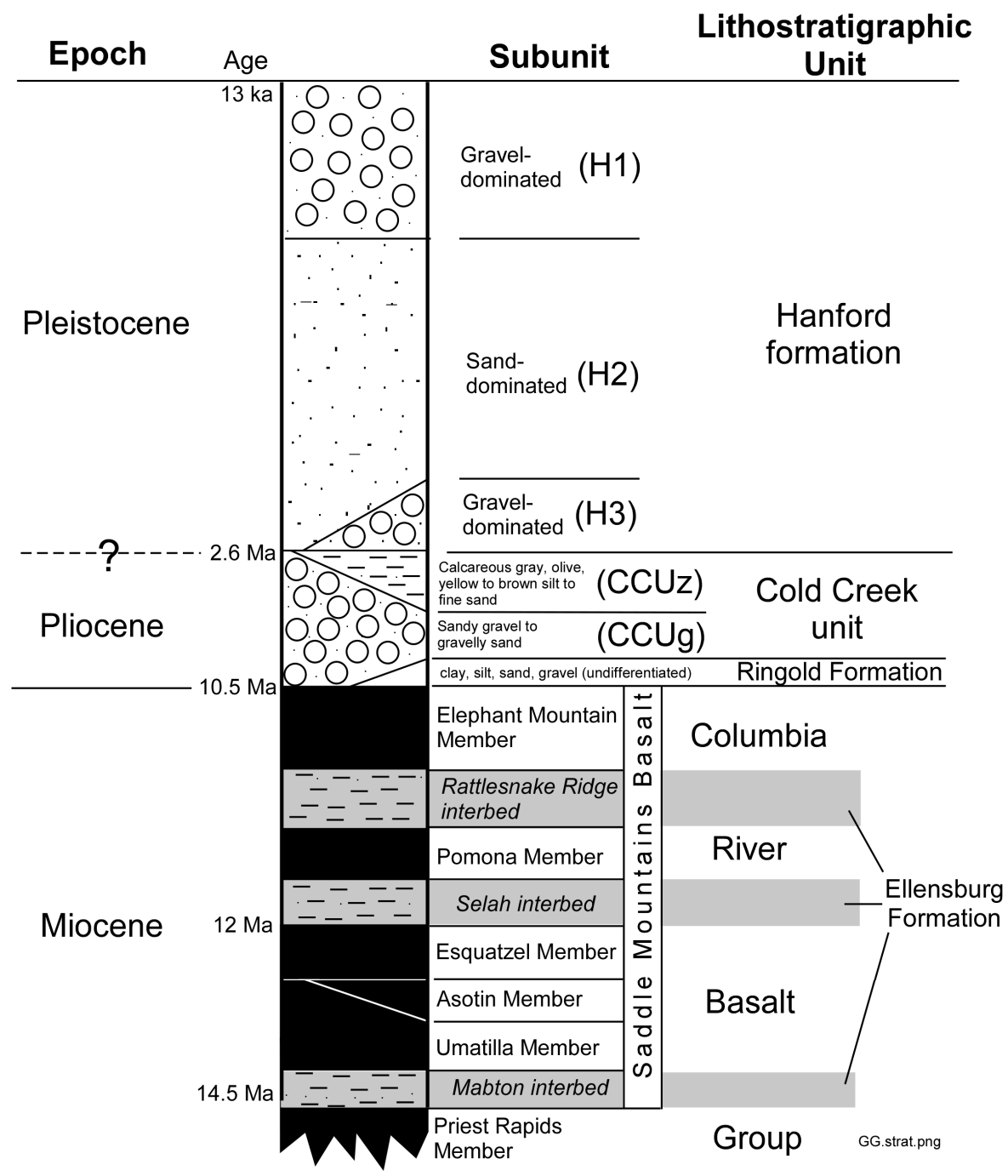

Figure 4.2. Stratigraphy in the vicinity of Gable Gap 


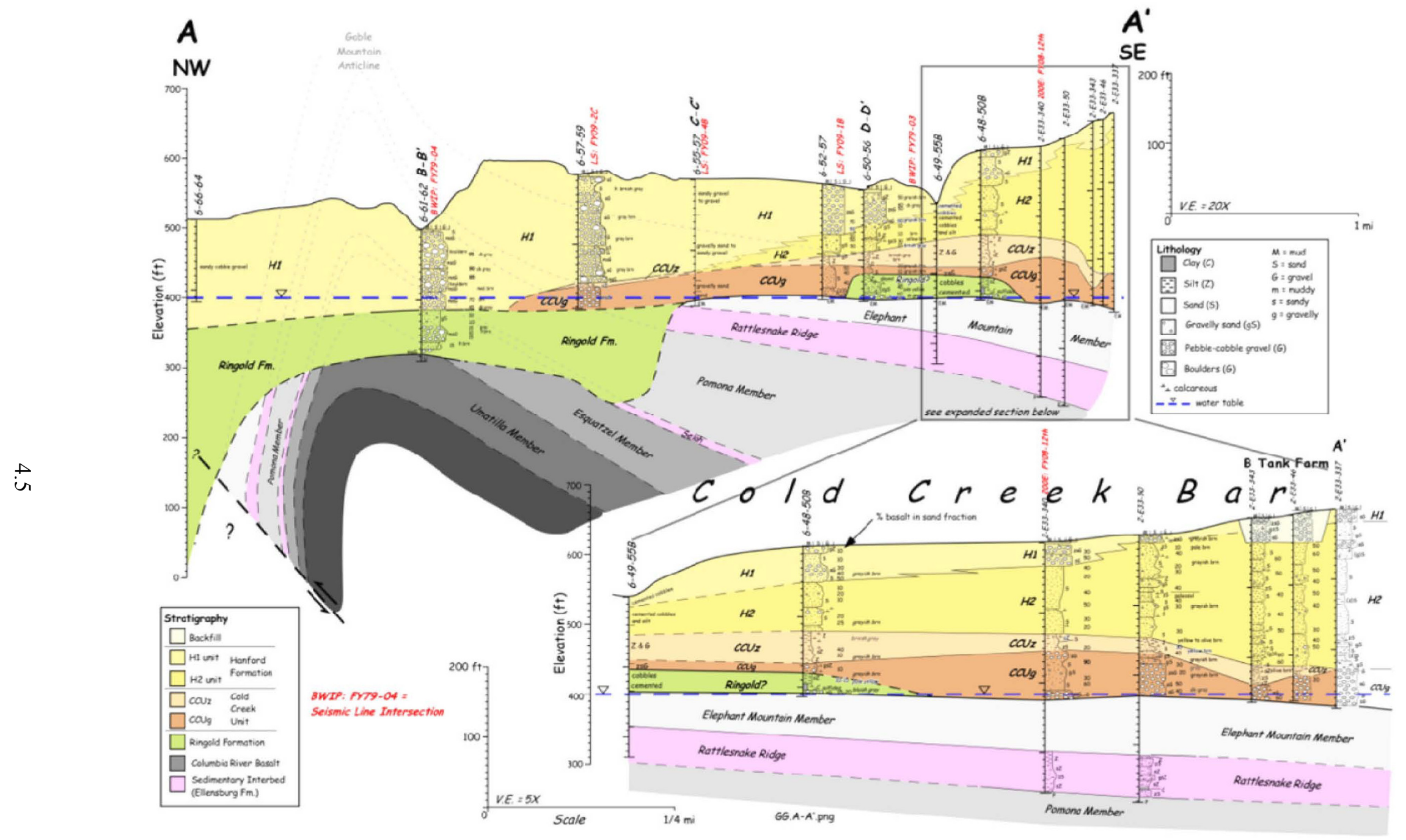

Figure 4.3. Example hydrogeologic cross section (A-A') for Gable Gap. See Figure 2.4 for location and Appendix A for other cross sections. 


\subsection{Suprabasalt Sediments}

Suprabasalt sediments are those deposits that lie above and are younger than the basalt flows of the CRBG and interbedded sediments of the Ellensburg Formation. The suprabasalt sediments in Gable Gap include the Ringold Formation, the Cold Creek unit, and the Hanford formation. The characteristics of these stratigraphic units are summarized in Table 4.1. A thin veneer of Holocene sediments (eolian sand, slopewash, or manmade backfill) also locally covers the surface.

\subsubsection{Ringold Formation}

Only a few thin, erosional remnants of the fluvial-lacustrine Ringold Formation are preserved within Gable Gap; these lie mostly within Ringold-age paleochannels and beneath protective caps of the cohesive Cold Creek unit silt (CCUz) (see Figures A.2 to A.5). At one time, the Ringold Formation was much thicker and more widely distributed across the Gable Gap area when it filled the Pasco Basin to $\sim 900 \mathrm{ft}$ (274 m) elevation (Lindsey 1995) during the late Miocene to Pliocene time (10.5-3.4 Ma). However, either during, or since, Ringold time uplift of the Umtanum Ridge-Gable Mountain anticline caused subsequently incision and removal of the Ringold Formation. Additional downcutting occurred via the post-Ringold Columbia River, followed by scouring from multiple, cataclysmic Ice Age floods.

Figure C.8 shows the wells within Gable Gap that encountered the Ringold Formation. These wells are mostly restricted to lower-elevation paleochannels or margins of paleochannels within Gable Gap. In general, the Ringold sediments in Gable Gap wells represent a variety of different lithofacies (see Figures 4.3 and 4.4) from fine-grained silt and clay to sand and gravel. Because only a thin sequence and

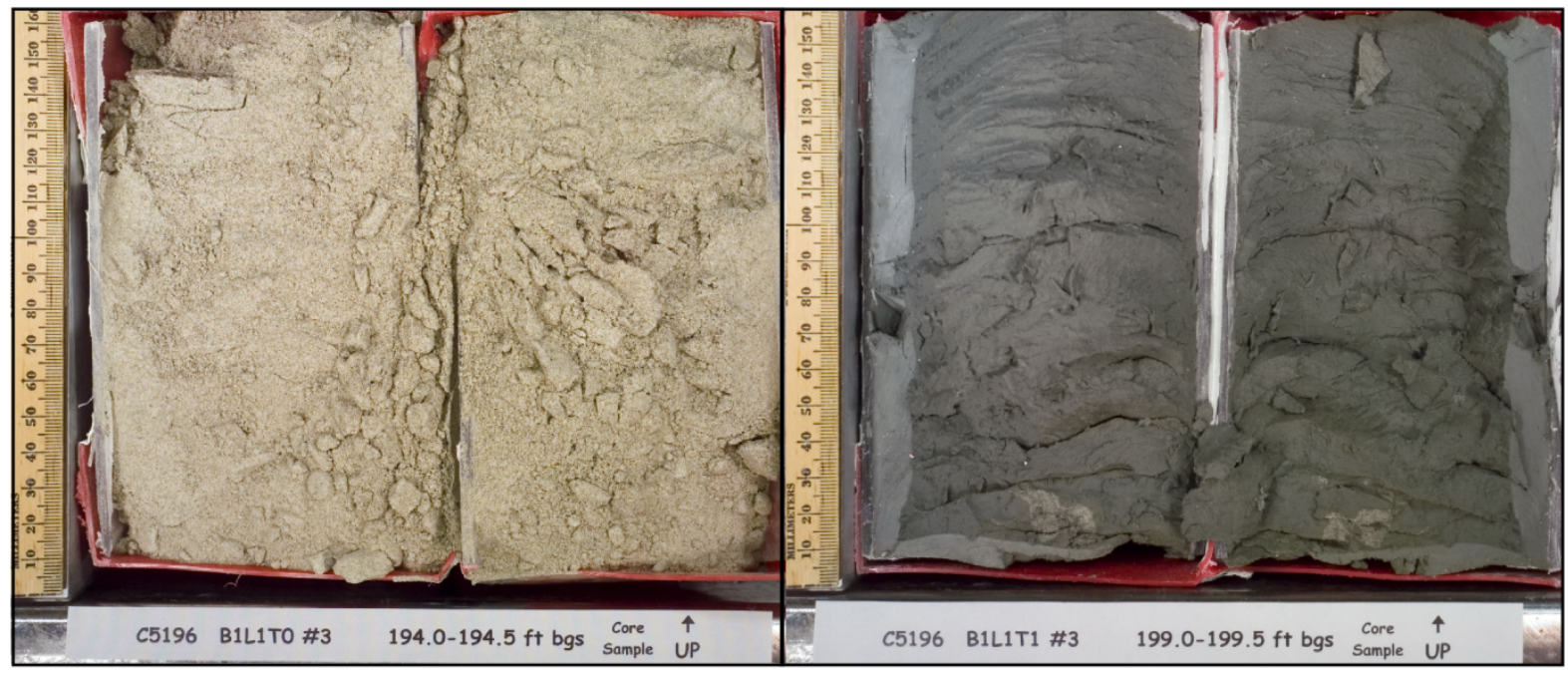

gg.ringold.png

Figure 4.4. Erosional remnants of the Ringold Formation in Gable Gap well 699-48-50B (C5196). See borehole location map in Figure 2.1. Left: Weakly laminated, pale yellow, micaceous, wellsorted, fine- to medium-grained sand. Note the felsic composition with only a few percent dark mafic grains, $194 \mathrm{ft}(59 \mathrm{~m})$ depth. Right: Well-laminated, slightly plastic, clayey silt from 199-ft (61-m) depth. The gleyed (olive gray) color and sulfide smell of these sediments are indicative of ongoing chemical reduction within this facies. Both of these Ringold sediments are interpreted as fine-grained, fluvial-overbank deposits of the ancestral Columbia River. See also summary log for this well in Figure 2.2. 
multiple lithofacies of the Ringold Formation are represented in Gable Gap, it is presently not possible to positively identify to which specific Ringold units (i.e., Lindsey 1995; Williams et al. 2000) these sediments belong. For this report, we are designating gravelly Ringold facies as belonging to Ringold Formation unit A, and overlying fine-grained strata to the Ringold lower mud unit. These units may or may not correlate with similarly named units outside the Gable Gap study area.

Distinguishing characteristics of the gravel-dominated Ringold facies (described in Table 4.1) are generally moderately sorted and bimodal consisting of rounded, clast-supported, pebble-cobble conglomerate in a sand to silt matrix. The sand fraction is predominantly light-colored and felsic (quartz, feldspar, and mica) with only a few percent mafic grains. Individual sediment grains and clasts in coarser Ringold facies are frequently coated with a red, yellow, orange, and/or brown cement that weakly to moderately binds particles together. Gravel clasts are normally described as multilithic and often display clay coatings. Gravels are composed of a mixture of mostly quartzite, granitic, gneissic, and basalt clasts. Basalt clasts in particular often show significant weathering rinds while granitic/gneissic clasts can be strongly weathered and friable-all signs of significant in-situ weathering caused by millions of years of contact with groundwater. Ringold gravel clasts are typically highly rounded and polished, characteristic of a fluvial setting (i.e., ancestral Columbia River). Another characteristic of the gravel-dominated Ringold Formation is its ability to maintain an open-hole during drilling due to its older age, which produces sediments that are more compacted, cemented, and/or consolidated.

Finer-grained Ringold strata are also present in Gable Gap; these are composed of interstratified beds of massive to laminated clay, silt, and sand (Figure 4.4).

\subsubsection{Cold Creek Unit}

A geologic unit of late Pliocene to possibly early Pleistocene age is also present in the vicinity of Gable Gap. The unit consists of a thick (up to $55 \mathrm{ft}$ [17 m] in well 699-49-55A) layer of fine-grained, well-sorted, calcareous silt and/or fine sand that generally lies several tens of feet above the top of basalt. Two different facies of the Cold Creek unit (DOE/RL 2002) appear to be present in Gable Gap: 1) a gravel-dominated subunit (CCUg), overlain by 2) a fine-grained, silt-dominated subunit (CCUz).

Gravel-Dominated Subunit (CCUg). The lower portion of the Cold Creek unit in Gable Gap typically consists of multilithic sand and gravel, similar to the Ringold Formation, except for a higher concentration of basalt clasts (Figure 4.5). However, unlike the Ringold Formation, the Cold Creek unit gravels (CCUg) subunit generally lacks significant weathering and/or consolidation, due to its generally younger age ( $\sim 2$ to 3 million years, compared to up to 10 million years for the Ringold Formation) (see Figure 4.1). The CCUg contains a moderate amount (generally 20-50 vol\%) of basalt in the sand fraction. This is an intermediate composition between that of the Ringold Formation (generally $0-10 \%$ ) and the Hanford formation (40-90\%), although there can be some overlap in the mafic content for the different stratigraphic units. The loose, unconsolidated, and generally unweathered nature of CCUg suggests this subunit is post-Ringold Formation in age. These facies likely represent fluvial deposits from the main channel of the ancestral Columbia River, which incised into and reworked the older, more felsic Ringold Formation, which was mixed with alluvium from other, more-local, basalt-dominated sidestreams. The CCUg typically displays various shades of gray, including brown and olive. 
Table 4.1. Characteristics used to distinguish between suprabasalt stratigraphic units within Gable Gap

\begin{tabular}{|c|c|c|c|c|c|c|c|c|c|c|c|c|c|c|c|}
\hline $\begin{array}{c}\text { Stratigraphic } \\
\text { Unit }\end{array}$ & Lithofacies & Age & $\begin{array}{l}\text { Principal } \\
\text { Lithology }\end{array}$ & $\begin{array}{c}\text { Subordinate } \\
\text { Lithology }\end{array}$ & $\begin{array}{l}\text { Depositional } \\
\text { Process }\end{array}$ & $\begin{array}{c}\text { Depositional } \\
\text { Environment/ } \\
\text { Spatial } \\
\text { Distribution }\end{array}$ & Matrix Color & $\begin{array}{c}\% \text { Basalt } \\
\text { (Mafic) in } \\
\text { Sand } \\
\text { Fraction }\end{array}$ & $\begin{array}{c}\text { General } \\
\text { Gravel } \\
\text { Roundness }\end{array}$ & Sorting & Structure & $\begin{array}{c}\text { Calcium } \\
\text { Carbon- } \\
\text { ate } \\
(\mathrm{wt} \%) \\
\end{array}$ & Induration & $\begin{array}{c}\text { Natural- } \\
\text { Gamma } \\
\text { Response }\end{array}$ & Other Characteristics \\
\hline \multirow[t]{2}{*}{$\begin{array}{l}\text { Hanford } \\
\text { formation }\end{array}$} & $\begin{array}{l}\text { Sand- } \\
\text { dominated } \\
\text { (H2 unit) }\end{array}$ & Pleistocene & $\begin{array}{l}\text { Fine- to } \\
\text { coarse- } \\
\text { grained sand } \\
\text { (S) }\end{array}$ & $\begin{array}{l}\text { Lenses of pebbly } \\
\text { sand (gS), silty } \\
\text { fine sand (mS), } \\
\text { fine sandy silt } \\
\text { (sM); thin, weakly } \\
\text { developed } \\
\text { paleosols }\end{array}$ & $\begin{array}{l}\text { Ice-age } \\
\text { cataclysmic } \\
\text { flood }\end{array}$ & $\begin{array}{l}\text { Moderate to high- } \\
\text { energy flood } \\
\text { deposition in areas } \\
\text { marginal to high- } \\
\text { energy flood } \\
\text { currents, including } \\
\text { most of Cold } \\
\text { Creek bar (200 } \\
\text { Area Plateau) }\end{array}$ & $\begin{array}{l}\text { Brownish } \\
\text { gray to olive } \\
\text { gray }\end{array}$ & $40-90$ & $\begin{array}{l}\text { Subangular to } \\
\text { subrounded }\end{array}$ & $\begin{array}{l}\text { Moderate to } \\
\text { well sorted }\end{array}$ & $\begin{array}{l}\text { Low-angle } \\
\text { horizontal } \\
\text { laminations; } \\
\text { normal and } \\
\text { reverse } \\
\text { gradations } \\
\text { (rhythmites); } \\
\text { occasional cut } \\
\text { and fill }\end{array}$ & $2-10$ & Loose & $\begin{array}{l}\text { Consistently } \\
\text { low }\end{array}$ & $\begin{array}{l}\text { "Salt and pepper"- } \\
\text { like appearance; } \\
\text { graded, rhythmic } \\
\text { bedding; clastic dikes; } \\
\text { soft-sediment } \\
\text { deformation along bed } \\
\text { contacts; where } \\
\text { exposed individual } \\
\text { beds can be traced } \\
\text { laterally for tens of } \\
\text { meters or more; } \\
\text { localized minor cut } \\
\text { and fill channels; } \\
\text { occasional rip-up } \\
\text { clasts }\end{array}$ \\
\hline & $\begin{array}{l}\text { Gravel- } \\
\text { dominated } \\
\text { (H1 and H3 } \\
\text { units) }\end{array}$ & Pleistocene & $\begin{array}{l}\text { Sandy gravel } \\
\text { (sG) to silty } \\
\text { sandy gravel } \\
\text { (msG) }\end{array}$ & $\begin{array}{l}\text { Lenses and sheets } \\
\text { of pebbly sand } \\
\text { (gS); fine- to } \\
\text { coarse-grained } \\
\text { sand (S) }\end{array}$ & $\begin{array}{l}\text { Ice-age } \\
\text { cataclysmic } \\
\text { flood }\end{array}$ & $\begin{array}{l}\text { High-energy flood } \\
\text { deposits within } \\
\text { and along } \\
\text { cataclysmic flood } \\
\text { channels }\end{array}$ & $\begin{array}{l}\text { Dark gray, } \\
\text { brownish } \\
\text { gray, to olive } \\
\text { gray }\end{array}$ & $40-90$ & $\begin{array}{l}\text { Subangular to } \\
\text { subrounded }\end{array}$ & $\begin{array}{l}\text { Poor to } \\
\text { moderately } \\
\text { sorted }\end{array}$ & $\begin{array}{l}\text { Horizontal to } \\
\text { large-scale } \\
\text { planar- } \\
\text { tabular (i.e., } \\
\text { foreset) cross- } \\
\text { bedding; cut } \\
\text { and fill }\end{array}$ & $2-5$ & Loose & $\begin{array}{l}\text { Consistently } \\
\text { very low }\end{array}$ & $\begin{array}{l}\text { Basaltic; silt coatings } \\
\text { on gravel clasts; } \\
\text { laterally discontinuous } \\
\text { beds with ubiquitous } \\
\text { cut and fill channels; } \\
\text { unconsolidated, fine- } \\
\text { grained, angular rip- } \\
\text { up clasts common; } \\
\text { boulders, caving hole }\end{array}$ \\
\hline \multirow[t]{2}{*}{ Cold Creek unit } & $\mathrm{CCUz}$ & $\begin{array}{l}\text { Late } \\
\text { Pliocene to } \\
\text { early } \\
\text { Pleistocene }\end{array}$ & $\begin{array}{l}\text { Fine sand } \\
\text { and silt, (S, } \\
\mathrm{mS}, \mathrm{sM}, \mathrm{M})\end{array}$ & $\begin{array}{l}\text { Thin, weakly } \\
\text { developed } \\
\text { paleosols }\end{array}$ & $\begin{array}{l}\text { Fluvial and/or } \\
\text { eolian }\end{array}$ & $\begin{array}{l}\text { Fluvial overbank } \\
\text { to eolian deposits; } \\
\text { mostly limited to } \\
\text { beneath } 200 \text { West } \\
\text { Area }\end{array}$ & $\begin{array}{l}\text { Buff, pale to } \\
\text { dark brown, } \\
\text { olive brown }\end{array}$ & $<5$ & NA & $\begin{array}{l}\text { Well sorted } \\
\text { to very well } \\
\text { sorted }\end{array}$ & $\begin{array}{l}\text { Laminated and } \\
\text { bedded to } \\
\text { massive }\end{array}$ & $5-20$ & $\begin{array}{l}\text { Moderately } \\
\text { to very } \\
\text { strongly } \\
\text { cohesive/ } \\
\text { compact }\end{array}$ & $\begin{array}{l}\text { Consistently } \\
\text { high }\end{array}$ & $\begin{array}{l}\text { Micaceous; weakly to } \\
\text { moderately calcareous }\end{array}$ \\
\hline & CCUg & $\begin{array}{l}\text { Late } \\
\text { Pliocene to } \\
\text { early } \\
\text { Pleistocene }\end{array}$ & $\begin{array}{l}\text { Sandy gravel } \\
\text { (sG) to silty } \\
\text { sandy gravel } \\
\text { (msG) }\end{array}$ & $\begin{array}{l}\text { Well sorted, } \\
\text { medium- to } \\
\text { coarse-grained } \\
\text { sand }(\mathrm{S}) \text { to pebbly } \\
\text { sand }(\mathrm{gS})\end{array}$ & $\begin{array}{l}\text { Mainstream } \\
\text { fluvial }\end{array}$ & $\begin{array}{l}\text { Alluvial deposits } \\
\text { from ancestral } \\
\text { Columbia River } \\
\text { found in central } \\
\text { Pasco Basin near } \\
\text { Southeast } \\
\text { Anticline and } \\
\text { southeast of Gable } \\
\text { Gap }\end{array}$ & $\begin{array}{l}\text { Light gray to } \\
\text { olive gray, } \\
\text { "whitish" or } \\
\text { "bleached" } \\
\text { clast coatings }\end{array}$ & $20-50$ & $\begin{array}{l}\text { Subrounded } \\
\text { to well } \\
\text { rounded }\end{array}$ & $\begin{array}{l}\text { Moderately } \\
\text { sorted, } \\
\text { bimodal }\end{array}$ & $\begin{array}{l}\text { Unknown } \\
\text { because unit is } \\
\text { has only been } \\
\text { described } \\
\text { from drill } \\
\text { cuttings, } \\
\text { which do not } \\
\text { preserve } \\
\text { sedimentary } \\
\text { structure }\end{array}$ & $0-5$ & $\begin{array}{l}\text { Loose to } \\
\text { weakly } \\
\text { compacted } \\
\text { and//or } \\
\text { cemented }\end{array}$ & $\begin{array}{l}\text { Consistently } \\
\text { low to } \\
\text { moderate }\end{array}$ & $\begin{array}{l}\text { Multilithic gravels; } \\
\text { unaltered to slightly } \\
\text { altered, locally } \\
\text { carbonate cemented; } \\
\text { open hole possible }\end{array}$ \\
\hline \multirow[t]{2}{*}{$\begin{array}{l}\text { Ringold } \\
\text { Formation }\end{array}$} & Coarse & $\begin{array}{l}\text { Miocene to } \\
\text { Pliocene }\end{array}$ & $\begin{array}{l}\text { Sandy gravel } \\
\text { (sG) to silty } \\
\text { sandy gravel } \\
\text { (msG) }\end{array}$ & $\begin{array}{l}\text { Gravelly sand } \\
\text { (gS) to sand (S) }\end{array}$ & $\begin{array}{l}\text { Mainstream } \\
\text { fluvial }\end{array}$ & $\begin{array}{l}\text { Alluvial channel } \\
\text { and crevasse-splay } \\
\text { deposits }\end{array}$ & $\begin{array}{l}\text { Rusty brown, } \\
\text { orange, or } \\
\text { yellow }\end{array}$ & 0 to $10 \%$ & $\begin{array}{l}\text { Subrounded } \\
\text { to well } \\
\text { rounded }\end{array}$ & $\begin{array}{l}\text { Moderately } \\
\text { sorted, } \\
\text { bimodal }\end{array}$ & $\begin{array}{l}\text { Bedded to } \\
\text { massive }\end{array}$ & $0-3$ & $\begin{array}{l}\text { Weakly to } \\
\text { semi- } \\
\text { consolidated }\end{array}$ & Variable & $\begin{array}{l}\text { Weathering rinds, } \\
\text { clay skins, } \\
\text { multilithic; pervasive } \\
\text { rusty brown color, } \\
\text { felsic matrix; open } \\
\text { hole common }\end{array}$ \\
\hline & Fine & $\begin{array}{l}\text { Miocene to } \\
\text { Pliocene }\end{array}$ & $\begin{array}{l}\text { Clay (C) to } \\
\text { silt (Z) }\end{array}$ & $\begin{array}{l}\text { Sand lenses, } \\
\text { paleosols }\end{array}$ & $\begin{array}{l}\text { Fluvial- } \\
\text { lacustrine }\end{array}$ & $\begin{array}{l}\text { Overbank alluvial } \\
\text { or lake }\end{array}$ & $\begin{array}{l}\text { Brown, } \\
\text { orange, } \\
\text { yellow to } \\
\text { gleyed grey, } \\
\text { olive, green, } \\
\text { or blue }\end{array}$ & 0 & $\mathrm{~N} / \mathrm{A}$ & $\begin{array}{l}\text { Well sorted to } \\
\text { very well } \\
\text { sorted }\end{array}$ & $\begin{array}{l}\text { Laminated to } \\
\text { massive }\end{array}$ & $0-15$ & $\begin{array}{l}\text { Cohesive and } \\
\text { compact }\end{array}$ & $\begin{array}{l}\text { Consistently } \\
\text { high }\end{array}$ & Gleyed color \\
\hline
\end{tabular}




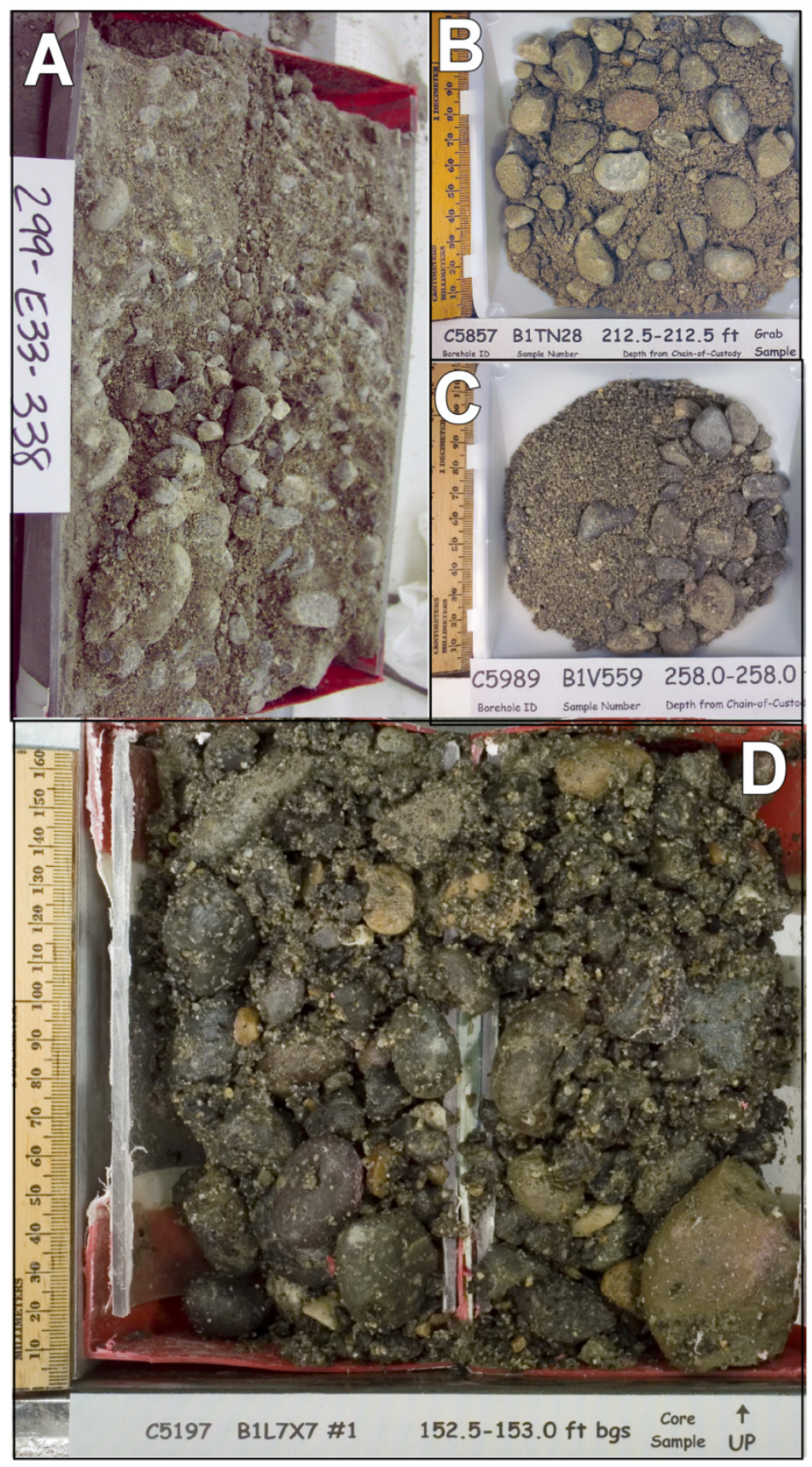

GG.CCUg.png

Figure 4.5. Gravel-dominated facies of the Cold Creek unit (CCUg) from boreholes in the vicinity of Gable Gap. A) Grayish brown, silty sandy gravel in core from well 299-E33-338; $233 \mathrm{ft}$ (71 m) depth. B) Comparable drill cuttings from well 299-E33-342; $212.5 \mathrm{ft}(65 \mathrm{~m})$ depth. C) 299-E33-205; $258 \mathrm{ft}(78 \mathrm{~m})$ depth). D) 699-50-56; $153 \mathrm{ft}(47 \mathrm{~m})$ depth. Note the general lack of consolidation and moderate amount of basalt in the sand fraction. The few very well rounded and polished pebbles and cobbles are likely older, reworked Ringold Formation clasts.

Silt-Dominated Subunit (CCUz). A locally thick, silt-dominated sequence preserved in Gable Gap is dissimilar to either the Ringold Formation or the overlying Hanford formation. Drill samples show the 
unit to be well-sorted, weakly stratified silt to micaceous, silty fine sand (Figure 4.6). Colors are various shades and combinations of olive and brown. Calcareous horizons within the unit appear to represent periods of calcic soil development during accumulation of the strata. Owing to the high silt content, the CCUz subunit is generally cohesive and compact, which likely prevented complete disintegration and erosion by Ice Age floods. This subunit is interpreted to represent deposition within an overbank-fluvial environment, associated with the ancestral Columbia River. Massive intervals in the CCUz may also be present, suggesting eolian deposition may also have occurred locally. These silt-dominated deposits could be equivalent or partially equivalent to the similar-appearing deposits of the Cold Creek unit that overlie the calcrete horizon(s) (Cold Creek unit - caliche [CCUc] facies) in the 200 West Area (DOE/RL 2002).

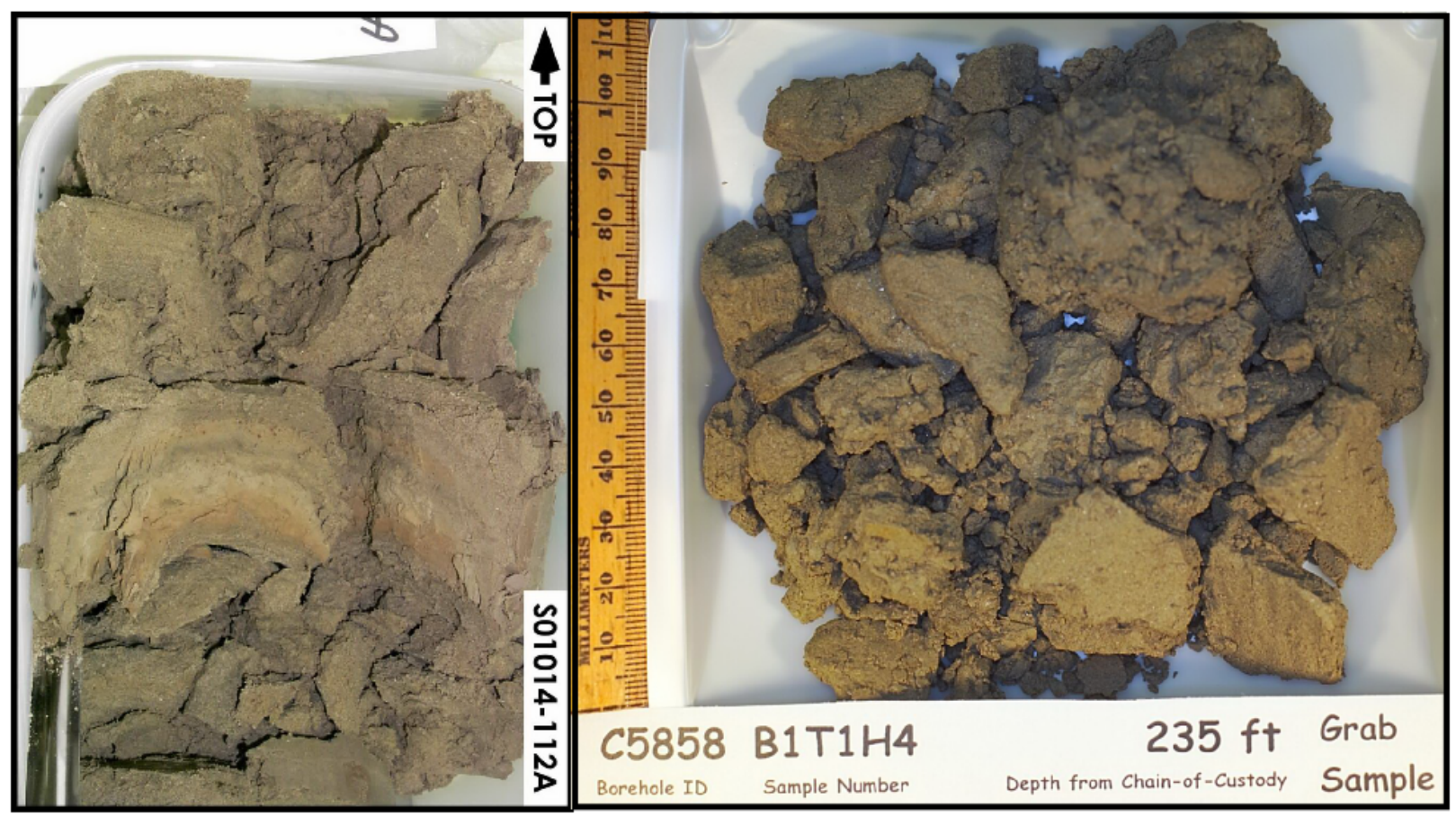

GG.CCUz.png

Figure 4.6. Cold Creek unit silt (CCUz). Left: Percussion core of micaceous, olive-brown, laminated silt from borehole 299-E33-45; $224 \mathrm{ft}(68 \mathrm{~m})$ depth. Note: Original stratification of drabcolored silt still preserved. Right: Drill cuttings of compact and cohesive CCUz from borehole 299-E33-343; $235 \mathrm{ft}$ (72 m) depth.

The CCUz subunit exists as an unusual, elongated buried mound that begins near the B Tank Farm in the northern 200 East Area and trends northwest toward Gable Gap (Figures 4.7, A.2, A.5, B.5, and C.6). The buried mound is elongated parallel to the direction as the floodwaters that swept through Gable Gap, suggesting the mound may be a streamlined landform molded by the floods. Similar streamlined landforms are a common occurrence on the surface of the Channeled Scabland (Figure 4.8) where the floods eroded through the silt-dominated Palouse Formation (Baker 1978). Minor beds of sand may also occur within the CCUz, especially in the thicker, silt-dominated sequences (see Figure 2.2). 


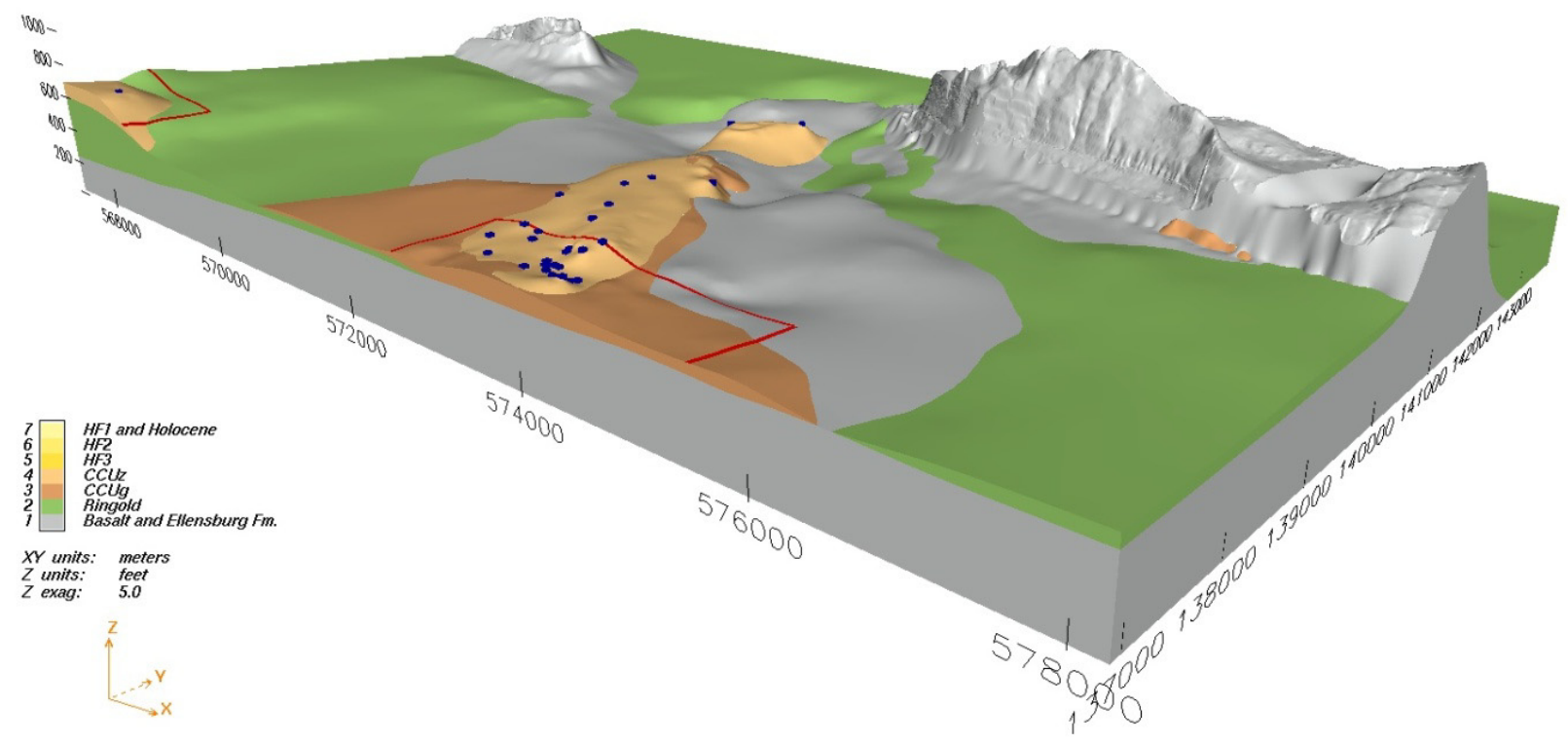

Figure 4.7. EarthVision ${ }^{\circledR}$ model showing the mound-like form of the Cold Creek silt (CCUz) subunit extending south from Gable Gap. View looking northwest. Vertical exaggeration $=5 \mathrm{X}$.

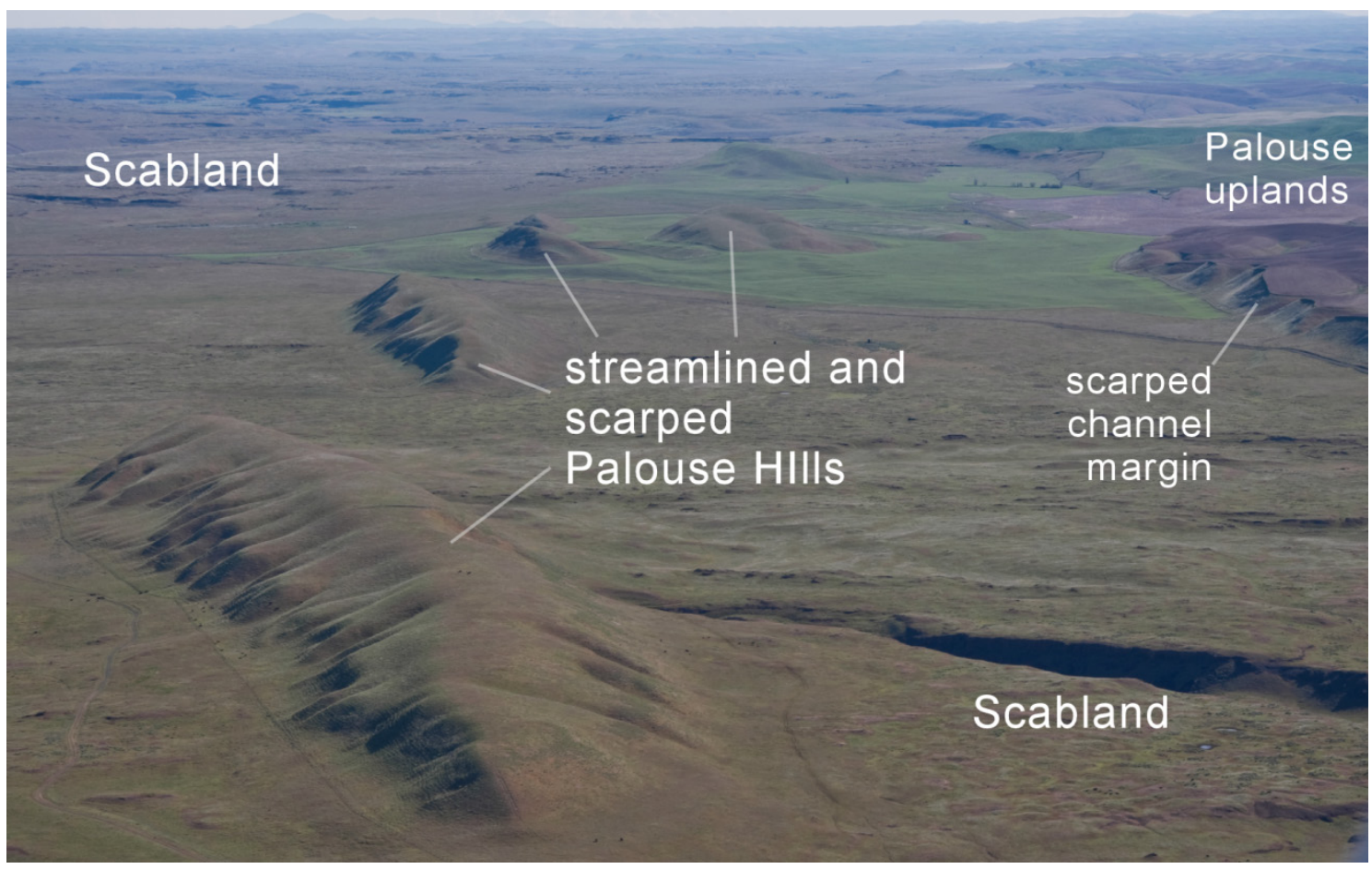

Figure 4.8. Example of high-relief, streamlined and scarped hills of silty Palouse Formation located in the eastern Channeled Scabland. Ice Age floods, moving toward viewer in this image, eroded through a once-continuous blanket of windblown silt, leaving behind these streamlined remnants. The streamlined hills rest on basalt bedrock, eroded into scabland by the floods. These are analogous to the elongated, isolated ridge of Cold Creek unit silt (CCUz) buried near Gable Gap (see Figure B.5 and C.6). 
The transition from the mainstream fluvial gravel facies (CCUg) to overbank facies (CCUz) during the Cold Creek period may signify the shift of the Columbia River out of Gable Gap northward toward the horn of the Columbia River. Such a shift may have been the result of ongoing tectonic uplift along the Umtanum Ridge-Gable Mountain anticline, which perhaps defeated the river and forced it northward towards the end of Cold Creek time.

\subsubsection{Hanford Formation}

The Hanford formation in the vicinity of Gable Gap is subdivided into either 1) gravel-dominated, or 2) sand-dominated lithofacies, which transition laterally into one another depending on distance from the main, high-energy flood currents (see Figure 3.3).

1. Gravel-Dominated Lithofacies. This facies generally consists of coarse-grained basaltic sand and granule to boulder gravel. These deposits display an open framework texture, massive bedding, plane to low-angle bedding, and large-scale planar cross bedding in outcrop. Gravel-dominated beds sometimes grade upward into thinner, laterally discontinuous beds of sand- and/or silt. Gravel clasts are dominantly basalt with lesser amounts of mostly reworked Ringold Formation clasts, including granite, quartzite, and gneiss. In the Gable Gap study area, two gravel-dominated sequences are recognized-the $\mathrm{H} 3$ and $\mathrm{H} 1$ units.

2. Sand-Dominated Lithofacies. This facies consists of fine- to coarse-grained sand and granule gravel. The sands typically consist of $40-90 \%$ basaltic rock fragments (Table 4.1). They may contain small pebbles and rip-up clasts, pebble-gravel interbeds, and often grade upward into thin $(<1 \mathrm{ft}[0.3 \mathrm{~m}])$ zones of silt-dominated facies. Sand-dominated facies commonly display plane lamination and bedding, and less commonly, channel cut-and-fill sequences. The facies transitions laterally into gravel-dominated facies northward into Gable Gap. In the Gable Gap study area, only a single thick sand-dominated sequence (H2 unit) is recognized in the southern portion of the study area (Figures A.2, B.2, and C.3).

The higher basalt content for the Hanford formation is due to the flow path of the Ice Age floodwaters, which passed over the purely basaltic terrain of the Columbia Plateau (e.g., Channeled Scabland). In contrast the origin for the older strata of the Ringold and Cold Creek units were derived from rivers draining over non-basaltic rocks around the perimeter of the plateau. This mineral assemblage gives the Hanford formation its distinctive "salt and pepper" appearance, often noted in drillers' and geologists' logs.

The Hanford formation in the Gable Gap area is informally subdivided into three main subunits: H1, $\mathrm{H} 2$, and $\mathrm{H} 3$. The $\mathrm{H} 2$ unit is the sand-dominated sequence, which frequently separates upper and lower gravel-dominated flood sequences. The $\mathrm{H} 2$ unit is generally restricted to the southern third of the study area (Figure C.3), where it is almost $200 \mathrm{ft}(61 \mathrm{~m})$ thick. This unit rapidly transitions into the graveldominated H1 unit northward, where floodwaters increased in velocity through Gable Gap.

It is important to note that $\mathrm{H} 1, \mathrm{H} 2$, and $\mathrm{H} 3$ units are purely lithostratigraphic units and NOT timestratigraphic units-thus, they are flood facies that may have been deposited simultaneously or may represent a composite of similar facies from different flood events. From one place to another, the type of sediment deposited was strongly dependent on its location relative to the changing energy level of the floods, which transitioned laterally from high energy to lower energy southward to southeastward through 
Gable Gap. Thus, the H1, H2, and H3 units recognized in the Gable Gap area do not necessarily correlate with similarly named units of the Hanford formation recognized elsewhere within the Hanford Site.

Lower Gravel-Dominated Sequence (H3 Unit). The Hanford formation lower gravel-dominated sequence is only present in the extreme southern and western margin of the study area (Figure C.4). It consists of predominantly gravelly sand with some gravel and sandy gravel. The basaltic gravels are poorly sorted and subrounded to subangular. The pebble-to-boulder gravels are clast- to matrix-supported with an occasional open-framework fabric, with massive bedding, horizontal to low-angle bedding, and cross-bedding. The H3 unit was likely deposited during one or more of the earlier floods that created Cold Creek Bar as it prograded toward the east and south. Where the CCUz subunit is missing, it may be difficult to distinguish the $\mathrm{H} 3$ unit of the Hanford formation from gravel-dominated facies of the Cold Creek unit (CCUg).

Sand-Dominated Sequence (H2 Unit). The H2 unit consists of predominantly sand-dominated facies of the Hanford formation (Figure 4.9). Internally, this sequence probably contains multiple-graded beds of plane- to foreset-bedded sand or gravelly sand several or more feet thick, which sometimes grade upward into silty sand or silt similar to that observed in Figure 4.9B (see also Figure 4.1). The H2 unit is described on borehole logs of cuttings from the study area as silty sand, sand, and slightly gravelly sand. A total of $40-90 \%$ of the grains are dark basalt; the remainder are mostly light-colored quartz and feldspar, giving the characteristic "salt and pepper" appearance. Calcium carbonate occurs in the Hanford formation sand-dominated sequence as disseminated grains of detrital caliche or calcite to weakly weathered zones containing secondary carbonate filaments and/or nodules. The amount of calcium carbonate is generally small—usually less than $1 \mathrm{wt} \%$.

Sandy beds may be fine and grade upward into thin beds of sandy silt to silt (see Figures 4.9B and 4.1); graded beds such as these are sometimes referred to as "rhythmites." Each rhythmite may represent the deposition from a separate flood (Waitt 1980, 1985; Smith 1993), or perhaps surges from a single flood (Bjornstad 1980, Baker et al. 1991). Most rhythmites go undetected in boreholes; however, because drill cuttings are generally collected at 5-ft intervals, the scale of the rhythmic bedding is much finer. Therefore, many more silt-capped rhythmites may be present in the subsurface than are reported in drillers' and geologists' logs.

Within the study area the Hanford formation sand-dominated sequence (H2 unit) is limited to the area south of Gable Gap (see Figure C.3). Here, the flow of the Ice Age floods expanded beyond the confines of Gable Gap where flood currents slowed, allowing for the deposition of predominantly sand. The structure-contour map of the top of the Hanford formation H2 unit (Figure B.2) shows that the Hanford formation sand sequence is thickest (almost $200 \mathrm{ft}[61 \mathrm{~m}]$ ) beneath Cold Creek Bar along the southern boundary of the study area and quickly pinches out north of Cold Creek Bar. Figure B.2 shows an unusual finger of the $\mathrm{H} 2$ unit that protrudes north a short distance toward the gap. The finger of sand may have been deposited in the slightly quieter water that existed between two buried flood channels flowing through Gable Gap and then modified (eroded) by later floods.

Upper Gravel-Dominated Sequence (H1 Unit). The Hanford formation upper gravel sequence (H1 unit) covers all of the study area except for the elevated basalt ridges of Gable Mountain and Gable Butte (Figure C.2). Poorly sorted mixtures of silty sandy basaltic gravel textures in the H1 unit are similar to those of the H3 unit. The loose, gray to brownish gray sediments are typically fresh appearing with little or no observed weathering or alteration (Figure 4.10). 


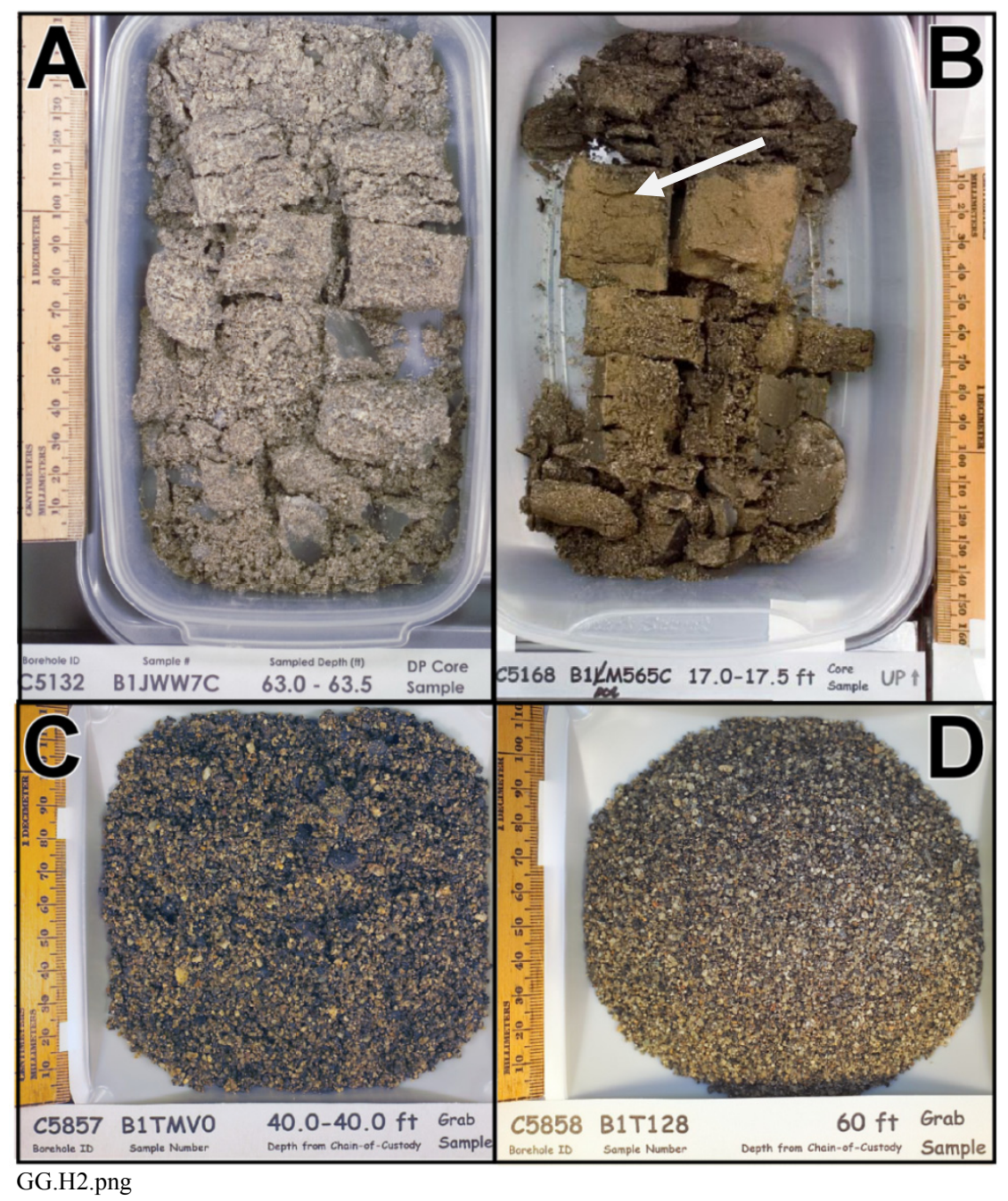

Figure 4.9. Hanford formation $\mathrm{H} 2$ unit in 200 East Area. A) Laminated, "salt and pepper" sands from $63 \mathrm{ft}(19 \mathrm{~m})$ depth in direct push core from C5132, BX Tank Farm. B) Direct-push core 17 $\mathrm{ft}(5 \mathrm{~m})$ depth from C5168, B Tank Farm. Notice graded-bed contact between flood rhythmites; brown silt marks the top of one rhythmite (arrow), overlain by coarse sand at the base of the succeeding flood rhythmite. C and D) Drill cuttings of typically loose, moderately sorted, medium- to coarse-grained, basaltic sand in wells 299-E33-342 and -343, respectively.

Basalt boulders are another characteristic of the coarse-grained Hanford formation, both within the $\mathrm{H} 1$, as well as the $\mathrm{H} 3$ units. Boulder-sized clasts ( $>10$ in. [256 mm] diameter) are rarely-if ever-reported for either the Ringold Formation or the Cold Creek unit. Unlike huge Ice Age floods, normal rivers are not swift enough to transport boulder-sized clasts; boulders are therefore diagnostic of the Hanford formation.

Based on observations of outcrop (see Figure 4.1) and intact core samples, the Hanford formation upper gravel sequence is interpreted to consist of the high-energy, gravel-dominated facies with discontinuous lenses of the sand-dominated facies. Occasionally, silt-lenses are draped between flood sequences, but these constitute a relatively small percentage of the total volume of the H1 unit. Within 
the Gable Gap study area, this unit is well exposed in the northeast corner of the 200 East Area in the 50$\mathrm{ft}$ (15-m) deep 218-E-12B Burial Ground (Figure 4.11).

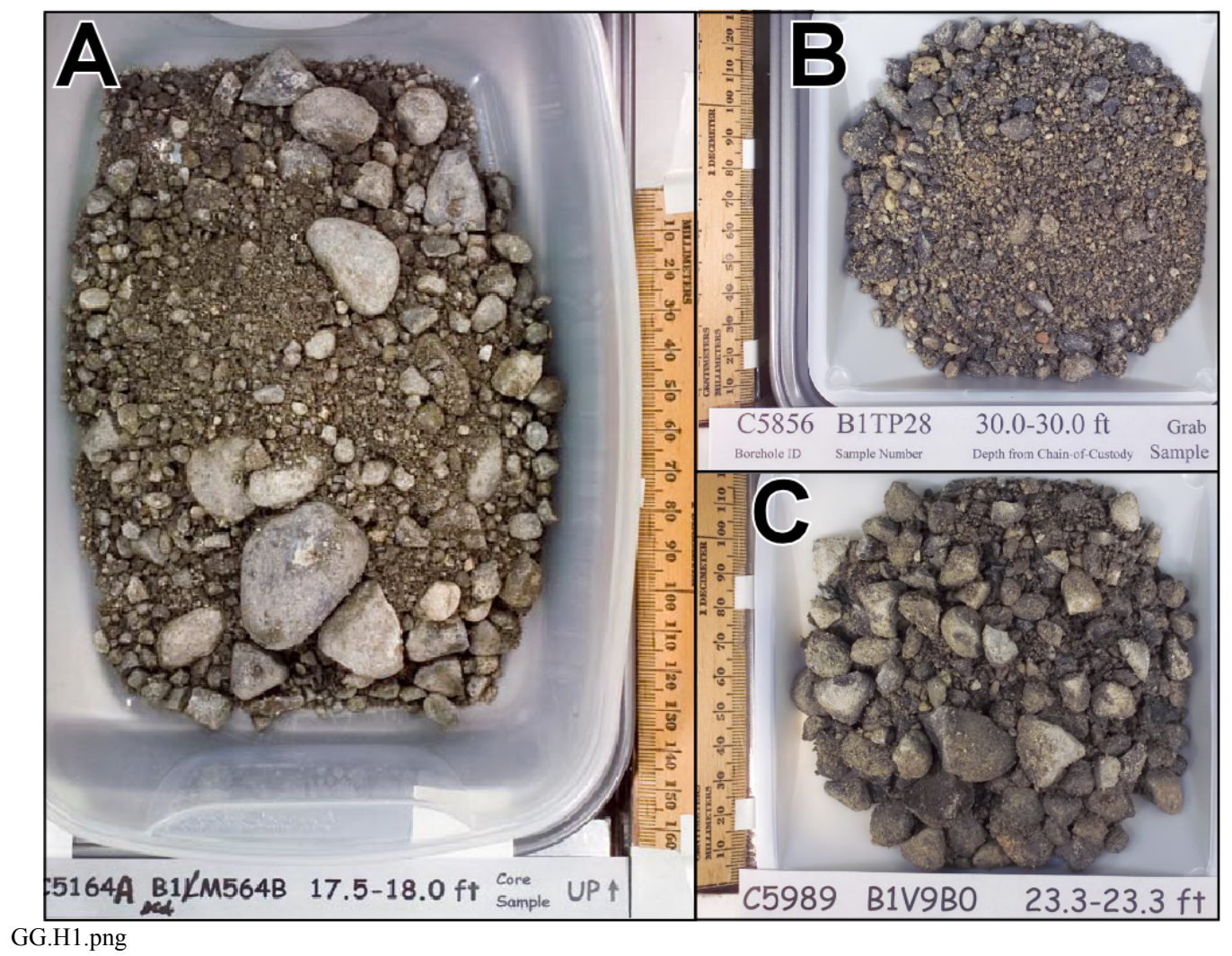

Figure 4.10. Hanford formation $\mathrm{H} 1$ unit from the B-BX-BY Tank Farm, 200 East Area. The H1 unit is a loose, gravel-dominated, poorly to moderately sorted unit composed of mostly unweathered, subangular basalt rock fragments in a matrix of sand and silt. A) Boring C5164; B) 299-E33-341; and C) 299-E33-205.

\subsubsection{Holocene Deposits}

Holocene deposits within the study area consist of up to 30-50 ft (10-15 m) of backfill material within tank farms, cribs, and trenches located in the northern 200 East Area. This backfill material is composed mostly of gravel-dominated deposits of the Hanford formation H1 unit removed during construction of the waste facilities. In places, such as the BY Tank Farm within the north-central 200 East Area, all the Hanford formation H1 unit was removed and replaced with backfill (e.g., see Figure B.1). Thin (few feet [1-2 m]) sheets of eolian sand also locally cover the surface. Holocene-age debris in the form of slopewash and talus has also been shed off the higher-relief slopes of Gable Mountain and Gable Butte. 


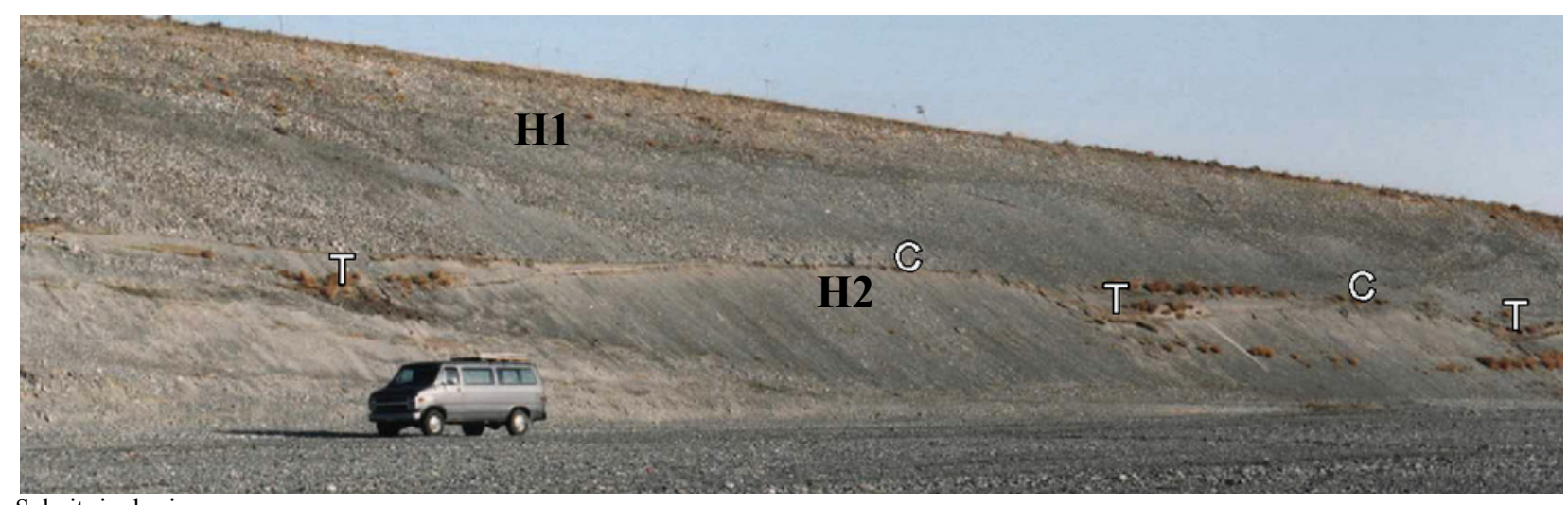

Subpit.ripples.jpg

Figure 4.11. Outburst-flood deposits of the Hanford formation exposed along the north wall of the 218-E-12B Burial Ground located along the north flank of the Cold Creek Flood Bar (Wood et al. 2000; Bjornstad 2006). The upper half of the exposure is composed of graveldominated (H1) flood deposits, underlain by sand-dominated (H2) deposits of the Hanford formation. In between are a series of buried, long-amplitude, giant current ripples; ripple crests are indicated by the letter "C" and ripple troughs by the letter "T." Slackwater deposits of silt (indicated by vegetation growth) drape over the ripples, thickening in the ripple troughs and thinning over the crests.

\subsubsection{Clastic Dikes}

Clastic dikes are vertical to subvertical sedimentary structures that crosscut normal sedimentary layering, especially in Ice-Age flood deposits of the Hanford formation (Black 1979; Fecht and Weekes 1996; Fecht et al. 1999). The dikes are believed to result from dewatering of saturated, rapidly deposited sediment and/or hydraulic injection into overlying sediment layers associated with sudden lowering of flood levels immediately following Ice Age flood events. Clastic dikes are common to the sanddominated facies of the Hanford formation, but rarely identified in the gravel-dominated facies based on observations of outcrop exposures. Thus, clastic dikes may be mostly absent in the Gable Gap study area except along the southern boundary where up to $200 \mathrm{ft}(61 \mathrm{~m})$ of the sand-dominated Hanford formation $\mathrm{H} 2$ unit is located (Figure C.3). 


\subsection{Structure}

Structural features in the vicinity of Gable Gap include first- and second-order folds, as well as faults (Figure 5.1) associated with the Yakima Fold Belt (YFB). East-west trending ridges of the YFB resulted from tectonism via north-south compression of Earth's crust since the Miocene Epoch (Reidel and Fecht 1981; DOE 1988). Structures exposed at the surface were mapped by Fecht (1978) and Myers and Price (1979); subsurface structures are inferred from the basalt units and elevations of top of basalt in geologic cross sections (Appendix A). Subsurface structures have also been interpreted based on a combination of geophysical techniques, including magnetic, gravity, and seismic-reflection surveys (Ault 1981; Repasky et al. 2009). Most recently, the structural relief on the top of basalt between known points (i.e., boreholes) in Figure 2.5 was interpolated from an integration and re-evaluation of the seismic-reflection data.

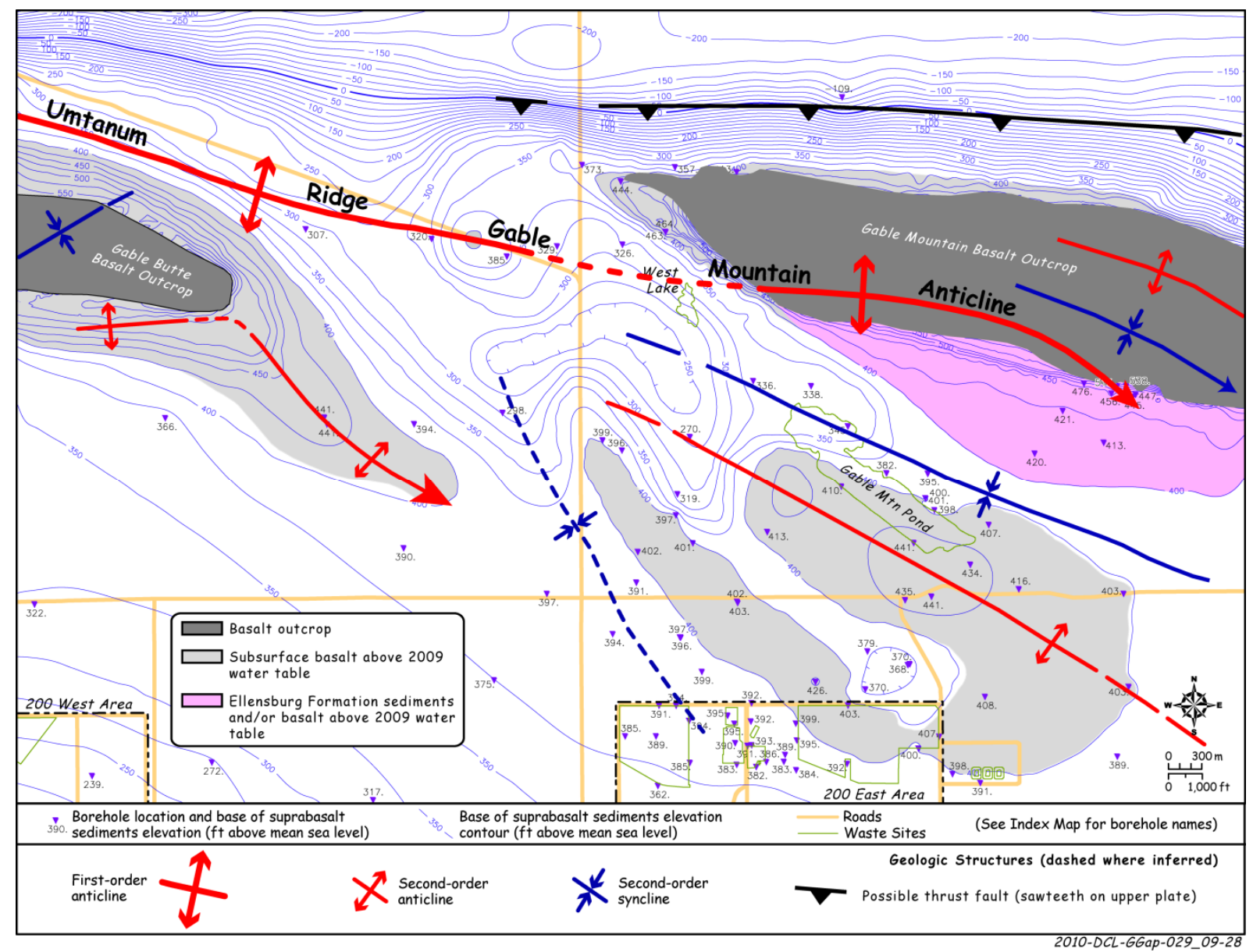

Figure 5.1. Geologic structures in the vicinity of Gable Gap. Compiled from surface and subsurface maps in Fecht (1978), Ault (1981), Myers and Price (1979), and Graham et al. (1984).

Gable Gap lies along a major first-order structure (Umtanum Ridge-Gable Mountain anticline) of the YFB. Gable Gap formed between two, second-order, en echlon, asymmetric folds (Gable Mountain and Gable Butte) superimposed onto the larger structure. Overall, the first-order structures appear to plunge downward to the southeast (Figure 5.1). A series of en echelon folds lies along either side of the 
first-order Gable Butte-Gable Mountain anticline (Myers and Price 1979; Ault 1981). From the upfolded ridges, the top of basalt dips north into the Wahluke syncline and south into the Cold Creek syncline.

In general, basalt flows and the overlying suprabasalt sediments thicken to the north and south into the synclinal basins. In addition, sedimentary interbeds of the Ellensburg Formation thin or disappear over the anticlinal ridges, indicating these structures were actively growing during eruption and emplacement of Columbia River basalt flows. Cumulative deformation on the suprabasalt sediments suggest development of the Yakima Folds has continued at a long-term, low-average rate to the present (Reidel 1984; DOE 1988).

At Gable Mountain, the more fractured hinge area and steeper south limb of the fold were preferentially eroded away during massive Ice Age floods (Figures 5.1 and 5.2). Considerable relief appears to exist in the subsurface on the top of basalt north of Gable Mountain, some of which may be the result of a high-angle reverse and/or thrust fault in this region. Reverse or thrust faults commonly develop on the steeper, overstrained sections of other Yakima folds (Myers and Price 1979).

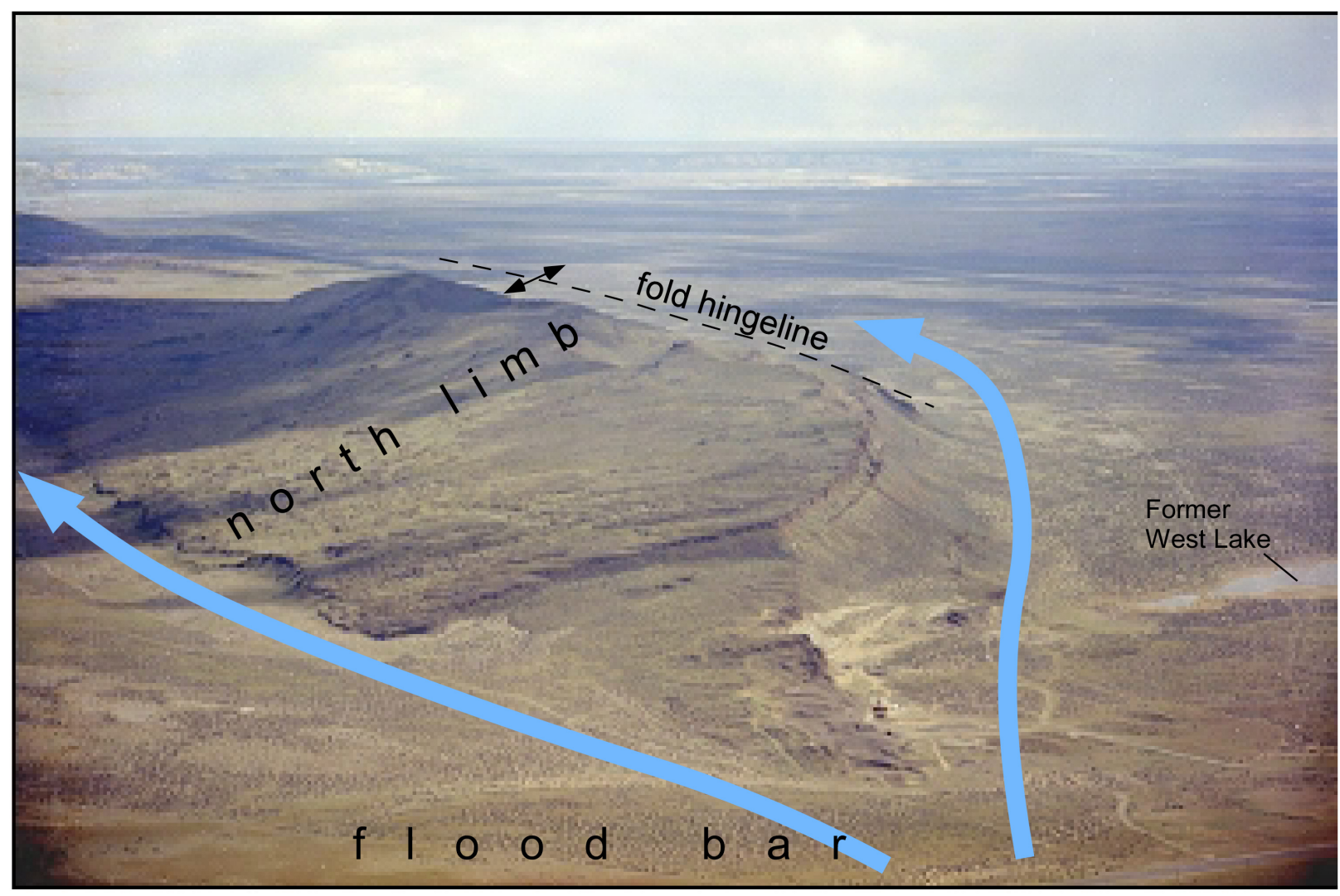

Figure 5.2. Flood-swept, hogback ridge of western Gable Mountain, looking southeast. Low-angle (10-20 degree) tilt of the Columbia River basalt flows show prominently along the gentler north limb of the anticline. Ice Age flood channels (blue arrows) run along both sides of Gable Mountain. Floods racing down the right side of the ridge completely removed the hingeline and steeper south limb of the anticline, leaving only the north limb exposed as a hogback. The largest Ice Age floods rose another $100 \mathrm{ft}(30 \mathrm{~m})$ over the ridge crest. A number of other Ice Age flood landforms, including channels and potholes, lie buried within Gable Gap, located in the foreground. 


\subsection{Geomorphology}

Landforms in the Gable Gap area are primarily the result of structural deformation and cataclysmic Ice Age floods (Fecht 1978), the earliest of which occurred 1 to 2 million years ago (Bjornstad et al. 2001). Outburst floods continued intermittently until about 14,000 to 15,000 years ago (Bjornstad 2006). Little or no change has occurred to the land surface since that period except for localized eolian (i.e., wind) reworking of flood deposits and manmade constructional activities. Figure 1.1 shows the major landforms surrounding the Gable Gap study area and Figure 6.1 as an EarthVision ${ }^{\circledR}$ model representation of the surface topography within the study area.

Gable Gap lies along the northern flank of Cold Creek Bar, a large compound flood bar formed during cataclysmic, Ice-Age floods (see Figure 3.3). The upper surface of the bar in the 200 East Area forms a broad plain at about $700 \mathrm{ft}(210 \mathrm{~m}$ ) elevation, otherwise known as the "Central Plateau" (see Figure 1.1). The bar extends westward for several miles; the northern boundary of the bar is flanked by a series of younger northwest-southeast trending flood channels (Fecht 1978; DOE 1988).

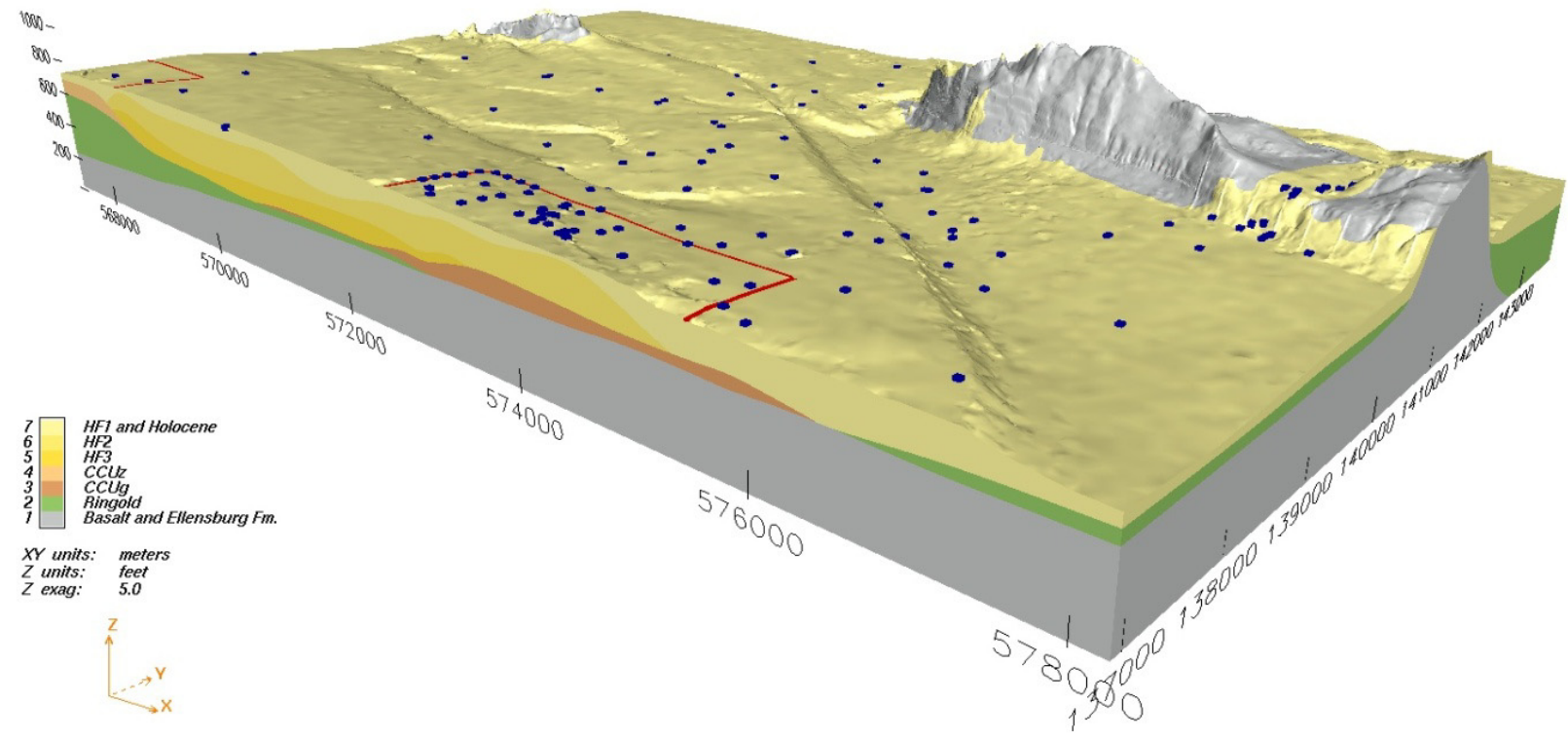

Figure 6.1. EarthVision ${ }^{\circledR}$ model of the present-day surface topography within the Gable Gap study area. Oblique view looking northwest. Vertical exaggeration $=5 \mathrm{X}$.

\subsection{Late-Pleistocene Flood Channels and Bars}

Multiple channels and bars from the last Ice Age floods trend northwest to southeast through Gable Gap. Bars and channels of at least three different ages are preserved in this location. The oldest preserved flood surface is Cold Creek Bar (north end of which is represented by " $B$ " in Figure 6.2). Cold Creek Bar developed as flood deposits prograded to Gable Gap from the eastern end of Umtanum Ridge (see Figure 3.3). North of Cold Creek Bar, later smaller floods (or later stages of the last flood) that did not flood Cold Creek Bar created the "south terrace" and "north bar" geomorphic surfaces ("C"). These surfaces were last incised by the most recent flood (i.e., Lake Columbia flood) that created the West Lake 
channel and scour depressions at the head of Gable Mountain ("D"). This last flood that created the West Lake channel occurred sometime between 14,000-15,000 calendar years ago (Bjornstad 2006).

The oldest surfaces (indicated with the letter "A" in Figure 6.2) are the basalt uplands of Gable Mountain and Gable Gap. All subsequent landforms developed during Ice Age flooding, starting with Cold Creek Bar ("B"). Floods decreased in size toward the end of the Ice Age; these floods were responsible for the development of the south terrace and north bar ("C"). A secondary, sinuous flood channel (dashed arrow) appears to have developed atop the south terrace during the end of a flooding event. The south terrace and north bar, once connected, were subsequently incised by the last flood(s) that created the West Lake and north channels ("D"). Several depressions were also scoured out around the nose of Gable Mountain by the last of the floodwaters that squeezed through these channels.

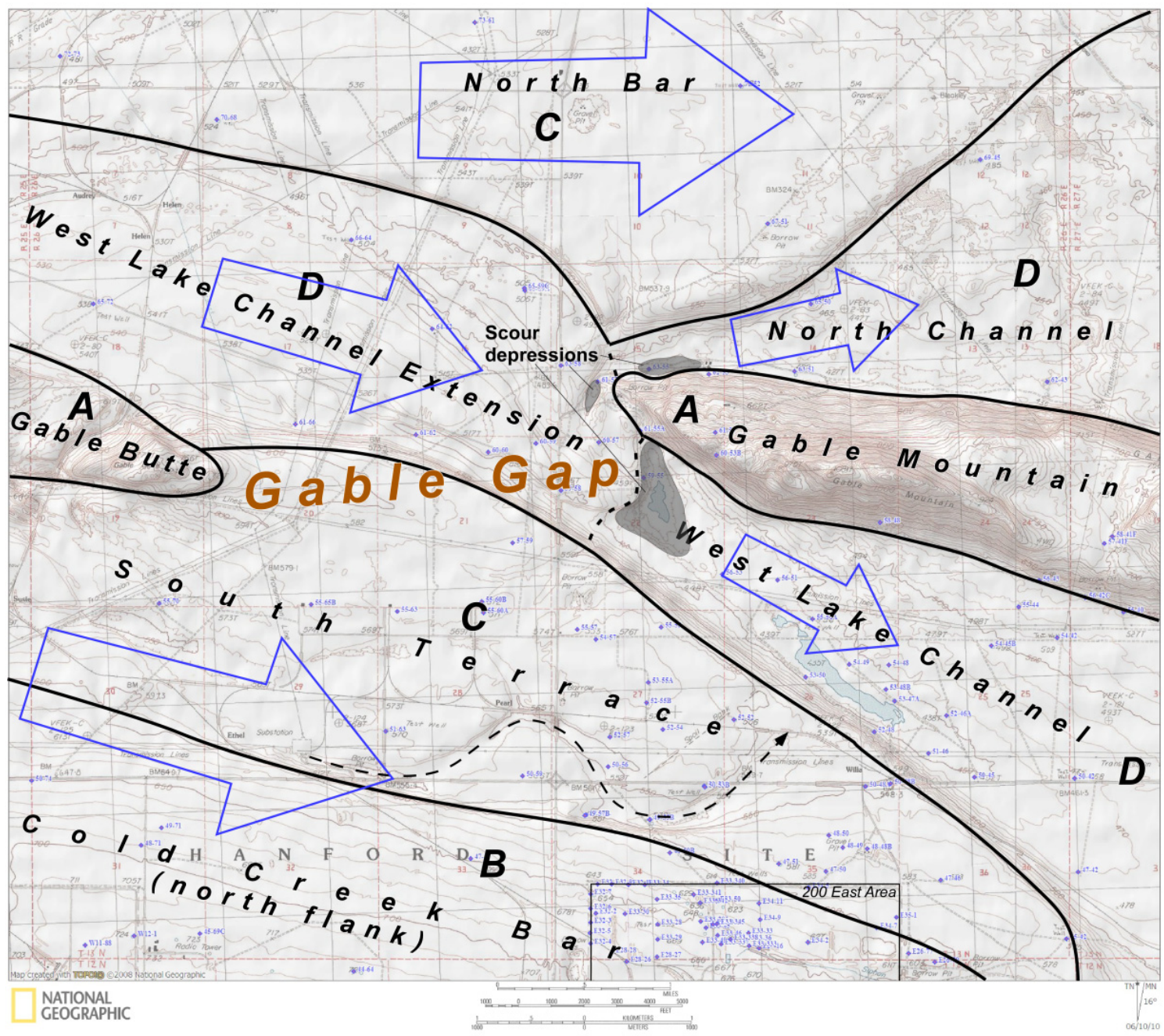

Figure 6.2. Surface-geomorphic map of the Gable Gap study area. Entire area was underwater during multiple Ice Age floods. Block arrows show general flow direction for the last Pleistocene megafloods through Gable Gap. 


\subsection{Buried Paleochannels}

Multiple paleochannels lie within Gable Gap area (Figure 6.3) buried beneath younger flood deposits of the Hanford formation. Locations for these channels are inferred from dozens of boreholes and seismic-reflection data collected within Gable Gap. The age of a paleochannel can be inferred based on the age of the sediments that fills the base of the channel. At least one channel (Channel F) was formed during Ringold time since it holds remnants of the Ringold Formation preserved within it. The remaining five paleochannels (A through E) are filled with coarse-grained, highly permeable flood deposits of the Hanford formation. These paleochannels may have initially formed during Ringold time, but if so, were further deepened during cataclysmic flooding, which removed all Ringold-age deposits from the channel. Paleochannel D, which has a remnant of Ringold Formation along its east side, might be an example of a Ringold-age channel that was cut deeper during Ice Age flooding. Figure 6.4 shows an example of the types of extreme erosion that can occur associated with Ice Age flooding, analogous to the erosional environment of Gable Gap.

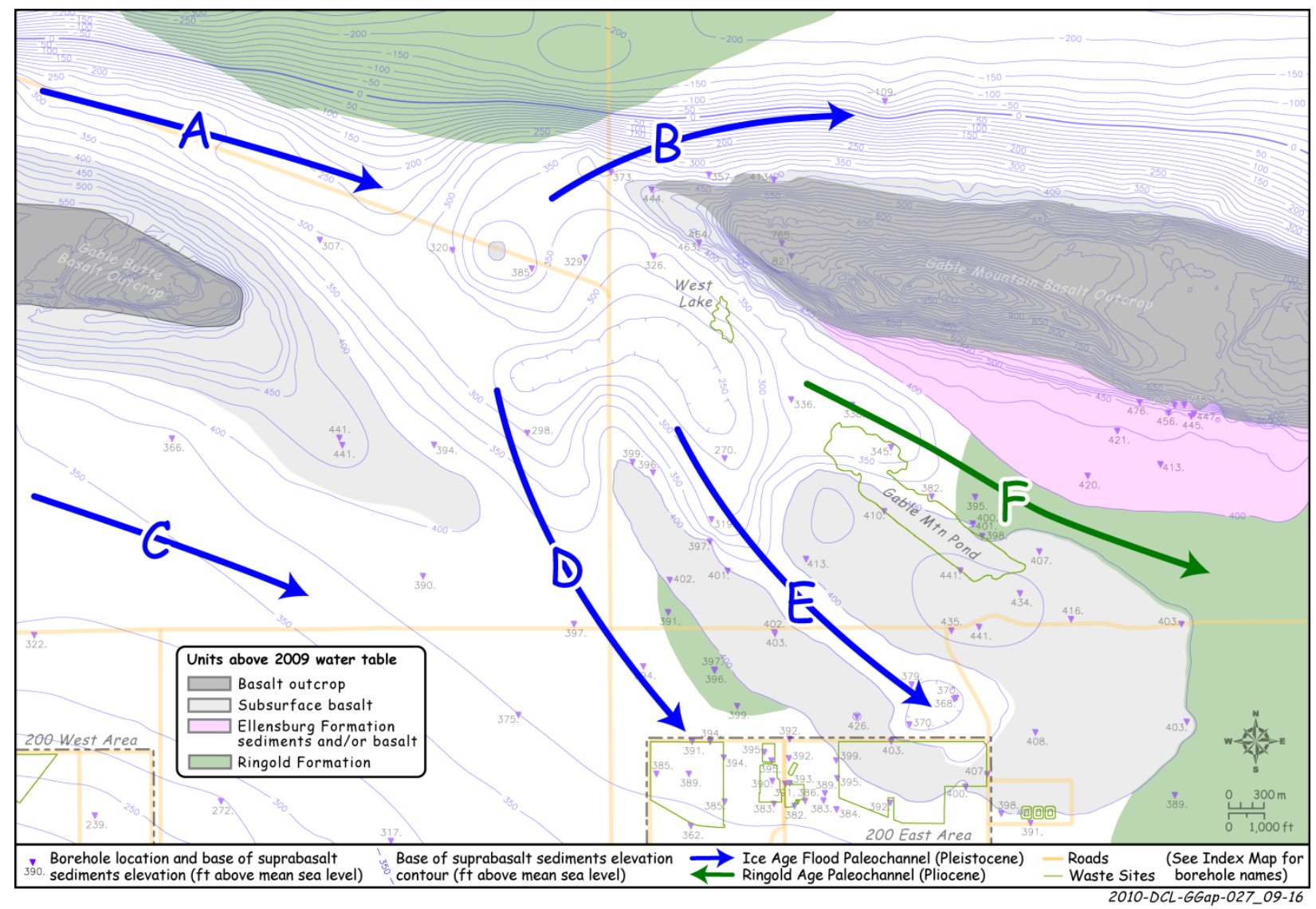

Figure 6.3. Buried paleochannels within the Gable Gap area. Most of the channels were carved out during Pleistocene Ice Age floods, except for Channel F, which was created prior to backfilling with deposits of the Pliocene Ringold Formation. 


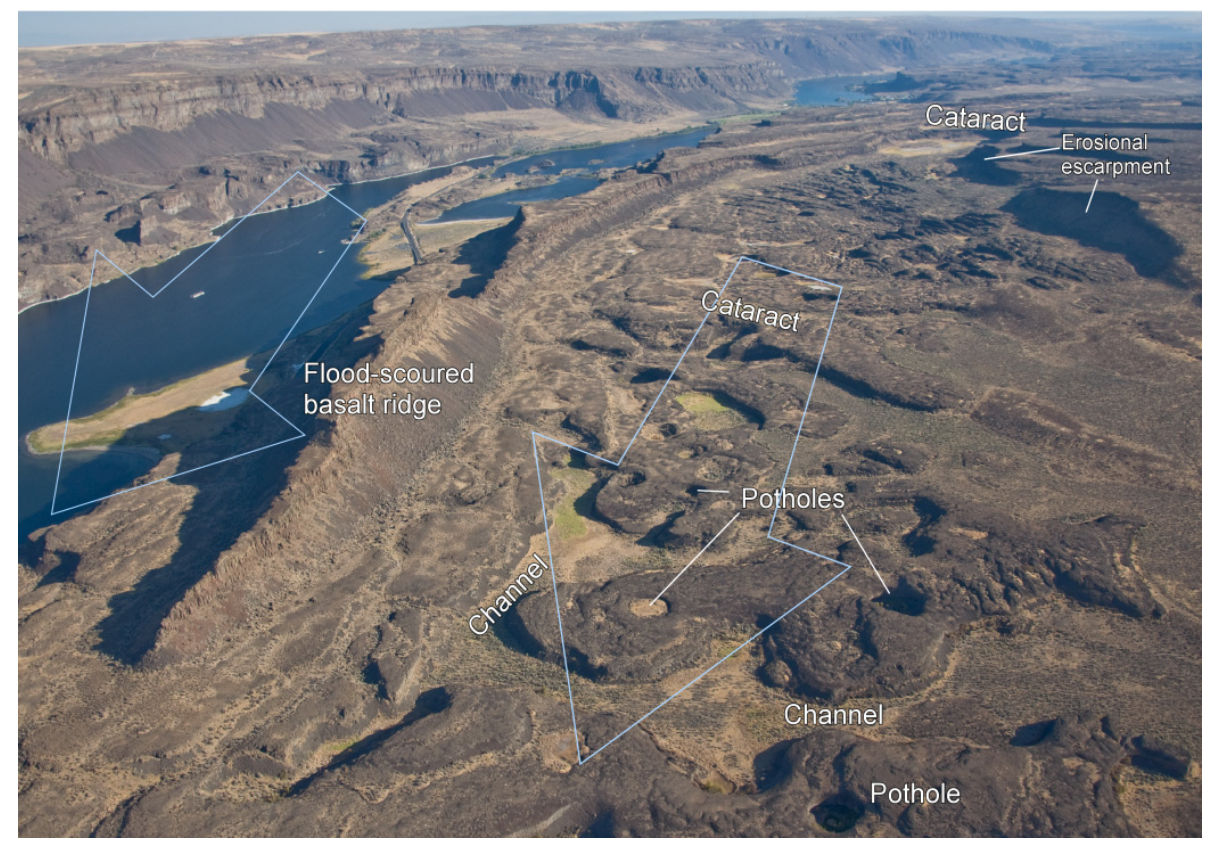

Figure 6.4. Example of highly irregular topography eroded by Ice Age floods, Lower Grand Coulee, Channeled Scabland. View looking north. Blue block arrows show general movement of floodwaters, which scoured and overtopped the crest of the basalt ridge along left side of image. Notice the numerous circular potholes in basalt bedrock, plucked out by violently swirling and turbulent floodwaters.

Paleochannel A was carved by floodwaters flowing east through the Pasco Basin. Upon colliding with Gable Mountain, the floodwaters divided (as shown in Figure 5.2) with some of the floodwater diverted north of Gable Mountain (Paleochannel B) and the remainder flowing south through Gable Gap via Paleochannels D, E, and F. Paleochannel C formed from Ice Age floodwaters that flowed east between Gable Butte and Cold Creek Bar (see Figure 3.3).

Paleochannel D, identified by Ault (1981) using a combination of geophysical techniques (i.e., gravity, magnetics, and seismic reflection), formed when floodwaters from Paleochannel A divided, sending vigorous streams of floodwater south through Gable Gap. Paleochannel D may have preferentially developed here along the structural axis of a buried syncline (see Figure 5.1). Just to the east, Paleochannel E appears to have incised into an anticline in basalt subparallel to Paleochannel D. This paleochannel is poorly defined via borehole data but suggested based on the seismic-reflection data (see Figure 2.5). At the southeast end of Paleochannel E lies a large pothole eroded into the Elephant Mountain Member basalt (defined by wells 699-48-48, 699-48-50, and 699-47-50) near the northeast corner of the 200 East Area (Figures 6.3 and D.1). 


\subsection{Hydrology}

The hydrologic system of Gable Gap includes the 1) vadose zone, mostly composed of the Hanford formation; 2) the suprabasalt unconfined aquifer; and 3) multiple confined aquifers within and between flows of volcanic Columbia River basalt. Within the vadose zone, movement of moisture and liquid effluent from the 200 East Area is strongly influenced by anisotropic sedimentary layering within the Hanford formation and the underlying Cold Creek unit (Serne et al. 2010). This includes a sizable, elongated, and streamlined mound of $\mathrm{CCUz}$, up to $55 \mathrm{ft}(17 \mathrm{~m})$ thick, $1 / 2$ mile $(0.8 \mathrm{~km})$ wide, and up to $2 \mathrm{mi}(3.2 \mathrm{~km})$ long that extends northwestward into Gable Gap from the northern 200 East Area (see Figures 4.7, B.5, and C.6). Additional anisotropic features exist in the layered flood deposits of the Hanford formation, which drape across the Cold Creek flood bar (see Figures 1.1 and 3.3). Hanford formation strata appear to dip north and east off the north side of the bar into Gable Gap-the expected direction for lateral movement of moisture and effluents within the vadose zone (Serne et al. 2010).

A large window occurs in central Gable Gap where the uppermost Saddle Mountains Basalt members (Elephant Mountain, Pomona, Asotin, and Esquatzel Members) were locally eroded away by the ancestral Columbia River as well as cataclysmic megafloods (Figure 7.1). This is an area for potential comingling of groundwater from unconfined and confined aquifers. The potential for aquifer intercommunication within this erosional window has long been recognized (Strait and Moore 1982; Graham et al. 1984; Jensen 1987; Spane and Webber 1995). However, vertical head differences measured between the confined and unconfined aquifers suggests that any local groundwater contamination will not travel far within interbeds of the Ellensburg Formation. While groundwater may be locally driven into the upperbasalt confined aquifer system due to previous water-table mounding conditions within the Gable Gap area, this groundwater will likely discharge back into the overlying unconfined aquifer due to the reversal in vertical hydraulic head conditions (Graham et al. 1984; Jensen 1987; Spane and Webber 1995).

Figure 7.2 shows the elevation of the water table in the study area; also shown is the stratigraphic unit in contact with the top of the unconfined aquifer. Groundwater, following the regional gradient, enters the study area from the west. The steep gradient just east of the 200 West Area is the result of groundwater flow being restricted to the lower-hydraulic-conductivity Ringold Formation sediments. However, the hydraulic gradient flattens rapidly to the east where the Ringold Formation is eroded below the water table. Here, the unconfined aquifer lies mostly within higher hydraulic conductivity sediments of the Cold Creek unit and Hanford formation. The flow of groundwater appears to divide in the 200 East Area, with some of the flow going north through Gable Gap and the remainder continuing east to southeast through the central and southern portions of the 200 East Area (beyond the southern boundary of Figure 7.2). Because of the extremely low hydraulic gradient conditions in this area, the exact location of the groundwater divide is difficult to delineate; however, based on currently available data, the general divide appears to lie near the northwest corner of the 200 East Area.

As mentioned, the extremely flat gradient in the vicinity of Gable Gap is a reflection of the relatively high hydraulic conductivity for the Hanford formation and Cold Creek unit gravel-dominated facies in this area. In general, the Hanford formation has a hydraulic conductivity that is frequently an order of magnitude (or more) greater than the Ringold Formation (Bjornstad 1990; Thorne et al. 2006). The Cold Creek unit gravel-dominated facies (CCUg) are of an intermediate hydraulic conductivity. Thus, the ability to transmit groundwater is greatest in the relatively young, coarse-grained Hanford formation, followed by the CCUg subunit, in contrast with the low-K Ringold and Ellensburg Formations. 


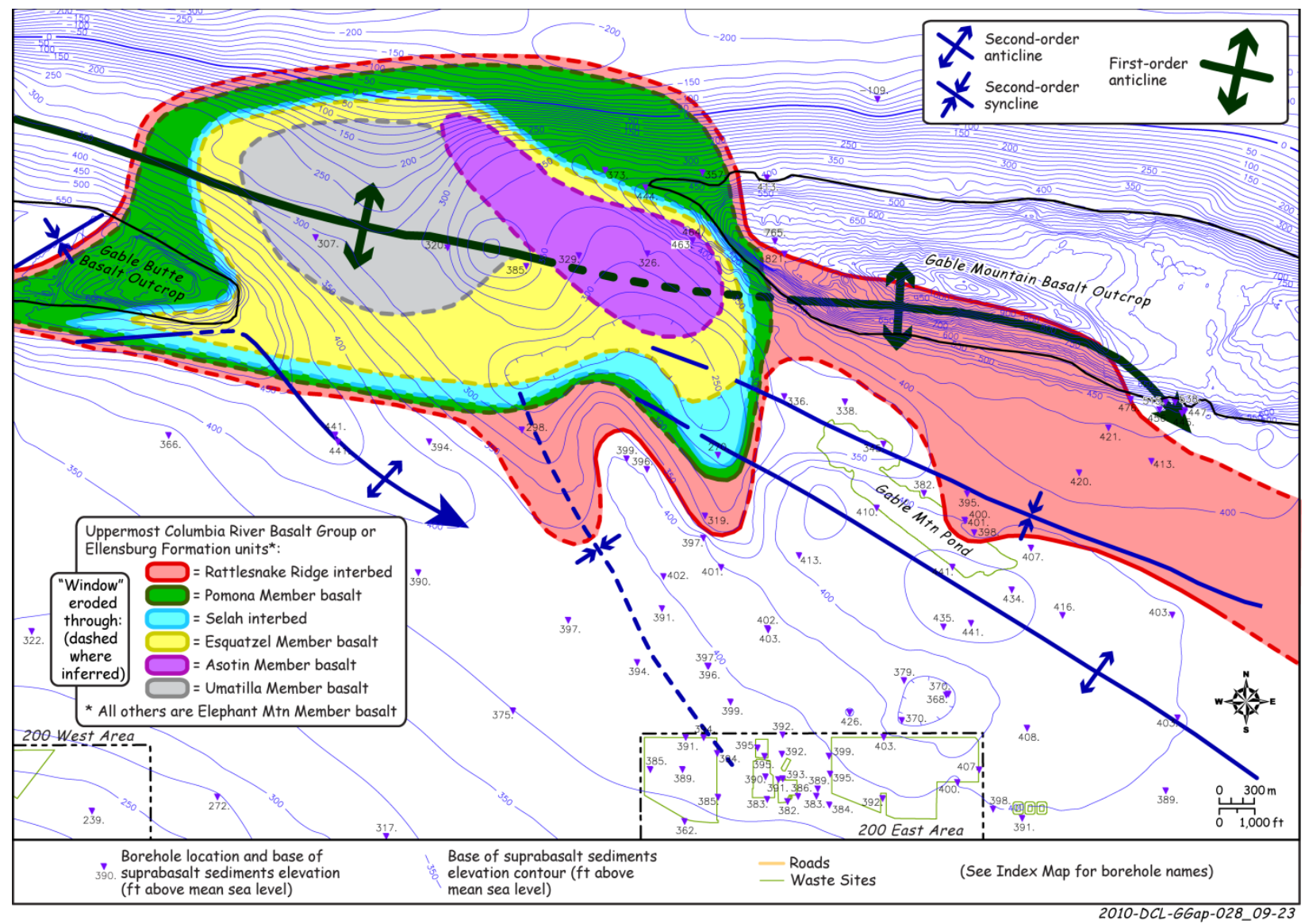

Figure 7.1. Location of window eroded through the upper flows of Columbia River Basalt Group within Gable Gap 


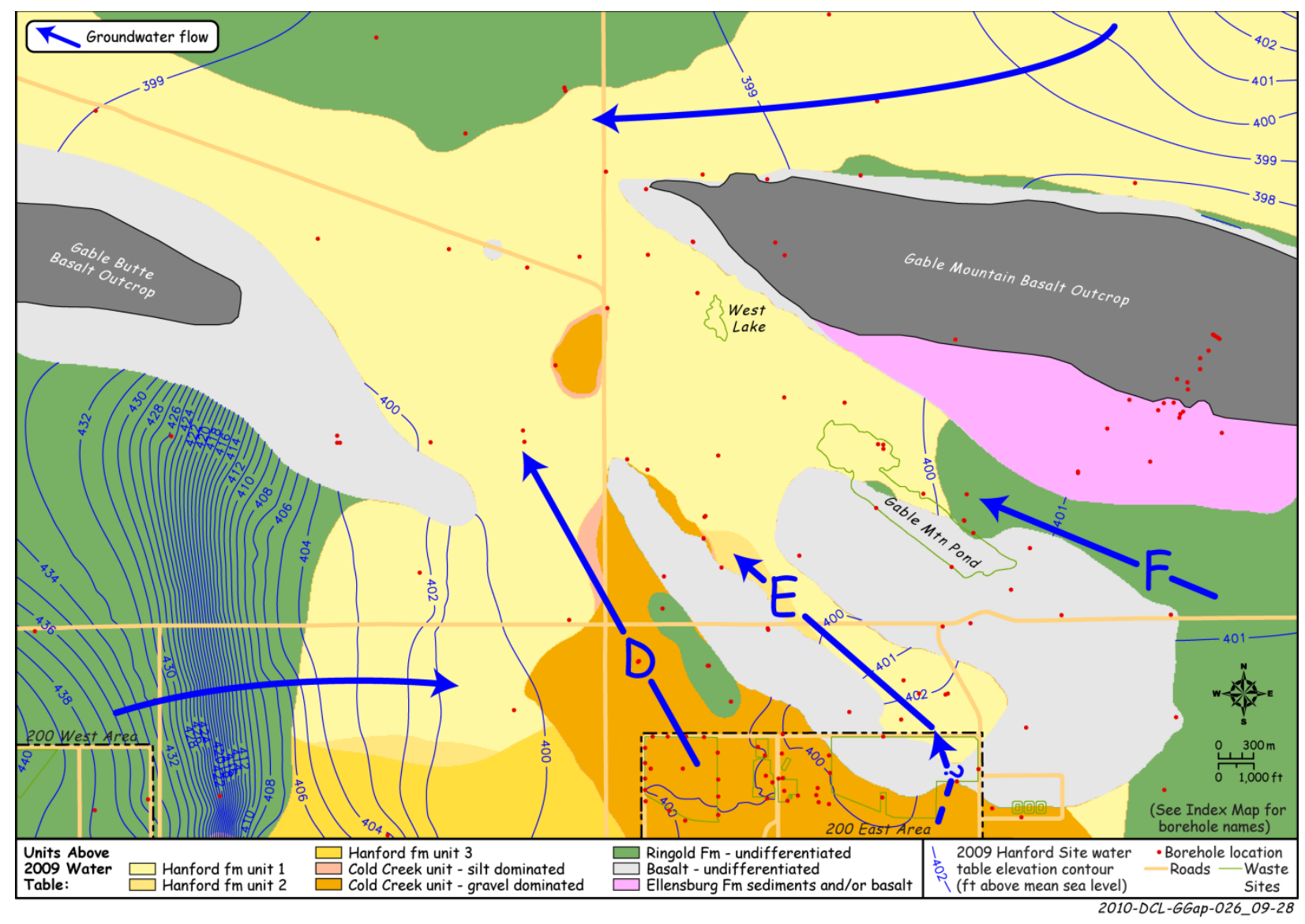

Figure 7.2. Distribution of stratigraphic units encountered at the 2009 water table. Arrows indicate flow of groundwater in the unconfined aquifer under the present flow regime. Flow occurs along buried Paleochannels D, E, and F shown in Figure 6.3.

The thickness of the unconfined aquifer is highly variable across Gable Gap (Figure 7.3). This is due to the irregular, tectonically deformed and eroded surface at the top of basalt (see Figure 2.5). The unconfined aquifer is relatively thick in the northwestern portion of the study area where erosion was most extreme. However, the amount of erosion decreases to the south and therefore so does the aquifer thickness. The thickness of unconfined aquifer thins to only a few feet or less, including the less-eroded high points along Paleochannels D, E, and F (Figure 6.3) discussed previously in Section 6.2. Because of a limited number of wells in the area of question, considerable uncertainty exists on the configuration of the paleochannels and top of basalt. Thus, there could be areas across the basalt divide that are incised deeper into the basalt, resulting in a localized conduits for the preferential flow of groundwater. 


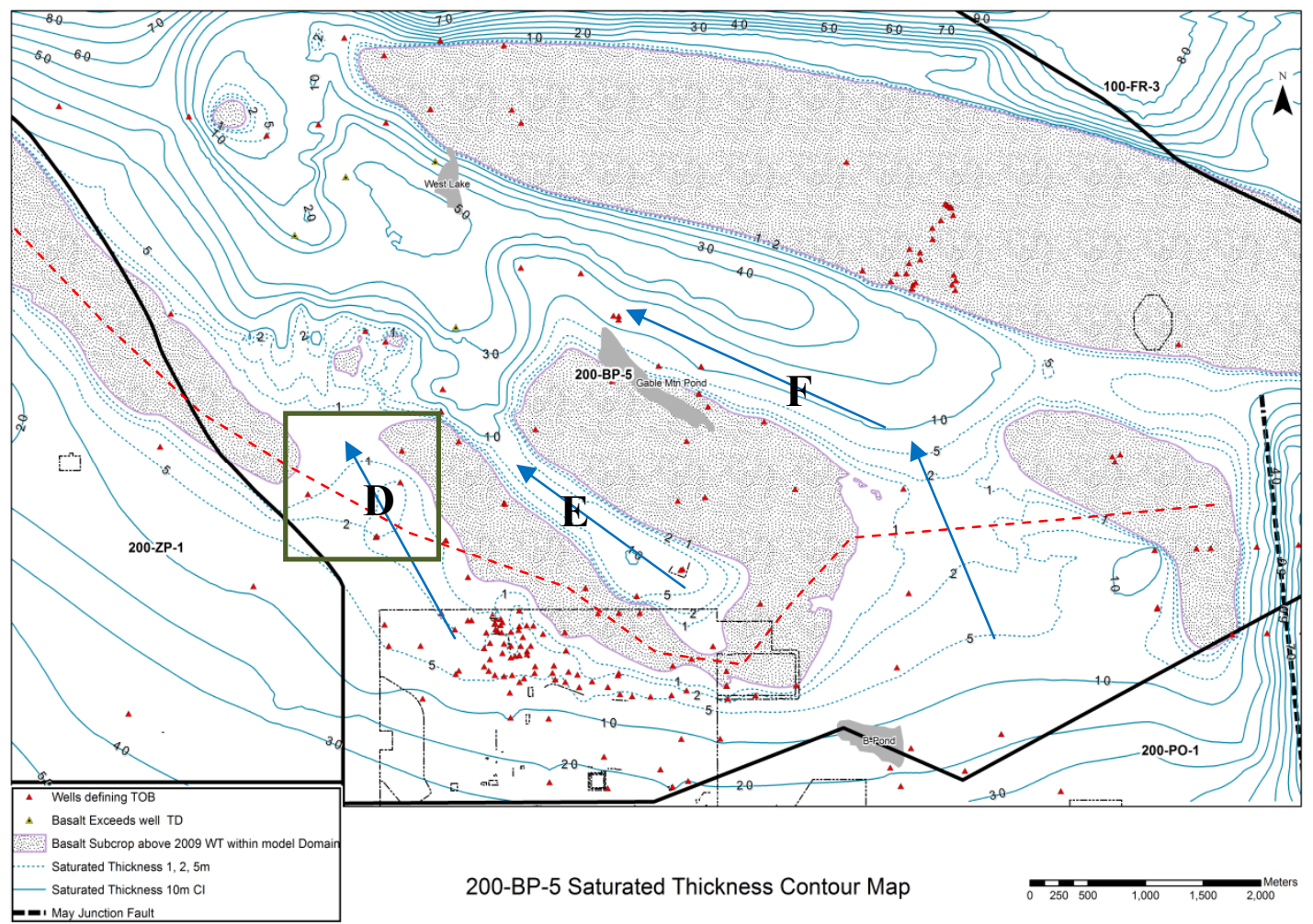

Figure 7.3. Aquifer thickness (in meters) map in the vicinity of Gable Gap. Thickness is based on the difference between the 2009 site-wide groundwater table and estimated top of basalt map shown in Figure 2.5. Blue arrows show possible groundwater flow paths across Gable Gap along buried paleochannels. Dashed red line marks the high basalt divide that separates the Wahluke and Cold Creek synclinal structural basins. Green rectangle marks critical area of uncertainty for the future of contaminated groundwater moving through Gable Gap.

Note that the thickness of the unconfined aquifer, represented in Figure 7.3, includes all strata down to the top of basalt, which includes the uppermost sedimentary interbed of the Ellensburg Formation in the area of the erosional window shown in Figure 7.1. Because of its impermeable, fine-grained, and semi-lithified nature, the Ellensburg Formation may behave more like an aquitard than an aquifer. If so, then the true unconfined aquifer thickness would be something less than that represented in Figure 7.3 in the area of the erosional window.

Groundwater appears to flow northward through Gable Gap via one or more paleochannels eroded into basalt (Figure 7.3). At least three paleochannels (D, E, and F) transect Gable Gap (see Figure 6.3). In some places, these channels are many tens of feet deep (e.g., see hydrogeologic cross sections B-B' and $\mathrm{C}-\mathrm{C}$ ' in Appendix A). Elsewhere, along the lengths of the paleochannels, the top of basalt rises toward the water table. Significant thinning of the aquifer along these paleochannels occurs at the basalt divide well south of Gable Gap (red dashed line in Figure 7.3). The thinning of the unconfined aquifer near this divide is apparent along the west side of the hydrogeologic cross section D-D' (Figure A.5).

Among the paleochannels that transect Gable Gap, Paleochannel E is interpreted here to be completely cut off from the flow of groundwater under the present hydrologic regime, although some investigators believe the northern of two Tc-99 plumes in Figure 2.5 is evidence for contaminated 
groundwater flowing through this paleochannel. However, Paleochannel D definitely appears to be transferring groundwater across Gable Gap to the northwest. This is based on historical contaminant flow associated with tritium, and more recently with detection of Tc-99 and I-129 (DOE/RL 2010). The southern of two Tc-99 plumes (Figure 2.5) is believed coincident with Paleochannel D.

Groundwater may also be moving northwestward through Gable Gap along Paleochannel F as well. However, the rate of groundwater flow may be significantly reduced in comparison to Paleochannel D considering the flow of groundwater is through low-K Ringold Formation sediments. Furthermore, if groundwater flows through Paleochannel F it does not appear to be impacted by any Hanford wastemanagement activities.

Groundwater levels in Gable Gap wells have fluctuated considerably since artificial recharge at the Hanford Site began around 1944 (Figure 7.4). These reflect changes in discharges to ground in the vicinity of the 200 East Area (Figure 7.5). Groundwater levels increased dramatically and steadily from 1954 to 1963, reaching a maximum between 1968-1969. This spike in water levels was the result of groundwater mounding associated with discharges to Gable Mountain pond. Maximum water levels were followed by a temporary low between 1978-1979 when artificial recharge was significantly reduced (Serne et al. 2010). Another rise in the water table occurred in 1986-1987 associated with increased discharge to the B Pond system, just east of the 200 East Area (see Figure 7.3 for location). Hanford Site well-water levels have been steadily declining since 1990, when wastewater discharges to the ground were terminated. Water levels have dropped an average rate of $\sim 0.5 \mathrm{ft} / \mathrm{y}(0.14 \mathrm{~m} / \mathrm{y})$ in the northern portion of the 200 East Area since the cessation of these disposal practices (Horton 2007). The rate of decline can be expected to diminish as the water table continues to drop to pre-Hanford levels. As the water table approaches pre-Hanford levels, groundwater flow northwestward through Gable Gap may be more restricted to the incised portion of Paleochannel D. Eventually, the flow of groundwater may be diverted away from Gable Gap altogether if water levels continue to decline across the basalt divide within Gable Gap. However, because of a limited number of wells in the area of question, considerable uncertainty exists on the configuration of the Paleochannel D and the top of basalt (represented by a green rectangle in Figure 7.3). Therefore, the possibility exists there could be localized areas along the basalt divide that are incised deeper and therefore might transport groundwater indefinitely. Significant relief is known to exist in other eroded areas exposed by cataclysmic Ice Age floods (e.g., see Figure 6.4).

As groundwater levels continue to decline in the region, most groundwater flow may eventually be diverted from flowing through Gable Gap. However, localized flow may continue indefinitely in the vicinity of Paleochannel D if there are any as-yet undetected, locally deeper channels across the basalt divide shown in Figure 7.3. 


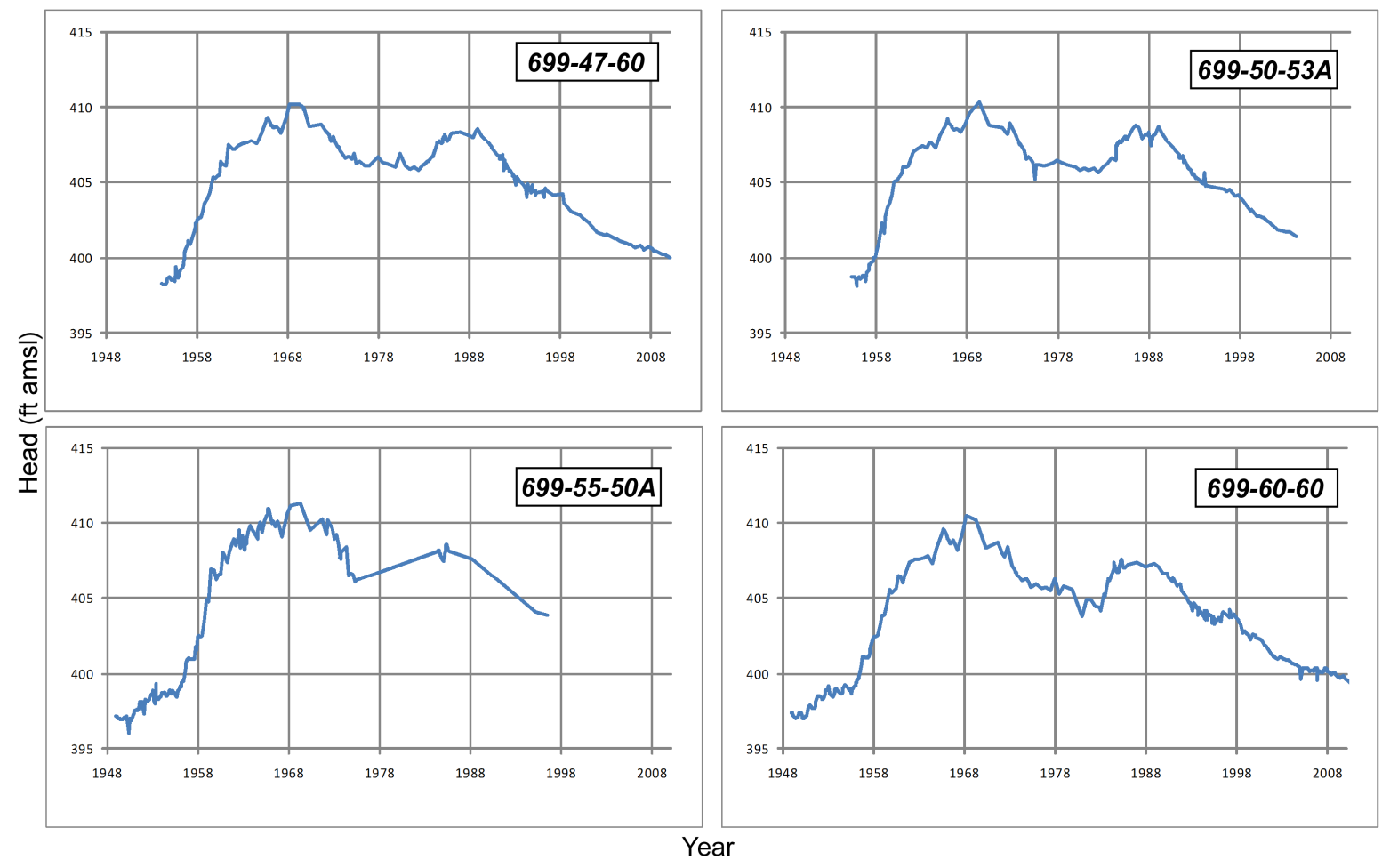

Figure 7.4. Selected hydrographs of Gable Gap wells open to the unconfined aquifer (Hanford formation). Present water levels appear to be a few feet $(1 \mathrm{~m})$ above pre-Hanford Site (1944) conditions, after once being almost $15 \mathrm{ft}(4.6 \mathrm{~m})$ above the pre-Hanford Site water level.

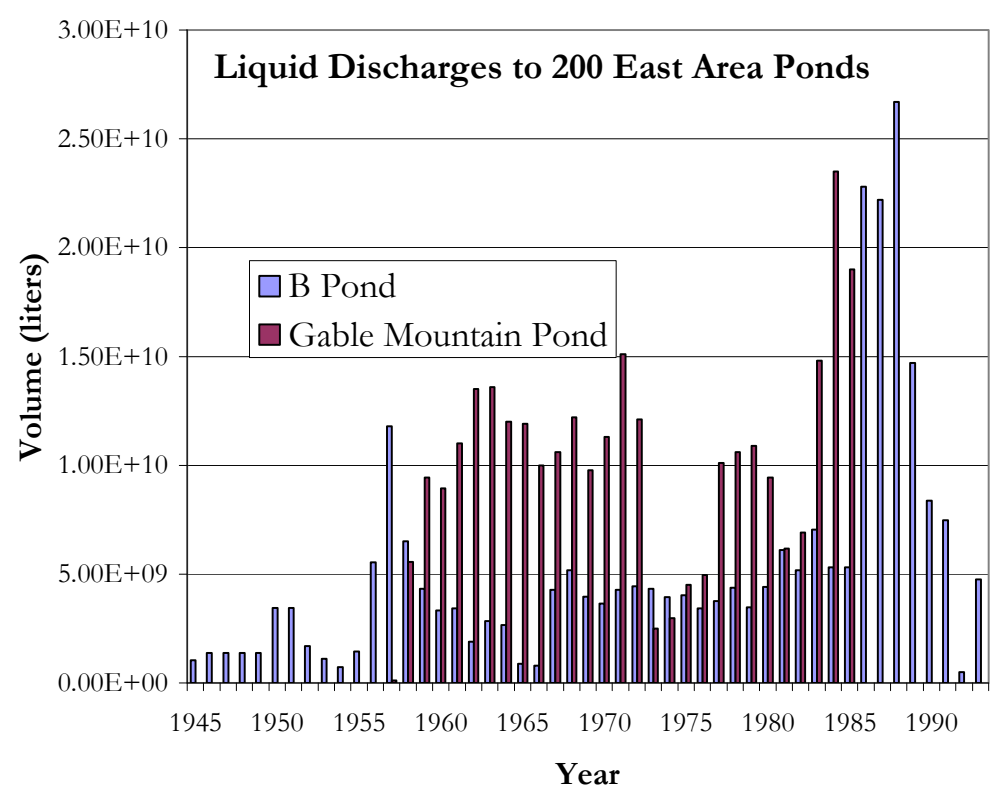

Figure 7.5. Discharge history for the B Pond and the Gable Mountain Pond systems. Source: Horton (2008). 


\subsection{Conclusions}

Gable Gap has a complex geologic history based on the long record of tectonism, erosion, and deposition located in an ancient water gap of the Columbia River. The following provides a synopsis of Gable Gap's geologic history.

Gable Gap's origins go back to the Miocene Epoch when lava flows of Columbia River basalt blanketed the area. Simultaneous with emplacement of the lava flows was north-south tectonic compression, which resulted in the growth of the YFB including the Umtanum Ridge-Gable Mountain anticline. This central anticline bisects the Pasco Basin and includes the second-order, en echelon folds of Gable Mountain and Gable Butte, which slowly uplifted between lava eruptions. This is indicated by the thickness of the lava flows and sedimentary interbeds of the Ellensburg Formation, which thin over the anticlinal ridges. More and more time separated basalt eruptions, so that towards the end of Columbia River basalt time, hundreds of thousands to millions of years separated basalt flows until the last flow covered the gap about 10.5 million years ago. Following basalt volcanism, the Umtanum Ridge-Gable Mountain uplift continued its long-term average slow growth.

The ancestral Columbia River continued to slowly fill the subsiding synclinal basins north and south of Gable Mountain/Gable Butte with sediments of the Ringold Formation (Fecht et al. 1987; DOE 1988; Lindsey 1995). During much of the Ringold time period, the Columbia River maintained a channel southeastward through the central Pasco Basin including Gable Gap (Fecht et al. 1987; Lindsey 1996). Aggradation of the Ringold Formation continued for another 7 million years, slowly filling in the Pasco Basin with fluvial and lacustrine sediments. During some of the Ringold time period, it appears the antecedent Columbia River may have flowed over bedrock to expose the Columbia River basalt across the axis of the Umtanum Ridge-Gable Mountain anticline within Gable Gap. Several of the upper basalt layers, along with intercalated sedimentary interbeds of the Ellensburg Formation, were locally removed along the crest of the tightly folded and fractured anticline during this time (Figure 8.1, Stage A). Infilling of the ancestral Columbia River channels with Ringold-age deposits suggest the earliest channels developed during the Ringold time interval.

Suddenly (with respect to geologic time) about 3 million years ago, infilling of the synclinal basins ceased and the Columbia River began to erode and incise back down into the Ringold Formation, removing much of the sediment previously deposited from the center of the basin. (The area known as White Bluffs is an erosional remnant of the former Ringold surface.) The cause for the incision is believed to be the result of regional tectonic uplift and Cascade volcanism associated with the ancestral Cascade Range, or perhaps the downstream breaching of a volcanic dam in the Columbia River Gorge (Fecht et al. 1987). Within a relatively short time, the Columbia River found a new base level that was $\sim 500 \mathrm{ft}(150 \mathrm{~m})$ lower than at the end of the Ringold time period.

The ancestral post-Ringold Columbia River continued to flow through Gable Gap into early Cold Creek time (Figure 8.1, Stage A). Along the new channel, the Columbia River partially backfilled low areas with additional fluvial-channel deposits, creating the Cold Creek unit. A train of Cold Creek gravels spreads out southeast of Gable Gap, marking the former path of the Columbia River through the central Hanford Site. The transition from gravel-dominated to silt-dominated sediments of the Cold Creek unit marks the shift of the ancestral Columbia River out of Gable Gap and into the Wahluke syncline north of Gable Mountain (Figure 8.1, Stage B). The cause for this dramatic, permanent shift in the river channel 
may have been due to tectonic uplift along the Umtanum Ridge-Gable Mountain structure. With the river channel out of the gap, fluvial overbank deposits (CCUz) would have begun to accumulate within the abandoned Gable Gap.
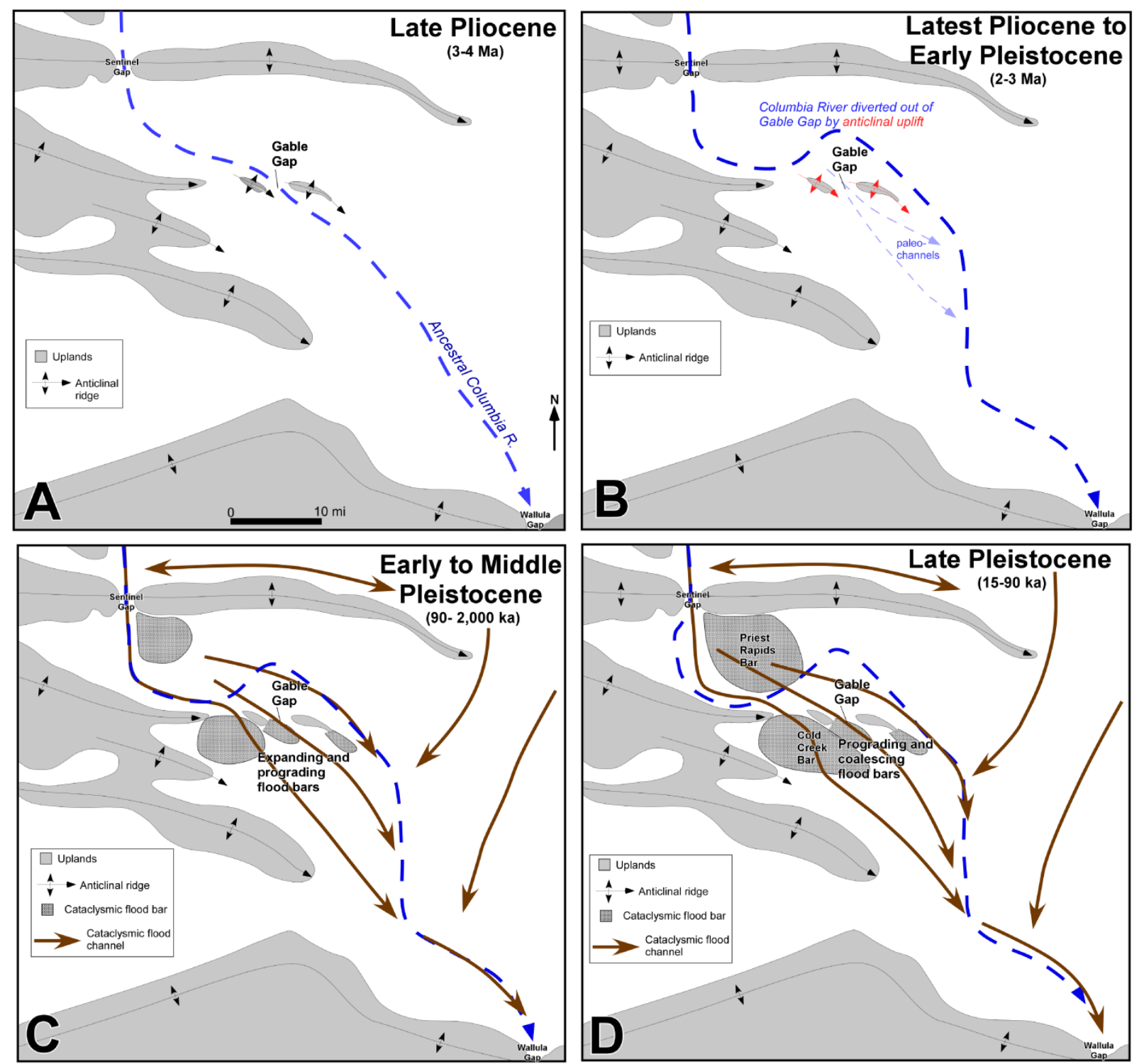

gg.chron.comp.jpg

Figure 8.1. Late-Cenozoic history and evolution of paleodrainage in the vicinity of Gable Gap

During the Ice Age (Pleistocene Epoch), massive cataclysmic floods repeatedly occurred. Erosion and deposition by Ice Age floods had a profound effect on the Pasco Basin and overwhelmed all other geologic processes occurring during or since the Pleistocene. The exact age of the earliest Ice Age floods to pass through the Pasco Basin is unknown. The oldest documented floods were at least 780,000 years ago (Bjornstad et al. 2001; Pluhar et al. 2006), although the first floods may have occurred closer to the beginning of the Ice Age around 2.6 million years ago. Evidence for the earliest floods has since either been eroded away by a hundred or more younger floods, or lies buried beneath the cover of younger flood 
deposits. The Ice Age was not a single climatic event-instead, glacial periods were cyclic, occurring about every 100,000 years over at least the last million years (Figure 8.2). Ice Age floods may be associated with each major glacial advance. In between glacial cycles were several tens of thousands of years of interglacial conditions similar to those of today. It is possible the earliest cycles going back to the beginning of the Pleistocene Epoch were not as regular or well behaved as the last cycles shown in Figure 8.2.

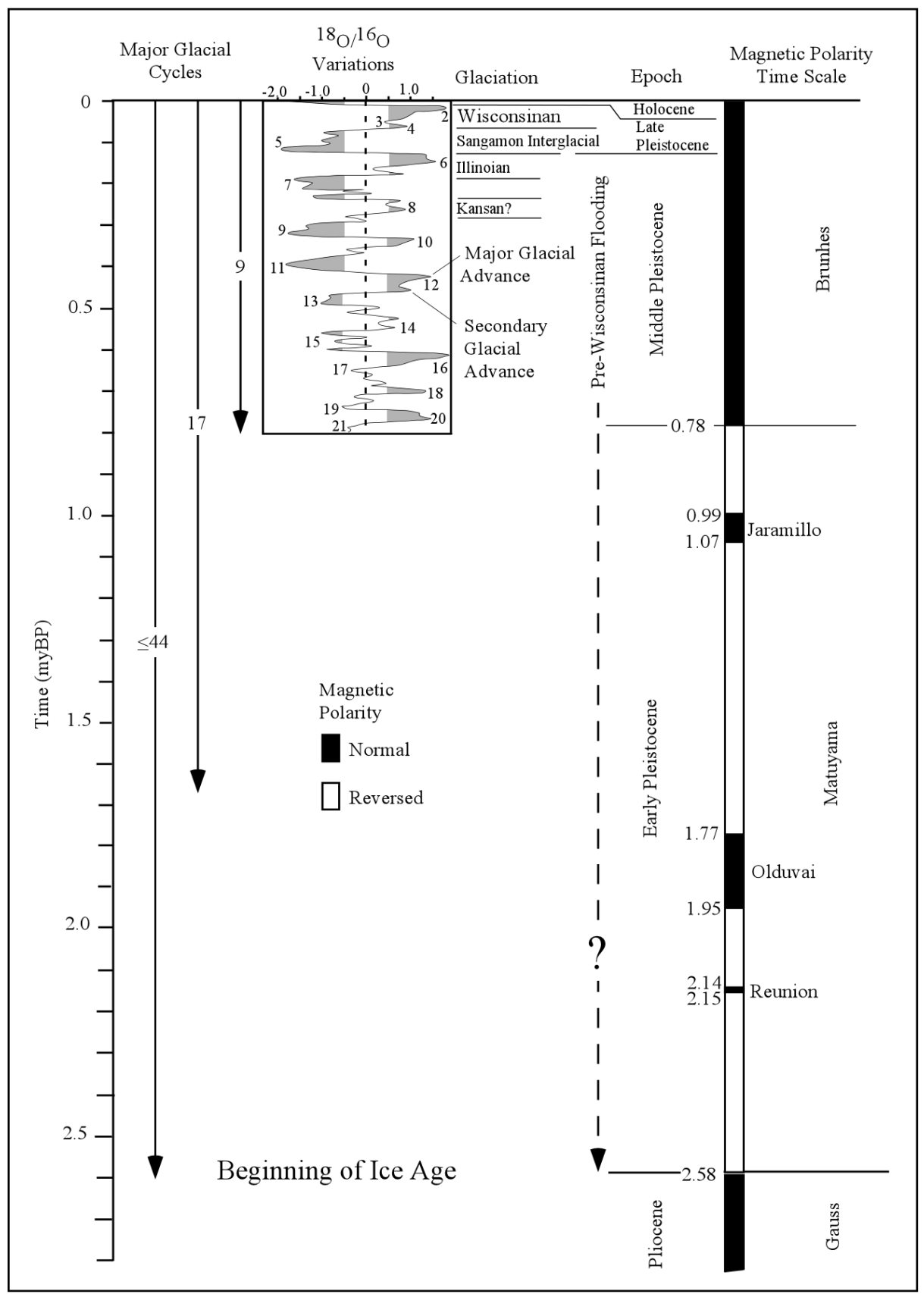

Figure 8.2. Ice Age floods in geologic time. The Ice Age, equivalent to the Pleistocene Epoch, lasted from 2.6 million years ago until about 15,000 years ago. Source: Bjornstad (2006). 
Intense erosion occurred with the earliest Ice Age floods as they squeezed through the narrowed hydraulic constriction at Gable Gap. Locally, the floods scoured out deep rock basins and potholes in the uppermost basalt flows and interbeds (e.g., wells 6-55-60 and 6-55-55 in cross section C-C'

[Figure A.4]). This resulted in the local removal of all pre-existing suprabasalt sediments along the narrowest section of the gap. In the south part of Gable Gap, the floods shaped a cohesive, flood-resistant sequence of CCUz into an elongated mound, reminiscent of those eroded by Missoula floods within the Channeled Scabland (see Figure 4.8). The streamlined island, capped with a thick cover of cohesive silt, effectively protected an underlying Cold Creek unit gravel sequence and Ringold Formation sediments from flood erosion at the core of the islands (see Figures 2.2, 4.7, A.2, and A.5). Seismic-reflection data also support the presence of remnant, pre-Hanford-formation mounds in the subsurface (Repasky et al. 2009).

Several huge flood bars, including the Cold Creek, Priest Rapids, and Gable Mountain bars, probably began developing with the first floods early in the Pleistocene age (see Figure 8.1, Stage C). Erosional flood channels and streamlined islands capped with CCUz in Gable Gap were eventually buried as each flood deposited more sediment and the flood bars expanded and prograded east from Umtanum Ridge (see Figure 3.3). Eventually the bars expanded across Gable Gap, covering the older flood channels and streamlined hills with younger flood-bar deposits (Figure 8.1, Stage D). Even though the Columbia River had permanently shifted north, subsequent Ice Age floods continued to periodically flow through Gable Gap, reworking and carving shallow channels into the flood deposits. The configuration of the flood bars and channels from the last Ice Age flood about 15,000 years ago is as it appears today (see Figure 6.2). Since the end of the Ice Age, only minor changes to Gable Gap have been those caused by localized wind deposition or by humans.

Today, basalt extends above the water table and groundwater from the Central Plateau moves through Gable Gap within one or more paleochannels eroded into the basalt (Figure 8.3). If groundwater levels continue to decline, groundwater flow to the northwest of the 200 East Area through Gable Gap may become more restricted or cut off as water levels drop across the buried basalt divide. However, other asyet unidentified deeper channels across the basalt divide may allow for flow of groundwater to continue indefinitely. 


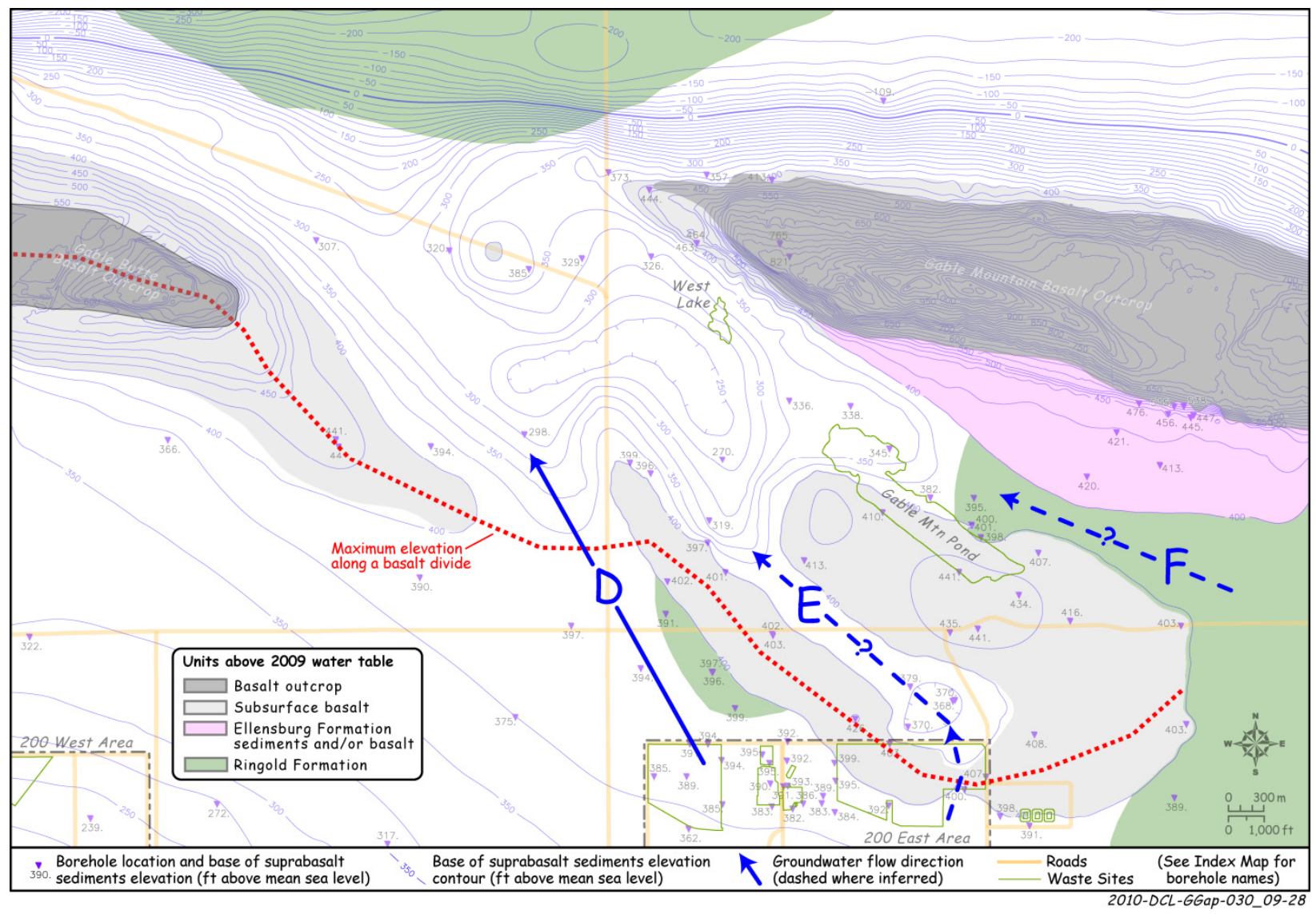

Figure 8.3. Areas of suspected groundwater flow through Gable Gap from the Central Plateau. Flow appears to be occurring along deeply buried paleochannels within the Gap (Paleochannels D, $\mathrm{E}$, and $\mathrm{F}$ in Figure 6.3). Flow continues via a Paleochannel D from the northwest corner of the 200 East Area. Flow through Paleochannels E and F may also be moving through Gable Gap. Red dotted line marks maximum elevation along a basalt divide. 


\subsection{References}

Ault TD. 1981. "Appendix D - Geophysical Investigations of the Gable Mountain-Gable Butte Area." Appendix in Subsurface Geology of the Cold Creek Syncline Area, eds CW Myers and SM Price. RHO-BWI-ST-14, Rockwell Hanford Operations, Richland, Washington, pp. D-1 to D-24.

Baker VR. 1978. "Large-scale Erosional and Depositional Features of the Channeled Scabland." Chapter in The Channeled Scabland, eds VR Baker and D Nummedal. National Aeronautics and Space Administration, Washington D.C., pp. 186.

Baker VR and RC Bunker. 1985. "Cataclysmic Late Pleistocene Flooding from Glacial Lake Missoula: A Review." Quaternary Science Reviews 4:1-41.

Baker VR, BN Bjornstad, AJ Busacca, KR Fecht, EP Kiver, UL Moody, JG Rigby, DF Stradling, and AM Tallman. 1991. "Quaternary Geology of the Columbia Plateau." Chapter in Quaternary Nonglacial Geology: Conterminous U.S./With Plates (Geology of North America), ed. RB Morrison. Series: The Geology of North America; v. K-2. Geological Society of America, Boulder, Colorado.

Bjornstad BN. 1980. "Sedimentology and Depositional Environment of the Touchet Beds, Walla Walla River Basin, Washington.” Eastern Washington University Master's Thesis, Cheney, Washington, 83 p.

Bjornstad BN. 1990. Geohydrology of the 218-W-5 Burial Ground, 200-West Area, Hanford Site. PNL-7336, Pacific Northwest Laboratory, Richland, Washington.

Bjornstad BN. 2006. On the Trail of the Ice-Age Floods: A Geological Field Guide to the MidColumbia Basin. Keokee Company Publishing, Inc., Sandpoint, Idaho, pp. 307.

Bjornstad, BN, KR Fecht, and CJ Pluhar. 2001. "Long History of Pre-Wisconsin, Ice Age Cataclysmic Floods: Evidence from Southeastern Washington State." Journal of Geology 109:695-713.

Black RF. 1979. Clastic Dikes of the Pasco Basin, Southeastern Washington. RHO-BWI-C-64, Rockwell Hanford Operations, Richland, Washington.

Brown, CF, RE Clayton, JP Icenhower, W Um, BN Bjornstad et al. 2007. Characterization of DirectPush Vadose Zone Sediments from the 241-B and 241-BX Tank Farms. PNNL-17162, Pacific Northwest National Laboratory, Richland, Washington.

DOE. 1988. Site Characterization Plan: Reference Repository Location, Hanford Site, Washington. DOE/RW-0164, Vol. 1, U.S. Department of Energy, Washington, D.C.

DOE/RL. 2002. Standardized Stratigraphic Nomenclature for the Post-Ringold-Formation Sediments Within the Central Pasco Basin. DOE/RL-2002-39, Rev. 0, U.S. Department of Energy, Richland Operations Office, Richland, Washington.

DOE/RL. 2010. Hanford Site Groundwater Monitoring and Performance Report for 2009. DOE/RL2010-11, Rev. 1, U.S. Department of Energy, Richland Operations Office, Richland, Washington. 
Fecht KR. 1978. Geology of Gable Mountain-Gable Butte Area. RHO-BWI-LD-5, Rockwell Hanford Operations, Richland, Washington.

Fecht KR, SP Reidel, and AM Tallman. 1987. "Paleodrainage of the Columbia River System on the Columbia Plateau of Washington State - A Summary." Chapter in Selected Papers on the Geology of Washington, JE Schuster, ed., Washington Division of Geology and Earth Resources, Bulletin 77, pp. 219-248.

Fecht KR and DC Weekes. 1996. Geologic Field Inspection of the Sedimentary Sequence at the Environmental Restoration Disposal Facility. BHI-00230, Bechtel Hanford, Inc., Richland, Washington.

Fecht KR, BN Bjornstad, DG Horton, GV Last, SP Reidel, and KA Lindsey. 1999. Clastic Injection Dikes of the Pasco Basin and Vicinity: Geologic Atlas Series. BHI-01103, Rev. 0, Bechtel Hanford, Inc., Richland, Washington.

Graham MJ, GV Last, and KR Fecht. 1984. An Assessment of Aquifer Intercommunication in the B Pond-Gable Mountain Pond Area of the Hanford Site. RHO-RE-ST-12P, Rockwell Hanford Operations, Richland, Washington.

Hoffman KM, SJ Trent, KA Lindsey, and BN Bjornstad. 1992. Summary of the Geology of the 200-BP-1 Operable Unit. WHC-SD-EN-TI-037, Westinghouse Hanford Company, Richland, Washington.

Holmes GE and TH Mitchell. 1981. "Appendix B-Seismic-Reflection and Multilevel Aeromagnetic Surveys in the Cold Creek Syncline Area." Chapter in Subsurface Geology of the Cold Creek Syncline Area, eds CW Myers and SM Price. RHO-BWI-ST-14, Rockwell Hanford Operations, Richland, Washington, pp. B-1 to B-56.

Horton DG. 2007. Data Package for Past and Current Groundwater Flow and Contamination Beneath Single-Shell Tank Waste Management Areas. PNNL-15837, Pacific Northwest National Laboratory, Richland, Washington.

Horton DG. 2008. "Appendix H: Past and Current Groundwater Flow and Contamination Beneath Shell Tank Waste Management Areas.” (Published in 2007 as PNNL-15837). In The Resource Conservation and Recovery Act Facility Investigation (RFI) Report for Hanford Single-Shell Tank Waste Management Areas, DOE/ORP-2008-01, Rev. 0, Vol. Tier 2, ed. FM Mann. U.S. Department of Energy, Office of River Protection, Richland, Washington.

Jensen EJ. 1987. An Evaluation of Aquifer Intercommunication Between the Unconfined and Rattlesnake Ridge Aquifers on the Hanford Site. PNL-6313, Pacific Northwest Laboratory, Richland, Washington.

Last GV, BN Bjornstad, MP Bergeron, DW Wallace, DR Newcomer, JA Schramke, MA Chamness, CS Cline, SP Airhart, JS Wilbur. 1989. Hydrogeology of the 200 Areas Low-Level Burial Grounds - An Interim Report. PNL-6820, 2 volumes, Pacific Northwest Laboratory, Richland, Washington.

Lindenmeier CW, RJ Serne, BN Bjornstad, GV Last, DC Lanigan, MJ Lindberg, RE Clayton, VL Legore, IV Kutnyakov, SR Baum, KN Geiszler, MM Valenta, and TS Vickerman. 2002. Characterization of Vadose Zone Sediment: Borehole C3103 Located in the 216-B-7A Crib Near the B Tank Farm. PNNL-14128, Pacific Northwest National Laboratory, Richland, Washington. 
Lindenmeier CW, RJ Serne, BN Bjornstad, GW Gee, HT Schaef, DC Lanigan, MJ Lindberg, RE Clayton, VL Legore, IV Kutnyakov, SR Baum, KN Geiszler, CF Brown, MM Valenta, TS Vickerman, and LJ Royack. 2003. Characterization of Vadose Zone Sediment: RCRA Borehole 299-E33-338 Located Near the B-BX-BY Waste Management Area. PNNL-14121, Rev. 1, Pacific Northwest National Laboratory, Richland, Washington.

Lindsey KA. 1995. "Miocene- to Pliocene-Aged Suprabasalt Sediments of the Hanford Site, SouthCentral Washington.” BHI-00184, Bechtel Hanford, Inc., Richland, Washington.

Lindsey KA. 1996. "The Miocene to Pliocene Ringold Formation and Associated Deposits of the Ancestral Columbia River System, South-Central Washington and North-Central Oregon." Open-File Report 96-8, Washington Division of Geology and Earth Resources, Department of Natural Resources, Olympia, Washington.

Lindsey KA, BN Bjornstad, J Lindberg, and KM Hoffman. 1992. Geologic Setting of the 200 East Area: An Update. WHC-SD-EN-TI-012, Rev. 0, Westinghouse Hanford Company, Richland, Washington.

Martin BH, HL Petcovic, and SP Reidel. 2005. Goldschmidt Conference 2005: Field Trip Guide to the Columbia River Basalt Group. PNNL-15221, Pacific Northwest National Laboratory, Richland, Washington.

McKee EH, DA Swanson, and TL Wright. 1977. Duration and Volume of Columbia River Basalt Volcanism: Washington, Oregon, and Idaho, Geological Society of America, Abstracts with Programs, Vol. 9, no. 4, p. 463-464.

Myers CW and SM Price, eds. 1979. Geologic Studies of the Columbia Plateau: A Status Report. RHO-BWI-ST-4, Rockwell Hanford Operations, Richland, Washington.

O'Connor JE. 1993. "Hydrology, Hydraulics, and Geomorphology of the Bonneville Flood." GSA Special Paper No. 274, Geological Society of America, Boulder, Colorado, pp. 83.

Petersen RE. 1992. Hydrologic and Geologic Data Available for the Region North of Gable Mountain, Hanford Site, Washington. WHC-SD-EN-TI-006, Westinghouse Hanford Company, Richland, Washington.

Pluhar CJ, BN Bjornstad, SP Reidel, RS Coe, and PB Nelson. 2006. "Magnetostratigraphic Evidence from the Cold Creek Bar for Onset of Ice-Age Cataclysmic Floods in Eastern Washington During the Early Pleistocene." Quaternary Research 65:123-135.

PSPL - Puget Sound Power and Light Company. 1982. Skagit/Hanford Nuclear Project, Preliminary Safety Analysis Report, v. 4, App. 20, Amendment 23. Puget Sound Power and Light Company, Bellevue, Washington.

Reidel SP. 1984. "The Saddle Mountains: The Evolution of an Anticline in the Yakima Fold Belt." American Journal of Science 284:942-978. 
Reidel SP and KR Fecht. 1981. "Wanapum and Saddle Mountains Basalts of the Cold Creek Syncline Area." Chapter in Subsurface Geology of the Cold Creek Syncline Area, eds CW Myers and SM Price. RHO-BWI-ST-14, Rockwell Hanford Operations, Richland, Washington.

Reidel SP and MA Chamness. 2007. Geology Data Package for the Single-Shell Tank Waste Management Areas at the Hanford Site. PNNL-15955, Pacific Northwest National Laboratory, Richland, Washington.

Repasky TR, ER Hyde, CA Link, and MA Speece. 2009. Landstreamer/Gimbaled Geophone Acquisition of High-Resolution Seismic Reflection Data North of the 200 Areas - Hanford Site. SGW-43746, Rev. 0, prepared for the U.S. Department of Energy by CH2M HILL Plateau Remediation Company, pp. 68.

Rhoads K, BN Bjornstad, RE Lewis, SS Teel, KJ Cantrell, RJ Serne, JL Smoot, CT Kincaid, and SK Wurstner. 1994. Estimation of the Release and Migration of Lead Through Soils and Groundwater at the Hanford Site 218-E-12B Burial Ground. PNL-8356, Vol. 1, Pacific Northwest Laboratory, Richland, Washington.

Serne RJ, GV Last, GW Gee, HT Schaef, DC Lanigan, CW Lindenmeier, MJ Lindberg, RE Clayton, VL Legore, RD Orr, IV Kutnyakov, SR Baum, KN Geiszler, CF Brown, MM Valenta, and TS Vickerman. 2002. Characterization of Vadose Zone Sediment: Borehole 299-E33-45 Near BX-102 in the B-BX-BY Waste Management Area. PNNL-14083, Pacific Northwest National Laboratory, Richland, Washington.

Serne RJ, BN Bjornstad, GW Gee, HT Schaef, DC Lanigan, RG McCain, CW Lindenmeier, RD Orr, VL LeGore, RE Clayton, MJ Lindberg, IV Kutnyakov, SR Baum, KN Geiszler, MM Valenta, TS Vickerman, LJ Royack. 2003. Characterization of Vadose Zone Sediment: Borehole 299-E33-46 Near B 110 in the B BX-BY Waste Management Area. PNNL-14119, Pacific Northwest National Laboratory, Richland, Washington.

Serne RJ, BN Bjornstad, PD Thorne, JM Keller, DC Lanigan, JN Christensen, and GS Thomas. 2010. Conceptual Models for Migration of Key Groundwater Risk Contaminants Through the Vadose Zone and Into the Upper Unconfined Aquifer Below the B-Complex. PNNL-19277, Pacific Northwest National Laboratory, Richland, Washington.

Shaw J, M Munro-Stasuik, B Sawyer, C Beaney, J-E Lesemann, A Musacchio, B Rains, and RR Young. 1999. "The Channeled Scabland: Back to Bretz." Geology 27:605-608.

Smith GA. 1993. "Missoula Flood Dynamics and Magnitudes Inferred Form Sedimentology of SlackWater Deposits on the Columbia Plateau." Geological Society of America Bulletin 195:77-100.

Spane FA and WD Webber. 1995. Hydrochemistry and Hydrogeologic Conditions Within the Hanford Site Upper-Basalt Confined Aquifer System. PNL-10817, Pacific Northwest Laboratory, Richland, Washington.

Strait SR and BA Moore. 1982. "Geohydrology of the Rattlesnake Ridge Interbed in the Gable Mountain Pond Area.” RHO-ST-38, Rockwell Hanford Operations, Richland, Washington. 
Tallman AM, KR Fecht, MC Marratt, and GV Last. 1979. Geology of the Separations Areas, Hanford Site, South-Central Washington. RHO-ST-23, Rockwell Hanford Operations, Richland, Washington.

Tallman AM, JT Lillie, and KR Fecht. 1981. "Suprabasalt Sediments of the Cold Creek Syncline Area." Chapter in Subsurface Geology of the Cold Creek Syncline Area, eds CW Myers, and SM Price.

RHO-BWI-ST-14, Rockwell Hanford Operations, Richland, Washington, pp. 2.1-2.28.

Thorne PD, MP Bergeron, MD Williams, and VL Freedman. 2006. Groundwater Data Package for Hanford Assessments. PNNL-14753, Rev. 1, Pacific Northwest National Laboratory, Richland, Washington.

Vermeul VR, CR Cole, MP Bergeron, PD Thorne, and SK Wurstner. 2001. Transient Inverse Calibration of Sitewide Groundwater Model to Hanford Operational Impacts from 1943 to 1996 Alternative Conceptual Model Considering Interaction with Uppermost Basalt Confined Aquifer. PNNL-13623, Pacific Northwest National Laboratory, Richland, Washington.

Waitt RB Jr. 1980. “About Forty Last-Glacial Lake Missoula Jokulhlaups Through Southern Washington." Journal of Geology 88:653-679.

Waitt, RB Jr. 1985. "Case for Periodic, Colossal Jokulhlaups from Pleistocene Glacial Lake Missoula." Geological Society of America Bulletin 96:1271-1286.

WHC - Westinghouse Hanford Company. 1992. Geologic Setting of the 200 East Area: An Update. WHC-SD-EN-TI-012, Rev. 0, prepared by BN Bjornstad, Pacific Northwest Laboratory; and KA Lindsey, JW Lindberg, KM Hoffman, and MP Connelly, Westinghouse Hanford Company, Richland, Washington.

Williams, BA, BN Bjornstad, R Schalla, and WD Webber. 2000. Revised Hydrogeology for the Suprabasalt Aquifer System, 200 East Area and Vicinity, Hanford Site, Washington. PNNL-12261, Pacific Northwest National Laboratory, Richland, Washington.

Wood MJ, TE Jones, R Schalla, BN Bjornstad, and SM Narbutovskih. 2000. Subsurface Conditions Description of the B-BX-BY Waste Management Area. HNF-5507, Rev. 0, CH2M HILL Hanford Group, Inc., Richland, Washington. 
Appendix A

Hydrogeologic Cross Sections 


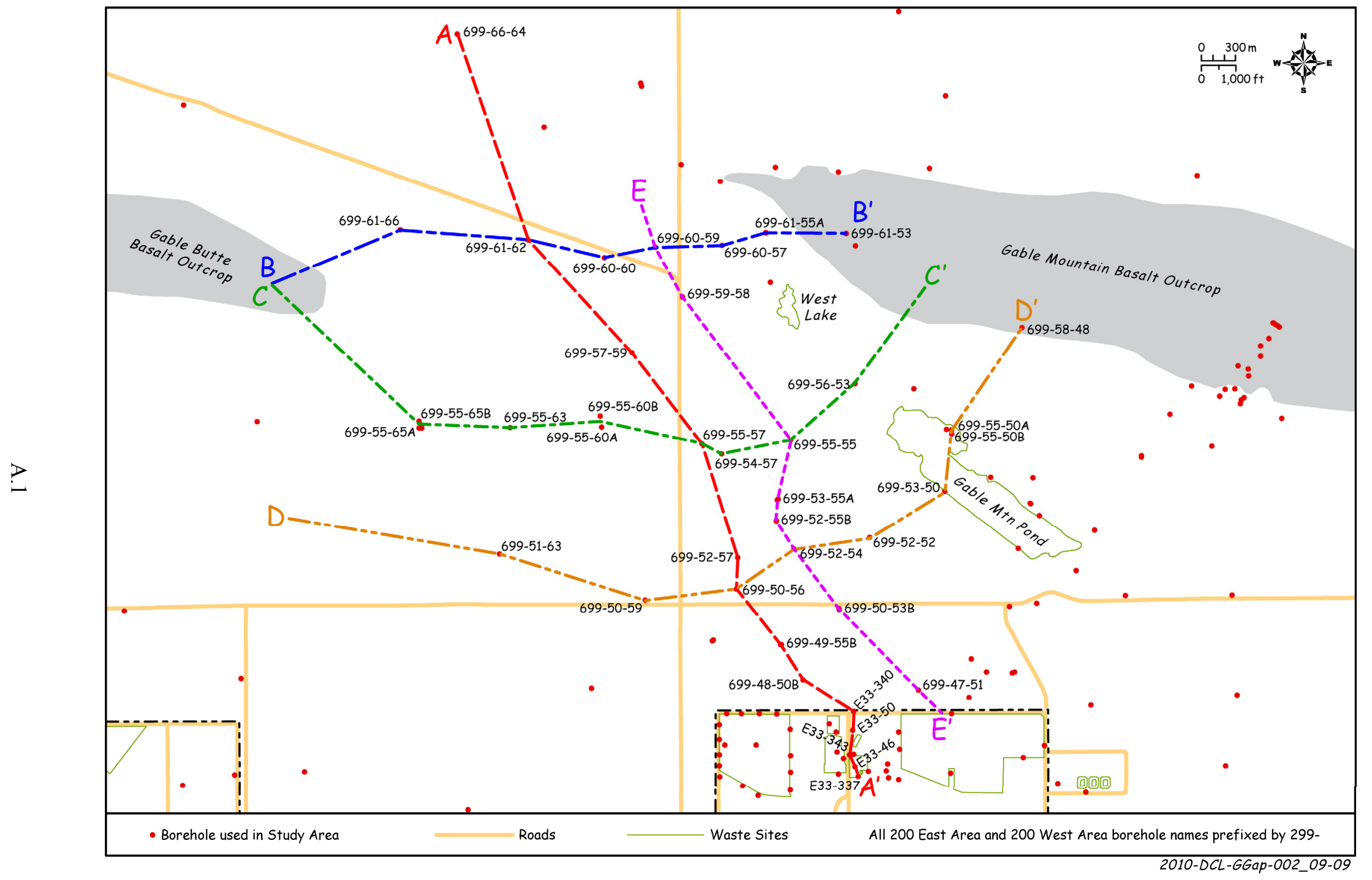

Figure A.1. Cross-section location map 


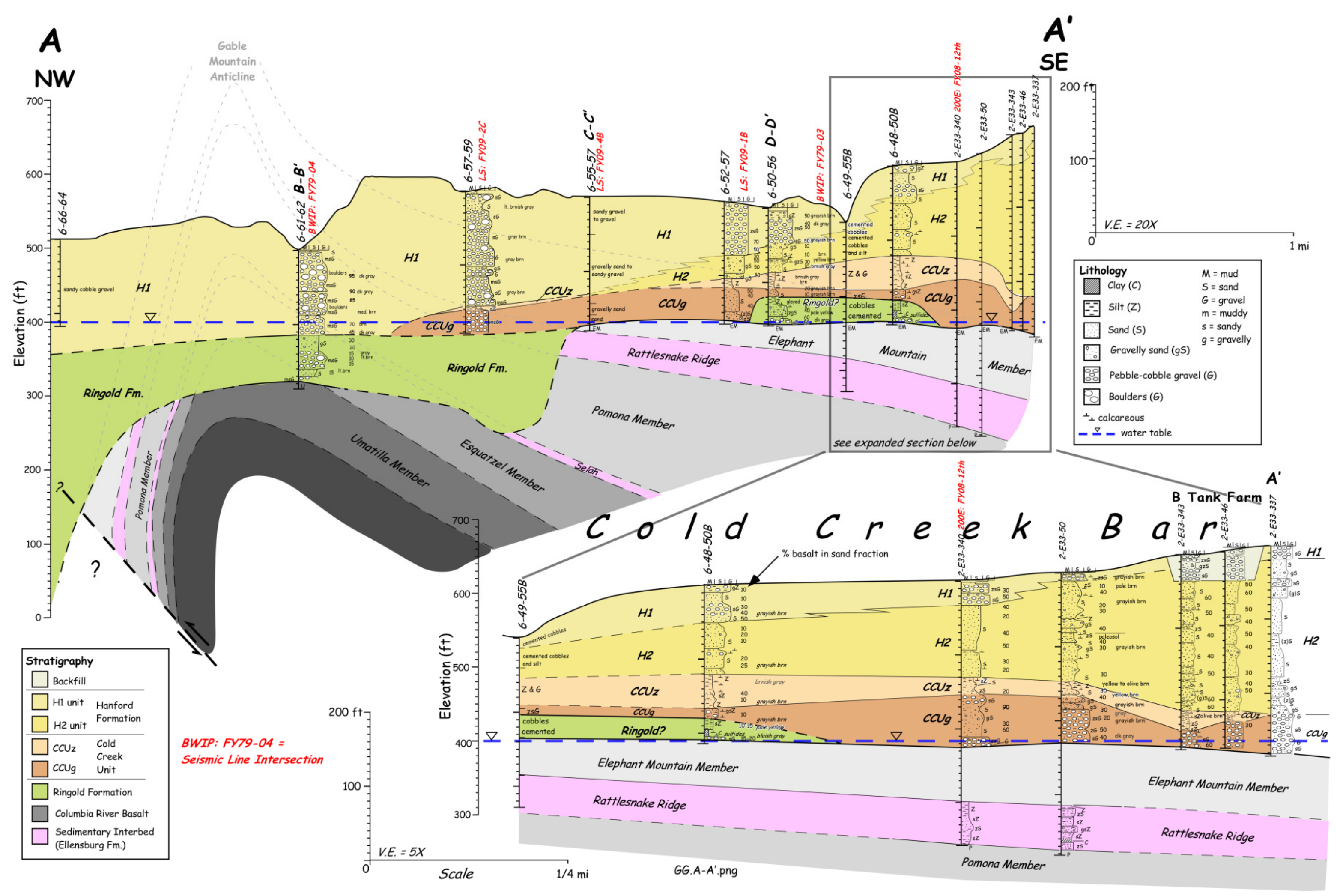

Figure A.2. Hydrogeologic cross section A-A' 


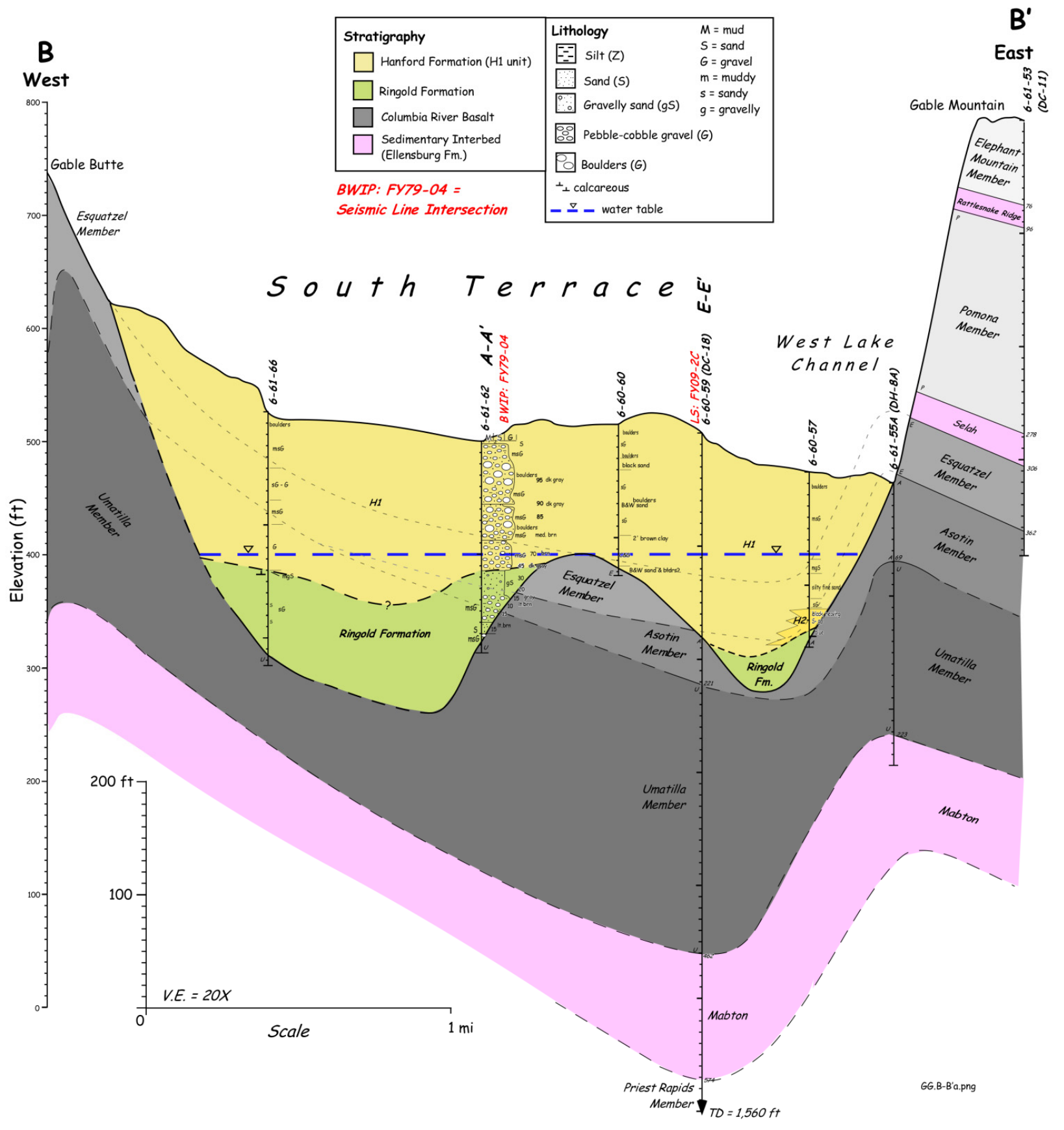

Figure A.3. Hydrogeologic cross section B-B' 


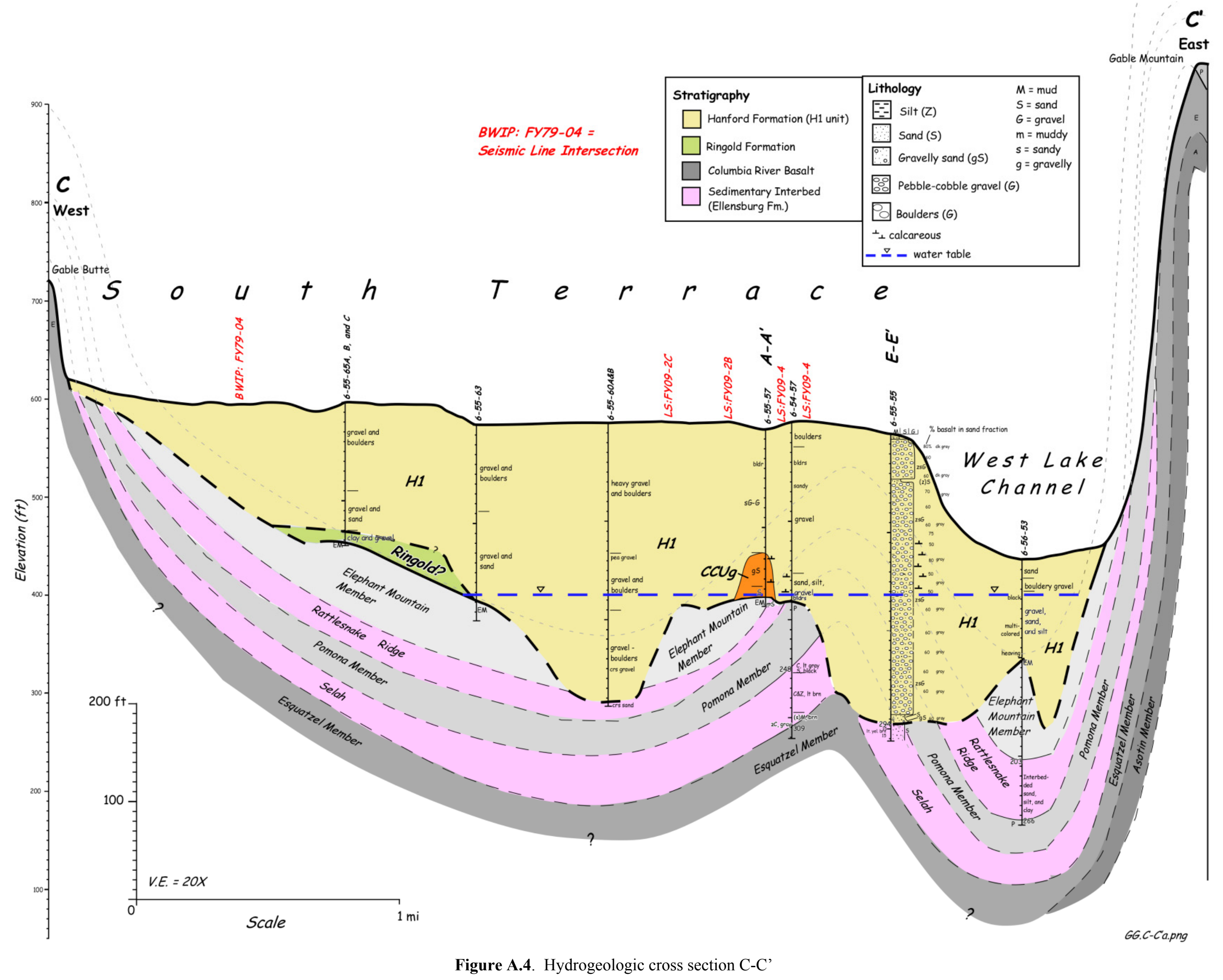




\begin{tabular}{|c|c|c|c|}
\hline $\begin{array}{l}\text { WWIP: FY79-04 = } \\
\text { Seismic Line Intersection }\end{array}$ & 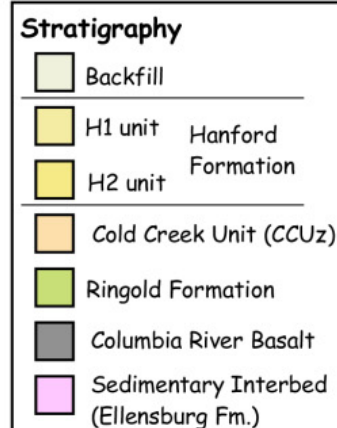 & 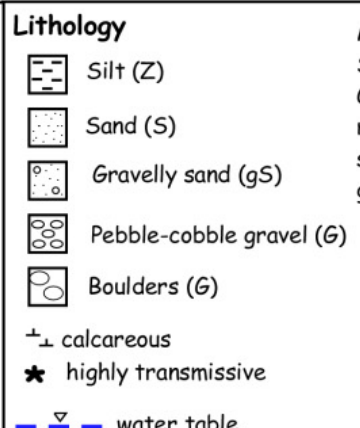 & 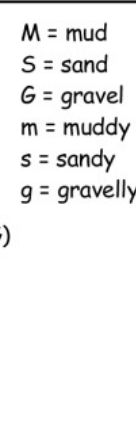 \\
\hline
\end{tabular}

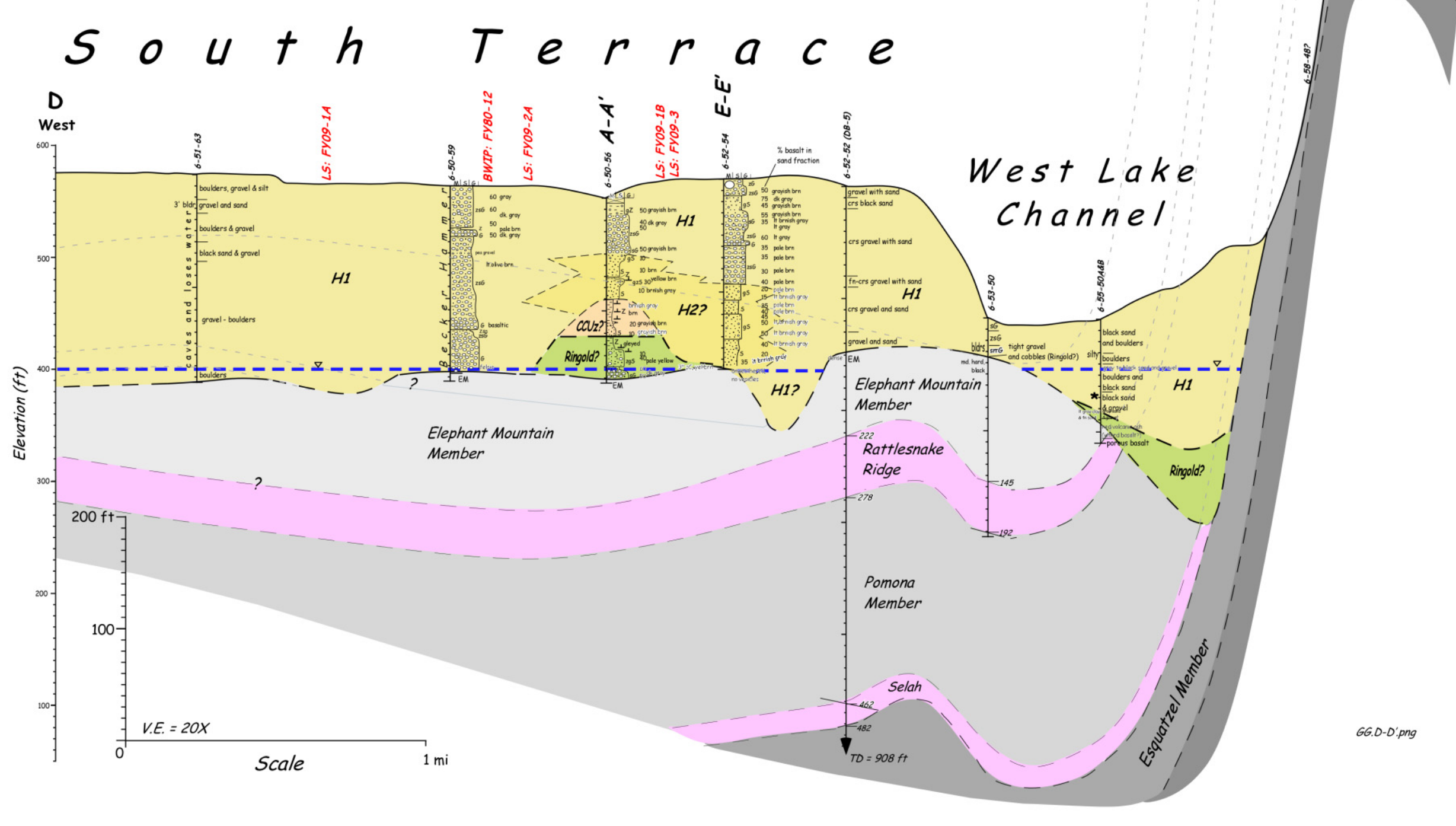

Figure A.5. Hydrogeologic cross section D-D 


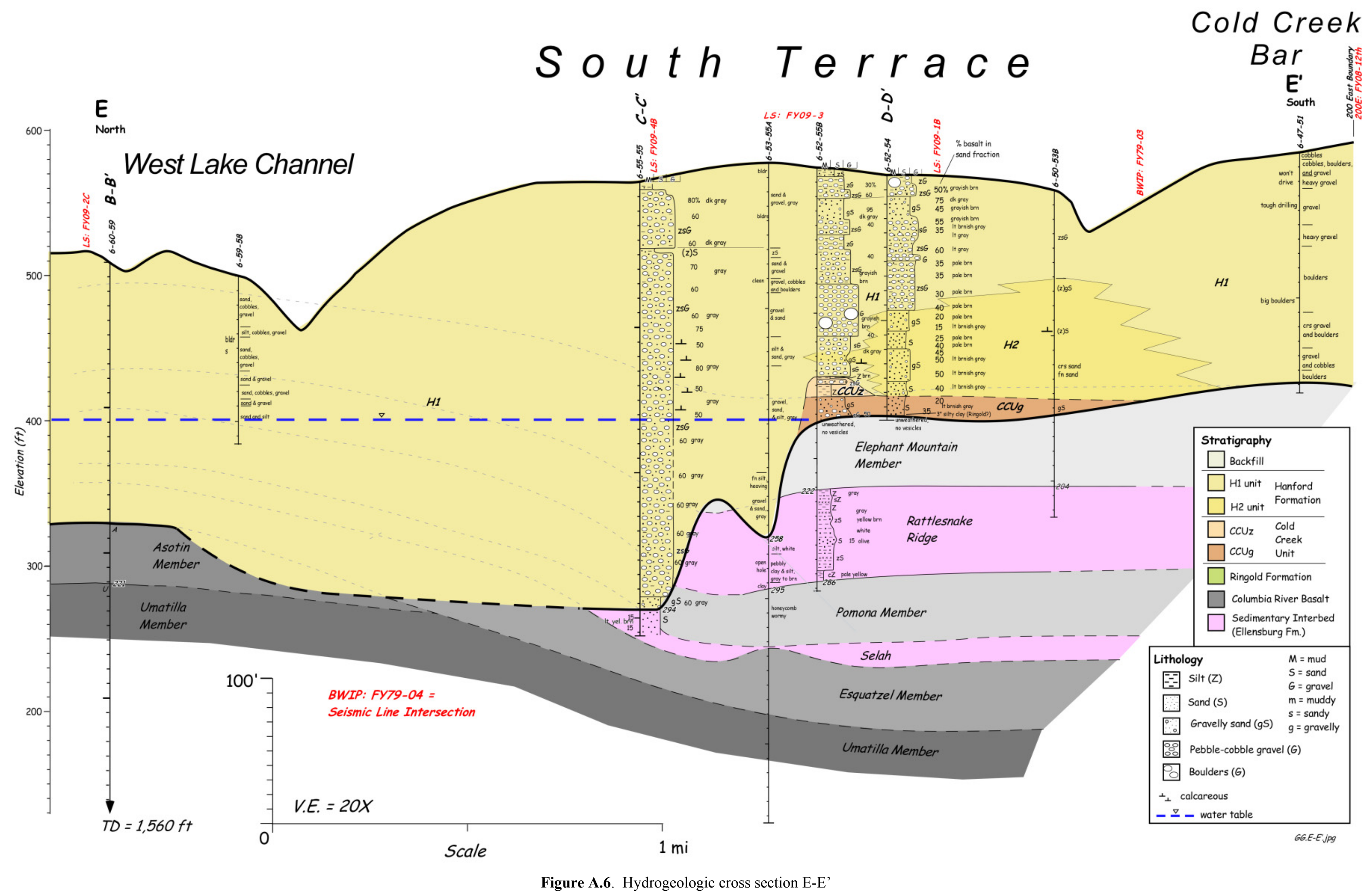




\section{Appendix B}

Structure-Contour Maps Based on EarthVision $®$ Model 


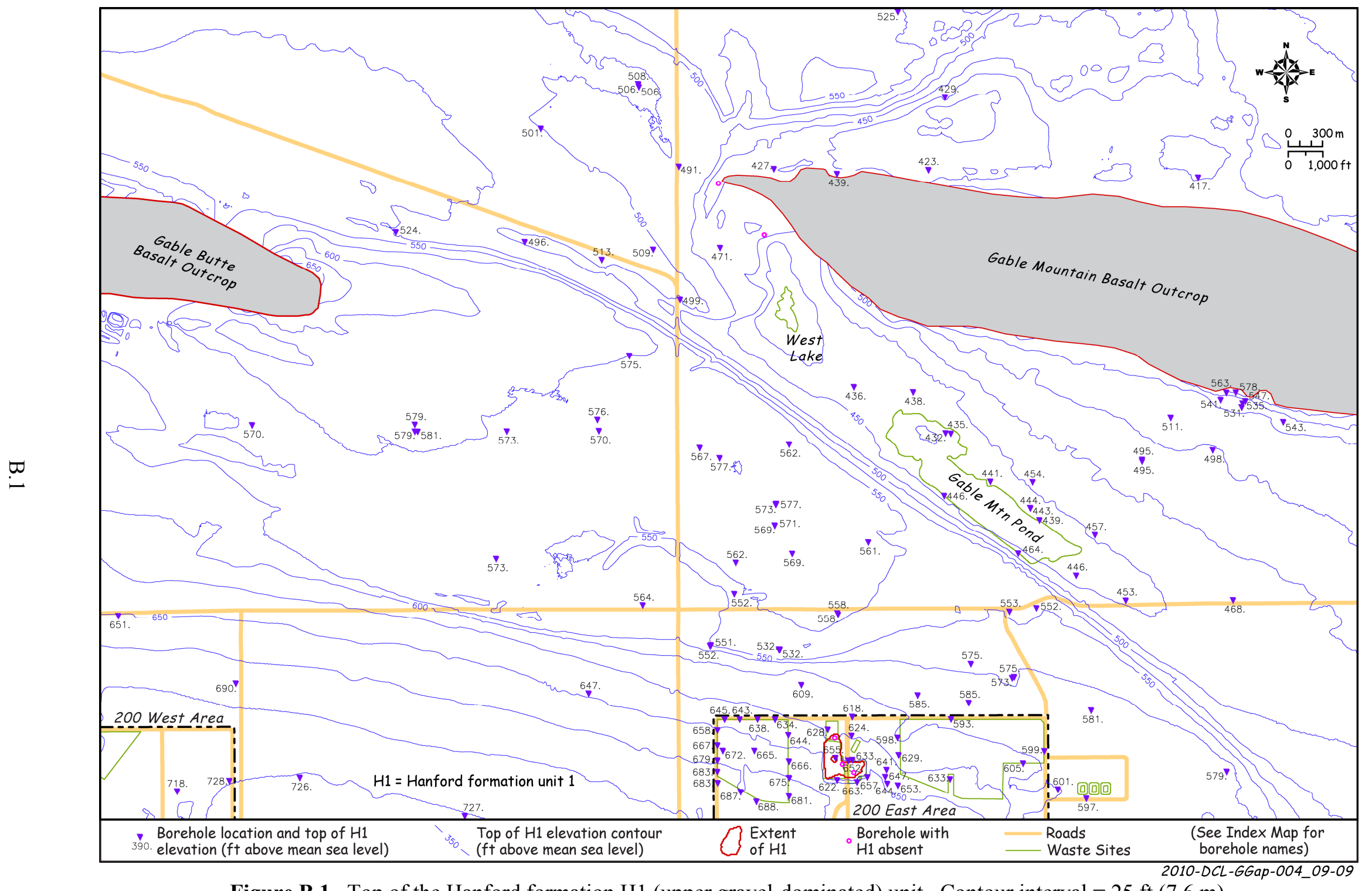

Figure B.1. Top of the Hanford formation H1 (upper gravel-dominated) unit. Contour interval $=25 \mathrm{ft}(7.6 \mathrm{~m})$ 


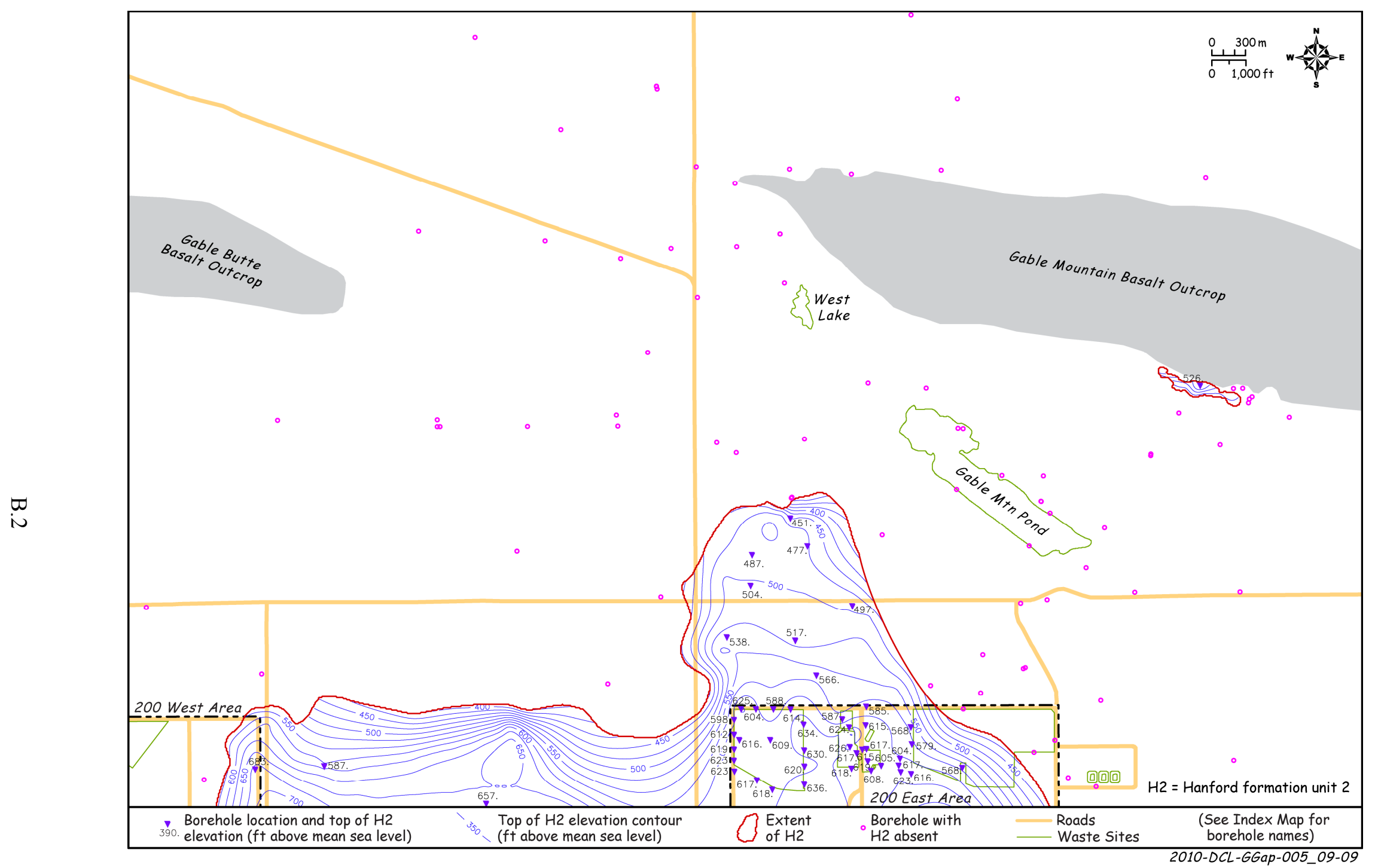

Figure B.2. Top of the Hanford formation H2 (sand-dominated) unit. Contour interval $=25 \mathrm{ft}(7.6 \mathrm{~m})$ 


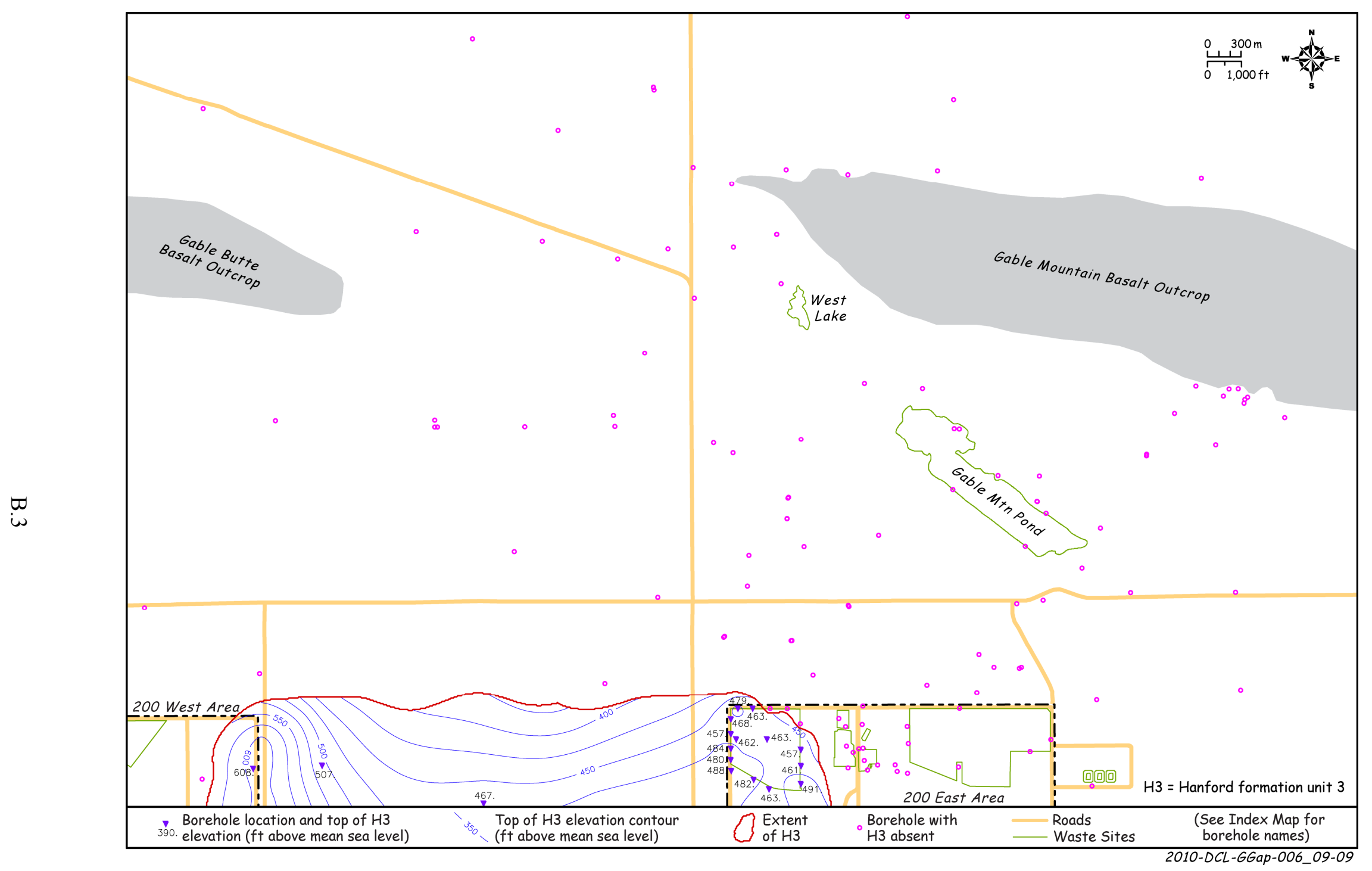

Figure B.3. Top of the Hanford formation H3 (lower gravel-dominated) unit. Contour interval $=25 \mathrm{ft}(7.6 \mathrm{~m})$. 


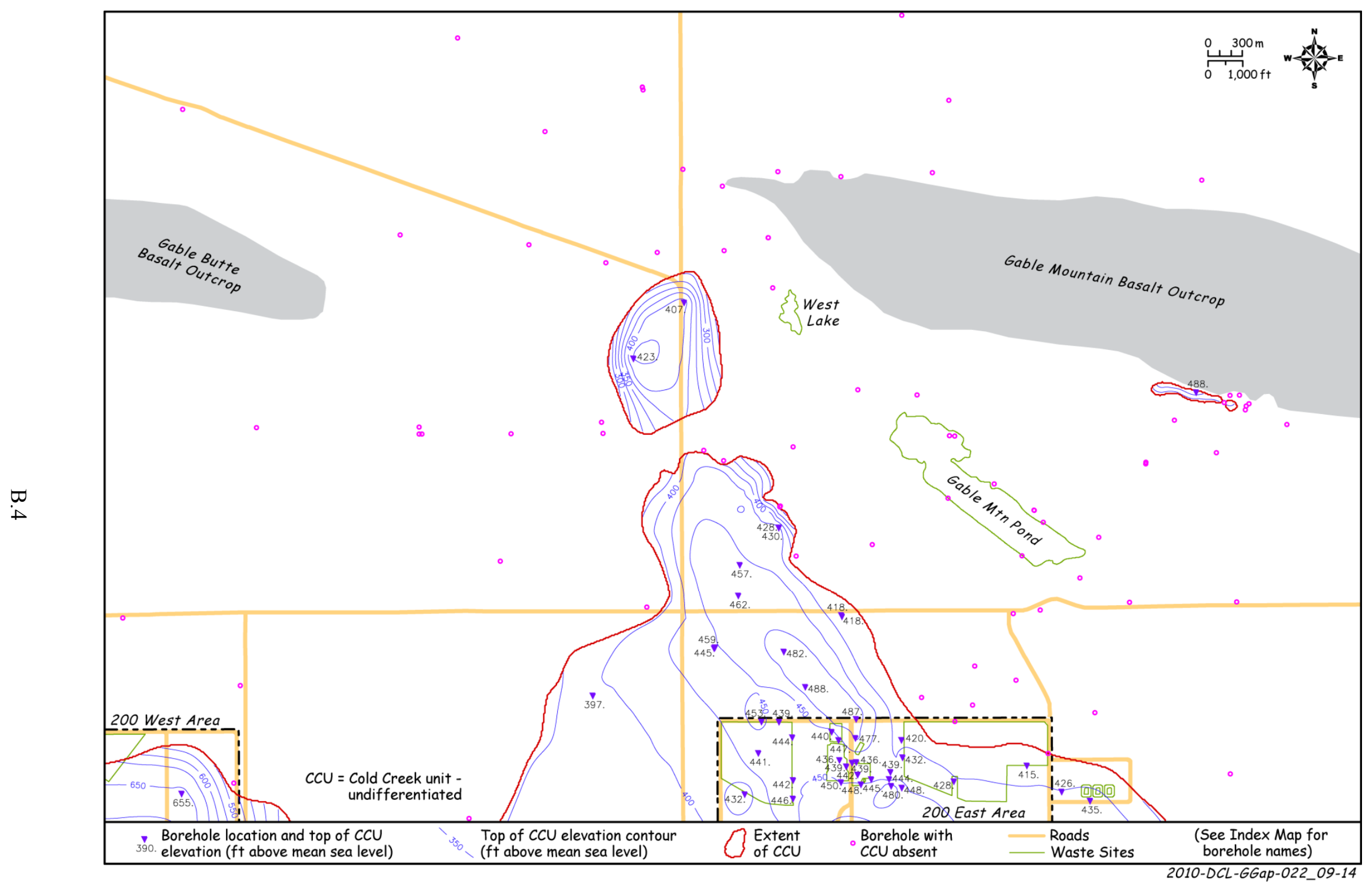

Figure B.4. Top of the Cold Creek unit (undifferentiated). Contour interval $=25 \mathrm{ft}(7.6 \mathrm{~m})$. 


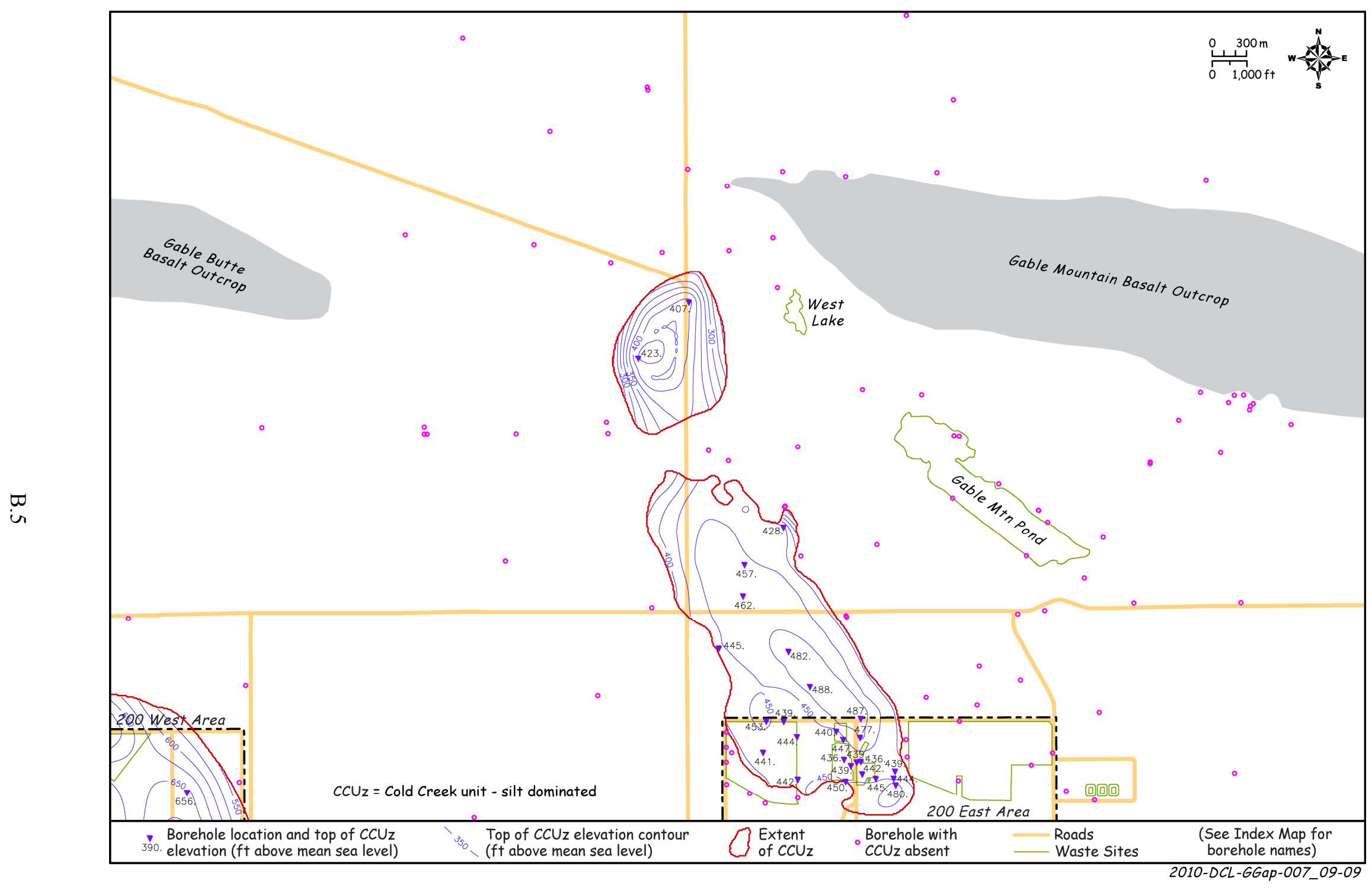

Figure B.5. Top of the Cold Creek silt $(\mathrm{CCUz})$ subunit. Contour interval $=25 \mathrm{ft}(7.6 \mathrm{~m})$. 


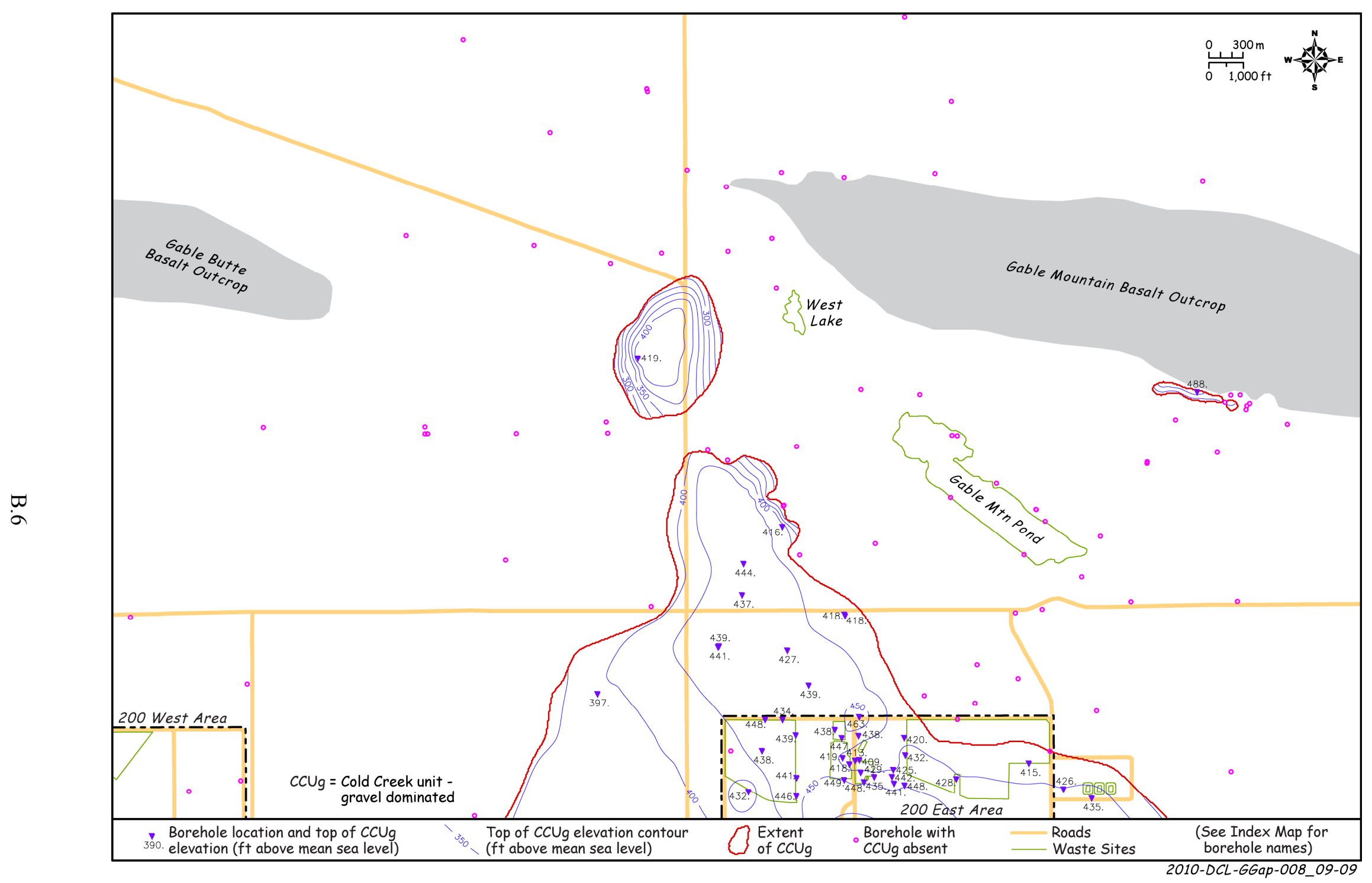

Figure B.6. Top of the Cold Creek gravel (CCUg) subunit. Contour interval $=25 \mathrm{ft}(7.6 \mathrm{~m})$. 


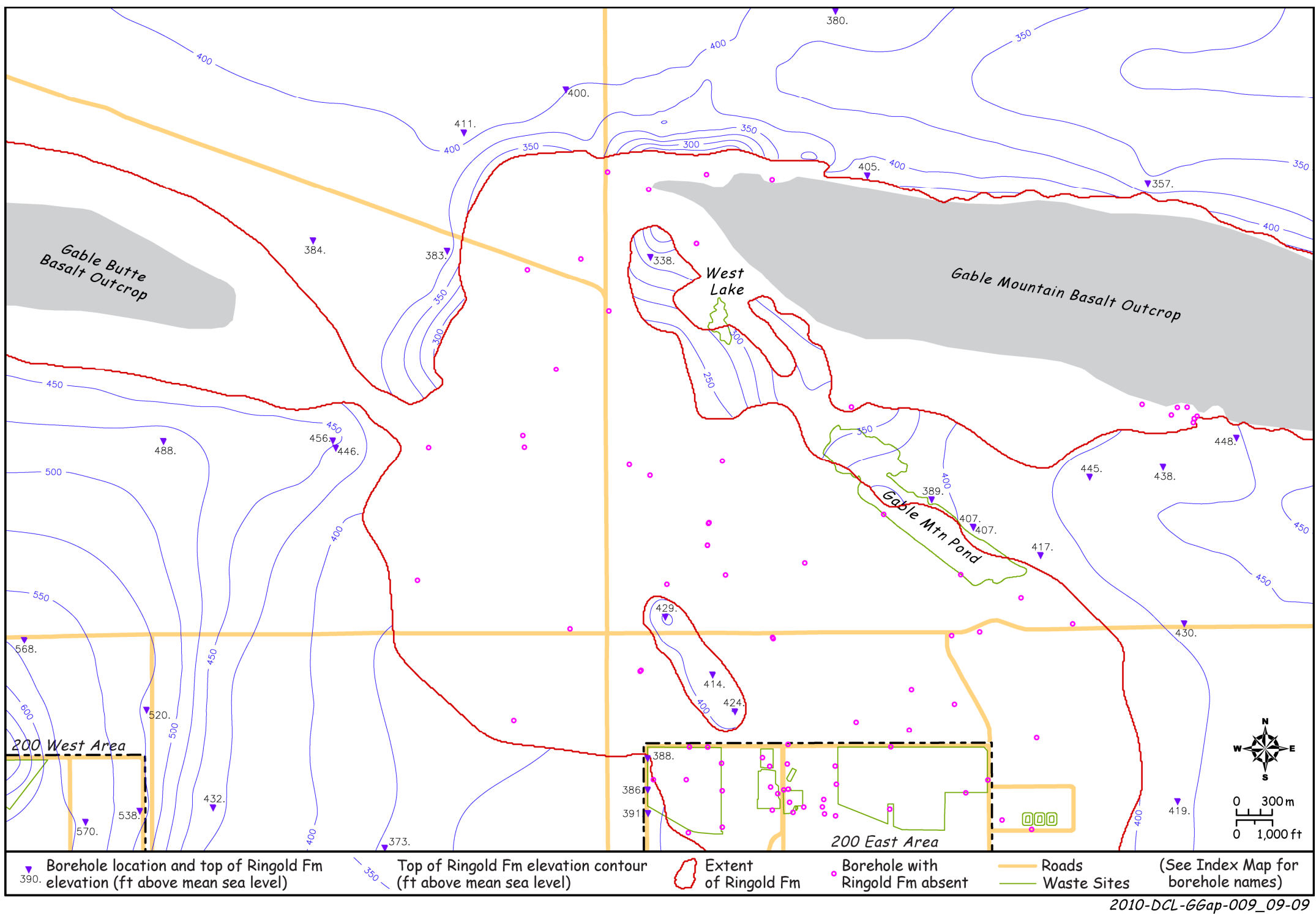

Figure B.7. Top of the Ringold Formation (undifferentiated). Contour interval $=25 \mathrm{ft}(7.6 \mathrm{~m})$. 


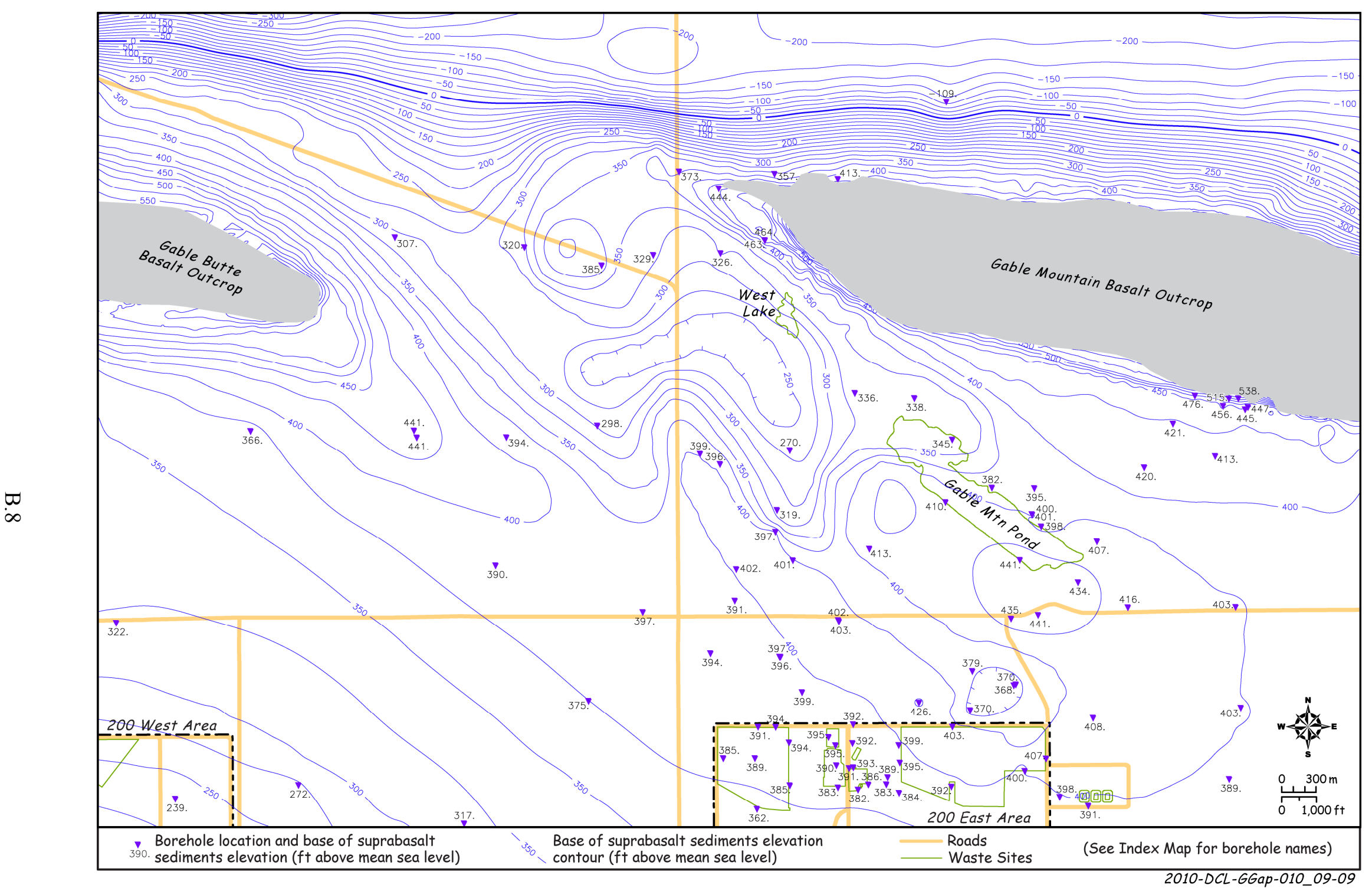

Figure B.8. Base of the suprabasalt sediments (top of the Columbia River Basalt Group and Ellensburg Formation - undifferentiated). Contour interval $=25 \mathrm{ft}(7.6 \mathrm{~m})$. 
Appendix C

Isopach Maps Based on EarthVision ${ }^{\circledR}$ Model 


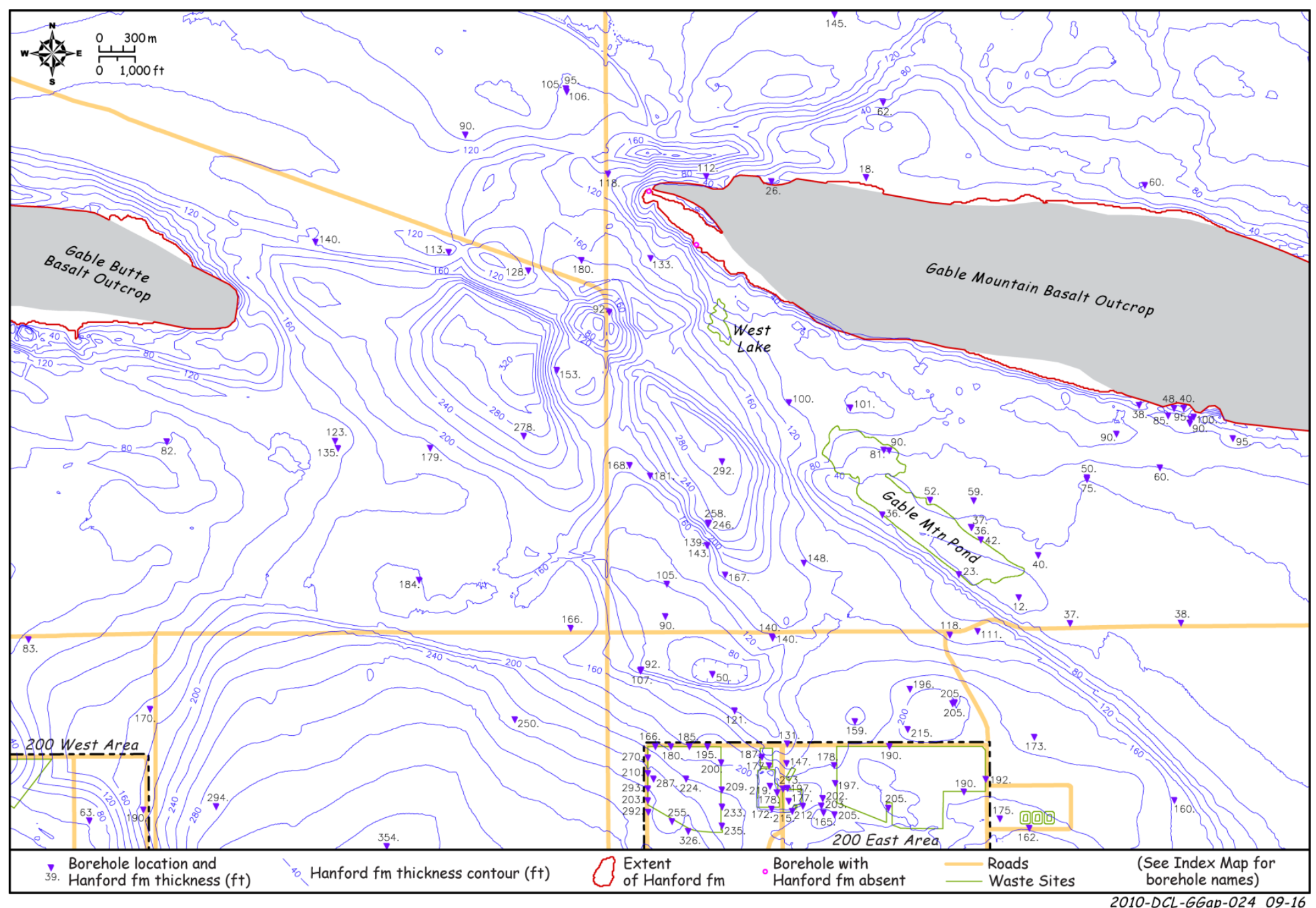

Figure C.1. Total thickness of the Hanford formation (undifferentiated). Contour interval $=20 \mathrm{ft}(6.1 \mathrm{~m})$ 


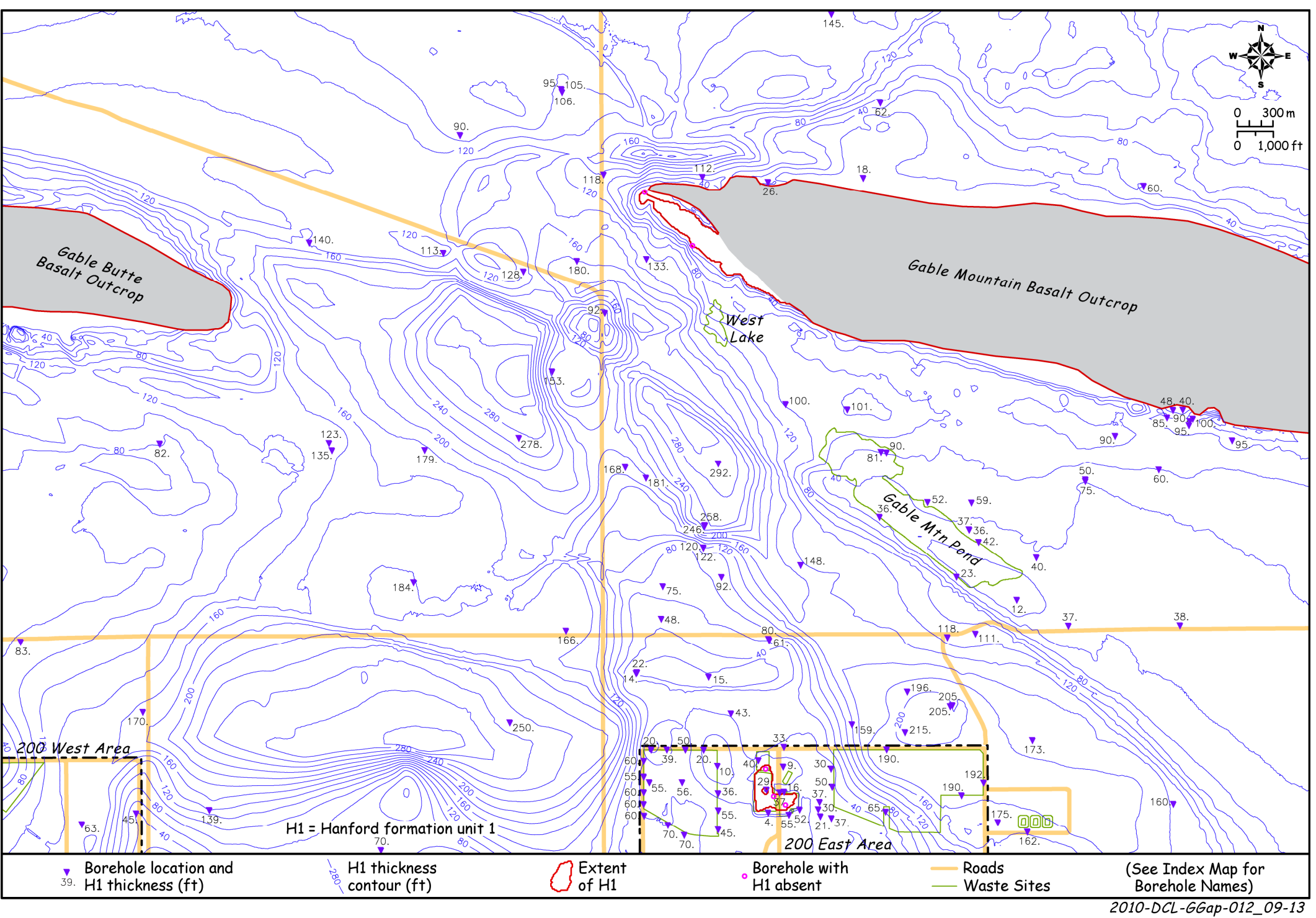

Figure C.2. Thickness of the Hanford formation H1 (upper gravel-dominated) unit. Contour interval $=20 \mathrm{ft}(6.1 \mathrm{~m})$. 


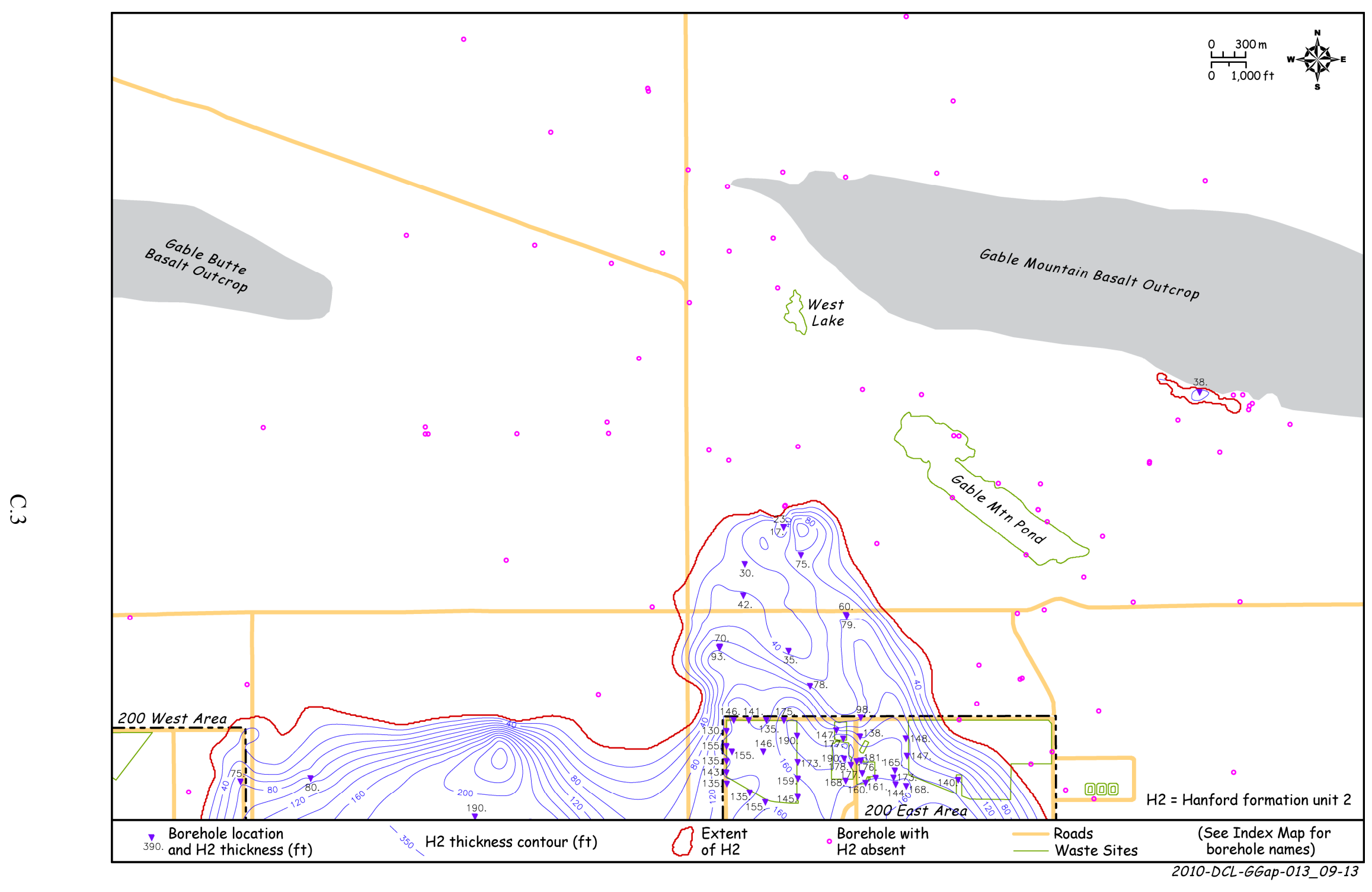

Figure C.3. Thickness of the Hanford formation H2 (sand-dominated) unit. Contour interval $=20 \mathrm{ft}(6.1 \mathrm{~m})$. 


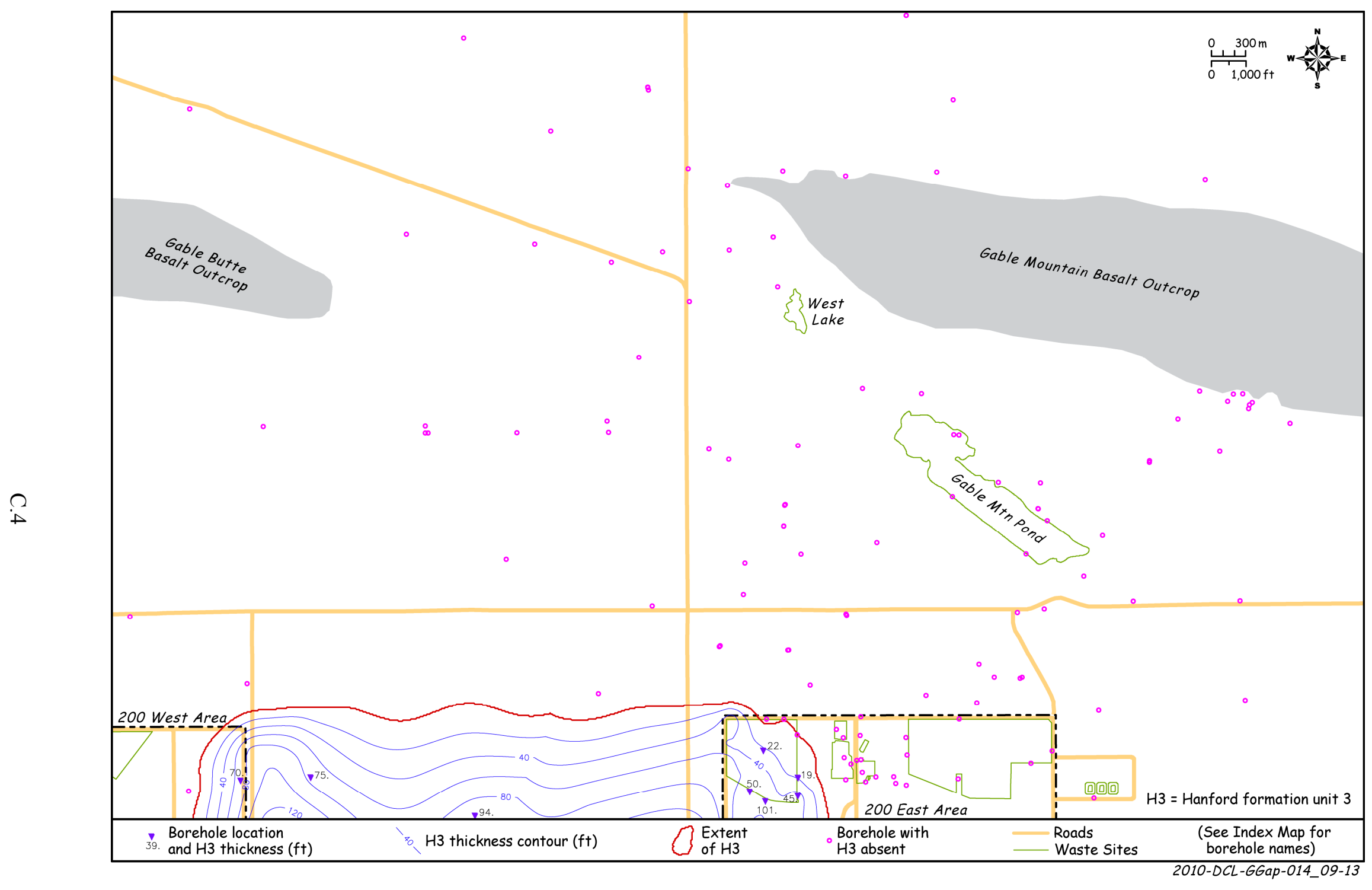

Figure C.4. Thickness of the Hanford formation H3 (lower gravel-dominated) unit. Contour interval $=20 \mathrm{ft}(6.1 \mathrm{~m})$. 


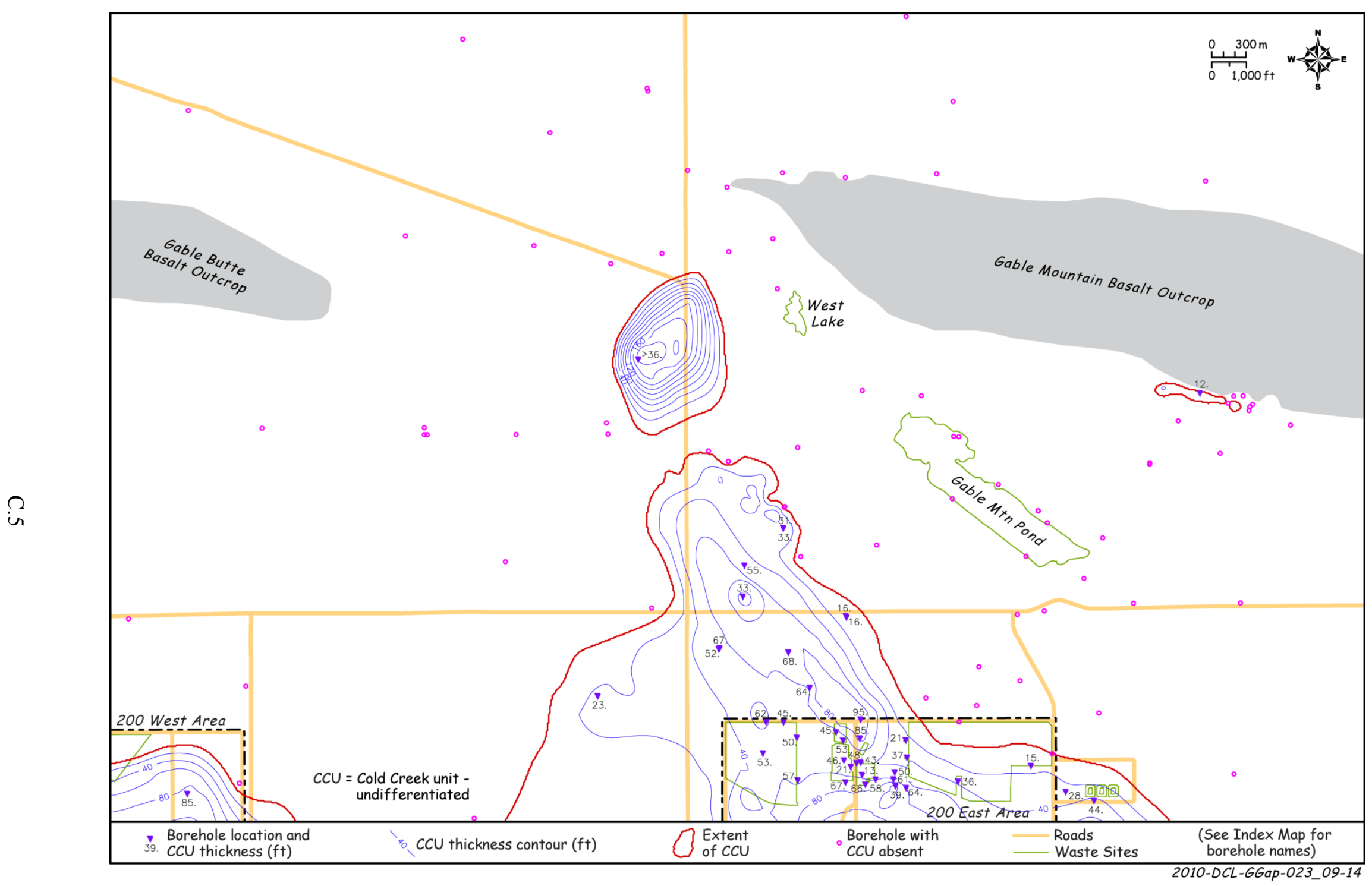

Figure C.5. Total thickness of the Cold Creek unit (undifferentiated). Contour interval $=20 \mathrm{ft}(6.1 \mathrm{~m})$. 


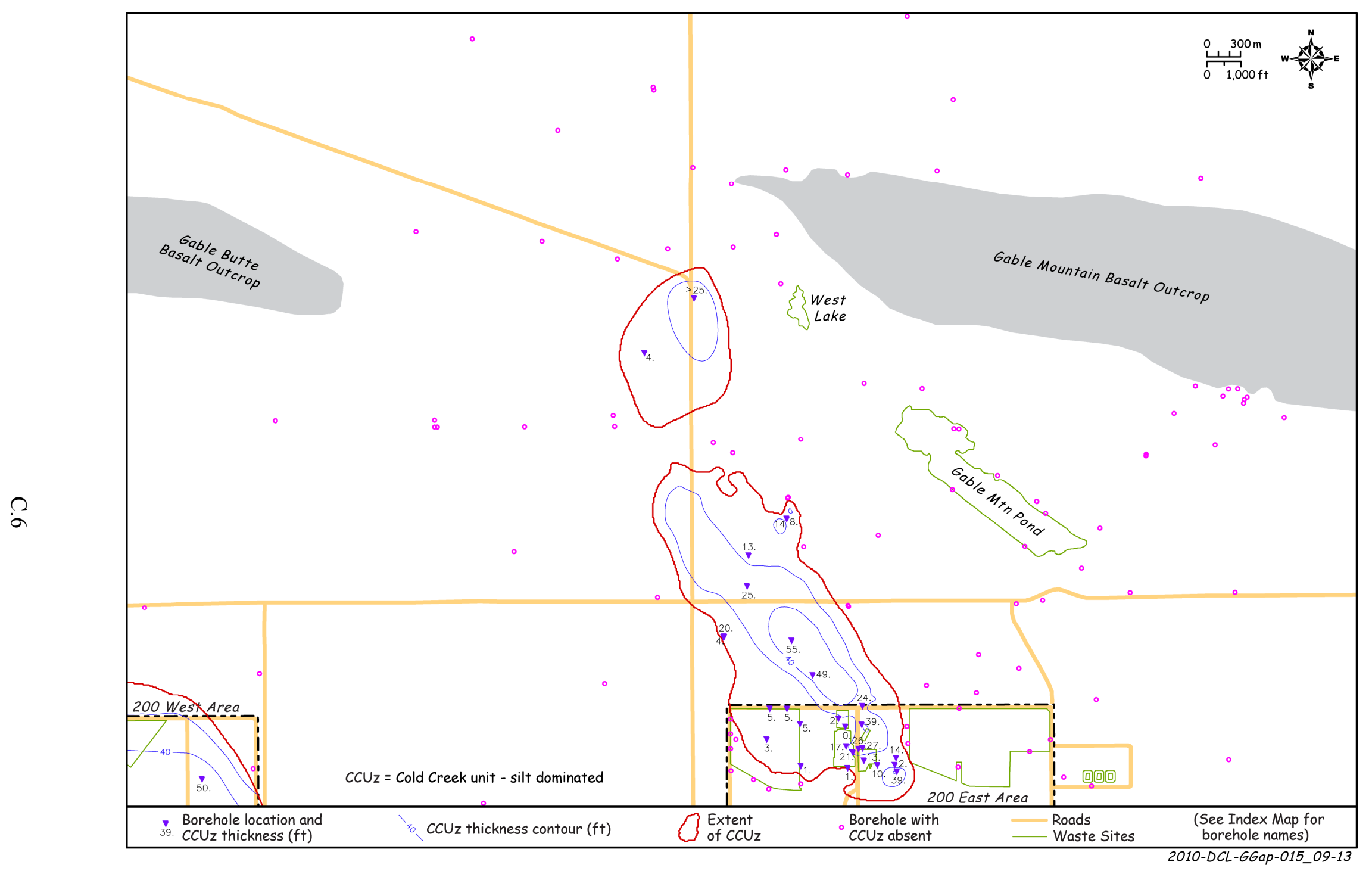

Figure C.6. Thickness of the Cold Creek silt (CCUz) subunit. Contour interval $=20 \mathrm{ft}(6.1 \mathrm{~m})$. 


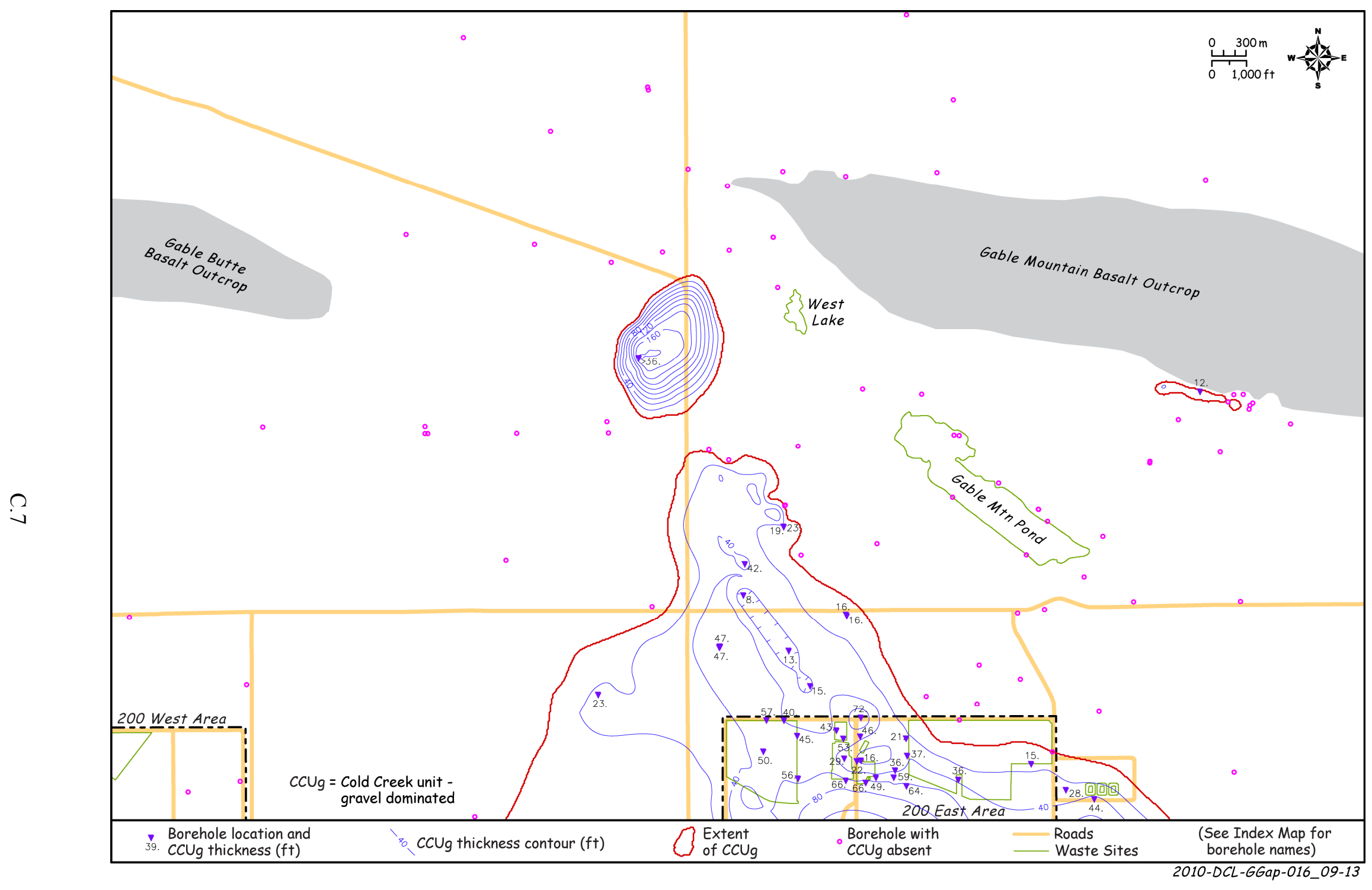

Figure C.7. Thickness of the Cold Creek gravel (CCUg) subunit. Contour interval $=20 \mathrm{ft}(6.1 \mathrm{~m})$. 


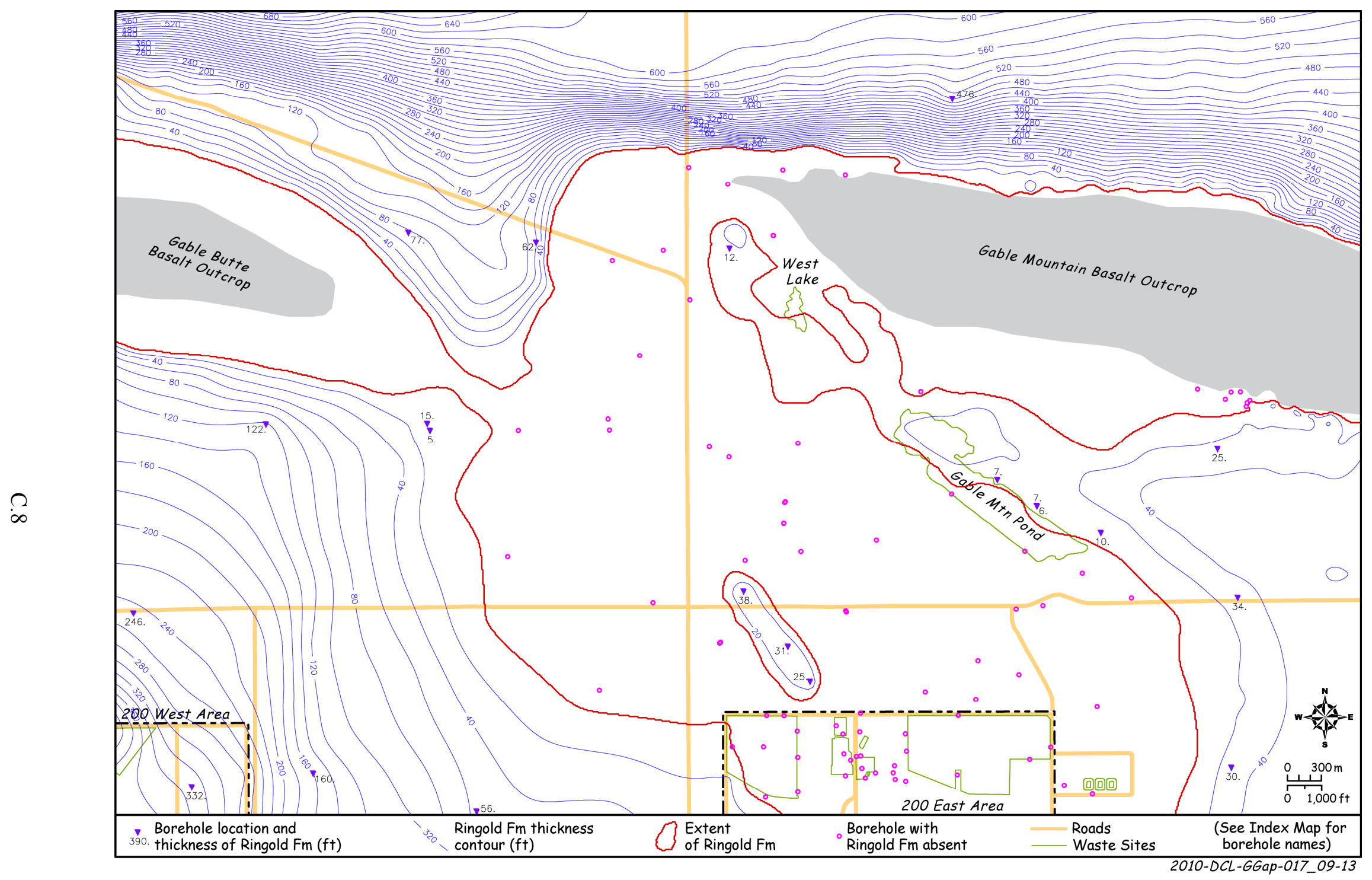

Figure C.8. Total thickness of the Ringold Formation (undifferentiated). Contour interval $=20 \mathrm{ft}(6.1 \mathrm{~m})$. 


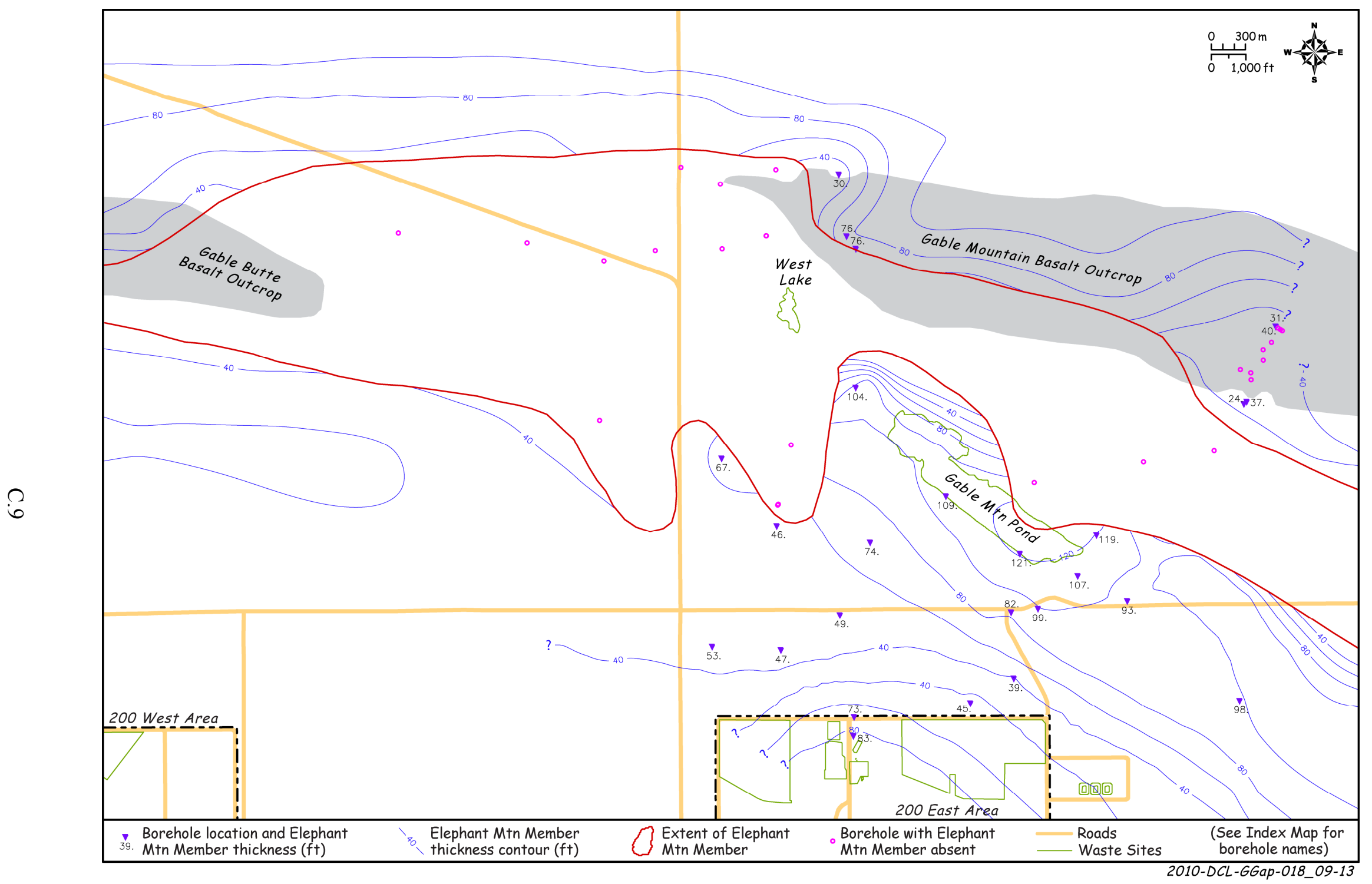

Figure C.9. Thickness of the Elephant Mountain Member basalt. Contour interval $=20 \mathrm{ft}(6.1 \mathrm{~m})$. 


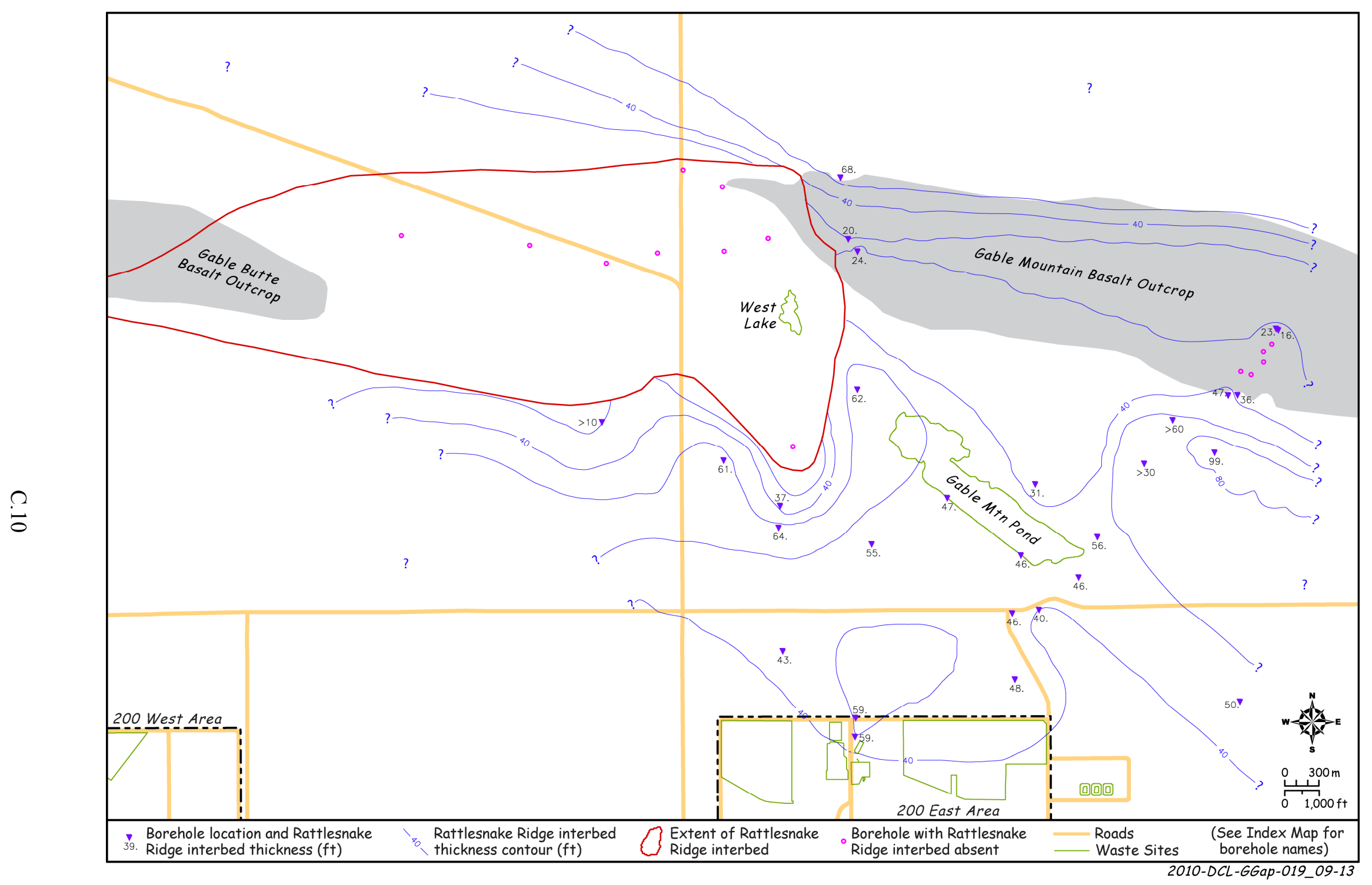

Figure C.10. Thickness of the Rattlesnake Ridge interbed (uppermost Ellensburg Formation). Contour interval $=20 \mathrm{ft}(6.1 \mathrm{~m})$. 
Appendix D

Three-dimensional EarthVision $®$ Model 


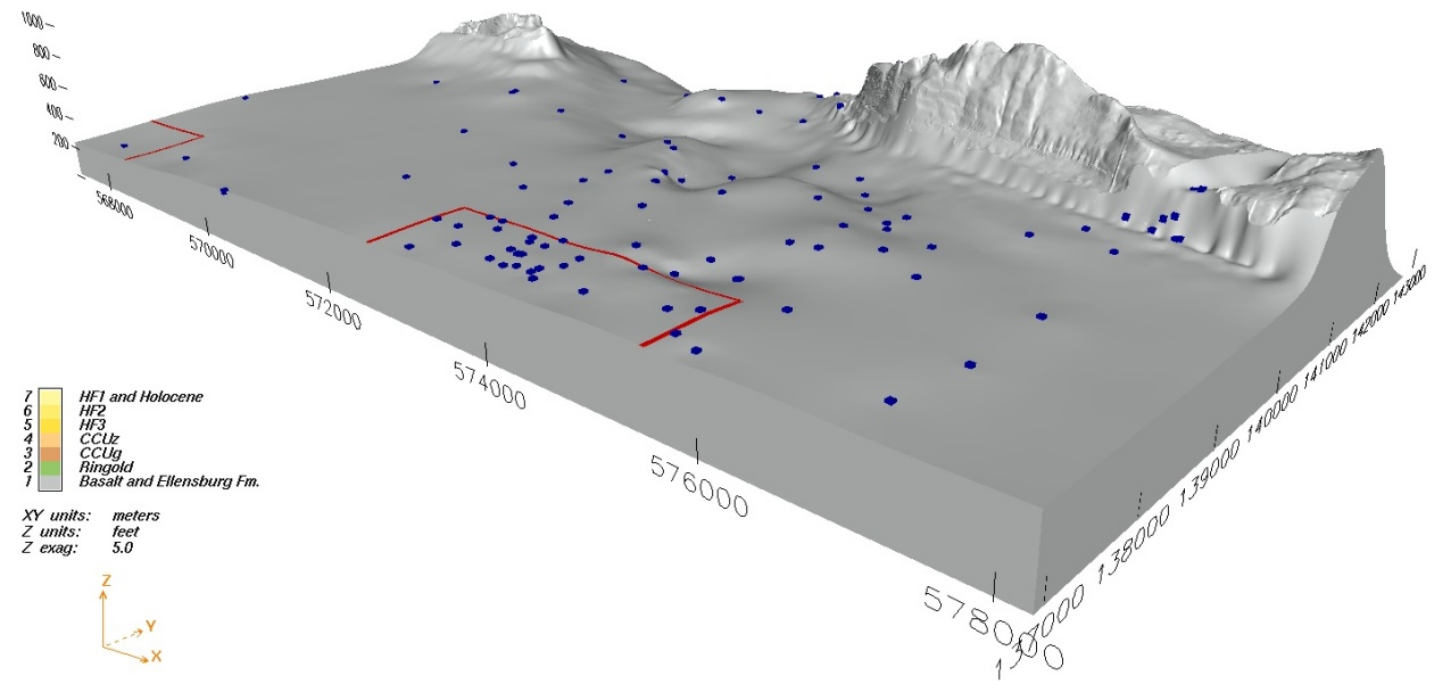

Figure D.1. Base of the suprabasalt sediments (top of Columbia River Basalt Group and Ellensburg Formation - undifferentiated). Oblique view looking northwest. Vertical exaggeration $=5 \mathrm{X}$.

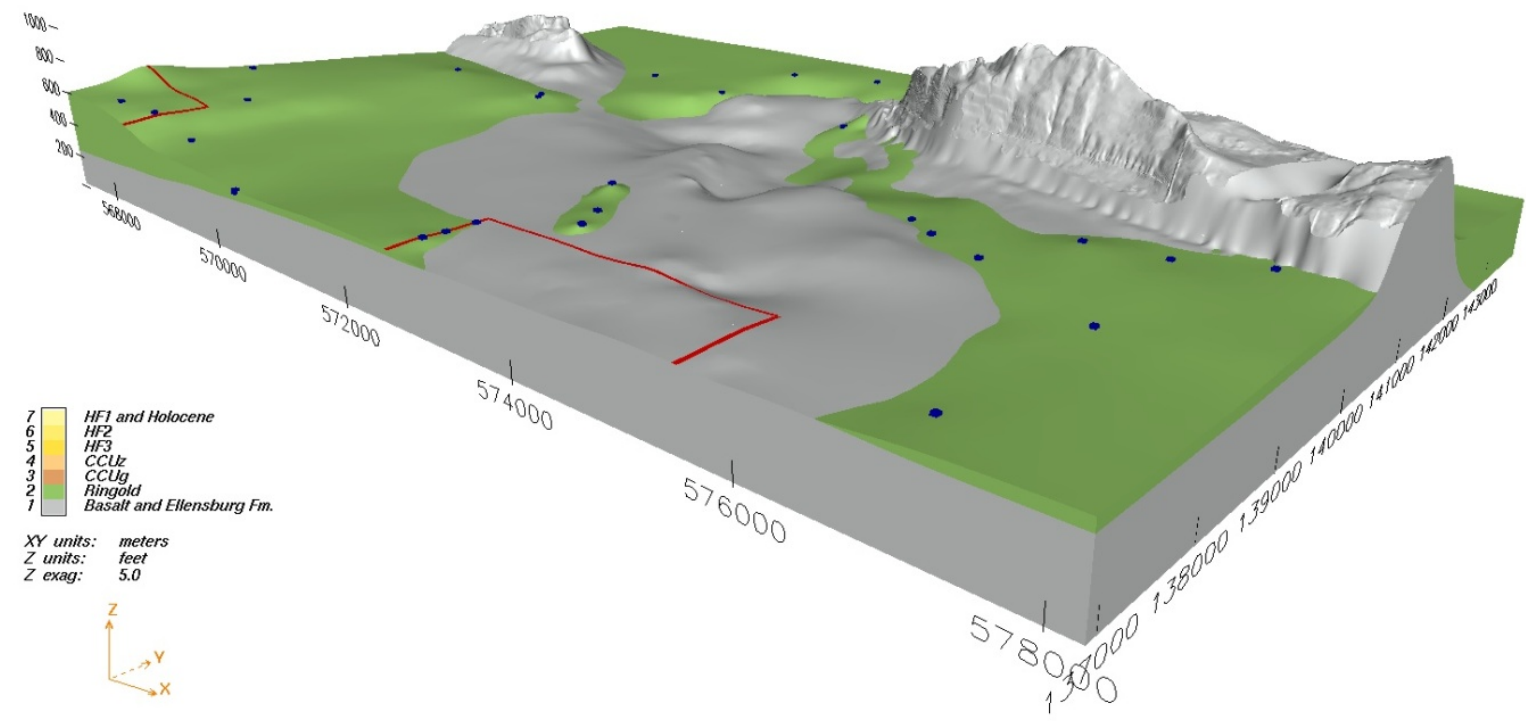

Figure D.2. Distribution of the Ringold Formation (undifferentiated). Oblique view looking northwest. Vertical exaggeration $=5 \mathrm{X}$. 


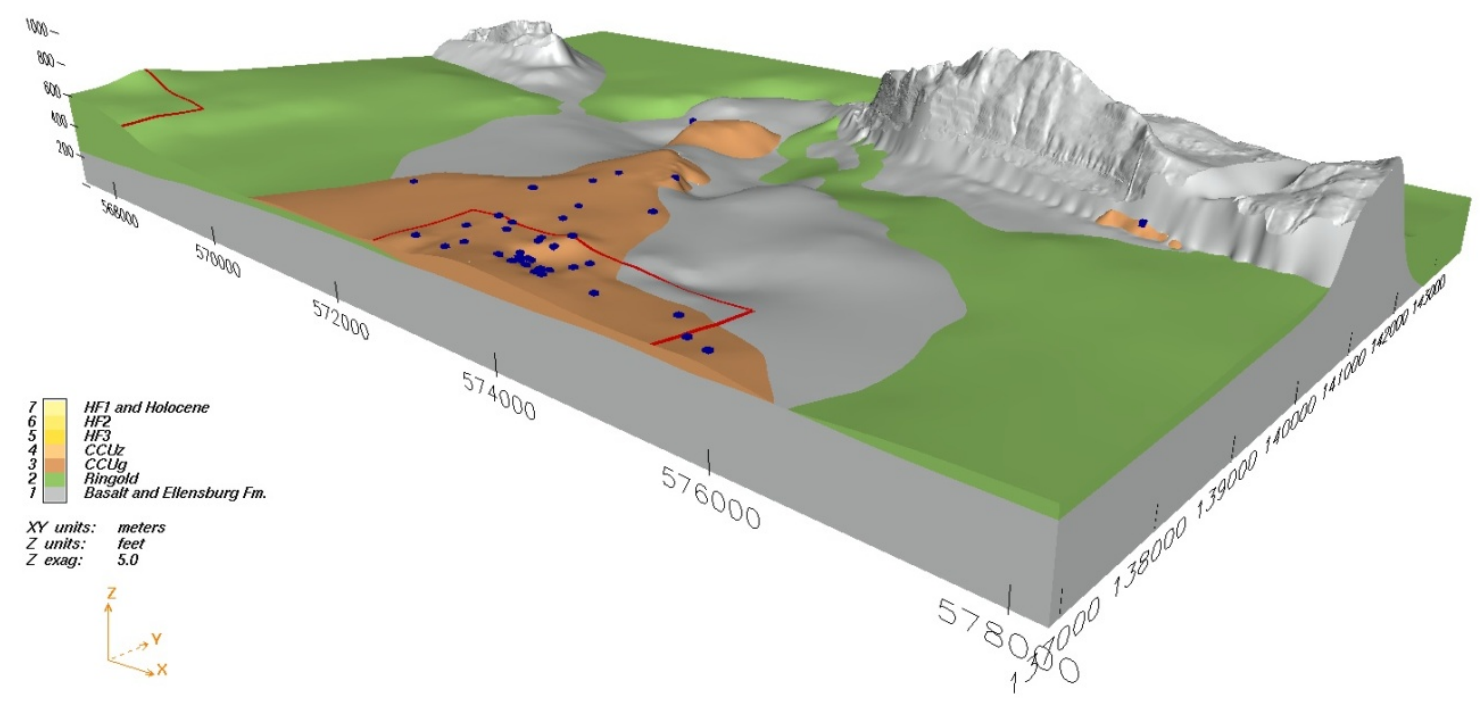

Figure D.3. Distribution of the Cold Creek gravel (CCUg) subunit. Oblique view looking northwest. Vertical exaggeration $=5 \mathrm{X}$.

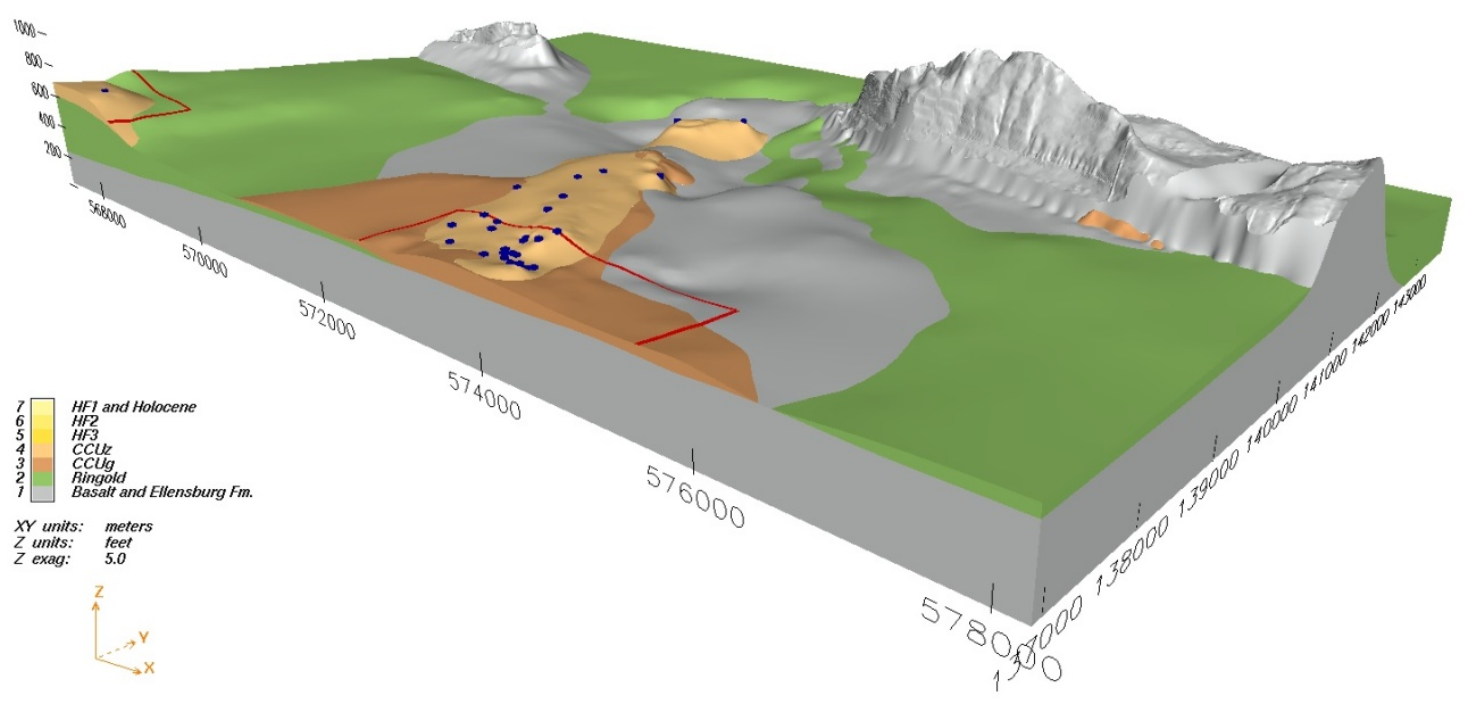

Figure D.4. Distribution of the Cold Creek silt (CCUz) subunit. Oblique view looking northwest. Vertical exaggeration $=5 \mathrm{X}$. 


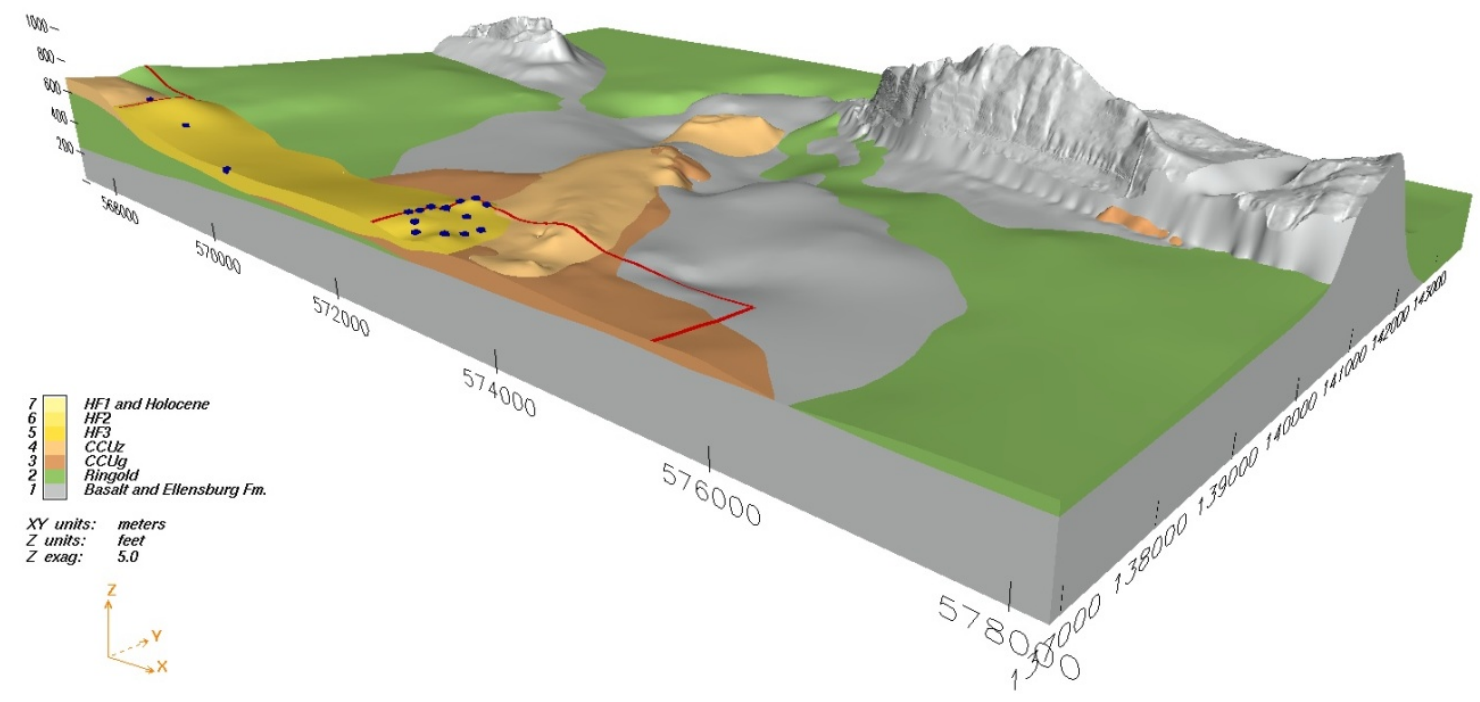

Figure D.5. Distribution of the Hanford formation H3 (lower gravel-dominated) unit. Oblique view looking northwest. Vertical exaggeration $=5 \mathrm{X}$.

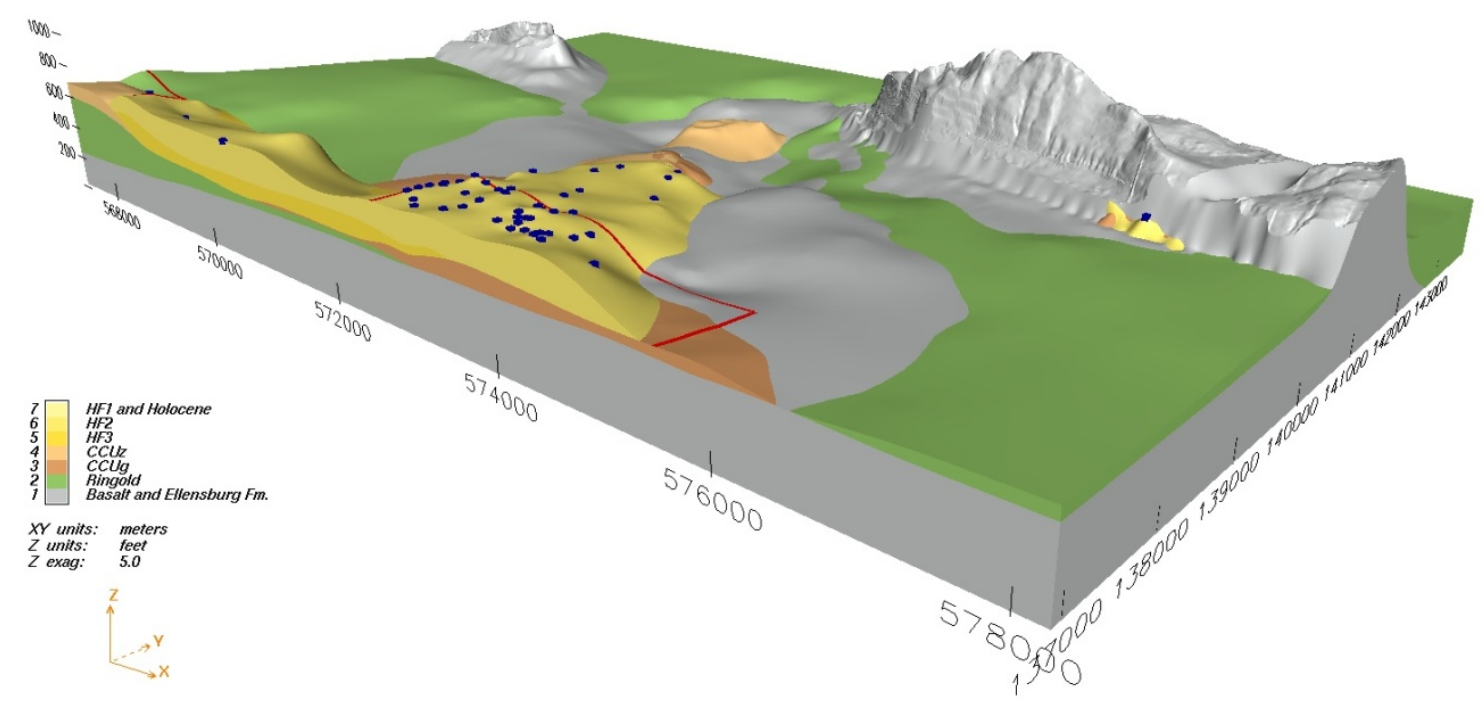

Figure D.6. Distribution of the Hanford formation H2 (sand-dominated) unit. Oblique view looking northwest. Vertical exaggeration $=5 \mathrm{X}$. 


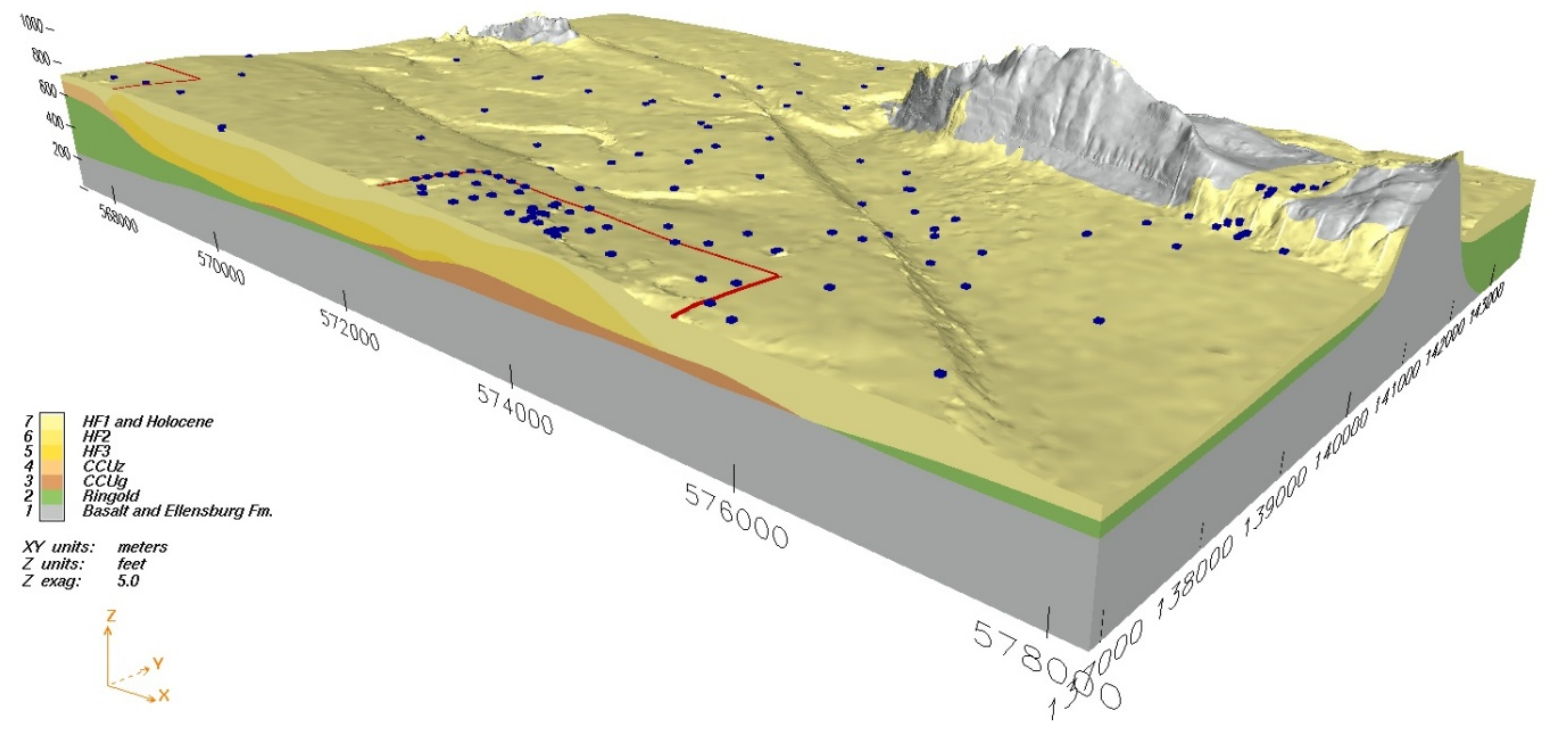

Figure D.7. Distribution of the combined Hanford formation H1 (upper gravel-dominated) unit and overlying Holocene deposits. Oblique view looking northwest. Vertical exaggeration $=5 \mathrm{X}$. 
Appendix E

Borehole Information and Tops of Stratigraphic Unit Contacts 
Table E.1. All Gable Gap Boreholes

\begin{tabular}{|c|c|c|c|c|c|c|c|c|c|c|c|c|c|c|c|c|c|c|c|c|}
\hline \multirow[b]{3}{*}{ Well Name } & \multicolumn{17}{|c|}{ Available Data } & \multicolumn{3}{|c|}{ Survey Data } \\
\hline & \multirow[b]{2}{*}{ 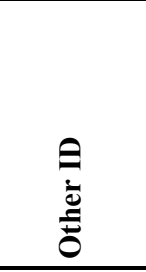 } & \multirow[b]{2}{*}{$\begin{array}{l}I \\
\bar{z} \\
\end{array}$} & \multirow{2}{*}{ 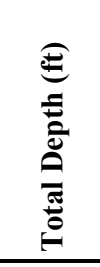 } & \multirow[b]{2}{*}{ 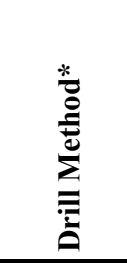 } & \multirow[b]{2}{*}{ 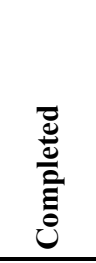 } & \multirow{2}{*}{ 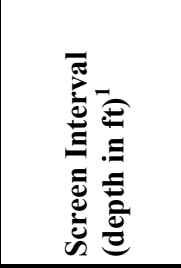 } & \multirow[b]{2}{*}{ 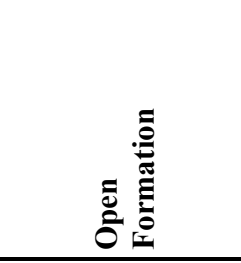 } & \multirow{2}{*}{ 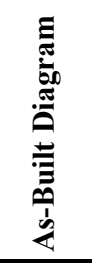 } & \multirow{2}{*}{ 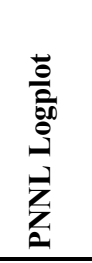 } & \multirow[b]{2}{*}{ 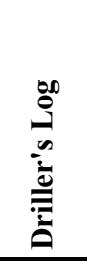 } & \multirow[b]{2}{*}{ 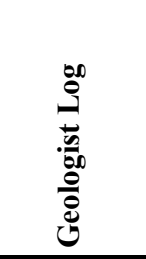 } & \multirow{2}{*}{ 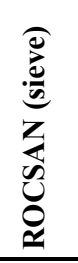 } & \multicolumn{3}{|c|}{ Geophysical Logs } & \multirow[b]{2}{*}{ 竧 } & \multirow[b]{2}{*}{ 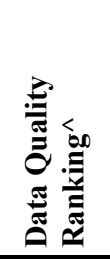 } & \multirow[b]{2}{*}{ 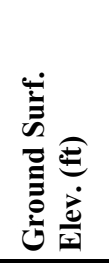 } & \multirow[b]{2}{*}{ 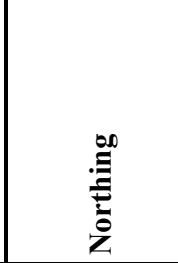 } & \multirow[b]{2}{*}{ 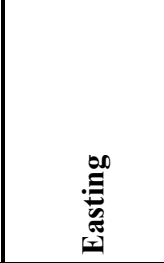 } \\
\hline & & & & & & & & & & & & & 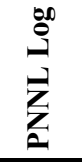 & 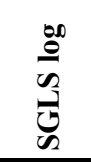 & 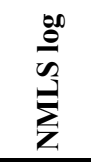 & & & & & \\
\hline 299-E26-77 & & C6455 & 224.8 & $\mathrm{DB}$ & 2008 & $200.8-225.6$ & $\begin{array}{l}\text { CCUg?/EM } \\
\end{array}$ & No & & No & Yes & No & No & Yes & Yes & & 1 & 603.2 & 137129.97 & 575579.26 \\
\hline 299-E26-79 & & C6826 & 224.8 & DB & 2008 & $195.2-220.2$ & CCUg/EM & No & & No & Yes & No & No & Yes & Yes & & 1 & 598.3 & 137027.55 & 575836.95 \\
\hline 299-E27-16 & & A4814 & 269 & $\mathrm{DB} / \mathrm{HT}$ & 1990 & $239-260$ & CCUg & Yes & & & No & No & Yes & No & No & & 3 & 652.8 & 137164.856 & 574179.237 \\
\hline 299-E28-26 & & A 4822 & 328.5 & $\mathrm{DB} / \mathrm{HT}$ & 1987 & 279-299 & CCUg & Yes & & Yes & Yes & Yes & Yes & No & No & & 2 & 688.4 & 137024.016 & 572941.553 \\
\hline 299-E28-27 & & $\mathrm{A} 4823$ & 301.5 & $\mathrm{HT} / \mathrm{DB}$ & 1987 & 270-290 & CCUg & Yes & & Yes & $\begin{array}{c}\text { Yes } \\
\text { (incomp) }\end{array}$ & Yes & Yes & No & No & & 3 & 681.4 & 137070.063 & 573226.784 \\
\hline 299-E28-28 & & A4824 & 296 & $\mathrm{DB} / \mathrm{HT}$ & 1990 & 275-295 & CCUg & Yes & & No & Yes & No & Yes & No & No & & 3 & 687.3 & 137108.259 & 572804.351 \\
\hline 299-E32-2 & & A 4830 & 289.2 & $\mathrm{DB} / \mathrm{HT}$ & 1987 & $258-289$ & CCUg & Yes & & Yes & Yes & Yes & Yes & No & No & & 2 & 671.5 & 137467.509 & 572648.02 \\
\hline 299-E32-3 & & A4831 & 304 & $\mathrm{HT} / \mathrm{DB}$ & 1987 & $266-301$ & CCUg/Ringold A & Yes & & No & Yes & Yes & Yes & No & No & & 2 & 678.9 & 137383.996 & 572600.614 \\
\hline 299-E32-4 & & A4832 & 311 & $\mathrm{DB} / \mathrm{HT}$ & 1987 & $278-308$ & CCUg/Ringold & Yes & & Yes & Yes & Yes & Yes & No & No & & 2 & 688.3 & 137187.218 & 572603.743 \\
\hline 299-E32-5 & & A4833 & 293.6 & $\mathrm{DB} / \mathrm{HT}$ & 1989 & 271-292 & CCUg & Yes & & Yes & Yes & Yes & Yes & No & No & & 2 & 682.7 & 137285.125 & 572599.697 \\
\hline 299-E32-6 & & A4834 & 278.8 & $\mathrm{DB} / \mathrm{HT}$ & 1991 & $254.5-275.5$ & $\mathrm{H} 3$ & Yes & & No & Yes & No & Yes & No & No & & 3 & 667.3 & 137515.1 & 572600.4 \\
\hline 299-E32-7 & & A4835 & 273.8 & DB & 1991 & $246-266$ & $\mathrm{H} 3$ & Yes & & No & Yes & No & Yes & No & No & & 2 & 658.2 & 137647.05 & 572600.38 \\
\hline 299-E32-8 & & A 4836 & 256.7 & DB & 1991 & $235-255$ & $\mathrm{H} 3$ ? & Yes & & No & Yes & No & Yes & No & No & & 2 & 645.5 & 137741.47 & 572663.39 \\
\hline 299-E32-9 & & A4837 & 254.6 & $\mathrm{DB} / \mathrm{HT}$ & 1991 & $231-251$ & $\mathrm{H} 3$ & Yes & Yes & No & Yes & Yes & Yes & No & No & & 2 & 643.1 & 137741.69 & 572795.11 \\
\hline 299-E32-10 & & A5432 & 245.8 & DB & 1992 & $225-245$ & $\mathrm{H} 3$ & Yes & Yes & No & Yes & Yes & Yes & No & No & & 2 & 638.2 & 137741.69 & 572951.13 \\
\hline 299-E33-28 & & A 4852 & 278.3 & $\mathrm{HT} / \mathrm{DB}$ & 1987 & $256-276$ & $\mathrm{H} 3$ & Yes & & Yes & Yes & Yes & Yes & No & No & & 3 & 666.2 & 137375.019 & 573226.365 \\
\hline 299-E33-29 & & A 4853 & 290 & $\mathrm{DB} / \mathrm{HT}$ & 1987 & $263-290$ & CCUg* & Yes & & Yes & Yes & Yes & Yes & No & No & & 2 & 675.0 & 137231.193 & 573227.858 \\
\hline 299-E33-30 & & A4855 & 280.1 & $\mathrm{DB} / \mathrm{HT}$ & 1987 & $267-277$ & CCUg & Yes & & Yes & Yes & Yes & Yes & No & No & & 2 & 665.5 & 137467.779 & 572923.796 \\
\hline 299-E33-33 & & A4858 & 252 & $\mathrm{DB} / \mathrm{HT}$ & 1989 & $227-247$ & CCUg & No & & No & Yes & No & Yes & No & No & & 2 & 640.7 & 137301.934 & 574080.137 \\
\hline 299-E33-34 & & A4859 & 240 & $\mathrm{DB} / \mathrm{HT}$ & 1990 & $219-239$ & CCUg & Yes & Yes & No & Yes & Yes & Yes & No & No & & 2 & 634.0 & 137740.427 & 573104.458 \\
\hline 299-E33-35 & & A 4860 & 250 & $\mathrm{DB} / \mathrm{HT}$ & 1990 & $228-249$ & CCUg & Yes & & No & Yes & Yes & Yes & No & No & & 3 & 643.6 & 137605.098 & 573220.798 \\
\hline 299-E33-36 & & A4861 & 264 & $\mathrm{DB} / \mathrm{HT}$ & 1990 & $234-255$ & CCUg & Yes & & No & Yes & No & Yes & No & No & & 2 & 647.2 & 137239.981 & 574068.54 \\
\hline 299-E33-45 & & C3269 & 261 & $\mathrm{DB} / \mathrm{SS}$ & 2001 & N/A & & Yes & Yes & No & Yes & No & No & Yes & Yes & $\begin{array}{l}\text { Core logs, } \\
\text { photos }\end{array}$ & 1 & 656.8 & 137347 & 573683 \\
\hline 299-E33-46 & & C3360 & 264.4 & $\mathrm{DB} / \mathrm{SS}$ & 2001 & N/A & & & & & & & & & & $\begin{array}{l}\text { Core logs, } \\
\text { photos }\end{array}$ & 1 & 657.3 & 137278.365 & 573792.553 \\
\hline 299-E33-49 & & C4261 & 288.8 & DB & 2004 & $263.5-283.5$ & CCUg & No & & No & Yes & No & No & Yes & Yes & & 1 & 666.8 & 137212.8 & 573647.48 \\
\hline 299-E33-50 & & C5195 & 381 & $\mathrm{DB} / \mathrm{SS}$ & 2006 & $316-331$ & RRI & No & & No & Yes & No & No & Yes & Yes & $\begin{array}{l}\text { Photos, lab } \\
\text { logs }\end{array}$ & 1 & 625.8 & 137599.3 & 573773.61 \\
\hline 299-E33-205 & "C" well & C5989 & 270.6 & DB & 2008 & $257.5-267.5$ & CCUg & No & & No & Yes & No & No & Yes & Yes & $\begin{array}{l}\text { Photos, lab } \\
\text { logs }\end{array}$ & 1 & 657.2 & 137406.22 & 573633.38 \\
\hline 299-E33-333 & & B8079 & 254 & $\mathrm{DB} / \mathrm{SS}$ & 1998 & None & N/A & No & & No & Yes & No & No & $?$ & $?$ & & 2 & 653.4 & 137181.278 & 574086.41 \\
\hline 299-E33-337 & & C3390 & 286 & $\mathrm{AR}$ & 2001 & $255-280$ & CCUg & No & & No & Yes & No & No & Yes & Yes & & 2 & 662.7 & 137193.87 & 573821.8 \\
\hline 299-E33-338 & & C3391 & 275.8 & $\mathrm{SS} / \mathrm{DB}$ & 2001 & 251-271 & CCUg & No & & No & Yes & No & No & Yes & Yes & $\begin{array}{c}\text { Core photos, } \\
\text { paleomag }\end{array}$ & 1 & 657.0 & 137238.24 & 573912.07 \\
\hline
\end{tabular}


Table E.1. (contd)

\begin{tabular}{|c|c|c|c|c|c|c|c|c|c|c|c|c|c|c|c|c|c|c|c|c|}
\hline \multirow[b]{3}{*}{ Well Name } & \multicolumn{17}{|c|}{ Available Data } & \multicolumn{3}{|c|}{ Survey Data } \\
\hline & \multirow[b]{2}{*}{$\begin{array}{l}\text { 离 } \\
\text { ప̃ }\end{array}$} & \multirow[b]{2}{*}{$\stackrel{\nexists}{\overline{0}}$} & \multirow[b]{2}{*}{ 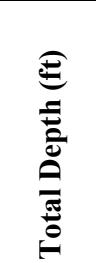 } & \multirow[b]{2}{*}{ 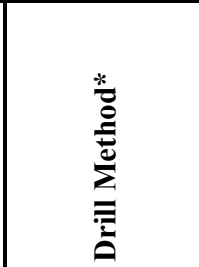 } & \multirow[b]{2}{*}{ 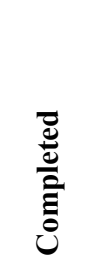 } & \multirow[b]{2}{*}{ 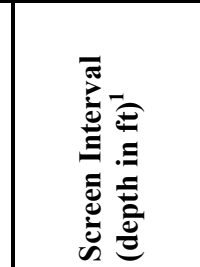 } & \multirow[b]{2}{*}{ 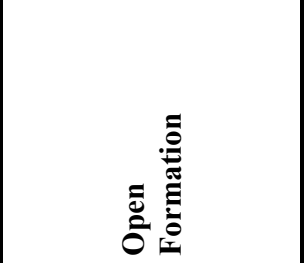 } & \multirow{2}{*}{ 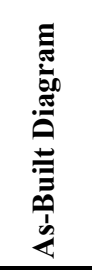 } & \multirow[b]{2}{*}{ 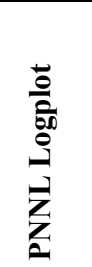 } & \multirow[b]{2}{*}{ 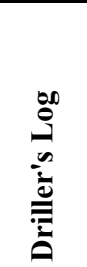 } & \multirow[b]{2}{*}{ 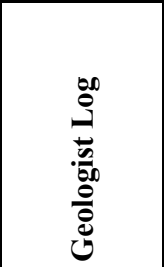 } & \multirow{2}{*}{ 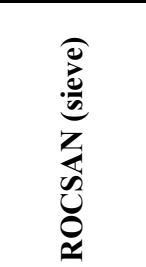 } & \multicolumn{3}{|c|}{ Geophysical Logs } & \multirow[b]{2}{*}{ 产 } & \multirow[b]{2}{*}{ 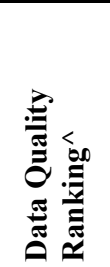 } & \multirow[b]{2}{*}{ 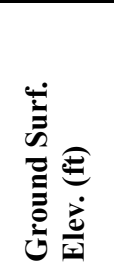 } & \multirow[b]{2}{*}{ 总 } & \multirow[b]{2}{*}{ 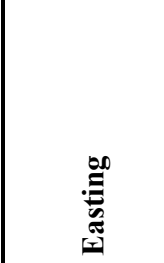 } \\
\hline & & & & & & & & & & & & & 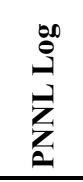 & 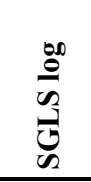 & 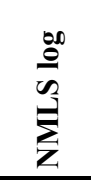 & & & & & \\
\hline 299-E33-340 & "G" Well & C5853 & 325.7 & $\mathrm{CT} / \mathrm{AR}$ & 2008 & $308.2-323.2$ & $\begin{array}{ll}\text { RRI } \\
\end{array}$ & No & Yes & No & Yes & No & & Yes & Yes & $\begin{array}{c}\text { Lab char., } \\
\text { hi-res photos }\end{array}$ & 1 & 617.9 & 137766.194 & 573779.325 \\
\hline 299-E33-341 & "D" well & C5856 & 237 & $\mathrm{DB} / \mathrm{SS}$ & 2008 & $223-233$ & CCUg & No & & No & Yes & No & No & Yes & Yes & $\begin{array}{c}\text { Photos, lab } \\
\text { logs }\end{array}$ & 1 & 627.5 & 137652.5 & 573565.21 \\
\hline 299-E33-342 & "E" well & C5857 & 245.5 & DB & 2008 & $232.6-242.6$ & CCUg & No & & No & Yes & No & No & Yes & Yes & $\begin{array}{c}\text { Photos, lab } \\
\text { logs }\end{array}$ & 1 & 636.9 & 137579.96 & 573625.68 \\
\hline 299-E33-343 & "A" well & C5858 & 263.8 & DB & 2008 & $250-260$ & CCUg & No & & No & Yes & No & No & Yes & Yes & $\begin{array}{c}\text { Photos, lab } \\
\text { logs }\end{array}$ & 1 & 652.3 & 137382.25 & 573743.98 \\
\hline 299-E33-345 & "Br" well & C6226 & 263.8 & DB & 2008 & $249.7-259.7$ & CCUg & No & & No & Yes & No & No & Yes & Yes & $\begin{array}{c}\text { Photos, lab } \\
\text { logs }\end{array}$ & 1 & 653.2 & 137388.24 & 573780.87 \\
\hline 299-E34-2 & & A4877 & 241.5 & HT & 1987 & $222-242$ & CCUg & No & & No & Yes & Yes & Yes & No & No & & 2 & 632.6 & 137220.694 & 574634.81 \\
\hline 299-E34-5 & & A 4880 & 190.5 & HT & 1987 & $170-190$ & CCUg & Yes & & No & Yes & Yes & Yes & No & No & & 2 & 592.6 & 137743.332 & 574643.809 \\
\hline 299-E34-7 & & A4882 & 205.5 & $\mathrm{HT} / \mathrm{DB}$ & 1989 & 194-204 & CCUg? & Yes & & Yes & Yes & No & Yes & No & No & & 3 & 604.7 & 137357.745 & 575274.184 \\
\hline 299-E34-9 & & A4884 & 234.5 & BH/DB & 1991 & $212-232$ & CCUg? & Yes & & No & Yes & No & Yes & No & No & $\begin{array}{l}\mathrm{CaCo}_{3} \text {, } \\
\text { moisture }\end{array}$ & 2 & 629.3 & 137429.82 & 574186.02 \\
\hline 299-E34-11 & & A4876 & 219.3 & DB & 1991 & $207.5-2117.5$ & CCUg & Yes & & No & Yes & No & Yes & No & No & $\begin{array}{l}\mathrm{CaCo}_{3} \text {, } \\
\text { moisture }\end{array}$ & 2 & 618.1 & 137581.78 & 574176.16 \\
\hline 299-E35-1 & & A4885 & 193.8 & $\mathrm{DB} / \mathrm{HT}$ & 1989 & 181-192 & H1 & Yes & & Yes & Yes & $0-80^{\prime}$ & Yes & No & No & & 2 & 598.8 & 137464.956 & 575459.729 \\
\hline 299-W11-88 & & C5572 & 490.2 & Sonic/rotary & 2008 & $445-485$ & & No & & No & Yes & No & No & Yes & No & & 1 & 725.5 & 137113.09 & 567874.67 \\
\hline 299-W12-1 & & A4912 & 314 & CT & 1956 & 274-309 (P) & & Yes & & Yes & No & Yes & No & No & No & & 4 & 727.6 & 137206.116 & 568331.248 \\
\hline 699-44-64 & & A5188 & 452 & $\mathrm{DB} / \mathrm{HT}$ & 1960 & $316-360(\mathrm{P})$ & & Yes & & Yes & No & Yes & No & No & No & & 3 & 726.7 & 136897.43 & 570390.65 \\
\hline 699-45-42 & $699-46-43$ & A5195 & 195 & $\mathrm{CT}$ & 1948 & $158-180$ & $?$ & Yes & & Yes & No & No & No & No & No & & 4 & 579.2 & 137286.372 & 577055.094 \\
\hline 699-45-69C & & C5574 & 455 & Rotary/sonic & 2007 & $367-382$ & Ringold & No & & No & Yes & No & No & Yes & No & & 2 & 727.3 & 137233.81 & 568947.12 \\
\hline 699-47-42 & BWIP DB-15 & A8749 & 1971 & $\mathrm{CT} / \mathrm{MR}$ & 1979 & None & N/A & Yes & & No & $\begin{array}{l}\text { Not for } \\
\text { post-basalt } \\
\text { sediments }\end{array}$ & No & & & & & 5 & 470.9 & 137909.026 & 577156.481 \\
\hline 699-47-46A & & A5200 & 207 & СT & 1961 & 168-181 & Hanford fm and basalt & & Yes & Yes & No & $10-200^{\prime}$ & No & No & No & & 3 & 581.7 & 137820.739 & 575869.826 \\
\hline 699-47-50 & & A5201 & 295 & СТ & 1980 & $260-295$ & RRI & No & & Yes & No & 265-295' & No & No & No & & 4 & 585.1 & 137887.166 & 574798.717 \\
\hline 699-47-51 & & A8752 & 167 & СT & 1959 & None & N/A & No & & Yes & No & $0-160^{\prime}$ & Yes & & & & 4 & 585.0 & 137953.171 & 574352.297 \\
\hline 699-47-60 & & A5202 & 287 & CT & 1948 & $250-287$ & Hanford/CCUg/CRB & Yes & Yes & Yes & No & $5-250^{\prime}$ & No & No & No & & 3 & 652.3 & 137968.732 & 571474.38 \\
\hline 699-48-48A & ARH-DC-1 & A8768 & 5661 & MR & 1972 & None & N/A & & No & No & No & No & & No & No & & 5 & 575.0 & 138112.7 & 575196.576 \\
\hline 699-48-48B & BWIP DC-2 & A8769 & 3374 & CT & 1977 & None & N/A & & No & Yes & Yes & No & & No & No & & 4 & 573.1 & 138104.005 & 575179.031 \\
\hline 699-48-49 & & A8770 & ? & $?$ & ? & ? & ? & No & No & No & No & No & No & No & No & & 5 & 572.5 & 138113.13 & 574951.895 \\
\hline 699-48-50 & & A5212 & 197 & $\mathrm{DB} / \mathrm{HT}$ & 1990 & $160-180$ & Hanford & No & No & No & Yes & No & Yes & No & No & & 2 & 574.6 & 138227.088 & 574817.584 \\
\hline 699-48-50B & & C5196 & 215.2 & DB & 2006 & 204.2-214.5 & Ringold/CRB & No & Yes & No & Yes & No & No & Yes & Yes & 138056.941 & 1 & 608.8 & 138044.28 & 573334.48 \\
\hline 699-48-71 & & A5214 & 305 & СT & 1956 & $239-302$ & Ringold & Yes & & Yes & No & Yes & No & No & No & & 4 & 690.3 & 138056.941 & 568387.914 \\
\hline 699-49-55A & & A5217 & 149 & $\mathrm{HT} / \mathrm{DB}$ & 1961 & 124-139 & Ringold/CRB & Yes & & Yes & No & No & No & No & No & & 4 & 531.8 & 138351.781 & 573146.301 \\
\hline
\end{tabular}


Table E.1. (contd)

\begin{tabular}{|c|c|c|c|c|c|c|c|c|c|c|c|c|c|c|c|c|c|c|c|c|}
\hline \multirow[b]{3}{*}{ Well Name } & \multicolumn{17}{|c|}{ Available Data } & \multicolumn{3}{|c|}{ Survey Data } \\
\hline & \multirow[b]{2}{*}{ 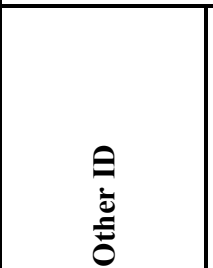 } & \multirow[b]{2}{*}{ 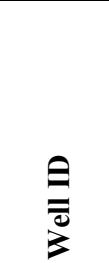 } & \multirow[b]{2}{*}{ 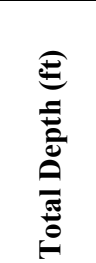 } & \multirow[b]{2}{*}{ 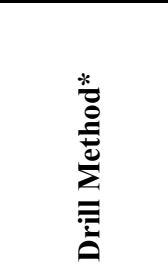 } & \multirow[b]{2}{*}{ 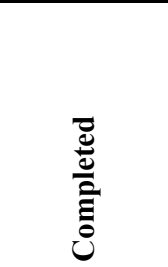 } & \multirow[b]{2}{*}{ 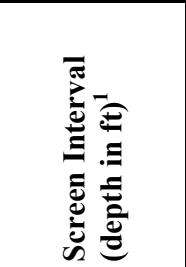 } & \multirow[b]{2}{*}{ 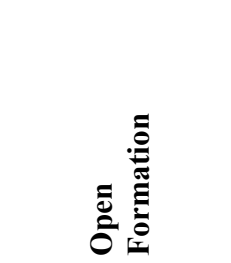 } & \multirow{2}{*}{ 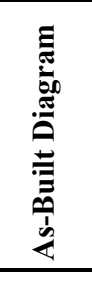 } & \multirow[b]{2}{*}{ 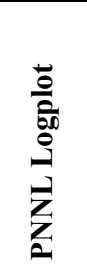 } & \multirow[b]{2}{*}{ 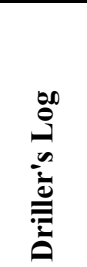 } & \multirow[b]{2}{*}{ 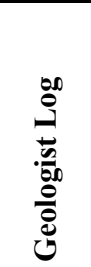 } & \multirow{2}{*}{ 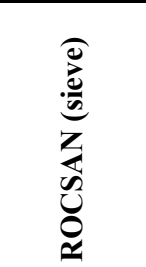 } & \multicolumn{3}{|c|}{ Geophysical Logs } & \multirow[b]{2}{*}{ 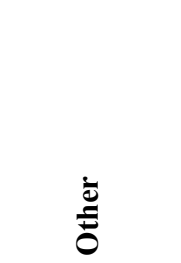 } & \multirow[b]{2}{*}{ 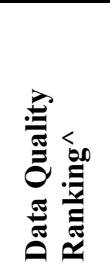 } & \multirow[b]{2}{*}{ 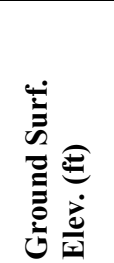 } & \multirow[b]{2}{*}{ 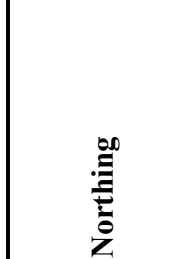 } & \multirow[b]{2}{*}{ 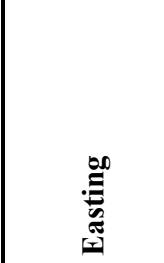 } \\
\hline & & & & & & & & & & & & & 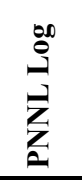 & 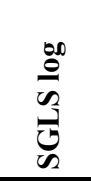 & 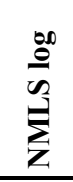 & & & & & \\
\hline 699-49-55B & & A5218 & 227 & $\mathrm{CT} / \mathrm{AR}$ & 1982 & $175-226$ & CRB/RRI & Yes & Yes & Yes & No & No & No & No & No & & 4 & 531.8 & 138350.879 & 573138.718 \\
\hline 699-49-57A & & A5219 & 168 & $\mathrm{HT} / \mathrm{AR}$ & 1956 & 144-161 (P) & CCUg & Yes & & Yes & No & $5-168^{\prime}$ & & No & No & & 3 & 554.3 & 138389.24 & 572544.276 \\
\hline 699-49-57B & & A5220 & 230.4 & $\mathrm{DB} / \mathrm{HT}$ & 1990 & $220-230$ & RRI & No & Yes & No & Yes & & Yes & No & No & & 2 & 556.5 & 138381.034 & 572536.452 \\
\hline 699-49-71 & & A9918 & 30 & DB & 1993 & None & $\mathrm{N} / \mathrm{A}$ & No & & Yes & No & & & No & No & & 5 & & 138223 & 568580 \\
\hline 699-50-42 & & A5224 & 125 & СТ & 1955 & $\begin{array}{l}\text { 53-64 (P); } \\
\text { 110-115' }\end{array}$ & Ringold;CRB & Yes & & Yes & No & $5-65^{\prime}$ & No & No & No & & 3 & 468.4 & 138786.691 & 577111.013 \\
\hline 699-50-45 & & A5225 & 178 & $\mathrm{CT} / \mathrm{AR}$ & 1980 & 133-178 & RRI & Yes & & Yes & No & $\begin{array}{c}\text { 135-175' } \\
\text { (RRI) }\end{array}$ & No & No & No & & 3 & 452.6 & 138783.367 & 576172.755 \\
\hline 699-50-48A & BWIP DDH-1 & A8812 & 1,165 & $\mathrm{CT} / \mathrm{RC}$ & 1955/1969 & None & N/A & Yes & Yes & Yes & No & $5-170^{\prime}$ & No & No & No & & 3 & 553.4 & 138684.761 & 575154.969 \\
\hline 699-50-48B & & A5226 & 250 & $\mathrm{CT} / \mathrm{AR}$ & 1980 & $210-250$ & RRI & Yes & & Yes & No & $\begin{array}{c}225-250^{\prime} \\
\text { (RRI) }\end{array}$ & No & No & No & & 3 & 552.0 & 138715.913 & 575390.732 \\
\hline 699-50-53A & & A5227 & 185 & CT & 1955 & $142-159$ & Hanford & Yes & & Yes & No & $5-185^{\prime}$ & No & No & No & & 3 & 558.3 & 138670.477 & 573649.666 \\
\hline 699-50-53B & & A5228 & 225 & $\mathrm{DB} / \mathrm{SS}$ & 1990 & $215-225$ & RRI & No & & No & Yes & & Yes & No & No & & 2 & 558.4 & 138659.519 & 573655.45 \\
\hline 699-50-56 & & C5197 & 164.1 & DB & 2006 & $151-161$ & Ringold & No & Yes & No & Yes & No & No & Yes & Yes & $\begin{array}{l}\text { Photos, core } \\
\log \end{array}$ & 1 & 551.8 & 138841.55 & 572748.21 \\
\hline 699-50-59 & & C4882 & 173.2 & $\mathrm{BH}$ & 2005 & $163-168$ & Hanford & No & Yes & No & Yes & No & No & No & No & Core log & 2 & 564.6 & 138741.72 & 571946.9 \\
\hline 699-50-74 & & C4697 & 338.8 & $\mathrm{BH}$ & 2005 & ? & $?$ & No & & No & Yes & No & No & Yes & No & & 2 & 658.3 & 138646.73 & 567359.52 \\
\hline 699-51-46 & 699-51-47 & A 5230 & 168 & AR/HT & 1980 & $113-163$ & RRI & Yes & & Yes & No & $\begin{array}{c}125-165^{\prime} \\
\text { (RRI) }\end{array}$ & No & No & No & & 4 & 446.0 & 139001.588 & 575738.496 \\
\hline 699-51-63 & & A5231 & 184.5 & CT & 1956 & $157-183$ & Hanford & Yes & & Yes & No & $5-185$ & No & No & No & & 3 & 573.4 & 139148.408 & 570664.4 \\
\hline 699-52-46A & & A5234 & 225 & $\mathrm{CT} / \mathrm{AR}$ & 1980 & $175-225$ & RRI & Yes & Yes & Yes & No & $\begin{array}{c}\text { 175-225' } \\
\text { (RRI) }\end{array}$ & No & No & No & & 3 & 457.2 & 139358.005 & 575903.296 \\
\hline 699-52-46B & & A8841 & 44 & CT & 1980 & $39-44$ & Hanford? & Yes & & Yes & No & No & No & No & No & & 4 & $?$ & 139395 & 575952.5 \\
\hline 699-52-48 & & A5235 & 197 & $\mathrm{CT} / \mathrm{AR}$ & 1980 & 153-195 & RRI & Yes & & Yes & No & $\begin{array}{l}155-190^{\prime} \\
\text { (RRI) }\end{array}$ & No & No & No & & 3 & 468.6 & 139195.665 & 575231.474 \\
\hline 699-52-52 & BWIP DB-5 & A8842 & 903 & AR/RC & 1974 & None & N/A & Yes & & Yes & Yes & $5-145^{\prime}$ & No & No & No & & 3 & 560.8 & 139293.862 & 573920.523 \\
\hline 699-52-54 & & A5236 & 168.6 & $\mathrm{DB} / \mathrm{HT} / \mathrm{SS}$ & 1990 & $156-166$ & Hanford & No & & No & Yes & No & Yes & No & No & & 2 & 568.9 & 139193.172 & 573254.242 \\
\hline 699-52-55 & $\begin{array}{l}\text { 699-52-55A; } \\
\text { "N" well }\end{array}$ & C5861 & 183.3 & DB & 2007 & $170-180$ & CCUg & No & Yes & No & Yes & No & No & Yes & yes & Photos & 1 & 574 & 139443.2 & 573102.44 \\
\hline 699-52-55B & "H" well & C5862 & 292 & DB & 2008 & $228.5-243.5$ & RRI & No & Yes & No & Yes & No & No & Yes & Yes & $\begin{array}{l}\text { Core log } \\
\text { (RRI) }\end{array}$ & 1 & 573.7 & 139440.66 & 573102.17 \\
\hline 699-52-57 & $699-51-56$ & A5237 & 165.5 & $\mathrm{DB} / \mathrm{SS} / \mathrm{HT}$ & 1991 & $149-159$ & CCUg & Yes & Yes & No & Yes & No & Yes & No & No & & 2 & 561.7 & 139115.316 & 572761.346 \\
\hline 699-53-47A & & A5239 & 41.5 & $\mathrm{DB} / \mathrm{HT}$ & 1966 & $22-33$ & Hanford & Yes & & Yes & No & No & No & No & No & & 4 & 439.2 & 139489.296 & 575417.545 \\
\hline 699-53-48A & & A5241 & 53 & $\mathrm{DB} / \mathrm{HT}$ & 1984 & None & $\mathrm{N} / \mathrm{A}$ & Yes & & Yes & No & No & No & No & No & & 4 & 443.4 & 139593.885 & 575338.712 \\
\hline 699-53-48B & & A5242 & 44 & CT & 1984 & $24-44$ & Hanford/CCUz & Yes & & Yes & No & No & No & No & No & & 4 & 443.6 & 139595.705 & 575336.306 \\
\hline 699-53-50 & & A5243 & 194 & HT/AR & 1980 & 144-194 & RRI & Yes & & Yes & No & $\begin{array}{c}\text { 160-190' } \\
\text { (RRI) }\end{array}$ & Yes & No & No & & 3 & 445.8 & 139700.592 & 574584.129 \\
\hline 699-53-55A & & A5244 & 455 & CT & 1961 & $165-280(\mathrm{P})$ & Hanford/RRI & Yes & & Yes & No & No & No & No & No & & 4 & 577.3 & 139631.884 & 573115.859 \\
\hline
\end{tabular}


Table E.1. (contd)

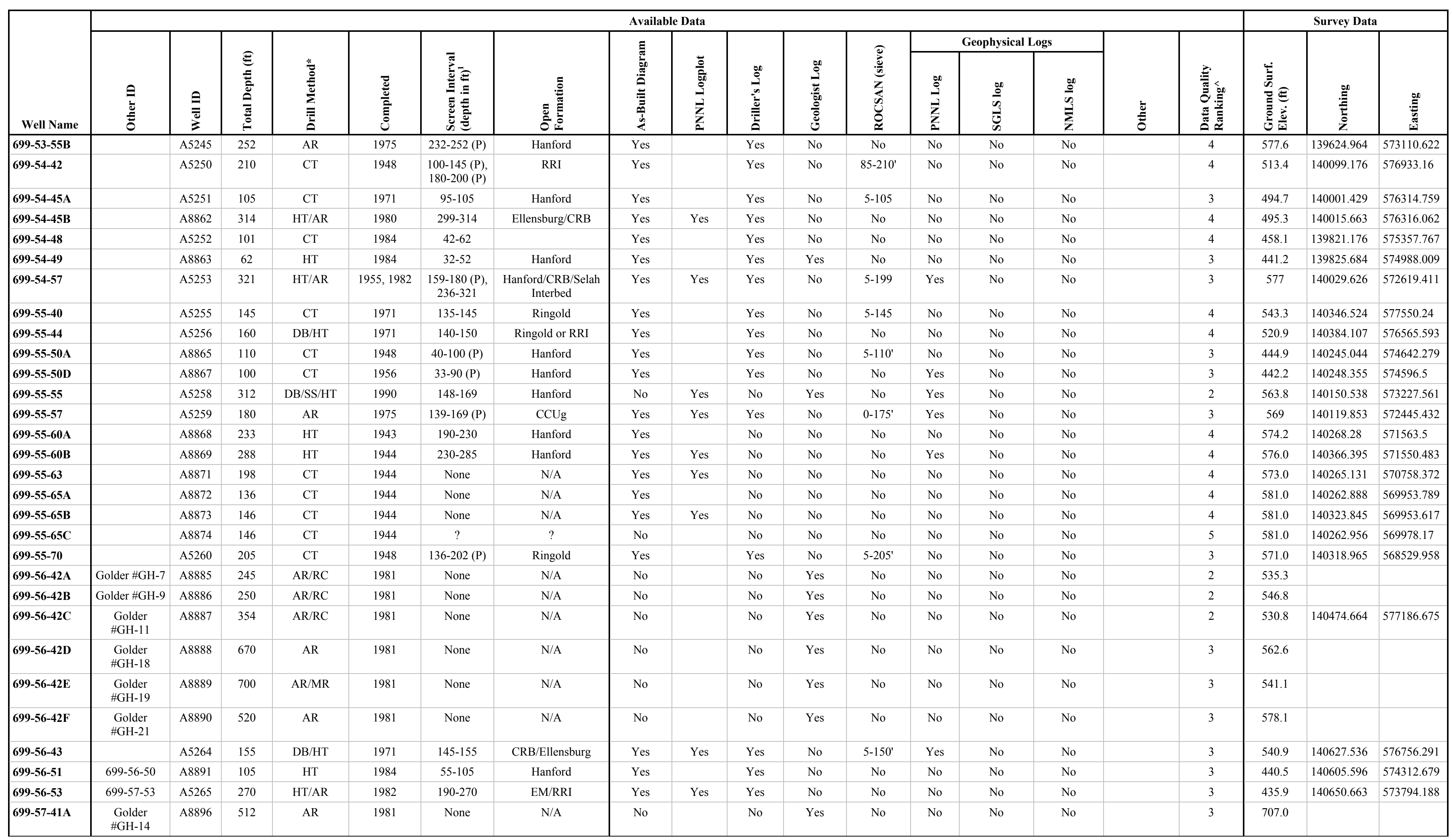


Table E.1. (contd)

\begin{tabular}{|c|c|c|c|c|c|c|c|c|c|c|c|c|c|c|c|c|c|c|c|c|}
\hline \multirow[b]{3}{*}{ Well Name } & \multicolumn{17}{|c|}{ Available Data } & \multicolumn{3}{|c|}{ Survey Data } \\
\hline & \multirow[b]{2}{*}{$\begin{array}{l}\text { 离 } \\
\text { ప̃ }\end{array}$} & \multirow[b]{2}{*}{ 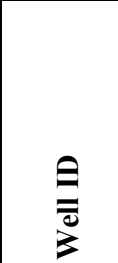 } & \multirow[b]{2}{*}{ 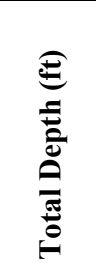 } & \multirow[b]{2}{*}{ 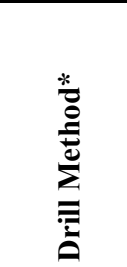 } & \multirow[b]{2}{*}{ 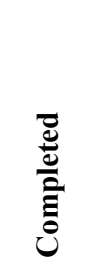 } & \multirow[b]{2}{*}{ 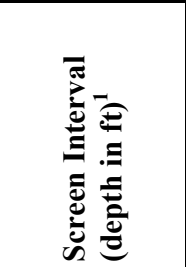 } & \multirow[b]{2}{*}{ 咅 } & \multirow{2}{*}{ 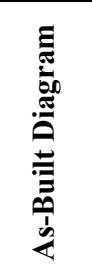 } & \multirow[b]{2}{*}{ 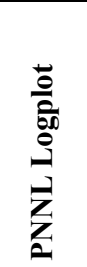 } & \multirow[b]{2}{*}{ 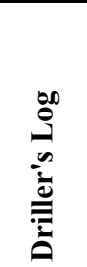 } & \multirow[b]{2}{*}{ 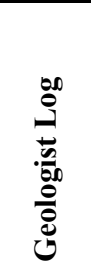 } & \multirow{2}{*}{ 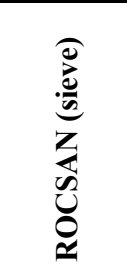 } & \multicolumn{3}{|c|}{ Geophysical Logs } & \multirow[b]{2}{*}{ 产 } & \multirow[b]{2}{*}{ 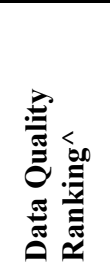 } & \multirow[b]{2}{*}{ 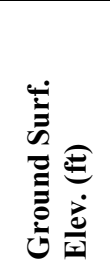 } & \multirow[b]{2}{*}{ 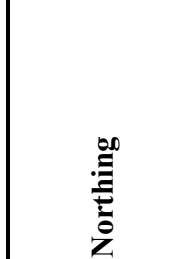 } & \multirow[b]{2}{*}{ 昜 } \\
\hline & & & & & & & & & & & & & 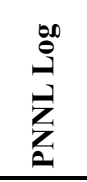 & 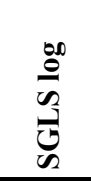 & 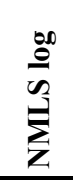 & & & & & \\
\hline $\begin{array}{l}699-57-41 B \\
\end{array}$ & $\begin{array}{l}\text { Golder } \\
\# \text { GH-15 }\end{array}$ & A8897 & 461 & $\overline{A R}$ & 1981 & None & N/A & No & & No & Yes & No & No & No & No & & 3 & 710.6 & & \\
\hline 699-57-41C & $\begin{array}{l}\text { Golder } \\
\text { \#GH-16 }\end{array}$ & A 8898 & 430 & $\mathrm{AR}$ & 1981 & None & $\mathrm{N} / \mathrm{A}$ & No & & No & Yes & No & No & No & No & & 3 & 709.3 & & \\
\hline 699-57-41E & $\begin{array}{c}\text { Golder } \\
\# \text { GH-22 }\end{array}$ & A8900 & 554 & AR & 1981 & None & N/A & No & & No & Yes & No & No & No & No & & 3 & 698.4 & & \\
\hline 699-57-41F & $\begin{array}{l}\text { Golder } \\
\# \text { GH-23 }\end{array}$ & A8901 & 608 & $\mathrm{AR} / \mathrm{RC}$ & 1981 & None & $\mathrm{N} / \mathrm{A}$ & No & & No & Yes & No & No & No & No & & 2 & 707.6 & 140986.334 & 577362.842 \\
\hline 699-57-59 & & A5269 & 190.5 & DB & 1980 & $166-186$ & CCUg or Ringold & No & Yes & Yes & Yes & $0-188^{\prime}$ & Yes & No & No & & 2 & 576.6 & 140923.719 & 571830.216 \\
\hline 699-58-41A & Golder \#GH-1 & A8908 & 274 & $\mathrm{AR} / \mathrm{RC}$ & 1980 & None & N/A & No & & No & Yes & No & No & No & No & & 2 & 709.9 & & \\
\hline 699-58-41B & Golder \#GH-2 & A8909 & 225 & $\mathrm{AR} / \mathrm{RC}$ & 1980 & None & N/A & No & & No & Yes & No & No & No & No & & 2 & 704.0 & & \\
\hline 699-58-41C & Golder \#GH-3 & A8910 & 130 & AR & 1980 & None & N/A & No & & No & Yes & No & No & No & No & & 3 & 702.9 & & \\
\hline 699-58-41D & Golder \#GH-4 & A8911 & 79 & $\mathrm{AR} / \mathrm{RC}$ & 1980 & None & N/A & No & & No & Yes & No & No & No & No & & 2 & 701.8 & & \\
\hline 699-58-41E & $\begin{array}{l}\text { Golder } \\
\text { \#GH-13 }\end{array}$ & A8912 & 390 & $\mathrm{AR}$ & 1981 & None & $\mathrm{N} / \mathrm{A}$ & No & & No & Yes & No & No & No & No & & 3 & 700.4 & 141188.31 & 577473.22 \\
\hline 699-58-41F & $\begin{array}{c}\text { Golder } \\
\# \text { GH-20 }\end{array}$ & A8913 & 600 & AR/MR & 1981 & None & $\mathrm{N} / \mathrm{A}$ & No & & No & Yes & No & No & No & No & & 3 & 699.5 & 141051.482 & 577435.757 \\
\hline 699-58-48 & & A8914 & $?$ & $?$ & ? & ? & $?$ & No & & No & No & No & No & No & No & & 5 & $?$ & 141153.4 & 575262.6 \\
\hline 699-59-55 & BWIP DH-10 & A8918 & 145 & AR & 1976 & None & N/A & Yes & & No & No & No & No & No & No & & 5 & 432.2 & 141544.108 & 573049.268 \\
\hline 699-59-58 & GBM-8 & A5277 & 117 & СТ & 1972 & $85-105$ & Hanford & Yes & Yes & Yes & No & $60-110^{\prime}$ & Yes & No & No & & 3 & 498.8 & 141414.963 & 572273.618 \\
\hline 699-60-53B & CH-2 & A8922 & 160 & $\mathrm{RC}$ & 1980 & None & N/A & Yes & & No & No & No & No & No & No & & 5 & ? & 141766.917 & 573722.707 \\
\hline 699-60-53C & $\mathrm{CH}-3$ & A8923 & 150 & $\mathrm{RC}$ & 1980 & None & $\mathrm{N} / \mathrm{A}$ & Yes & & No & No & No & No & No & No & & 5 & ? & & \\
\hline 699-60-53F & CH-6 & A8926 & 290 & $\mathrm{RC}$ & 1980 & None & N/A & Yes & & No & No & No & No & No & No & & 5 & 821.0 & & \\
\hline 699-60-57 & & A5280 & 155 & HT & 1972 & $\begin{array}{l}60-70 \\
127-147\end{array}$ & $\begin{array}{c}\text { Hanford, } \\
\text { Hanford/Ringold }\end{array}$ & Yes & Yes & Yes & No & $40-143^{\prime}$ & Yes & No & No & & 3 & 470.6 & 141870.325 & 572623.495 \\
\hline 699-60-59 & BWIP DC-18 & A5281 & 1561 & $\mathrm{CT} / \mathrm{RC}$ & 1986 & None & $\mathrm{N} / \mathrm{A}$ & Yes & & Yes & Yes & No & Yes & No & No & & 2 & 509.2 & 141854.447 & 572038.132 \\
\hline 699-60-60 & & A5282 & 133 & CT & 1948 & 100-127 (P) & Hanford & Yes & Yes & Yes & No & No & No & No & No & & 4 & 513 & 141763.907 & 571588.581 \\
\hline 699-61-53 & BWIP DC-11 & A8932 & 385 & $\mathrm{RC}$ & 1978 & None & N/A & Yes & & No & Yes & No & No & No & No & & 3 & 764.8 & 141978.102 & 573714.117 \\
\hline 699-61-55A & BWIP DH-8A & A8933 & 249 & $\mathrm{RC}$ & 1976 & None & N/A & Yes & & No & Yes & No & No & No & No & & 3 & 463.0 & 141983.739 & 573009.153 \\
\hline 699-61-55B & BWIP DH-8B & A8934 & 327 & $\mathrm{AR} / \mathrm{CT}$ & 1976 & None & N/A & No & & No & No & No & No & No & No & & 5 & 464.1 & & \\
\hline 699-61-57 & BWIP DB-9 & A8935 & 589 & $\mathrm{RC}$ & 1977 & $490-589$ & Mabton & Yes & & No & Yes & No & No & No & No & & 3 & 444 & 142435.066 & 572608.219 \\
\hline 699-61-62 & GBM-1 & A5285 & 188 & $\mathrm{DB} / \mathrm{HT}$ & 1972 & 86-100 (P) & Hanford & Yes & Yes & Yes & Yes & No & Yes & No & No & & 2 & 497.9 & 141921.659 & 570914.859 \\
\hline 699-61-66 & & A5286 & 225 & СT & 1955 & $105-160$ & Hanford/Ringold & Yes & Yes & Yes & No & $5-225^{\prime}$ & Yes & No & No & & 3 & 523.9 & 142007.963 & 569787.591 \\
\hline 699-62-43B & & A8940 & 68 & СT & 1959 & 3-50 (P) & Hanford & Yes & & Yes & No & No & Yes & No & No & & 3 & 422.4 & 142488.248 & 576805.215 \\
\hline 699-62-53 & BWIP DC-10 & A8953 & 456 & $\mathrm{RC}$ & 1977 & None & $\mathrm{N} / \mathrm{A}$ & No & & No & Yes & No & No & No & No & & 3 & 439.4 & 142518.932 & 573646.175 \\
\hline 699-63-51 & GM-17 & A5290 & 36 & СT & 1971 & 18-31 (P) & Hanford/Ringold & Yes & & Yes & No & $5-35^{\prime}$ & No & No & No & & 3 & 425.4 & 142553.674 & 574446.762 \\
\hline 699-63-55 & & A5291 & 121 & $\mathrm{DB} / \mathrm{HT}$ & 1972 & 23-65 (P) & Hanford & Yes & & Yes & No & Yes & No & No & No & & 3 & 427.1 & 142562.319 & 573094.386 \\
\hline
\end{tabular}


Table E.1. (contd)

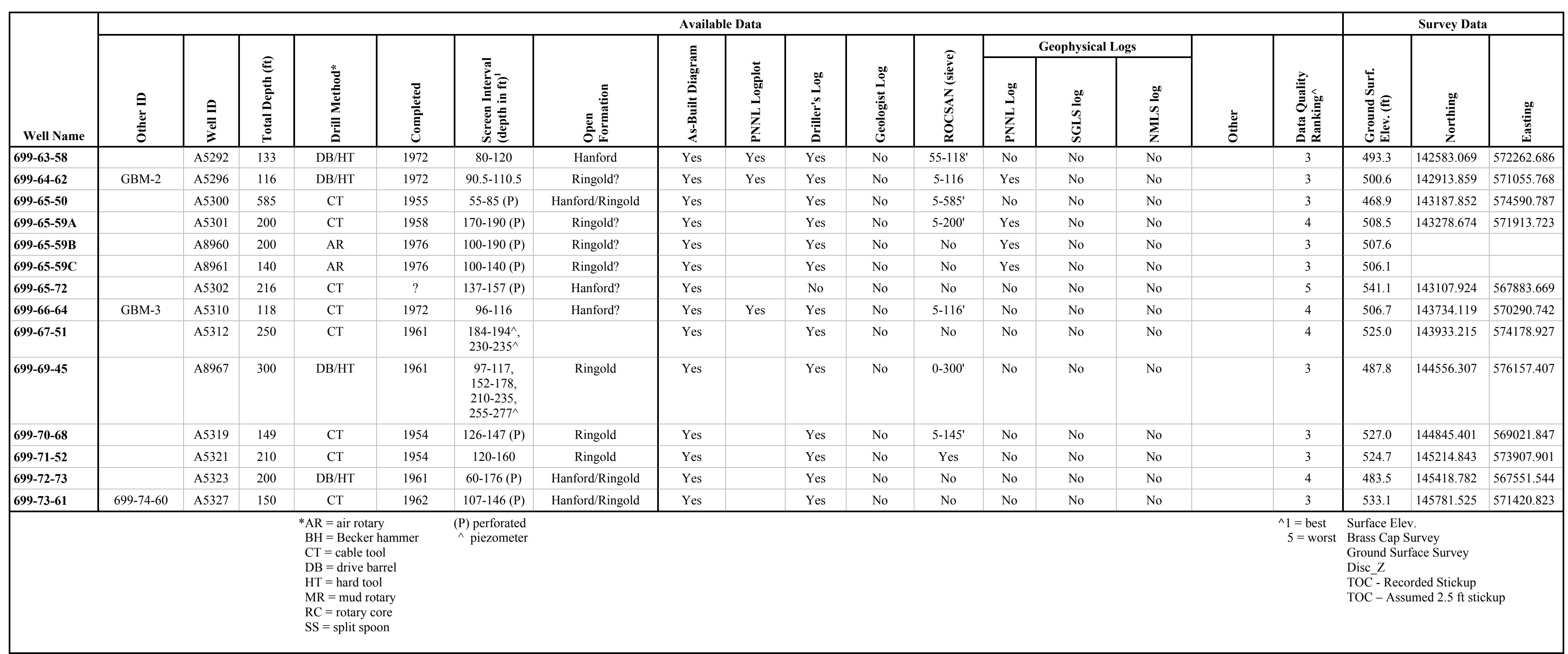


Table E.1. (contd)

\begin{tabular}{|c|c|c|c|c|c|c|c|c|c|c|c|c|c|c|c|c|c|c|c|c|c|c|c|c|c|c|c|c|c|c|c|c|}
\hline \multirow[b]{2}{*}{ Well Name } & \multicolumn{11}{|c|}{ Contact Depths (ft) } & \multicolumn{9}{|c|}{ Contact Elevations (ft) } & \multicolumn{11}{|c|}{ Thickness (ft) } & \multirow[b]{2}{*}{ Comments } \\
\hline & $\frac{\mathscr{g}}{\bar{\Xi}}$ & $\begin{array}{l}E \\
\vdots \\
0\end{array}$ & 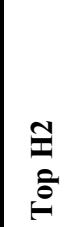 & $\begin{array}{l}3 \\
3 \\
0 \\
0\end{array}$ & 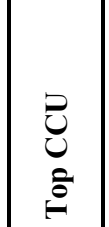 & 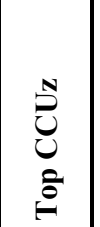 & $\begin{array}{l}\underbrace{\infty}_{0} \\
0 \\
0 \\
0 \\
0\end{array}$ & 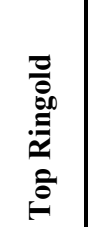 & $\stackrel{\infty}{0}$ & 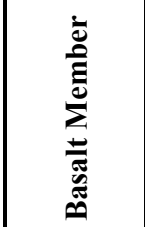 & 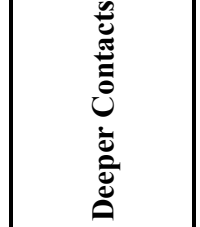 & 产 & 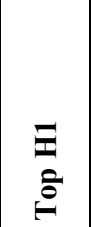 & 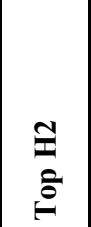 & 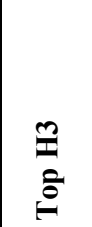 & 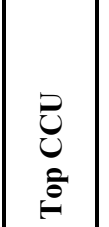 & 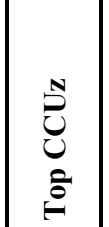 & 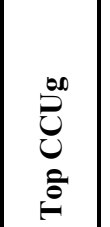 & 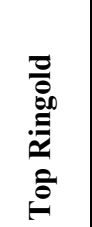 & $\stackrel{0}{0}$ & 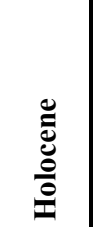 & 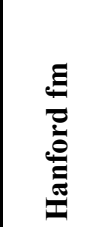 & $\Xi$ & $\Xi$ & $\cong$ & 己 & 己ृ & $\overbrace{0}^{\infty}$ & 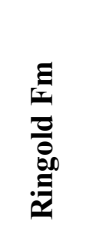 & 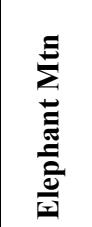 & 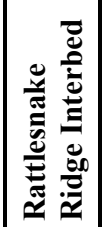 & \\
\hline \begin{tabular}{|l|} 
299-E26-77 \\
\end{tabular} & 0 & 3 & $\mathrm{NP}$ & & $178 ?$ & $\mathrm{NP}$ & $178 ?$ & NP & 205.5 & & & 603 & 600 & $\mathrm{NP}$ & & $425 ?$ & $\mathrm{NP}$ & $425 ?$ & $\mathrm{NP}$ & 397.7 & 3 & $175 ?$ & $175 ?$ & $\mathrm{NP}$ & $\mathrm{NP}$ & 27 & 0 & 27 & $\mathrm{NP}$ & & & $\begin{array}{l}\text { Geophys. Anomaly from 178-183= } \\
\text { top of CCUg? }\end{array}$ \\
\hline 299-E26-79 & 0 & 1 & NP & NP & 163 & NP & 163 & NP & 207 & & & 597 & 597 & NP & & $435 ?$ & NP & $435 ?$ & NP & 391 & 1 & 162 & 162 & NP & $\mathrm{NP}$ & $44 ?$ & 0 & $44 ?$ & $\mathrm{NP}$ & & & \\
\hline 299-E27-16 & NP & 0 & 37 & NP & 205 & NP & 205 & NP & 269 & & & $\mathrm{NP}$ & 653 & 616 & $\mathrm{NP}$ & 448 & NP & 448 & NP & 383.8 & 0 & 205 & 37 & 168 & NP & 64 & $\mathrm{NP}$ & 64 & $\mathrm{NP}$ & & & \\
\hline 299-E28-26 & NP & 0 & 70 & 225 & ? & NP & ? & NP & 326 & & & $\mathrm{NP}$ & 688 & 618 & 463 & ? & $\mathrm{NP}$ & ? & NP & 362.4 & 0 & ? & 70 & 155 & $?$ & ? & $\mathrm{NP}$ & ? & $\mathrm{NP}$ & & & \\
\hline 299-E28-28 & NP & 0 & 70 & 205 & $255 ?$ & NP & $255 ?$ & $?$ & ETD & & & $\mathrm{NP}$ & 687 & 617 & 482 & $432 ?$ & NP & $432 ?$ & $?$ & ETD & 0 & $255 ?$ & 70 & 135 & $50 ?$ & $>41$ & $\mathrm{NP}$ & $>41$ & $?$ & & & \\
\hline 299-E32-2 & NP & 0 & 55 & 210 & NP & & & NP & 287 & & & $\mathrm{NP}$ & 672 & 617 & 466 & ? & NP & $?$ & NP & 384.5 & 0 & ? & 55 & 150 & $?$ & ? & $\mathrm{NP}$ & ? & NP & & & \\
\hline 299-E32-3 & NP & 0 & 60 & 195 & $?$ & NP & $?$ & 293 & ETD & & & NP & 679 & 619 & 484 & $?$ & NP & $?$ & 386 & ETD & 0 & ? & 60 & 135 & $?$ & $?$ & $\mathrm{NP}$ & ? & $>11$ & & & \\
\hline 299-E32-4 & 0 & 5 & 65 & 200 & $?$ & NP & ? & 297 & ETD & & & 688 & 683 & 623 & 488 & $?$ & NP & ? & 391 & ETD & 5 & ? & 60 & 135 & $?$ & $?$ & $\mathrm{NP}$ & ? & $>14$ & & & $>264 \mathrm{~m} /$ day constant rate aquifer test \\
\hline 299-E32-5 & NP & 0 & 60 & 203 & $?$ & & & ? & ETD & & & $\mathrm{NP}$ & 683 & 623 & 480 & ? & & ? & $?$ & ETD & 0 & ? & 60 & 143 & $?$ & ? & & ? & ? & & & $175 \mathrm{~m} /$ day slug test \\
\hline 299-E32-6 & NP & 0 & 55 & 210 & $?$ & NP & $?$ & $?$ & ETD & & & $\mathrm{NP}$ & 667 & 612 & 457 & $?$ & $\mathrm{NP}$ & $?$ & $?$ & ETD & 0 & ? & 55 & 155 & $?$ & $?$ & $\mathrm{NP}$ & ? & $?$ & & & \\
\hline 299-E32-7 & NP & 0 & 60 & 190 & $?$ & NP & $?$ & 270 & ETD & & & $\mathrm{NP}$ & 658 & 598 & 468 & $?$ & NP & $?$ & 388 & ETD & 0 & $>274$ & 60 & 130 & $?$ & $?$ & $\mathrm{NP}$ & ? & ? & & & \\
\hline 299-E32-8 & NP & 0 & 20 & 166 & $?$ & & $?$ & $?$ & ETD & & & NP & 645 & 625 & 479 & $?$ & & $?$ & $?$ & ETD & 0 & $?$ & 20 & 146 & $?$ & $?$ & & $?$ & $?$ & & & \\
\hline 299-E32-9 & NP & 0 & 39 & 180 & $?$ & NP & $?$ & $?$ & ETD & & & $\mathrm{NP}$ & 643 & 604 & 463 & $?$ & $\mathrm{NP}$ & $?$ & $?$ & ETD & 0 & ? & 39 & 141 & $?$ & $?$ & $\mathrm{NP}$ & ? & $?$ & & & \\
\hline 299-E33-29 & NP & 0 & 55 & 214 & 233 & 233 & 234 & & 290 & & & $\mathrm{NP}$ & 675 & 620 & 461 & 442 & 442 & 441 & NP & 385.0 & 0 & 233 & 55 & 159 & 19 & 57 & 1 & 56 & $\mathrm{NP}$ & & & $\begin{array}{l}*>1400 \mathrm{~m} / \mathrm{d} \text { constant-rate aquifer } \\
\text { test }=\text { discrepancy }\end{array}$ \\
\hline 299-E33-30 & NP & 0 & 56 & 202 & 224 & 224 & 227 & NP & 277 & & & $\mathrm{NP}$ & 666 & 610 & 463 & 441.5 & 441.5 & 438.5 & NP & 388.5 & 0 & 225 & 56 & 147 & 21 & 53 & 3 & 50 & NP & & & \\
\hline 299-E33-33 & NP & 0 & 37 & & 202 & 202 & 216 & NP & 252 & & & $\mathrm{NP}$ & 641 & 604 & & 439 & 439 & 425 & NP & 389 & 0 & 202 & 37 & 165 & NP & 50 & 14 & 36 & NP & & & \\
\hline 299-E33-34 & NP & 0 & 20 & NP & 195 & 195 & 200 & NP & 240 & & & $\mathrm{NP}$ & 634 & 614 & $\mathrm{NP}$ & 439 & 439 & 434 & NP & 394 & 0 & 195 & 20 & 175 & $\mathrm{NP}$ & 45 & 5 & 40 & 0 & & & \\
\hline 299-E33-35 & NP & 0 & 10 & NP & 200 & 200 & 205 & NP & 250 & & & $\mathrm{NP}$ & 644 & 634 & NP & 444 & 444 & 439 & NP & 394 & 0 & 200 & 10 & 190 & NP & 50 & 5 & 45 & 0 & & & \\
\hline 299-E33-36 & NP & 0 & 30 & NP & 203 & 203 & 205 & NP & 263.8 & & & NP & 647 & 617 & NP & 444 & 444 & 442 & NP & 383.4 & 0 & 203 & 30 & 173 & NP & 61 & 2 & 59 & NP & & & \\
\hline 299-E33-45 & 0 & NP & 40 & NP & 218 & 218 & 239 & NP? & ETD & & & 657 & NP & 617 & $\mathrm{NP}$ & 439 & 439 & 418 & NP? & ETD & 40 & 178 & NP & 178 & NP & $>43$ & 20 & $>23$ & NP? & & & $40^{\prime}$ backfill at surface \\
\hline 299-E33-46 & 0 & NP & 38.5 & NP & 215 & 215 & 228 & NP? & ETD & & & 657 & NP & 619 & NP & 442 & 442 & 429 & NP? & ETD & 38.5 & 177 & NP & 177 & NP & $>49$ & 13 & $>36$ & NP? & & & $38 \mathrm{ft}$ of backfill at surface \\
\hline 299-E33-49 & 0 & 45 & 49 & $\mathrm{NP}$ & 217 & 217 & 218 & NP & 283.5 & & & 667 & 622 & 618 & $\mathrm{NP}$ & 450 & 450 & 449 & $\mathrm{NP}$ & 383.5 & 45 & 172 & 4 & 168 & $\mathrm{NP}$ & 66.5 & 1 & 65.5 & $\mathrm{NP}$ & & & Holocene $=45^{\prime}$ backfill \\
\hline 299-E33-50 & 0 & 2 & 11 & NP & 149 & 149 & 187.5 & NP & 233.6 & $\begin{array}{l}\text { Elephant } \\
\text { Mtn }\end{array}$ & $\begin{array}{l}\text { RRI }=316.5, \\
\text { Pomona }= \\
375.5\end{array}$ & 626 & 624 & 615 & NP & 477 & 477 & 438.5 & NP & 392 & 2 & 147 & 9 & 138 & NP & 85 & 38.5 & 46 & $\mathrm{NP}$ & 83 & 59 & \\
\hline 299-E33-205 & 0 & 2 & 31 & NP & 221 & 221 & 238 & NP & 267 & $\begin{array}{c}\text { Elephant } \\
\text { Mtn }\end{array}$ & & 657 & 655 & 626 & NP & 436 & 436 & 419 & NP & 390 & 2 & 219 & 29 & 190 & NP & 46 & 17 & 29 & $\mathrm{NP}$ & & & \\
\hline 299-E33-333 & 0 & 9 & 30 & NP & 173.5 & 173.5 & 212 & NP? & ETD & & & 653 & 644 & 623 & NP & 480 & 480 & 441 & NP? & ETD & 9 & 164 & 21 & 143 & NP & $>80$ & 38.5 & $>42$ & NP? & ETD & & $\begin{array}{l}\text { Holocene =9' ditch fill; can't find } \\
\text { Stoller logs }\end{array}$ \\
\hline 299-E33-337 & NP & 0 & 55 & NP & 215 & NP? & 215 & NP & 281 & & & $\mathrm{NP}$ & 663 & 608 & NP & 448 & NP? & 448 & NP & 382 & 0 & 215 & 55 & 160 & NP & 66 & NP? & 66 & $\mathrm{NP}$ & & & \\
\hline 299-E33-338 & NP & 0 & 51.5 & NP & 212.5 & 212.5 & 222 & $\mathrm{NP}$ & 271 & & & NP & 657 & 605.5 & $\mathrm{NP}$ & 444.5 & 444.5 & 435 & $\mathrm{NP}$ & 386 & 0 & 212.5 & 51.5 & 161 & $\mathrm{NP}$ & 58.5 & 10 & 48.5 & $\mathrm{NP}$ & & & \\
\hline
\end{tabular}


Table E.1. (contd)

\begin{tabular}{|c|c|c|c|c|c|c|c|c|c|c|c|c|c|c|c|c|c|c|c|c|c|c|c|c|c|c|c|c|c|c|c|c|}
\hline \multirow[b]{2}{*}{ Well Name } & \multicolumn{11}{|c|}{ Contact Depths (ft) } & \multicolumn{9}{|c|}{ Contact Elevations (ft) } & \multicolumn{11}{|c|}{ Thickness (ft) } & \multirow[b]{2}{*}{ Comments } \\
\hline & 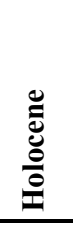 & $\begin{array}{l}\text { E } \\
\stackrel{0}{\theta} \\
\end{array}$ & 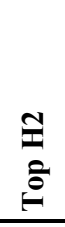 & 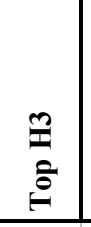 & $\begin{array}{l}己 \\
0 \\
0 \\
0 \\
\end{array}$ & 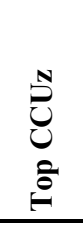 & $\begin{array}{l}0 \\
0 \\
0 \\
0 \\
0 \\
0\end{array}$ & 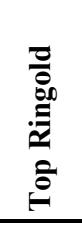 & है & 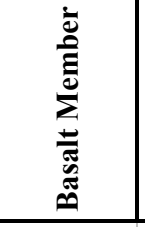 & 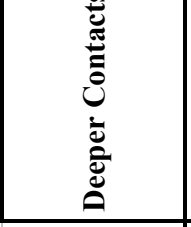 & 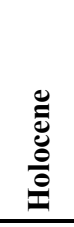 & 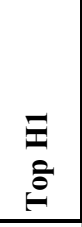 & $\frac{1}{3}$ & 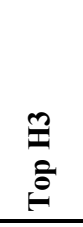 & $\begin{array}{l}己 \\
U \\
o \\
\tilde{\theta} \\
\end{array}$ & $\begin{array}{l}0 \\
0 \\
0 \\
0 \\
0\end{array}$ & $\begin{array}{l}\underbrace{\infty}_{0} \\
0 \\
0 \\
0 \\
0\end{array}$ & 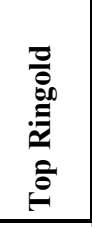 & 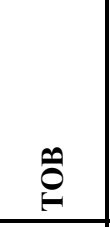 & 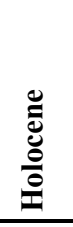 & 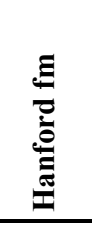 & $\Xi$ & $\Xi$ & $\mathbb{2}$ & 己 & 己्ठ & $\overbrace{0}^{\infty}$ & 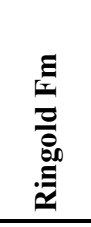 & 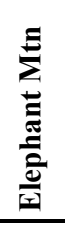 & 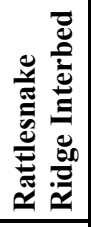 & \\
\hline 299-E33-340 & $\mathrm{NP}$ & 0 & 33 & NP & 131 & 131 & 154.5 & $\mathrm{NP}$ & 226 & $\begin{array}{c}\text { Elephant } \\
\text { Mtn }\end{array}$ & $\begin{array}{l}\text { RRI = } \\
298.5^{\prime}, \\
\text { Pomona = } \\
357.5^{\prime}\end{array}$ & NP & 618 & 585 & $\mathrm{NP}$ & 487 & 487 & 463 & NP & 392 & 0 & 131 & 33 & 98 & $\mathrm{NP}$ & 95 & 23 & 72 & $\mathrm{NP}$ & 73 & 59 & \\
\hline 299-E33-341 & $\mathrm{NP}$ & 0 & 40 & NP & 187 & 187 & 189 & NP & 232.5 & & & NP & 628 & 588 & $\mathrm{NP}$ & 441 & 441 & 439 & NP & 395 & 0 & 187 & 40 & 147 & NP & 46 & 2 & 44 & NP & & & \\
\hline 299-E33-343 & $\mathrm{NP}$ & 0 & 37 & NP & 213 & 213 & 239 & NP & 260.9 & & & NP & 652 & 615 & $\mathrm{NP}$ & 439 & 439 & 413 & NP & 391 & 0 & 213 & 37 & 176 & NP & 48 & 26 & 22 & NP & & & \\
\hline 299-E33-345 & 0 & 20 & 36 & NP & 217 & 217 & 244 & $\mathrm{NP}$ & 260.3 & & & 653 & 633 & 617 & $\mathrm{NP}$ & 436 & 436 & 409 & NP & 392.9 & 20 & 197 & 16 & 181 & NP & 43 & 27 & 16 & $\mathrm{NP}$ & & & \\
\hline 299-E34-2 & $\mathrm{NP}$ & 0 & 65 & NP & 205 & NP & 205 & $\mathrm{NP}$ & $\sim 241$ & & & NP & 637 & 572 & $\mathrm{NP}$ & 432 & NP & 432 & NP & 396 & 0 & 205 & 65 & 140 & $\mathrm{NP}$ & 36 & 0 & 36 & $\mathrm{NP}$ & & & \\
\hline 299-E34-5 & $\mathrm{NP}$ & 0 & NP & NP & NP & NP & NP & NP & $\sim 190$ & & & NP & 593 & NP & $\mathrm{NP}$ & NP & NP & NP & NP & 403 & 0 & 190 & 190 & NP & NP & $\mathrm{NP}$ & 0 & NP & NP & & & \\
\hline 299-E34-7 & NP & 0 & NP & NP & $190 ?$ & NP & $190 ?$ & NP & 205 & & & NP & 605 & NP & $\mathrm{NP}$ & 415 & NP & 415 & NP & 400 & 0 & 190 & 190 & NP & NP & 15 & NP & 15 & NP & & & \\
\hline 299-E34-9 & NP & 0 & 50 & NP & $197 ?$ & NP & $197 ?$ & NP & 234.5 & & & NP & 629 & 579 & $\mathrm{NP}$ & $432 ?$ & NP & $432 ?$ & NP & 394.8 & 0 & $197 ?$ & 50 & $147 ?$ & $\mathrm{NP}$ & 37.5 & $\mathrm{NP}$ & 37.5 & NP & & & \\
\hline 299-E34-11 & 0 & 20 & 50 & NP & $198 ?$ & $\mathrm{NP}$ & $198 ?$ & $\mathrm{NP}$ & 219 & & & 618 & 598 & 568 & $\mathrm{NP}$ & $420 ?$ & NP & $420 ?$ & NP & 399 & 20 & $178 ?$ & 30 & $148 ?$ & NP & $21 ?$ & $\mathrm{NP}$ & $21 ?$ & $\mathrm{NP}$ & & & \\
\hline 299-E35-1 & $\mathrm{NP}$ & 0 & NP & NP & NP & & & NP & 192 & $\begin{array}{l}\text { Elephant } \\
\text { Mtn }\end{array}$ & & NP & 599 & NP & $\mathrm{NP}$ & NP & & & NP & 406.8 & $\mathrm{NP}$ & 192 & 192 & NP & $\mathrm{NP}$ & $\mathrm{NP}$ & & & NP & & & \\
\hline 299-W11-88 & 0 & 7 & NP & NP & 70 & 70 & NP* & 155 & 487 & & & 726 & 719 & NP & $\mathrm{NP}$ & 656 & 656 & $\mathrm{NP}$ & 571 & 238.5 & 7 & 63 & 63 & $\mathrm{NP}$ & $\mathrm{NP}$ & 85 & 50 & NP & 332 & & & $\begin{array}{l}\mathrm{CCUz}=70-120^{\prime} ;{ }^{*} \mathrm{CCUc}=120-155^{\prime} \\
\mathrm{Rtf}=155-163^{\prime}, \mathrm{Re}=163-4877^{\prime} \\
\text { Changed from sonic to rotary } @ 460^{\prime}\end{array}$ \\
\hline 299-W12-1 & $\mathrm{NP}$ & 0 & 45 & 120 & NP & & & 190 & ETD & & & NP & 728 & 683 & 608 & NP & & & 538 & ETD & $\mathrm{NP}$ & 120 & 45 & 75 & 70 & $\mathrm{NP}$ & & & $>190$ & & & \\
\hline 699-44-64 & NP & 0 & 70 & $260 ?$ & NP? & & & $354 ?$ & 410 & & & NP & 727 & 657 & $467 ?$ & NP? & & & $373 ?$ & 317 & 0 & 260 & 70 & 190 & $94 ?$ & $\mathrm{NP}$ & & & $56 ?$ & & & \\
\hline 699-45-42 & $\mathrm{NP}$ & 0 & NP & & NP & & & $160 ?$ & 190 & $\begin{array}{l}\text { Elephant } \\
\text { Mtn? }\end{array}$ & & NP & 579 & NP & & $\mathrm{NP}$ & NP & NP & $419 ?$ & 389 & 0 & 160 & 160 & NP & & $\mathrm{NP}$ & & & $30 ?$ & & & \\
\hline 699-45-69C & 0 & 1 & 140 & $220 ?$ & $?$ & & & 295 & 455 & & & 727 & 726 & 587 & $507 ?$ & $?$ & & & 432 & 272 & 1 & 219 & 139 & 80 & 75 & $?$ & & & 160 & & & \begin{tabular}{|} 
Almost 40' of Rlm starting @ $325^{\prime} ; \mathrm{Ra}$ \\
@ 364' depth. Changed from rotary to \\
sonic $20 \mathrm{ft}$ above basalt
\end{tabular} \\
\hline 699-47-42 & $?$ & $?$ & $?$ & NP & $?$ & & & $?$ & 68 & $\begin{array}{c}\text { Elephant } \\
\text { Mtn }\end{array}$ & 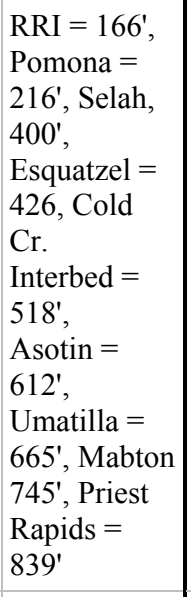 & $?$ & ? & $?$ & $\mathrm{NP}$ & $?$ & & & $?$ & 403 & $?$ & $?$ & $?$ & $?$ & NP & $?$ & $?$ & $?$ & $?$ & 98 & 50 & $\begin{array}{l}\text { Little or no information on post-basalt } \\
\text { sediments }\end{array}$ \\
\hline 699-47-46A & 0 & 1 & NP & NP & NP? & NP & NP? & NP & 174 & $\begin{array}{c}\text { Elephant } \\
\text { Mtn }\end{array}$ & & 582 & 581 & NP & $\mathrm{NP}$ & NP? & NP & $\mathrm{NP} ?$ & NP & 408 & 1 & 173 & 173 & NP & NP & NP? & NP & NP? & NP & & & \\
\hline
\end{tabular}


Table E.1. (contd)

\begin{tabular}{|c|c|c|c|c|c|c|c|c|c|c|c|c|c|c|c|c|c|c|c|c|c|c|c|c|c|c|c|c|c|c|c|c|}
\hline \multirow[b]{2}{*}{ Well Name } & \multicolumn{11}{|c|}{ Contact Depths (ft) } & \multicolumn{9}{|c|}{ Contact Elevations (ft) } & \multicolumn{11}{|c|}{ Thickness (ft) } & \multirow[b]{2}{*}{ Comments } \\
\hline & 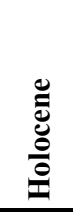 & \begin{tabular}{|l|} 
\\
0 \\
$\vdots$ \\
\end{tabular} & 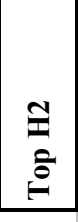 & $\begin{array}{l}\stackrel{0}{7} \\
\stackrel{2}{2} \\
\end{array}$ & 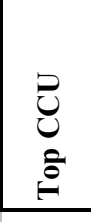 & 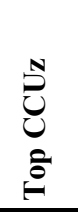 & 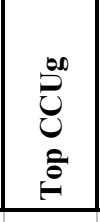 & 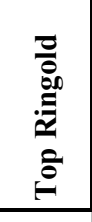 & $\stackrel{\text { ڤै }}{2}$ & 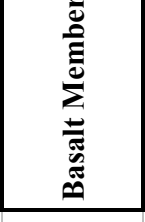 & 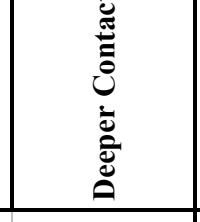 & 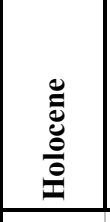 & $\begin{array}{l} \pm \\
\vdots \\
\\
\end{array}$ & 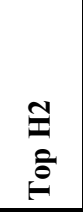 & 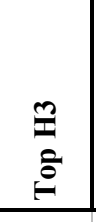 & 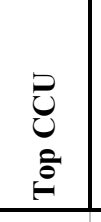 & 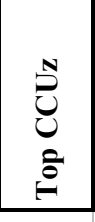 & $\begin{array}{l}\overbrace{0}^{\infty} \\
\stackrel{0}{0} \\
\stackrel{0}{0}\end{array}$ & 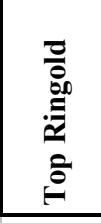 & $\stackrel{0}{0}$ & 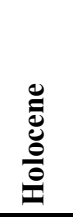 & 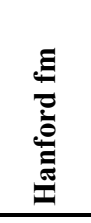 & $\Xi$ & $\underline{\Xi}$ & $\mathscr{\Xi}$ & 己 & 葛 & $己^{\infty}$ & 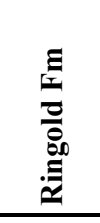 & 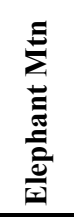 & 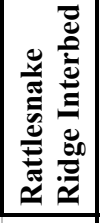 & \\
\hline 699-47-50 & NP & 0 & NP & NP & NP? & $\mathrm{NP}$ & NP? & $\mathrm{NP}$ & 215 & $\begin{array}{c}\text { Elephant } \\
\text { Mtn }\end{array}$ & RRI $=260^{\prime}$ & NP & 585 & $\mathrm{NP}$ & $\mathrm{NP}$ & $\mathrm{NP} ?$ & $\mathrm{NP}$ & NP? & NP & 370 & $\mathrm{NP}$ & 215 & 215 & NP & NP & NP? & NP & $\mathrm{NP}$ ? & NP & 45 & & Drillers log mislabeled as 699-48-50 \\
\hline 699-47-51 & NP & 0 & NP & NP & NP & $\mathrm{NP}$ & NP & $\mathrm{NP}$ & 159 & & & $\mathrm{NP}$ & 585 & $\mathrm{NP}$ & $\mathrm{NP}$ & $\mathrm{NP}$ & NP & $\mathrm{NP}$ & $\mathrm{NP}$ & 426 & $\mathrm{NP}$ & 159 & 159 & NP & NP & NP & NP & NP & $\mathrm{NP}$ & & & No water encountered during drilling \\
\hline 699-47-60 & 0 & 5 & $\mathrm{NP}$ & NP & 255 & $\mathrm{NP}$ & 255 & $\mathrm{NP}$ & 277.5 & $\begin{array}{c}\text { Elephant } \\
\text { Mtn }\end{array}$ & & 652 & 647 & $\mathrm{NP}$ & $\mathrm{NP}$ & 397 & $\mathrm{NP}$ & 397 & NP & 375 & 5 & 250 & 250 & NP & $\mathrm{NP}$ & 22 & NP & 22 & NP & & & $\begin{array}{l}\text { TOB reported at } 284 \text { ' but casing } \\
\text { stopped at } 277.5=\text { prob. TOB }\end{array}$ \\
\hline 699-48-48B & NP & 0 & NP & NP & NP & & & $\mathrm{NP}$ & 205 & $\begin{array}{l}\text { Elephant } \\
\text { Mtn }\end{array}$ & 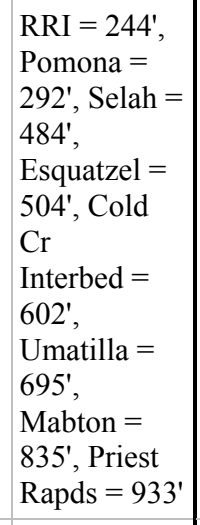 & NP & 573 & $\mathrm{NP}$ & NP & NP & & & $\mathrm{NP}$ & 368 & $\mathrm{NP}$ & 205 & 205 & NP & NP & $?$ & ? & $?$ & NP & 39 & 48 & $\begin{array}{l}\text { Consolidated, open hole, brownish } \\
\text { starting @140' = Ringold? }\end{array}$ \\
\hline 699-48-49 & $?$ & $?$ & $?$ & $\mathrm{NP}$ & $?$ & $?$ & $?$ & $?$ & $?$ & & & $?$ & $?$ & $?$ & NP & $?$ & $?$ & $?$ & ? & ? & $?$ & ? & ? & $?$ & $\mathrm{NP}$ & $?$ & $?$ & ? & ? & & & \\
\hline 699-48-50 & NP & 0 & NP & $\mathrm{NP}$ & $\mathrm{NP}$ & & & $\mathrm{NP}$ & 195.6 & $\begin{array}{l}\text { Elephant } \\
\text { Mtn }\end{array}$ & & NP & 575 & $\mathrm{NP}$ & $\mathrm{NP}$ & NP & & & $\mathrm{NP}$ & 379 & $\mathrm{NP}$ & 196 & 196 & NP & $\mathrm{NP}$ & $\mathrm{NP}$ & $\mathrm{NP}$ & NP & NP & & & Change to hard tool @177' \\
\hline 699-48-50B & $\mathrm{NP}$ & 0 & 43 & $\mathrm{NP}$ & 121 & 121 & $170 ?$ & 185 & 209.5 & $\begin{array}{c}\text { Elephant } \\
\text { Mtn }\end{array}$ & & NP & 609 & 599 & NP & 488 & 488 & $439 ?$ & 424 & 399 & $\mathrm{NP}$ & 121 & 10 & 111 & $\mathrm{NP}$ & 64 & $49 ?$ & $15 ?$ & 25 & & & \\
\hline 699-48-71 & NP & 0 & NP & NP & NP & & & $170 ?$ & ETD & & & NP & 690 & $\mathrm{NP}$ & NP & $\mathrm{NP}$ & & & $520 ?$ & ETD & $\mathrm{NP}$ & 170 & 170 & NP & NP & NP & & & $>135$ & & & \\
\hline 699-49-55A & NP & 0 & 15 & NP & 50 & 50 & 99 & $118 ?$ & 135 & $\begin{array}{c}\text { Elephant } \\
\text { Mtn }\end{array}$ & & $\mathrm{NP}$ & 532 & 517 & NP & 482 & 482 & 433 & ? & 397 & $\mathrm{NP}$ & 50 & 15 & 35 & NP & 68 & 49 & 6 & $?$ & & & $\begin{array}{l}>30^{\prime}=\mathrm{DB} \text {, casing stopped driving } \\
@ 135^{\prime}=\mathrm{TOB} \text { ? }\end{array}$ \\
\hline 699-49-55B & $\mathrm{NP}$ & 0 & $?$ & $\mathrm{NP}$ & ? & ? & $?$ & 105 & 136 & $\begin{array}{l}\text { Elephant } \\
\text { Mtn }\end{array}$ & $\begin{array}{l}\text { RRI = 183', } \\
\text { Pomona = } \\
\text { 226' }\end{array}$ & NP & 532 & ? & NP & ? & ? & ? & 427 & 396 & $\mathrm{NP}$ & ? & ? & & NP & $?$ & ? & $?$ & 31 & 47 & 43 & \\
\hline 699-49-57A & 0 & 3 & 25 & $\mathrm{NP}$ & 95 & 95 & 115 & $\mathrm{NP}$ & 162 & $\begin{array}{c}\text { Elephant } \\
\text { Mtn }\end{array}$ & & 554 & 551 & 529 & NP & 459 & 459 & 439 & NP & 392 & 3 & 42 & 22 & 20 & $\mathrm{NP}$ & 67 & 20 & 47 & $\mathrm{NP}$ & & & \\
\hline 699-49-57B & 0 & 4 & 18 & NP & 111 & 111 & 115 & $\mathrm{NP}$ & 162.5 & $\begin{array}{l}\text { Elephant } \\
\text { Mtn }\end{array}$ & $\mathrm{RRI}=215^{\prime}$ & 556.5 & 553 & 539 & $\mathrm{NP}$ & 446 & 446 & 442 & NP & 394 & 4 & 107 & 14 & 93 & NP & 52 & 4 & 48 & NP & 53 & & \\
\hline 699-49-71 & 0 & 3 & & & & & & & & & & & & & & & & & & & & & & & & & & & & & & \\
\hline 699-50-42 & NP & 0 & NP & $\mathrm{NP}$ & $\mathrm{NP}$ & $\mathrm{NP}$ & $\mathrm{NP}$ & 38 & 65 & $\begin{array}{c}\text { Elephant } \\
\text { Mtn }\end{array}$ & & $\mathrm{NP}$ & 468 & $\mathrm{NP}$ & $\mathrm{NP}$ & $\mathrm{NP}$ & NP & $\mathrm{NP}$ & 430 & 403 & $\mathrm{NP}$ & 38 & 38 & NP & $\mathrm{NP}$ & $\mathrm{NP}$ & $\mathrm{NP}$ & $\mathrm{NP}$ & 27 & & & Calcareous fines from 35-45' \\
\hline 699-50-45 & $\mathrm{NP}$ & 0 & NP & NP & $\mathrm{NP}$ & & & $\mathrm{NP}$ & 37 & $\begin{array}{c}\text { Elephant } \\
\text { Mtn }\end{array}$ & $\mathrm{RRI}=130^{\prime}$ & $\mathrm{NP}$ & 453 & $\mathrm{NP}$ & NP & $\mathrm{NP}$ & & & NP & 416 & NP & 37 & 37 & $\mathrm{NP}$ & $\mathrm{NP}$ & $\mathrm{NP}$ & $\mathrm{NP}$ & $\mathrm{NP}$ & $\mathrm{NP}$ & 93 & & Air rotary through basalt from 4 \\
\hline
\end{tabular}


Table E.1. (contd)

\begin{tabular}{|c|c|c|c|c|c|c|c|c|c|c|c|c|c|c|c|c|c|c|c|c|c|c|c|c|c|c|c|c|c|c|c|c|}
\hline \multirow[b]{2}{*}{ Well Name } & \multicolumn{11}{|c|}{ Contact Depths (ft) } & \multicolumn{9}{|c|}{ Contact Elevations (ft) } & \multicolumn{11}{|c|}{ Thickness (ft) } & \multirow[b]{2}{*}{ Comments } \\
\hline & 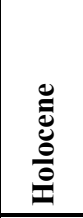 & $\begin{array}{l}E \\
\vdots \\
0\end{array}$ & $\begin{array}{l}\mathbb{I} \\
0 \\
0 \\
\end{array}$ & 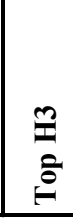 & $\begin{array}{l}\text { D } \\
0 \\
\tilde{a} \\
0\end{array}$ & 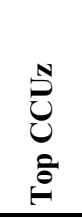 & 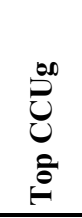 & 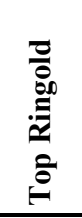 & $\stackrel{0}{\varrho}$ & 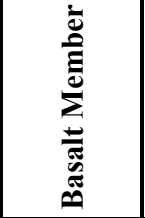 & 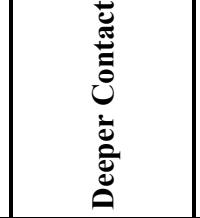 & 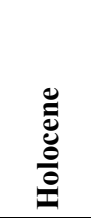 & 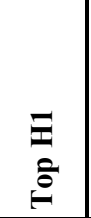 & $\begin{array}{l}\mathfrak{1} \\
\frac{1}{2} \\
0\end{array}$ & 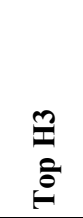 & 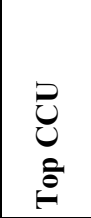 & $\begin{array}{l}0 \\
0 \\
0 \\
0 \\
0\end{array}$ & $\begin{array}{l}\underbrace{\infty}_{0} \\
0 \\
0 \\
0\end{array}$ & 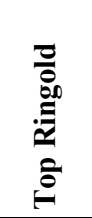 & $\stackrel{\infty}{\varrho}$ & 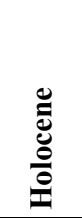 & 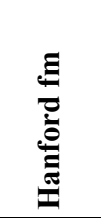 & $\Xi$ & $\Xi$ & $\cong$ & Z & 记 & $\overbrace{0}^{\infty}$ & 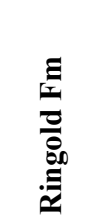 & 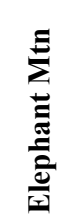 & 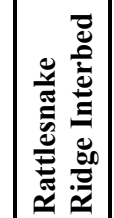 & \\
\hline \begin{tabular}{|l|}
$699-50-48 \mathrm{~A}$ \\
\end{tabular} & $\mathrm{NP}$ & 0 & $\mathrm{NP}$ & $\mathrm{NP}$ & $\mathrm{NP}$ & & & $\mathrm{NP}$ & 118 & $\begin{array}{c}\text { Elephant } \\
\text { Mtn }\end{array}$ & 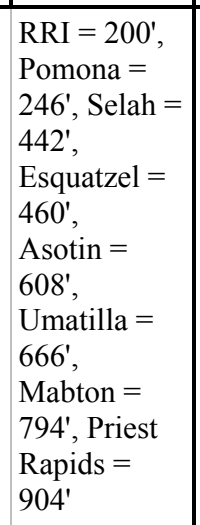 & $\mathrm{NP}$ & 553 & $\mathrm{NP}$ & $\mathrm{NP}$ & $\mathrm{NP}$ & & & $\mathrm{NP}$ & 435 & $\mathrm{NP}$ & $118 ?$ & $118 ?$ & $\mathrm{NP}$ & $\mathrm{NP}$ & NP? & $\mathrm{NP}$ ? & $\mathrm{NP}$ ? & $\mathrm{NP}$ & 82 & 46 & CT to $173^{\prime}$, deepened via RC in 1969 \\
\hline 699-50-48B & NP & 0 & NP & NP & NP & NP & $\mathrm{NP}$ & NP & 111 & $\begin{array}{l}\text { Elephant } \\
\text { Mtn }\end{array}$ & $\begin{array}{l}\text { RRI = 210', } \\
\text { Pomona = } \\
250^{\prime}\end{array}$ & NP & 552 & NP & $\mathrm{NP}$ & NP & NP & NP & $\mathrm{NP}$ & 441 & $\mathrm{NP}$ & 111 & 111 & NP & NP & NP & $\mathrm{NP}$ & $\mathrm{NP}$ & $\mathrm{NP}$ & 99 & 40 & $\begin{array}{l}\text { AR from 119-213'; no bldrs, } \\
\text { compacted starting at } 45^{\prime}\end{array}$ \\
\hline 699-50-53A & NP & 0 & 80 & NP & 140 & NP & 140 & NP & 156.5 & $\begin{array}{c}\text { Elephant } \\
\text { Mtn }\end{array}$ & & $\mathrm{NP}$ & 558 & 478 & NP & 418 & NP & 418 & $\mathrm{NP}$ & 402 & NP & 140 & 80 & 60 & NP & 16 & $\mathrm{NP}$ & 16 & $\mathrm{NP}$ & & & \\
\hline 699-50-53B & NP & 0 & 61 & NP & 140 & NP & 140 & NP & 155.8 & $\begin{array}{c}\text { Elephant } \\
\text { Mtn }\end{array}$ & $\mathrm{RRI}=205^{\prime}$ & NP & 558 & 497 & $\mathrm{NP}$ & 418 & NP & 418 & $\mathrm{NP}$ & 403 & $\mathrm{NP}$ & 140 & 61 & 79 & NP & 15 & $\mathrm{NP}$ & 15 & $\mathrm{NP}$ & 49 & & $\begin{array}{l}\text { Geologist log should be available but } \\
\text { can't find anywhere }\end{array}$ \\
\hline 699-50-59 & 0 & 1 & NP & NP & $\mathrm{NP}$ & & & $\mathrm{NP}$ & 167 & $\begin{array}{l}\text { Elephant } \\
\text { Mtn }\end{array}$ & & 565 & 564 & $\mathrm{NP}$ & $\mathrm{NP}$ & $\mathrm{NP}$ & & & $\mathrm{NP}$ & 397 & 1 & 167 & 167 & $\mathrm{NP}$ & $\mathrm{NP}$ & NP & $\mathrm{NP}$ & $\mathrm{NP}$ & $\mathrm{NP}$ & & & \\
\hline 699-50-74 & 0 & 7 & NP & NP & NP & NP & $\mathrm{NP}$ & $90 ?$ & $\sim 336$ & & & 658 & 651 & NP & $\mathrm{NP}$ & NP & NP & NP & $568 ?$ & $\sim 322$ & 7 & $83 ?$ & 83 & NP & $\mathrm{NP}$ & NP & $\mathrm{NP}$ & $\mathrm{NP}$ & $123 ?$ & & & \\
\hline 699-51-46 & NP & 0 & NP & NP & NP & & & $\mathrm{NP}$ & 12 & $\begin{array}{l}\text { Elephant } \\
\text { Mtn }\end{array}$ & $\begin{array}{l}\text { RRI = 119', } \\
\text { Pomona = } \\
165^{\prime}\end{array}$ & NP & 446 & $\mathrm{NP}$ & $\mathrm{NP}$ & NP & & & $\mathrm{NP}$ & 434 & $\mathrm{NP}$ & 12 & 12 & NP & $\mathrm{NP}$ & $\mathrm{NP}$ & $\mathrm{NP}$ & $\mathrm{NP}$ & $\mathrm{NP}$ & 107 & 46 & $\begin{array}{l}\text { Drill log mislabeled } 51-47, \text { HT from } \\
0-177^{\prime} \text { and } 120-163^{\prime}\end{array}$ \\
\hline 699-51-63 & NP & 0 & NP & NP & NP & & & $\mathrm{NP}$ & $183.5 ?$ & $\begin{array}{c}\text { Elephant } \\
\text { Mtn }\end{array}$ & & NP & 573 & $\mathrm{NP}$ & $\mathrm{NP}$ & NP & & & $\mathrm{NP}$ & $390 ?$ & $\mathrm{NP}$ & 184 & 183.5 & $\mathrm{NP}$ & $\mathrm{NP}$ & $\mathrm{NP}$ & $\mathrm{NP}$ & $\mathrm{NP}$ & $\mathrm{NP}$ & & & TOB or boulder? \\
\hline 699-52-46A & NP & 0 & NP & NP & NP? & & & 40 & 50 & $\begin{array}{l}\text { Elephant } \\
\text { Mtn }\end{array}$ & $\begin{array}{l}\text { RRI = 169', } \\
\text { Pomona = } \\
225^{\prime}\end{array}$ & NP & 457 & NP & $\mathrm{NP}$ & NP? & & & 417 & 407 & $\mathrm{NP}$ & 40 & 40 & $\mathrm{NP}$ & $\mathrm{NP}$ & NP? & NP? & NP? & 10 & 119 & 56 & Sticky clay @40' \\
\hline 699-52-46B & ? & $?$ & $?$ & NP & $?$ & & & $?$ & 44 & $\begin{array}{l}\text { Elephant } \\
\text { Mtn }\end{array}$ & & $?$ & ? & $?$ & $\mathrm{NP}$ & $?$ & & & ? & $?$ & ? & $?$ & ? & $?$ & NP & ? & ? & ? & $?$ & & & \\
\hline 699-52-48 & 0 & 5 & NP & NP & NP & & & $\mathrm{NP}$ & 28 & $\begin{array}{c}\text { Elephant } \\
\text { Mtn }\end{array}$ & $\begin{array}{l}\text { RRI = 149', } \\
\text { Pomona = } \\
195^{\prime}\end{array}$ & 469 & 464 & NP & NP & $\mathrm{NP}$ & & & NP & 441 & 5 & 23 & 23 & NP & $\mathrm{NP}$ & $\mathrm{NP}$ & NP & $\mathrm{NP}$ & $\mathrm{NP}$ & 121 & 46 & \\
\hline
\end{tabular}


Table E.1. (contd)

\begin{tabular}{|c|c|c|c|c|c|c|c|c|c|c|c|c|c|c|c|c|c|c|c|c|c|c|c|c|c|c|c|c|c|c|c|c|}
\hline \multirow[b]{2}{*}{ Well Name } & \multicolumn{11}{|c|}{ Contact Depths (ft) } & \multicolumn{9}{|c|}{ Contact Elevations (ft) } & \multicolumn{11}{|c|}{ Thickness (ft) } & \multirow[b]{2}{*}{ Comments } \\
\hline & 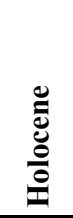 & \begin{tabular}{|l|} 
\\
$\vdots$ \\
$\tilde{\sigma}$ \\
\end{tabular} & 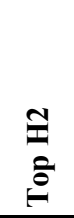 & 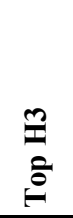 & $\begin{array}{l}己 \\
U \\
\tilde{\theta} \\
\theta\end{array}$ & $\begin{array}{l}\tilde{0} \\
0 \\
\hat{0} \\
\hat{\theta}\end{array}$ & $\begin{array}{l}\underbrace{\infty}_{0} \\
0 \\
\tilde{0} \\
0\end{array}$ & 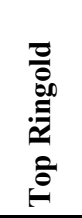 & $\stackrel{0}{0}$ & 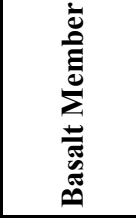 & 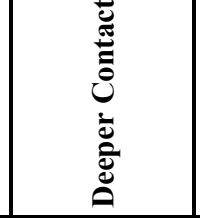 & 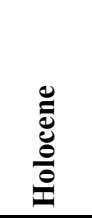 & 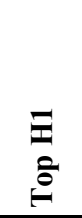 & 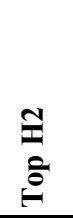 & 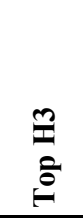 & 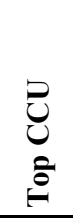 & $\begin{array}{l}0 \\
0 \\
u \\
o \\
\tilde{\theta}\end{array}$ & $\begin{array}{l}\underbrace{\infty}_{0} \\
0 \\
0 \\
0 \\
0\end{array}$ & 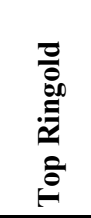 & है & 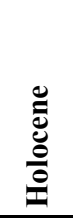 & 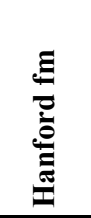 & $\Xi$ & $\cong$ & $\cong$ & 己 & 己 & $\overbrace{}^{\infty}$ & 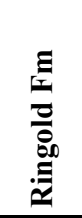 & 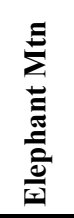 & 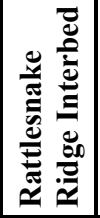 & \\
\hline 699-52-52 & $\mathrm{NP}$ & 0 & $\mathrm{NP}$ & $\mathrm{NP}$ & $\mathrm{NP}$ & & & $\mathrm{NP}$ & 148 & $\begin{array}{c}\text { Elephant } \\
\text { Mtn }\end{array}$ & $\begin{array}{l}\text { RRI }=2222^{\prime}, \\
\text { Pomona }= \\
2777^{\prime}, \text { Selah }= \\
462^{\prime}, \\
\text { Esquatzel }= \\
484^{\prime}, \text { Cold } \\
\text { Cr. } \\
\text { Interbed = } \\
594^{\prime}, \text { } \\
\text { Astin }= \\
614^{\prime}, \\
\text { Umatilla }= \\
692^{\prime}, \\
\text { Mabton = } \\
933^{\prime}\end{array}$ & $\mathrm{NP}$ & 561 & $\mathrm{NP}$ & $\mathrm{NP}$ & $\mathrm{NP}$ & & & $\mathrm{NP}$ & 413 & $\mathrm{NP}$ & 148 & 148 & $\mathrm{NP}$ & $\mathrm{NP}$ & $\mathrm{NP}$ & $\mathrm{NP}$ & $\mathrm{NP}$ & $\mathrm{NP}$ & 74 & 55 & \\
\hline 699-52-54 & NP & 0 & 92 & $\mathrm{NP}$ & NP & & & NP & 167.4 & $\begin{array}{c}\text { Elephant } \\
\text { Mtn }\end{array}$ & & $\mathrm{NP}$ & 569 & 477 & $\mathrm{NP}$ & NP & & & $\mathrm{NP}$ & 402 & $\mathrm{NP}$ & 167 & 92 & 75 & $\mathrm{NP}$ & $\mathrm{NP}$ & $\mathrm{NP}$ & $\mathrm{NP}$ & NP & & & \\
\hline 699-52-55 & 0 & 3 & 123 & NP & 146 & 146 & 154 & NP & 177.2 & $\begin{array}{l}\text { Elephant } \\
\text { Mtn }\end{array}$ & & 574 & 571 & 451 & $\mathrm{NP}$ & 428 & 428 & 420 & $\mathrm{NP}$ & 397 & 3 & 143 & 120 & 23 & NP & 31 & 8 & 23 & $\mathrm{NP}$ & & & $\begin{array}{l}\text { Low-K constant-rate pump test in } \\
\text { CCUg }\end{array}$ \\
\hline 699-52-55B & 0 & 5 & 127 & $\mathrm{NP}$ & 144 & 144 & 158 & NP & 176.5 & $\begin{array}{c}\text { Elephant } \\
\text { Mtn }\end{array}$ & $\begin{array}{l}\text { RRI = 222', } \\
\text { Pomona = } \\
286^{\prime}\end{array}$ & 574 & 569 & 447 & NP & 430 & 430 & 416 & $\mathrm{NP}$ & 397 & 5 & 139 & 122 & 17 & $\mathrm{NP}$ & 33 & 14 & 19 & NP & 46 & 64 & \\
\hline 699-52-57 & NP & 0 & 75 & NP & 105 & 105 & 118 & NP & 159.7 & $\begin{array}{c}\text { Elephant } \\
\text { Mtn }\end{array}$ & & $\mathrm{NP}$ & 562 & 487 & NP & 457 & 457 & 444 & NP & 402 & NP & 105 & 75 & 30 & NP & 55 & 13 & 42 & NP & & & Same well as 699-51-56 (A8828) \\
\hline 699-53-47A & NP & 0 & NP & NP & NP & & & NP & 41.5 & $\begin{array}{l}\text { Elephant } \\
\text { Mtn? }\end{array}$ & & $\mathrm{NP}$ & 439 & NP & NP & NP & & & NP & 398 & NP & 42 & 41.5 & NP & $\mathrm{NP}$ & $\mathrm{NP}$ & NP & NP & NP & & & No TOB on drillers log \\
\hline 699-53-48A & 0 & 1 & NP & NP & $\mathrm{NP}$ & NP & $\mathrm{NP}$ & 37 & 43 & $\begin{array}{l}\text { Elephant } \\
\text { Mtn? }\end{array}$ & & 443 & 442 & $\mathrm{NP}$ & NP & NP & NP & $\mathrm{NP}$ & 406 & 400 & 1 & 36 & 36 & NP & NP & $\mathrm{NP}$ & NP & NP & 6 & & & \\
\hline 699-53-48B & NP & 0 & NP & NP & $\mathrm{NP}$ & NP & $\mathrm{NP}$ & 37 & 44 & $\begin{array}{l}\text { Elephant } \\
\text { Mtn? }\end{array}$ & & $\mathrm{NP}$ & 444 & $\mathrm{NP}$ & NP & NP & NP & $\mathrm{NP}$ & 407 & 400 & NP & 37 & 37 & NP & NP & $\mathrm{NP}$ & NP & NP & 7 & & & \\
\hline 699-53-50 & NP & 0 & NP & NP & NP & & & $\mathrm{NP}$ & 36 & $\begin{array}{l}\text { Elephant } \\
\text { Mtn }\end{array}$ & $\begin{array}{l}\text { RRI = 145', } \\
\text { Pomona = } \\
192^{\prime}\end{array}$ & $\mathrm{NP}$ & 446 & $\mathrm{NP}$ & $\mathrm{NP}$ & NP & & & $\mathrm{NP}$ & 410 & $\mathrm{NP}$ & 36 & 36 & NP & $\mathrm{NP}$ & $\mathrm{NP}$ & $\mathrm{NP}$ & NP & NP & 109 & 47 & \\
\hline 699-53-55A & NP & 0 & NP & NP & $\mathrm{NP}$ & & & NP & $258^{*}$ & $\begin{array}{c}\text { *RRI } \\
\text { window }\end{array}$ & $\begin{array}{l}\text { RRI= 258', } \\
\text { Pomona = } \\
\text { 295', }\end{array}$ & $\mathrm{NP}$ & 577 & $\mathrm{NP}$ & NP & NP & & & NP & $319 ?^{*}$ & NP & 258 & 258 & NP & $\mathrm{NP}$ & $\mathrm{NP}$ & NP & $\mathrm{NP}$ & NP & $\mathrm{NP}$ & 37 & $\begin{array}{l}\text { TOB may be down to } 300 \mathrm{ft} \text { depth; } \\
\text { Hanford ff over Ellensburg }\end{array}$ \\
\hline 699-53-55B & 0 & 5 & NP & $\mathrm{NP}$ & NP & & & $\mathrm{NP}$ & $251^{*}$ & $\begin{array}{c}* \text { RRI } \\
\text { window }\end{array}$ & $\mathrm{RRI}=251^{\prime}$ & 578 & 573 & $\mathrm{NP}$ & $\mathrm{NP}$ & NP & & & $\mathrm{NP}$ & 327?** & 5 & 246 & 246 & $\mathrm{NP}$ & $\mathrm{NP}$ & $\mathrm{NP}$ & $\mathrm{NP}$ & NP & $\mathrm{NP}$ & $\mathrm{NP}$ & & \\
\hline 699-54-42 & 0 & 15 & NP & NP & NP & & & $75 ?$ & $100^{*}$ & $\begin{array}{c}\text { *RRI } \\
\text { window }\end{array}$ & $\begin{array}{l}\text { RRI = 100', } \\
\text { Pomona = } \\
\text { 199' }\end{array}$ & 513 & 498 & $\mathrm{NP}$ & $\mathrm{NP}$ & NP & & & $438 ?$ & $413^{*}$ & 15 & $60 ?$ & $60 ?$ & NP & $\mathrm{NP}$ & $\mathrm{NP}$ & $\mathrm{NP}$ & $\mathrm{NP}$ & $25 ?$ & $\mathrm{NP}$ & 99 & \\
\hline 699-54-45A & NP & 0 & NP & NP & $\mathrm{NP}$ & & & NP & $75^{*}$ & $\begin{array}{c}\text { *RRI } \\
\text { window? }\end{array}$ & & $\mathrm{NP}$ & 495 & $\mathrm{NP}$ & NP & NP & & & $\mathrm{NP}$ & $420^{*}$ & NP & 75 & 75 & NP & NP & $\mathrm{NP}$ & NP & NP & NP & $\mathrm{NP}$ & & \\
\hline 699-54-45B & NP & 0 & NP & NP & $\mathrm{NP}$ & & & 50 & $\leq 180$ & $?$ & $\begin{array}{l}\text { Selah? = } \\
304\end{array}$ & $\mathrm{NP}$ & 495 & $\mathrm{NP}$ & $\mathrm{NP}$ & NP & & & 445 & $\geq 315$ & NP & 50 & 50 & NP & NP & $\mathrm{NP}$ & $\mathrm{NP}$ & $\mathrm{NP}$ & $>24$ & & & 74-175' undocumented across TOB \\
\hline
\end{tabular}


Table E.1. (contd)

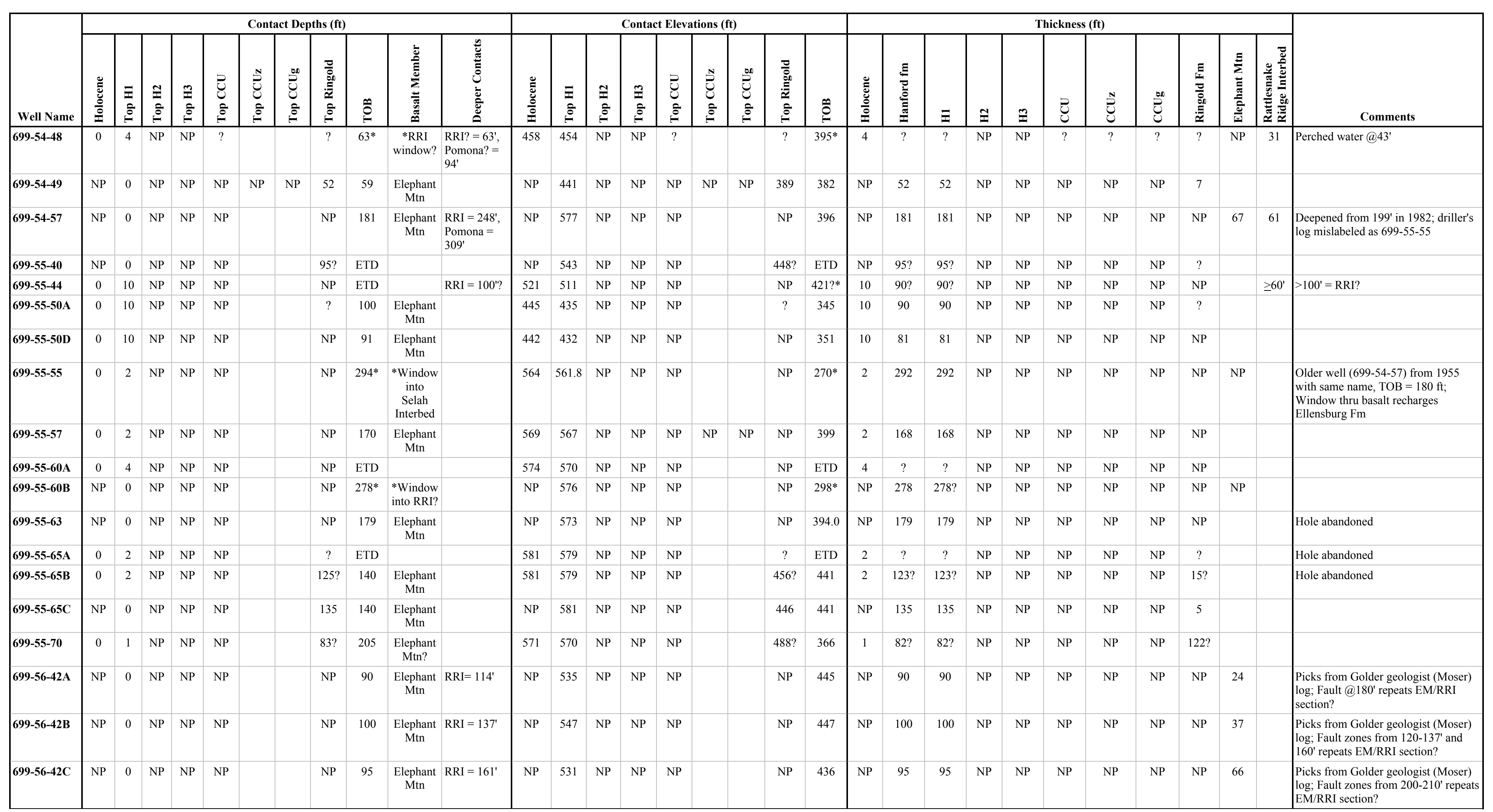


Table E.1. (contd)

\begin{tabular}{|c|c|c|c|c|c|c|c|c|c|c|c|c|c|c|c|c|c|c|c|c|c|c|c|c|c|c|c|c|c|c|c|c|}
\hline \multirow[b]{2}{*}{ Well Name } & \multicolumn{11}{|c|}{ Contact Depths (ft) } & \multicolumn{9}{|c|}{ Contact Elevations (ft) } & \multicolumn{11}{|c|}{ Thickness (ft) } & \multirow[b]{2}{*}{ Comments } \\
\hline & 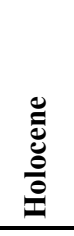 & \begin{tabular}{|l|}
$E$ \\
0 \\
0 \\
\end{tabular} & 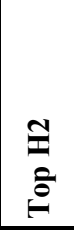 & 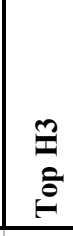 & 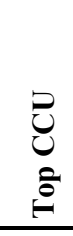 & $\begin{array}{l}0 \\
0 \\
0 \\
0 \\
0\end{array}$ & 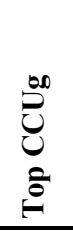 & 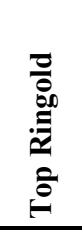 & $\stackrel{\text { ô }}{\varrho}$ & 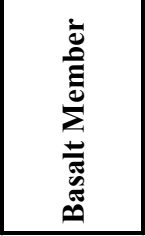 & 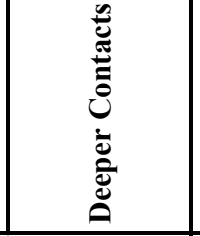 & 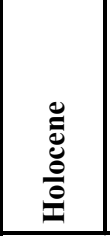 & 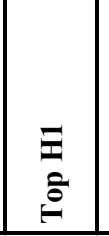 & $\begin{array}{l}\mathbb{1} \\
\frac{1}{2} \\
\end{array}$ & 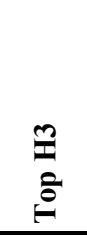 & 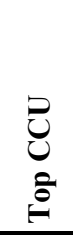 & 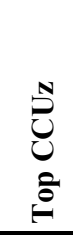 & $\begin{array}{l}\overbrace{0}^{\infty} \\
0 \\
0 \\
0 \\
0\end{array}$ & 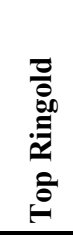 & है & 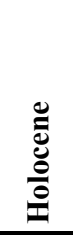 & 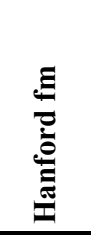 & $\Xi$ & $\mathbb{I}$ & $\cong$ & 己 & 己्己 & $\overbrace{0}^{\infty}$ & 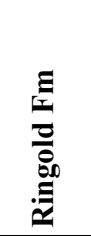 & 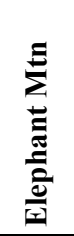 & 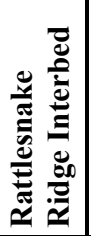 & \\
\hline 699-56-42D & $\mathrm{NP}$ & 0 & $\mathrm{NP}$ & NP & $\mathrm{NP}$ & & & $\mathrm{NP}$ & 48 & $\begin{array}{c}\text { Elephant } \\
\text { Mtn }\end{array}$ & $\begin{array}{l}\text { RRI }=360^{\prime}, \\
\text { Pomona = } \\
406.5^{\prime}, \\
\text { Selah }= \\
593.5, \\
\text { Esquatzel = } \\
624^{\prime}\end{array}$ & $\mathrm{NP}$ & 563 & $\mathrm{NP}$ & $\mathrm{NP}$ & $\mathrm{NP}$ & & & $\mathrm{NP}$ & 515 & $\mathrm{NP}$ & 48 & 48 & $\mathrm{NP}$ & $\mathrm{NP}$ & $\mathrm{NP}$ & $\mathrm{NP}$ & $\mathrm{NP}$ & $\mathrm{NP}$ & 312 & 47 & No faulting reported \\
\hline 699-56-42E & $\mathrm{NP}$ & 0 & NP & NP & $\mathrm{NP}$ & & & $\mathrm{NP}$ & 85 & $\begin{array}{l}\text { Elephant } \\
\text { Mtn }\end{array}$ & $\begin{array}{l}\text { RRI }=180^{\prime}, \\
\text { Pomona }= \\
395^{\prime}, \text { Selah }= \\
575^{\prime}, \\
\text { Esquatzel }= \\
601^{\prime}\end{array}$ & NP & 541 & NP & NP & $\mathrm{NP}$ & & & $\mathrm{NP}$ & 456 & $\mathrm{NP}$ & 85 & 85 & $\mathrm{NP}$ & $\mathrm{NP}$ & $\mathrm{NP}$ & $\mathrm{NP}$ & $\mathrm{NP}$ & $\mathrm{NP}$ & 95 & 215 & $\begin{array}{l}\text { Picks from Golder geologist (Moser) } \\
\text { log; Fault zones at } 229 \text { 'repeats } \\
\text { EM/RRI section? }\end{array}$ \\
\hline 699-56-42F & NP & 0 & NP & NP & NP & & & NP & 40 & $\begin{array}{l}\text { Elephant } \\
\text { Mtn }\end{array}$ & $\begin{array}{l}\text { RRI }=386, \\
\text { Pomona }= \\
\text { 422' }\end{array}$ & NP & 578 & NP & $\mathrm{NP}$ & NP & & & NP & 538 & NP & 40 & 40 & NP & $\mathrm{NP}$ & $\mathrm{NP}$ & NP & NP & $\mathrm{NP}$ & 346 & 36 & No faulting reported \\
\hline 699-56-43 & 0 & NP & 15 & NP & 53 & NP & 53 & NP & 65 & $\begin{array}{l}\text { Elephant } \\
\text { Mtn? }\end{array}$ & ? & 541 & NP & 526 & NP & 488 & $\mathrm{NP}$ & 488 & NP & 475.9 & 15 & 38 & NP & 38 & NP & 12 & NP & 12 & NP? & & & Switch to HT @53' \\
\hline 699-56-51 & 0 & 2 & NP & NP & $\mathrm{NP}$ & & & NP & 103 & $\begin{array}{c}\text { Elephant } \\
\text { Mtn? }\end{array}$ & & \begin{tabular}{|l|l|}
440.5 \\
\end{tabular} & 438.5 & NP & $\mathrm{NP}$ & $\mathrm{NP}$ & & & NP & 337.5 & 2 & 101 & 101 & NP & $\mathrm{NP}$ & $\mathrm{NP}$ & NP & NP & $\mathrm{NP}$ & & & Driller log mislabled well 699-56-50 \\
\hline 699-57-41A & 0 & 10 & NP & NP & $\mathrm{NP}$ & & & NP & 75 & Pomona? & $\begin{array}{l}\text { Selah }=250^{\prime}, \\
\text { Esquatzel = } \\
260, \\
\text { Asotin }= \\
329^{\prime}, \\
\text { unnamed } \\
\text { interbed }= \\
480^{\prime}\end{array}$ & 707 & 697 & NP & NP & NP & & & $\mathrm{NP}$ & 632 & 10 & 65 & 65 & NP & $\mathrm{NP}$ & $\mathrm{NP}$ & NP & NP & $\mathrm{NP}$ & NP & $\mathrm{NP}$ & $\begin{array}{l}\text { Fault zone @ } 395 \text { ' produces repeated } \\
\text { section? }\end{array}$ \\
\hline 699-57-41B & $\mathrm{NP}$ & 0 & NP & NP & NP & & & NP & 65 & Pomona? & $\begin{array}{l}\text { Selah }=203^{\prime}, \\
\text { Esquatzel }= \\
218^{\prime}, \text { Cold } \\
\text { Cr } \\
\text { Interbed = } \\
283^{\prime} \text {. } \\
\text { Asotin = } \\
302, \\
\text { unnamed } \\
\text { interbed = } \\
416, \\
\text { Umatilla = } \\
\text { 431' }\end{array}$ & NP & 711 & NP & NP & NP & & & $\mathrm{NP}$ & 646 & NP & 65 & 65 & NP & $\mathrm{NP}$ & $\mathrm{NP}$ & NP & NP & NP & $\mathrm{NP}$ & $\mathrm{NP}$ & \\
\hline
\end{tabular}


Table E.1. (contd)

\begin{tabular}{|c|c|c|c|c|c|c|c|c|c|c|c|c|c|c|c|c|c|c|c|c|c|c|c|c|c|c|c|c|c|c|c|c|}
\hline \multirow[b]{2}{*}{ Well Name } & \multicolumn{11}{|c|}{ Contact Depths (ft) } & \multicolumn{9}{|c|}{ Contact Elevations (ft) } & \multicolumn{11}{|c|}{ Thickness (ft) } & \multirow[b]{2}{*}{ Comments } \\
\hline & 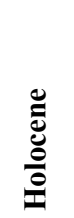 & 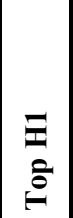 & 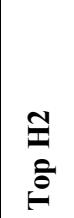 & $\begin{array}{l}m \\
0 \\
0 \\
0\end{array}$ & $\begin{array}{l}己 \\
0 \\
\tilde{O} \\
0 \\
0\end{array}$ & $\begin{array}{l}\tilde{U}^{N} \\
\tilde{a}\end{array}$ & 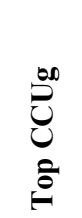 & 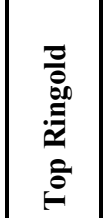 & ڤ̊ & 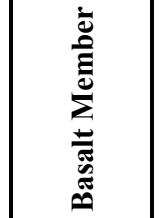 & 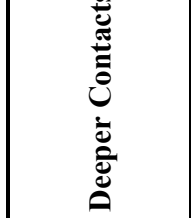 & 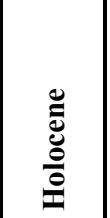 & $\begin{array}{l}\text { E } \\
\stackrel{\theta}{G}\end{array}$ & 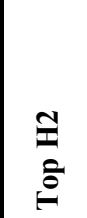 & 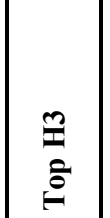 & $\begin{array}{l}己 \\
己 \\
\tilde{\Xi} \\
\tilde{\theta}\end{array}$ & $\begin{array}{l}\tilde{0} \\
0 \\
\tilde{Q} \\
\tilde{\theta}\end{array}$ & 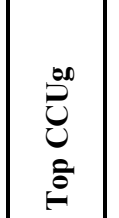 & 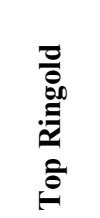 & $\stackrel{\infty}{0}$ & 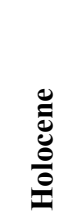 & 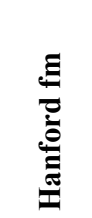 & $\Xi$ & $\cong$ & 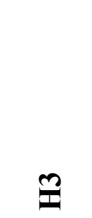 & 己 & 记 & $\overbrace{0}^{\infty}$ & 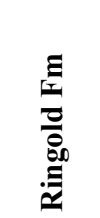 & 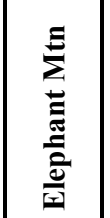 & 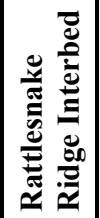 & \\
\hline \begin{tabular}{|l|}
$699-57-41 \mathrm{C}$ \\
\end{tabular} & $\mathrm{NP}$ & 0 & $\mathrm{NP}$ & $\mathrm{NP}$ & $\mathrm{NP}$ & & & $\mathrm{NP}$ & 123 & $\begin{array}{c}* \text { Window } \\
\text { into } \\
\text { Selah } \\
\text { Interbed }\end{array}$ & $\begin{array}{l}\text { Esquatzel }= \\
122^{\prime} \\
\text { Asotin }^{\prime}= \\
238^{\prime}\end{array}$ & $\mathrm{NP}$ & 709 & $\mathrm{NP}$ & $\mathrm{NP}$ & $\mathrm{NP}$ & & & $\mathrm{NP}$ & 586 & $\mathrm{NP}$ & 123 & 123 & $\mathrm{NP}$ & $\mathrm{NP}$ & $\mathrm{NP}$ & $\mathrm{NP}$ & $\mathrm{NP}$ & $\mathrm{NP}$ & $\mathrm{NP}$ & NP & \\
\hline 699-57-41E & $\mathrm{NP}$ & 0 & NP & NP & NP & & & NP & 35 & Pomona & & $\mathrm{NP}$ & 698 & NP & $\mathrm{NP}$ & NP & & & $\mathrm{NP}$ & 663 & NP & 35 & 35 & NP & $\mathrm{NP}$ & $\mathrm{NP}$ & $\mathrm{NP}$ & $\mathrm{NP}$ & $\mathrm{NP}$ & $\mathrm{NP}$ & $\mathrm{NP}$ & \\
\hline 699-57-41F & $\mathrm{NP}$ & 0 & NP & NP & NP & & & $\mathrm{NP}$ & 80 & Pomona & $\begin{array}{l}\text { Selah }=261, \\
\text { Esquatzel = } \\
272^{\prime}, \\
\text { Asotin = } \\
440^{\prime}\end{array}$ & $\mathrm{NP}$ & 708 & NP & $\mathrm{NP}$ & $\mathrm{NP}$ & & & $\mathrm{NP}$ & 628 & $\mathrm{NP}$ & 80 & 80 & NP & $\mathrm{NP}$ & $\mathrm{NP}$ & $\mathrm{NP}$ & $\mathrm{NP}$ & $\mathrm{NP}$ & $\mathrm{NP}$ & NP & $\begin{array}{l}\text { Fault zones 190-194.5', 220', } \\
\text { 335-357', 571-573 - repeated sections }\end{array}$ \\
\hline 699-57-59 & 0 & 1.5 & $\mathrm{NP}$ & NP & 154 & 154 & 158 & NP? & ETD & & & 576.5 & 575 & NP & $\mathrm{NP}$ & 423 & 423 & 419 & NP? & ETD & 1.5 & 152 & 152 & NP & $\mathrm{NP}$ & $>36$ & 4 & $>36 ?$ & NP? & & & \\
\hline 699-58-41A & 0 & $\mathrm{NP}$ & $\mathrm{NP}$ & NP & NP & & & NP & 15 & Pomona & & 710 & $\mathrm{NP}$ & NP & $\mathrm{NP}$ & $\mathrm{NP}$ & & & $\mathrm{NP}$ & 695 & 15 & $\mathrm{NP}$ & $\mathrm{NP}$ & NP & $\mathrm{NP}$ & $\mathrm{NP}$ & $\mathrm{NP}$ & $\mathrm{NP}$ & $\mathrm{NP}$ & $\mathrm{NP}$ & NP & $\begin{array}{l}15^{\prime} \text { loess over basalt; fault zone from } \\
110-185 \text { ' repeats section of Pomona } \\
\text { basalt }\end{array}$ \\
\hline 699-58-41B & 0 & 15 & NP & NP & $\mathrm{NP}$ & & & $\mathrm{NP}$ & 75 & Pomona & & 704 & 689 & NP & $\mathrm{NP}$ & $\mathrm{NP}$ & & & $\mathrm{NP}$ & 629 & 15 & 60 & 60 & NP & $\mathrm{NP}$ & $\mathrm{NP}$ & $\mathrm{NP}$ & NP & $\mathrm{NP}$ & $\mathrm{NP}$ & NP & $\begin{array}{l}\text { Fault zone from 155-195' repeats } \\
\text { section of Pomona basalt }\end{array}$ \\
\hline 699-58-41C & 0 & 15 & $\mathrm{NP}$ & NP & $\mathrm{NP}$ & & & $\mathrm{NP}$ & $80^{*}$ & $\begin{array}{r}\text { *Window } \\
\text { into RRI }\end{array}$ & $\begin{array}{l}\text { Pomona }= \\
96^{\prime}\end{array}$ & 703 & 688 & NP & $\mathrm{NP}$ & $\mathrm{NP}$ & & & $\mathrm{NP}$ & $623^{*}$ & 15 & 65 & 65 & NP & $\mathrm{NP}$ & $\mathrm{NP}$ & $\mathrm{NP}$ & $\mathrm{NP}$ & $\mathrm{NP}$ & $\mathrm{NP}$ & 16 & $\mathrm{TOB}=$ top RRI \\
\hline 699-58-41D & $\mathrm{NP}$ & 0 & NP & $\mathrm{NP}$ & $\mathrm{NP}$ & & & $\mathrm{NP}$ & 18 & $\begin{array}{c}\text { Elephant } \\
\text { Mtn }\end{array}$ & $\begin{array}{l}\mathrm{RRI}=49^{\prime}, \\
\text { Pomona }= \\
72^{\prime}\end{array}$ & $\mathrm{NP}$ & 702 & $\mathrm{NP}$ & $\mathrm{NP}$ & $\mathrm{NP}$ & & & $\mathrm{NP}$ & 684 & NP & 18 & 18 & NP & $\mathrm{NP}$ & $\mathrm{NP}$ & $\mathrm{NP}$ & $\mathrm{NP}$ & $\mathrm{NP}$ & 31 & 23 & \\
\hline 699-58-41E & 0 & $\mathrm{NP}$ & $\mathrm{NP}$ & NP & $\mathrm{NP}$ & & & $\mathrm{NP}$ & 10 & $\underset{\text { Mtn }}{\text { Elephant }}$ & $\begin{array}{l}\text { RRI }=50^{\prime}, \\
\text { Pomona }= \\
115^{\prime}, \text { Selah }= \\
345^{\prime}, \\
\text { Esquatzel = } \\
365^{\prime}\end{array}$ & 700 & $\mathrm{NP}$ & NP & NP & NP & & & $\mathrm{NP}$ & 690 & 10 & $\mathrm{NP}$ & $\mathrm{NP}$ & $\mathrm{NP}$ & $\mathrm{NP}$ & $\mathrm{NP}$ & $\mathrm{NP}$ & $\mathrm{NP}$ & $\mathrm{NP}$ & 40 & 65 & Fault zone 75-90' repeats RRI? \\
\hline 699-58-41F & 0 & 5 & NP & NP & $\mathrm{NP}$ & & & $\mathrm{NP}$ & 70 & Pomona & $\begin{array}{l}\text { Selah =248', } \\
\text { Esquatzel = } \\
390^{\prime}, \text { Cold } \\
\text { Cr } \\
\text { Interbed = } \\
492^{\prime}, \\
\text { Asotin = } \\
538^{\prime}\end{array}$ & 699.5 & 694.5 & $\mathrm{NP}$ & $\mathrm{NP}$ & $\mathrm{NP}$ & & & $\mathrm{NP}$ & 629.5 & 5 & 65 & 65 & NP & $\mathrm{NP}$ & $\mathrm{NP}$ & $\mathrm{NP}$ & $\mathrm{NP}$ & $\mathrm{NP}$ & $\mathrm{NP}$ & $\mathrm{NP}$ & $\begin{array}{l}\text { Fault zone at } 283^{\prime} \text { repeats } \\
\text { Selah/Pomona section }\end{array}$ \\
\hline 699-58-48 & $\mathrm{NP}$ & $\mathrm{NP}$ & NP & NP & NP & & & NP & 0 & & & NP & $\mathrm{NP}$ & $\mathrm{NP}$ & $\mathrm{NP}$ & $\mathrm{NP}$ & & & $\mathrm{NP}$ & $?$ & $\mathrm{NP}$ & $\mathrm{NP}$ & NP & $\mathrm{NP}$ & $\mathrm{NP}$ & $\mathrm{NP}$ & $\mathrm{NP}$ & $\mathrm{NP}$ & $\mathrm{NP}$ & & & CRB at surface \\
\hline $699-59-55$ & $\mathrm{NP}$ & 0 & NP & NP & NP? & & & $?$ & ETD & & & $\mathrm{NP}$ & 432 & $\mathrm{NP}$ & $\mathrm{NP}$ & NP? & & & $?$ & ETD & $\mathrm{NP}$ & $?$ & $?$ & NP & $\mathrm{NP}$ & $\mathrm{NP} ?$ & NP? & NP? & $\mathrm{NP}$ & & & $\begin{array}{l}\text { Drilling terminated prematurely } \\
\text { because of potential for cave in from } \\
\text { sand removal via air rotary drilling. }\end{array}$ \\
\hline 699-59-58 & $\mathrm{NP}$ & 0 & $\mathrm{NP}$ & NP & 92 & 92 & $\mathrm{NP}$ ? & NP? & ETD & & & $\mathrm{NP}$ & 499 & $\mathrm{NP}$ & $\mathrm{NP}$ & 407 & 407 & $\begin{array}{l}\text { ETD } \\
(379 ?)\end{array}$ & NP? & ETD & NP & 92 & 92 & NP & $\mathrm{NP}$ & $>25 ?$ & $\begin{array}{l}>25 \\
(28 ?)\end{array}$ & $\begin{array}{l}<140 \\
(129 ?)\end{array}$ & NP? & & & Uniform zS bed from 92-104' \\
\hline 699-60-53B & $\mathrm{NP}$ & $\mathrm{NP}$ & NP & $\mathrm{NP}$ & $\mathrm{NP}$ & & & $\mathrm{NP}$ & 0 & $\begin{array}{c}\text { Elephant } \\
\text { Mtn }\end{array}$ & $\begin{array}{l}\text { RRI }=78^{\prime}, \\
\text { Pomona 102' }\end{array}$ & NP & $\mathrm{NP}$ & $\mathrm{NP}$ & $\mathrm{NP}$ & $\mathrm{NP}$ & & & $\mathrm{NP}$ & ? & NP & $\mathrm{NP}$ & NP & NP & $\mathrm{NP}$ & $\mathrm{NP}$ & $\mathrm{NP}$ & NP & $\mathrm{NP}$ & 78 & 24 & Basalt at surface \\
\hline
\end{tabular}


Table E.1. (contd)

\begin{tabular}{|c|c|c|c|c|c|c|c|c|c|c|c|c|c|c|c|c|c|c|c|c|c|c|c|c|c|c|c|c|c|c|c|c|}
\hline \multirow[b]{2}{*}{ Well Name } & \multicolumn{11}{|c|}{ Contact Depths (ft) } & \multicolumn{9}{|c|}{ Contact Elevations (ft) } & \multicolumn{11}{|c|}{ Thickness (ft) } & \multirow[b]{2}{*}{ Comments } \\
\hline & 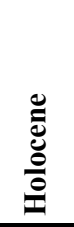 & \begin{tabular}{|l|}
$\Xi$ \\
0 \\
$\tilde{\theta}$ \\
\end{tabular} & \begin{tabular}{|l}
$\tilde{I}$ \\
$\tilde{E}$ \\
0 \\
\end{tabular} & 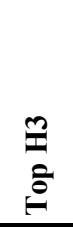 & $\begin{array}{l}0 \\
0 \\
0 \\
0 \\
\end{array}$ & $\begin{array}{l}0 \\
0 \\
0 \\
0 \\
0\end{array}$ & $\begin{array}{l}\underbrace{\infty}_{0} \\
0 \\
0 \\
0\end{array}$ & 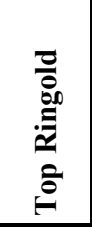 & है & 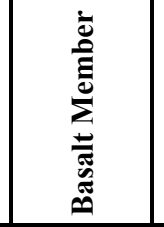 & 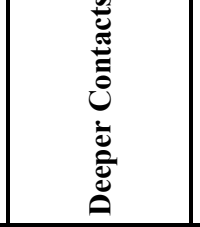 & 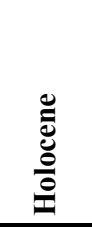 & $\begin{array}{l} \pm \\
\bar{g} \\
\bar{E}\end{array}$ & 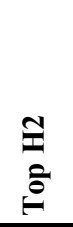 & $\begin{array}{l}\frac{m}{\nexists} \\
0 \\
0 \\
0\end{array}$ & $\begin{array}{l}己 \\
U \\
\tilde{\theta} \\
\tilde{\theta}\end{array}$ & $\begin{array}{l}0 \\
0 \\
0 \\
0 \\
0\end{array}$ & $\begin{array}{l}\underbrace{\infty}_{0} \\
0 \\
0 \\
0\end{array}$ & 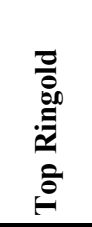 & है & 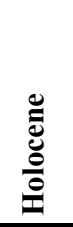 & 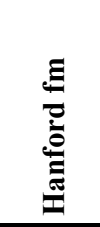 & $\Xi$ & $\mathfrak{I}$ & 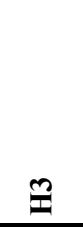 & 己 & 己्己 & $\mathbb{U}^{\infty}$ & 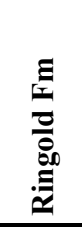 & 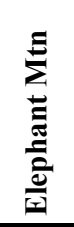 & 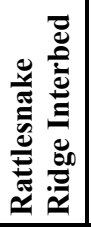 & \\
\hline 699-60-53C & $\mathrm{NP}$ & NP & $\mathrm{NP}$ & NP & NP & & & $\mathrm{NP}$ & 0 & $\begin{array}{c}\text { Elephant } \\
\text { Mtn }\end{array}$ & $\begin{array}{l}\text { RRI = 77', } \\
\text { Pomona = } \\
102^{\prime}\end{array}$ & $\mathrm{NP}$ & $\mathrm{NP}$ & $\mathrm{NP}$ & $\mathrm{NP}$ & $\mathrm{NP}$ & & & $\mathrm{NP}$ & $?$ & $\mathrm{NP}$ & $\mathrm{NP}$ & $\mathrm{NP}$ & $\mathrm{NP}$ & $\mathrm{NP}$ & $\mathrm{NP}$ & $\mathrm{NP}$ & $\mathrm{NP}$ & $\mathrm{NP}$ & 77 & 25 & Basalt at surface \\
\hline 699-60-53F & $\mathrm{NP}$ & NP & NP & NP & NP & & & $\mathrm{NP}$ & 0 & $\begin{array}{c}\text { Elephant } \\
\text { Mtn }\end{array}$ & $\begin{array}{l}\text { RRI }=76 \text { ', } \\
\text { Pomona = } \\
\text { 100', Selah }= \\
286^{\prime}\end{array}$ & $\mathrm{NP}$ & $\mathrm{NP}$ & $\mathrm{NP}$ & $\mathrm{NP}$ & NP & & & NP & 821 & $\mathrm{NP}$ & $\mathrm{NP}$ & NP & NP & NP & NP & NP & NP & NP & 76 & 24 & Basalt at surface \\
\hline 699-60-57 & $\mathrm{NP}$ & 0 & NP & NP & NP & & & 133 & 145 & Asotin & & $\mathrm{NP}$ & 471 & $\mathrm{NP}$ & NP & $\mathrm{NP}$ & & & 338 & 326 & NP & 133 & 125 & 8 & $\mathrm{NP}$ & NP & $\mathrm{NP}$ & NP & 12 & $\mathrm{NP}$ & $\mathrm{NP}$ & \\
\hline 699-60-59 & $\mathrm{NP}$ & 0 & $\mathrm{NP}$ & $\mathrm{NP}$ & $\mathrm{NP}$ & & & $\mathrm{NP}$ & 180 & Asotin & $\begin{array}{l}\text { Umatilla }= \\
2221^{\prime} \\
\text { Mabton }= \\
462^{\prime}, \text { Priest } \\
\text { Rapids }= \\
574^{\prime}\end{array}$ & $\mathrm{NP}$ & 509 & $\mathrm{NP}$ & $\mathrm{NP}$ & NP & & & $\mathrm{NP}$ & 329 & $\mathrm{NP}$ & 180 & 180 & $\mathrm{NP}$ & $\mathrm{NP}$ & $\mathrm{NP}$ & $\mathrm{NP}$ & $\mathrm{NP}$ & $\mathrm{NP}$ & $\mathrm{NP}$ & $\mathrm{NP}$ & \\
\hline 699-60-60 & $\mathrm{NP}$ & 0 & NP & NP & NP & & & $\mathrm{NP}$ & 128 & Esquatzel & & $\mathrm{NP}$ & 513 & $\mathrm{NP}$ & $\mathrm{NP}$ & NP & & & $\mathrm{NP}$ & 385 & $\mathrm{NP}$ & 128 & 128 & NP & NP & $\mathrm{NP}$ & NP & NP & NP & $\mathrm{NP}$ & NP & \\
\hline 699-61-53 & $\mathrm{NP}$ & NP & NP & NP & NP & & & $\mathrm{NP}$ & 0 & $\begin{array}{c}\text { Elephant } \\
\text { Mtn }\end{array}$ & $\begin{array}{l}\text { RRI }=76^{\prime}, \\
\text { Pomona }= \\
96^{\prime}, \text { Selah }= \\
278^{\prime}, \\
\text { Esquatzel }= \\
295^{\prime}, \\
\text { Asotin }= \\
362^{\prime}\end{array}$ & $\mathrm{NP}$ & $\mathrm{NP}$ & $\mathrm{NP}$ & $\mathrm{NP}$ & NP & & & NP & 765 & $\mathrm{NP}$ & $\mathrm{NP}$ & NP & NP & $\mathrm{NP}$ & $\mathrm{NP}$ & $\mathrm{NP}$ & $\mathrm{NP}$ & $\mathrm{NP}$ & 76 & 20 & On Gable Mtn, basalt at surface \\
\hline 699-61-55A & $\mathrm{NP}$ & NP & NP & NP & NP & & & $\mathrm{NP}$ & 0 & Asotin & $\begin{array}{l}\text { Unnamed } \\
\text { Interbed }= \\
69^{\prime}, \\
\text { Umatilla }= \\
71^{\prime}, \\
\text { Mabton }= \\
223^{\prime}\end{array}$ & $\mathrm{NP}$ & $\mathrm{NP}$ & $\mathrm{NP}$ & NP & NP & & & $\mathrm{NP}$ & 463.0 & $\mathrm{NP}$ & $\mathrm{NP}$ & NP & NP & NP & $\mathrm{NP}$ & NP & NP & NP & NP & $\mathrm{NP}$ & \\
\hline 699-61-55B & $\mathrm{NP}$ & NP & NP & NP & NP & & & $\mathrm{NP}$ & 0 & Asotin & $\begin{array}{l}\text { Umatilla = } \\
60^{\prime} \\
\text { Mabton }= \\
218^{\prime}, \text { Priest } \\
\text { Rapids }= \\
326^{\prime}\end{array}$ & $\mathrm{NP}$ & NP & $\mathrm{NP}$ & NP & NP & & & NP & 464 & $\mathrm{NP}$ & $\mathrm{NP}$ & $\mathrm{NP}$ & NP & NP & $\mathrm{NP}$ & NP & NP & NP & NP & $\mathrm{NP}$ & \\
\hline 699-61-57 & $\mathrm{NP}$ & $\mathrm{NP}$ & $\mathrm{NP}$ & $\mathrm{NP}$ & $\mathrm{NP}$ & & & $\mathrm{NP}$ & 0 & Pomona & $\begin{array}{l}\text { Selah = 121', } \\
\text { Esquatzel = } \\
150^{\prime} \\
\text { Asotin = } \\
249^{\prime}, \text { Cold } \\
\text { Creek = 330, } \\
\text { Umatilla = } \\
337^{\prime}, \\
\text { Mabton = } \\
503^{\prime}\end{array}$ & $\mathrm{NP}$ & $\mathrm{NP}$ & $\mathrm{NP}$ & $\mathrm{NP}$ & $\mathrm{NP}$ & & & NP & 444 & $\mathrm{NP}$ & $\mathrm{NP}$ & NP & $\mathrm{NP}$ & $\mathrm{NP}$ & $\mathrm{NP}$ & NP & $\mathrm{NP}$ & NP & $\mathrm{NP}$ & $\mathrm{NP}$ & \\
\hline 699-61-62 & 0 & 2 & NP & NP & $\mathrm{NP}$ & & & $115 ?$ & 177.5 & Umatilla & & 498 & 496 & $\mathrm{NP}$ & $\mathrm{NP}$ & $\mathrm{NP}$ & & & $383 ?$ & 320 & 2 & $113 ?$ & $113 ?$ & NP & $\mathrm{NP}$ & NP & $\mathrm{NP}$ & NP & $63 ?$ & $\mathrm{NP}$ & NP & \\
\hline
\end{tabular}


Table E.1. (contd)

\begin{tabular}{|c|c|c|c|c|c|c|c|c|c|c|c|c|c|c|c|c|c|c|c|c|c|c|c|c|c|c|c|c|c|c|c|c|}
\hline \multirow[b]{2}{*}{ Well Name } & \multicolumn{11}{|c|}{ Contact Depths (ft) } & \multicolumn{9}{|c|}{ Contact Elevations (ft) } & \multicolumn{11}{|c|}{ Thickness (ft) } & \multirow[b]{2}{*}{ Comments } \\
\hline & 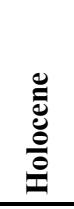 & \begin{tabular}{|l}
$E$ \\
$\vdots$ \\
$E$ \\
\end{tabular} & $\begin{array}{l}\tilde{I} \\
\tilde{E} \\
0\end{array}$ & 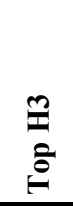 & $\begin{array}{l}己 \\
0 \\
o \\
\theta \\
\theta\end{array}$ & 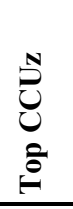 & 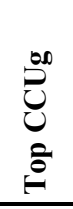 & 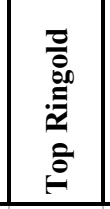 & $\stackrel{\tilde{0}}{\hat{\theta}}$ & 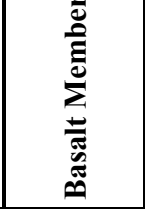 & 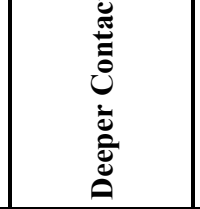 & 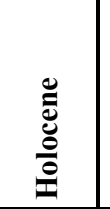 & 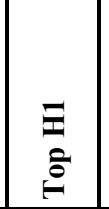 & $\begin{array}{l}\mathbf{I} \\
\bar{a} \\
\vdots \\
\vdots\end{array}$ & 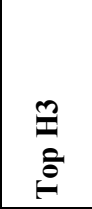 & $\begin{array}{l}己 \\
U \\
\tilde{\theta} \\
\tilde{\theta}\end{array}$ & $\begin{array}{l}0 \\
0 \\
0 \\
\tilde{a}\end{array}$ & $\begin{array}{l}\overbrace{0}^{\infty} \\
\tilde{\Xi} \\
\tilde{\theta}\end{array}$ & 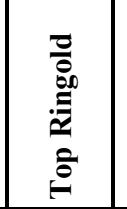 & $\stackrel{0}{0}$ & 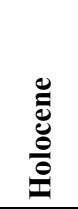 & 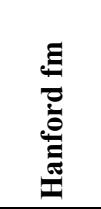 & $\Xi$ & $\tilde{I}$ & $\cong$ & Z्U & 己 & $\overbrace{0}^{\infty}$ & 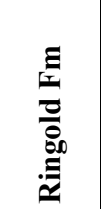 & 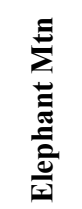 & 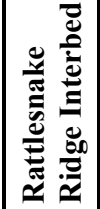 & \\
\hline 699-61-66 & $\mathrm{NP}$ & 0 & $\mathrm{NP}$ & $\mathrm{NP}$ & $\mathrm{NP}$ & & & $140 ?$ & 216.5 & Umatilla & & $\mathrm{NP}$ & 524 & $\mathrm{NP}$ & $\mathrm{NP}$ & $\mathrm{NP}$ & & & $384 ?$ & \begin{tabular}{|c|}
307.4 \\
\end{tabular} & $\mathrm{NP}$ & $140 ?$ & $140 ?$ & $\mathrm{NP}$ & $\mathrm{NP}$ & $\mathrm{NP}$ & $\mathrm{NP}$ & $\mathrm{NP}$ & $77 ?$ & $\mathrm{NP}$ & $\mathrm{NP}$ & Increase in $\mathrm{CaCO}_{3}+$ mud @140' \\
\hline 699-62-43B & 0 & 5 & NP & $\mathrm{NP}$ & $\mathrm{NP}$ & & & 65 & ETD & & & 422 & 417 & NP & NP & NP & & & 357 & ETD & 5 & 65 & 65 & NP & NP & NP & $\mathrm{NP}$ & $\mathrm{NP}$ & $>3$ & & & \\
\hline 699-62-53 & $\mathrm{NP}$ & 0 & NP & $\mathrm{NP}$ & $\mathrm{NP}$ & & & $\mathrm{NP}$ & 26 & $\begin{array}{l}\text { Elephant } \\
\text { Mtn }\end{array}$ & $\begin{array}{l}\text { RRI }=56 \text {, } \\
\text { Pomona }= \\
124^{\prime}, \text { Selah }= \\
298^{\prime}, \\
\text { Esquatzel= } \\
340^{\prime}\end{array}$ & NP & 439 & $\mathrm{NP}$ & NP & NP & & & $\mathrm{NP}$ & 413 & $\mathrm{NP}$ & 26 & 26 & NP & $\mathrm{NP}$ & $\mathrm{NP}$ & NP & $\mathrm{NP}$ & $\mathrm{NP}$ & 30 & 68 & $\begin{array}{l}\text { Drilled } \sim 30 \text { degrees from vertical - } \\
\text { therefore true depths are different }\end{array}$ \\
\hline 699-63-51 & 0 & 2 & NP & NP & NP & & & 20 & ETD & & & 425 & 423 & NP & $\mathrm{NP}$ & $\mathrm{NP}$ & & & 405 & ETD & 2 & 18 & 18 & NP & $\mathrm{NP}$ & $\mathrm{NP}$ & NP & $\mathrm{NP}$ & ? & & & Ringold lower mud @25"? \\
\hline 699-63-55 & $\mathrm{NP}$ & 0 & NP & $\mathrm{NP}$ & $\mathrm{NP}$ & & & NP? & $112 *$ & $\begin{array}{l}\text { *Window } \\
\text { into RRI }\end{array}$ & $\begin{array}{l}\text { RRI }=70, \\
\text { Pomona }= \\
112^{\prime}\end{array}$ & NP & 427.1 & NP & $\mathrm{NP}$ & NP & & & $\mathrm{NP} ?$ & $357^{*}$ & 0 & 68 & 68 & $\mathrm{NP}$ & $\mathrm{NP}$ & $\mathrm{NP}$ & $\mathrm{NP}$ & NP? & NP & $\mathrm{NP}$ & 42 & Changed from DB to HT @70' \\
\hline 699-63-58 & 0 & 2 & NP & NP & NP & & & NP & 120 & Pomona & & 493 & 491 & NP & NP & NP & & & $\mathrm{NP}$ & 373 & 2 & 118 & 118 & NP & NP & $\mathrm{NP}$ & NP & NP & NP & NP & $\mathrm{NP}$ & \\
\hline 699-64-62 & $\mathrm{NP}$ & 0 & NP & NP & $\mathrm{NP}$ & & & $90 ?$ & ETD & & & $\mathrm{NP}$ & 501 & NP & $\mathrm{NP}$ & $\mathrm{NP}$ & & & $411 ?$ & ETD & NP & $90 ?$ & $90 ?$ & NP & NP & $\mathrm{NP}$ & NP & $\mathrm{NP}$ & ? & & & \\
\hline 699-65-50 & 0 & 40 & NP & $\mathrm{NP}$ & $\mathrm{NP}$ & & & $102 ?$ & 578 & $\begin{array}{l}\text { Elephant } \\
\text { Mtn }\end{array}$ & & 469 & 429 & $\mathrm{NP}$ & NP & NP & & & $367 ?$ & -109 & 40 & $62 ?$ & $62 ?$ & NP & $\mathrm{NP}$ & $\mathrm{NP}$ & NP & $\mathrm{NP}$ & $476 ?$ & & & $\begin{array}{l}\mathrm{TOR}=\mathrm{LM} @ 105, \text { TOR could be as } \\
\text { high as 60' }\end{array}$ \\
\hline 699-65-59A & 0 & 2 & NP & $\mathrm{NP}$ & NP & & & $108 ?$ & ETD & & & 508.5 & 506.5 & $\mathrm{NP}$ & NP & NP & & & $400.5 ?$ & ETD & 2 & $106 ?$ & $106 ?$ & NP & $\mathrm{NP}$ & NP & NP & NP & ? & & & Ringold LM @200' \\
\hline 699-65-59B & NP & 0 & NP & $\mathrm{NP}$ & NP & & & $95 ?$ & ETD & & & NP & 507.6 & $\mathrm{NP}$ & $\mathrm{NP}$ & NP & & & $413 ?$ & ETD & NP & $95 ?$ & $95 ?$ & NP & NP & $\mathrm{NP}$ & NP & NP & $?$ & & & Decommissioned in 1995 \\
\hline 699-65-59C & $\mathrm{NP}$ & 0 & NP & NP & NP & & & $105 ?$ & ETD & & & $\mathrm{NP}$ & 506.1 & $\mathrm{NP}$ & NP & NP & & & $401 ?$ & ETD & NP & $105 ?$ & $105 ?$ & NP & $\mathrm{NP}$ & $\mathrm{NP}$ & NP & NP & $?$ & & & \\
\hline 699-65-72 & $?$ & $?$ & $?$ & $\mathrm{NP}$ & $?$ & $?$ & $?$ & ? & $?$ & & & ? & ? & $?$ & NP & $?$ & & & $?$ & ? & $?$ & ? & ? & $?$ & $\mathrm{NP}$ & $?$ & $?$ & ? & ? & & & \\
\hline 699-66-64 & NP & 0 & NP & NP & NP & & & $\underline{\underline{?}}$ & ETD & & & NP & 506.7 & $\mathrm{NP}$ & $\mathrm{NP}$ & NP & & & $\underline{?}$ & ETD & $\mathrm{NP}$ & ? & ? & $\mathrm{NP}$ & NP & $\mathrm{NP}$ & NP & $\mathrm{NP}$ & $?$ & & & \\
\hline 699-67-51 & $\mathrm{NP}$ & 0 & NP & NP & NP & $\mathrm{NP}$ & $\mathrm{NP}$ & 145 & ETD & & & $\mathrm{NP}$ & 525 & $\mathrm{NP}$ & $\mathrm{NP}$ & NP & $\mathrm{NP}$ & $\mathrm{NP}$ & 380 & ETD & NP & 145 & 145 & NP & $\mathrm{NP}$ & $\mathrm{NP}$ & NP & NP & $>105$ & & & \\
\hline 699-69-45 & 0 & 5 & & $\mathrm{NP}$ & NP & & & 90 & ETD & & & 488 & 483 & $\mathrm{NP}$ & NP & NP & & & 398 & ETD & 5 & 85 & 85 & NP & NP & NP & $\mathrm{NP}$ & $\mathrm{NP}$ & $>210$ & & & \\
\hline 699-70-68 & NP & 0 & NP & NP & NP & & & $50 ?$ & ETD & & & NP & 527 & $\mathrm{NP}$ & NP & NP & & & $477 ?$ & ETD & $\mathrm{NP}$ & $50 ?$ & $50 ?$ & NP & NP & $\mathrm{NP}$ & NP & $\mathrm{NP}$ & ? & & & \\
\hline 699-71-52 & 0 & 3 & NP & NP & NP & & & 120 & ETD & & & 525 & 522 & NP & NP & NP & & & 405 & ETD & 3 & 117 & 117 & NP & NP & NP & NP & NP & $>90$ & & & \\
\hline 699-72-73 & $\mathrm{NP}$ & 0 & NP & $\mathrm{NP}$ & $\mathrm{NP}$ & & & $90 ?$ & ETD & & & NP & 483.5 & $\mathrm{NP}$ & NP & NP & & & 393.5? & ETD & $\mathrm{NP}$ & $90 ?$ & $90 ?$ & NP & $\mathrm{NP}$ & $\mathrm{NP}$ & $\mathrm{NP}$ & $\mathrm{NP}$ & $>110$ & & & $\begin{array}{l}\text { Cemented starting @ } 90 \text { ', Ringold LM } \\
@ 170^{\prime}\end{array}$ \\
\hline 699-73-61 & $\mathrm{NP}$ & 0 & NP & $\mathrm{NP}$ & $\mathrm{NP}$ & & & $120 ?$ & ETD & & & $\mathrm{NP}$ & 533 & $\mathrm{NP}$ & NP & $\mathrm{NP}$ & & & $413 ?$ & ETD & $\mathrm{NP}$ & $120 ?$ & $120 ?$ & $\mathrm{NP}$ & $\mathrm{NP}$ & $\mathrm{NP}$ & $\mathrm{NP}$ & NP & $?$ & & & $\begin{array}{l}\text { Color change from gray to tan/brown } \\
\text { @ } 120^{\prime}\end{array}$ \\
\hline
\end{tabular}




\section{Distribution}

No. of

Copies

\section{OFFSITE}

SP Airhart

Freestone Environmental Services

1100 Jadwin Avenue \#250

Richland, WA 99352-3425

P Cabbage

Freestone Environmental Services

1100 Jadwin Avenue \#250

Richland, WA 99352-3425

JL Ludwig

Intera, Inc.

1933 Jadwin Avenue \#130

Richland, WA 99354-2280

\section{ONSITE}

\section{DOE Richland Operations Office}

JP Hanson

RD Hildebrand

KM Thompson
No. of

\section{Copies}

15 CH2M HILL Plateau Remediation

\section{Company}

AH Aly

H8-51

GD Cummins

$\mathrm{H} 8-15$

BH Ford

$\mathrm{H} 8-43$

GG Kelty

R3-50

SP Luttrell

R3 -50

JP McDonald

R3-50

SD Miller

$\mathrm{H} 8-51$

WE Nichols

H8-51

VJ Rohay

H8-15

LC Swanson

R3-50

GS Thomas

R3-50

MD Thompson

$\mathrm{H} 8-51$

LD Walker

$\mathrm{K} 3-60$

WD Webber

$\mathrm{H} 8-51$

BA Williams

$\mathrm{H} 8-51$

16 Pacific Northwest National Laboratory

BN Bjornstad (5) K6-81

CF Brown K6-81

MA Chamness K6-85

TJ Gilmore K6-96

JA Horner K6-96

DC Lanigan K6-75

GV Last K6-81

RE Peterson K6-75

RJ Serne K6-81

FA Spane K6-96

C Sullivan K6-81

PD Thorne K6-96 


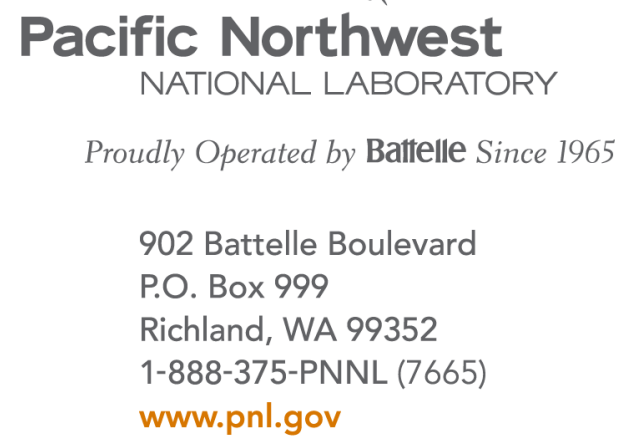

Pacific Northwest

NATIONAL LABORATORY

Proudly Operated by Battelle Since 1965

902 Battelle Boulevard

P.O. Box 999

Richland, WA 99352

1-888-375-PNNL (7665)

www.pnl.gov 